\title{
THE WHITE SETTLER COLONIAL LANDSCAPE OF TORONTO'S WYCHWOOD
} PARK

by

\author{
Emily R.M. Lind
}

A thesis submitted to the Faculty of Graduate and Postdoctoral Affairs in partial fulfillment of the requirements for the degree of

Doctor of Philosophy

in

CULTURAL MEDIATIONS

Carleton University
Ottawa Ontario

C 2020 Emily R.M. Lind 


\begin{abstract}
Mythologized as a former artist's colony, Wychwood Park is a gated community in midtown Toronto that encompasses fifty-eight homes built at the turn of the twentieth century. Wychwood Park's landscape plan is one of Canada's earliest examples of a garden suburb - a suburban design model derived from the turn-of-the-twentieth-century English Garden City movement. The Park boasts the highest concentration of Arts and Crafts domestic architecture in Toronto. Famous early residents included artists and art patrons who were instrumental in establishing what became the Art Gallery of Ontario, the Royal Ontario Museum, the Ontario College of Art and Design, and the Ontario Society of Artists.
\end{abstract}

In this dissertation, I argue that Wychwood Park is a white settler colonial landscape. This argument is informed by the idea of landscape as an actor in social and political processes, rather than a reflection of them. The physical landscape of Wychwood Park, and the extent to which it reflects the ideas and values that sustain settler colonial rule, are seriously interrogated in this project. I am interested in the ways that a neighbourhood like Wychwood Park can teach Torontonians something about how patriarchy and racism work and what it means to live in an environment shaped by gendered/racialized thinking and social organization. I am informed by Richard Schein's contentions that "discourses of racialized social relations work through landscapes" that landscapes are the sites in which racialized discourses become "materialized." In this

\footnotetext{
${ }^{1}$ Richard Schein, "A Methodological Framework for Interpreting Ordinary Landscapes: Lexington, Kentucky's Courthouse Square," Geographical Review 99, no. 3 (2009): 396.

2 Richard Schein, "The Place of Landscape: A Conceptual Framework for Interpreting an American Scene," Annals of the Association of American Geographers 87, no. 4 (1997): 666.
} 
dissertation, I situate the patriarchal and racialized social relations of settler colonialism within the material landscape of Wychwood Park. This approach highlights Wychwood Park's engagement with the settler colonial project, addressing a gap in existing literature on the Park specifically and on Toronto history as a whole. 


\section{Dedication}

For Christopher and Sophia 


\section{Acknowledgments}

Completing this degree took nearly thirteen years, and in that time I was encouraged and mentored by countless people - many of whom are still in my life, some of whom are not. My sincere gratitude to my former partner, Michael Franklin, who listened enthusiastically and lovingly through countless iterations of the ideas that finally took shape in this thesis. My former best friend, Claire L. Carter, was similarly unrelenting in her belief in my talent and promise as a scholar. I carry both of their love with me always.

I was accompanied by fabulous colleagues and friends in Cultural Mediations, and the long conversations, cheap beer, and seminar workshops I shared with Egemen Ozbek, Jason Green, Owen Lyons, Nicholette Prince, and Bianca Briciu broke the isolation of graduate study and moved my thinking in directions I wouldn't have encountered otherwise. Helin Burkay also became a cherished friend and I continue to learn from her every time we speak. I am grateful for the opportunity to have learned from Ruth Phillips, Jill Carrick, Barbara Leckie, Franny Nudelman, Marc Furstenau, Mark Phillips, Brian Foss, Jennifer Henderson, Mitchell Frank, Justin Paulson, and Pamela Walker. Dawn Schmidt was invaluable as an ally and departmental champion for my success.

I began my first year at Carleton in 2008, at the height of what is now referred to as the great recession. By the end of that first academic year TAs lost protective language in their collective agreement that capped tuition rates. Subsequently, my tuition rose to the maximum legal limit each year, while my wages were frozen under provinciallymandated austerity restrictions. I want to acknowledge the thankless work of CUPE 4600 members and staff who together served as the most significant voice on campus advocating for education as a right and a living wage for students. In particular I want to acknowledge Stuart Ryan, Leanne Parrish, Pierre Beaulieu-Blais and Dan Sawyer for working hard to protect the integrity of my collective agreement. I am so happy that union organizing introduced me to Priscillia Lefebvre and Robyn Green, two badass women I couldn't imagine life without.

I would like to acknowledge support from the Social Sciences and Humanities Research Council and the Ontario Graduate Scholarship Program for financial assistance in completing my degree. It was a big honour to receive these scholarships but I think the sector would be better served if government funding was redistributed to lower everyone's tuition rather than ranking us against each other and promoting elitist rituals of distinction among folks who have to take on debt anyway.

On the long road to completion countless friends treated me to dinner, let me crash on their couch, listened to me theorize poorly in circuitous loops, and pretended not to notice as the years went by and I still hadn't graduated. Allyson Marsolais, Stefanie Hurst, Adrienne Gruber, Brecken Hancock, Liz Nelson, Stefan van Doorn, Rosa Kouri, Liz Majic, and Matthew J. Trafford offered comfort in the storm and kept the smile on my face. Thank you, I love you.

Andrea Flowers and Michael Hodgins opened their house to me and loved me like family for several of the years I thought I was on the cusp of finishing. They cut my rent by half, gave me an extra room as a home office, and were always keenly interested to hear my progress. Living with them included some of my happiest years. Saqib and Andy 
Ali similarly adopted me in Ottawa and fed me more meals than I can count. They continue to be some of the best people I have ever known.

As I was completing my research Victoria Freeman, Phil Macintosh, Alla Myzelev, and Peter Goheen gave generously of their time to discuss archives related to Wychwood Park and the settler colonial history of Toronto at length. Their assistance and insights were invaluable and had major impacts on my work, particularly Victoria Freeman and Phil Macintosh, whose own dissertations I read in full, several times. Their work continues to be essential reading for me.

I am grateful to the staff of the Toronto Land Records Office, who helped me locate the earliest land transactions in Wychwood Park following colonial alienation. Staff at the Archives of Ontario, and the Toronto City Archives, particularly Lawrence Lee, were endlessly patient as I sifted and re-sifted through boxes of maps, Wychwood ephemera, and census data. Neil McFadyen forgave what was probably hundreds if not thousands of dollars of library fines without judgment. His grace allowed me to keep reading, be forgiven for my disorganization, and during personal crisis, forget about my obligations altogether.

In the spring of 2018, Peter Hodgins signed on to become my supervisor at a time when I was at my most fragile and disaffected. Not only did he believe in the work, he compelled me to believe in myself, and assembled a stellar dissertation committee who reinvigorated my thinking and gave me the tools to reshape this thesis into the document it is today. I will be forever grateful for his smarts, his wit, his emotional intelligence, and mentorship. David Hugill brought an encyclopedic knowledge of settler colonial studies and urban landscapes, and read my dissertation with generous precision. I have never met anyone whose every reading recommendation is perfect, but his always were. Peter Thompson was a strong ally of the thesis, playfully supporting "team Marmaduke" through the process, and I am grateful for his efficiency, professionalism, and camaraderie.

I am profoundly grateful for Ann Cvetkovich and Audrey Kobayashi who served as my external examiners. Their feedback was rigorous, exciting, and encouraging. I am eager to apply their suggestions in future iterations of this work.

For years, Mark Phillips served as an unofficial mentor as I worked to learn a new field of study and deepened my intellectual practice. He excelled at asking deep questions with sincere curiosity and holding space the size of a "Northrup Frye silence" until the answers came. We worked in vastly different fields, and had very little in common, but he gifted me with training in how to think and how to be that I will never forget. It is impossible for me to overstate the impact he had on this work; his mark is on almost every page.

Samantha Cutrara re-emerged front and centre in my life midway through this degree as a staunch ally, project management wizard, and confidante who is always, always right. I could not have done this without her.

May Friedman supported me in indescribable ways; she became my home away from home, mentored me, deferred to me, listened to the same anxiety over and over and acted as though I deserved steadfast love and grace even when no one else could possibly have. Not only did she believe in every word and iteration of every draft, she refused to let me give up, and included me in her own emerging research that brought me back to life when I was ready to leave the academy and not look back. I am so lucky to be a part 
of her family. Thank you to Dan, Noah, Molly, Izzy, Sasha and Sabrina for counting me among your own.

The love of aunties and uncles carried me through the drudgery of writing. Deep love and thanks to Marilyn Musgrove and Gord Jones, Tim Elliott and Judy Maddren, Peter Elliott and Thomas Roach.

I want to acknowledge my biggest fan, my mom, Heather Musgrove, for reading and copy editing every single draft of this dissertation. She never doubted I would finish, kept reminding me of everyone who took far longer, and never fails to tell me how proud she is of me. I am very lucky to have her in my corner. She and my stepdad, Rene Roy, fed me, housed me, and asked eager questions for years as I finished. Thanks to my brother, Aaron, for keeping me laughing. My stepmom, Anne Elliott, encouraged me to finish and provided me with significant material help towards that goal. She reminded me often that it was my Dad's biggest priority to ensure I would finish.

One of the joys of graduate school was the experience of sharing it with my father. We became incredibly close as I began my $\mathrm{PhD}$ and he delighted in sharing every new insight, book recommendation, department politic, and conference possibility with me. He was a brilliant scholar in his own right and we were both looking forward to collaborating on future projects together. I had no idea how lucky I was to have a Dad like that. I had no idea how lonely it would feel to engage in intellectual work without his wise and dynamic sounding board. Over the last few years, very special friends of his have stepped up to serve as ambassadors of his love and wisdom. I am deeply grateful to Pat Thompson, Barbara and Brian Ruttan, Esther Cherland, Deborah Tregunno, and the Guncles for meeting me in that 'thin place' where the magic happens.

When he died, it was unthinkable that he wouldn't read this thesis, or see me graduate. And I can't say that I am the same person I was when he died, which may be what allowed me to keep going. But the stubborn hope, the endless plodding, and the commitment to a meaningful idea despite its inconvenience - these are the values that help me live out what it means to be his daughter. This final draft is a love letter to him. 


\section{Table of Contents}

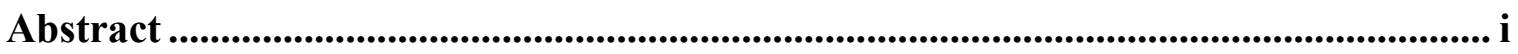

Dedication......................................................................................................................................... iii

Acknowledgments .............................................................................................................................. iv

Table of Contents............................................................................................................... vii

List of Figures ............................................................................................................................... $\mathrm{x}$

Prologue Notes from My Research Journal............................................................................ 1

Chapter One Wychwood Park as a White Settler Colonial Landscape......................... 2

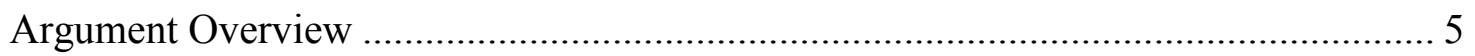

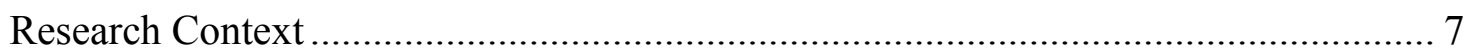

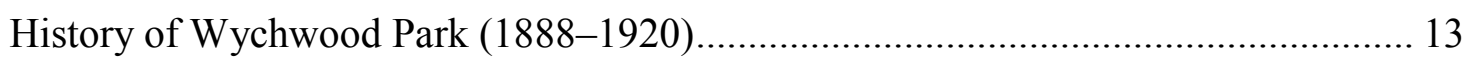

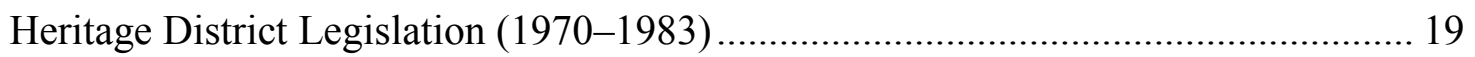

Building a Usable Past: Recent Wychwood Park History (1980s and 1990s) ............ 23

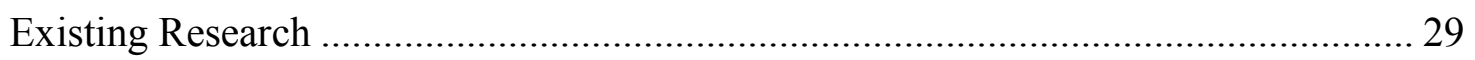

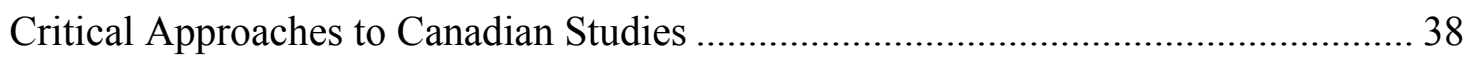

Plan of Dissertation: Elimination, Indigenization, Transcendence .............................. 42

Chapter Two: Research Method and Conceptual Framework .................................. 46

Chapter Three: Indigenous Elimination.............................................................. 47

Chapters Four and Five: Settler Indigenization ................................................... 48

Chapter Six: Colonial Transcendence................................................................. 50

Chapter Two Research Method \& Conceptual Framework ............................................ 54

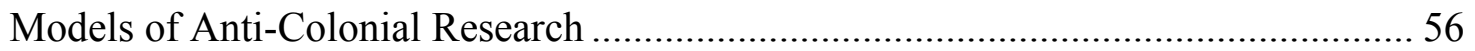

Anti-Colonial Research Methods in the Humanities .................................................. 59

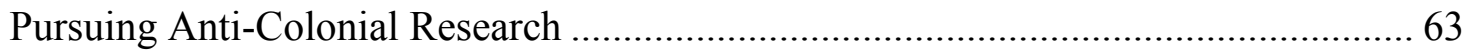

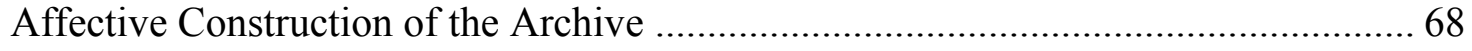

Conceptual Framework: Racialized Landscapes ....................................................... 73

Critical Landscape Studies........................................................................... 73

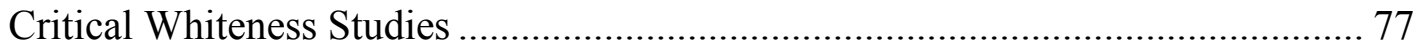


Chapter Three Indigenous Elimination: Historical Context for the Development of Wychwood Park: Private Property, Settler Space, and the History of Nineteenth-

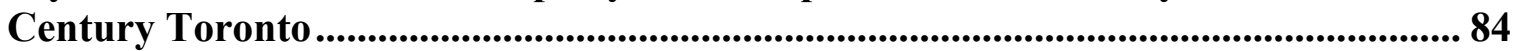

The Toronto Carrying Place as Multinational Homeland.......................................... 87

From Middle Ground to Divided Ground.................................................................. 92

The Context for Creating Private Property Out of Indigenous Land......................... 94

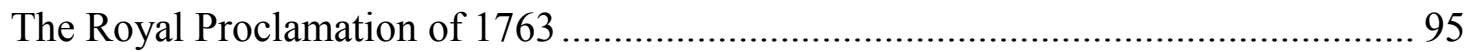

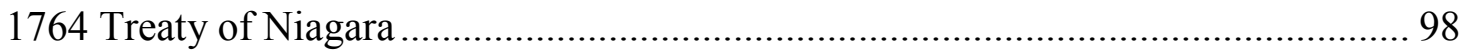

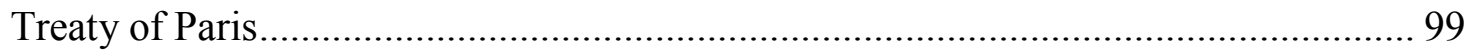

The Toronto Purchase ..................................................................................... 103

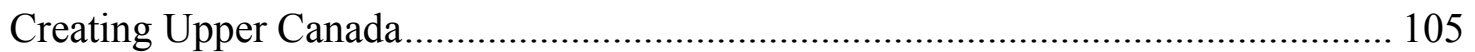

Negotiating the Mississauga Tract......................................................................... 109

Settler Colonial Depression of Land Prices ......................................................... 111

Wychwood Park's History of Subdivision ............................................................ 115

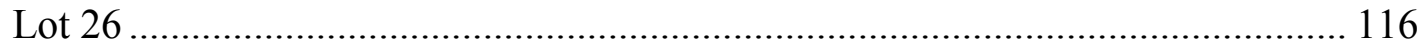

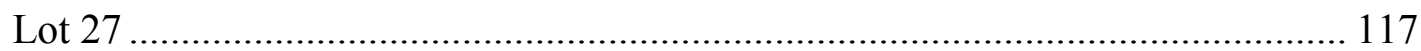

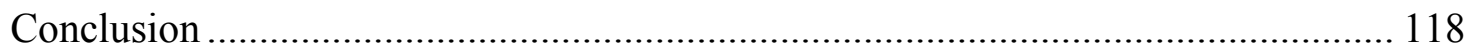

Chapter Four Settler Indigenization: The Aestheticization of Appropriated Territories in Art, Architecture, and Landscape Design ........................................... 120

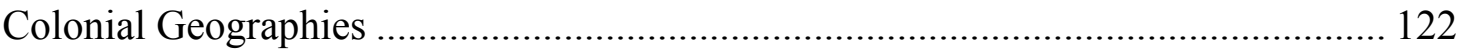

Wychwood Park and Settler Colonial Place-Making ........................................... 127

Wychwood Park History: Arrival of the Artists ................................................... 129

Garden Suburbs and the Arts and Crafts Movement ............................................. 133

George Reid's Upland Cottage ............................................................................ 135

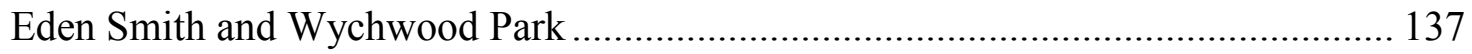

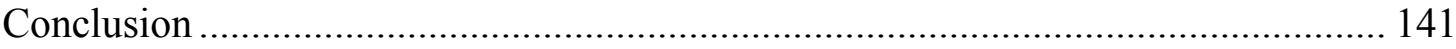

Chapter Five Indigenization II: Wychwood Park's Public Heritage ....................... 143

Settler Colonialism's Relationship to Inheritance ................................................ 145

Constructing Heritage in Ontario: The Cult of the Pioneer ..................................... 149

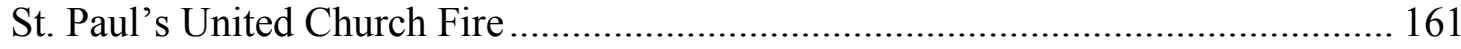

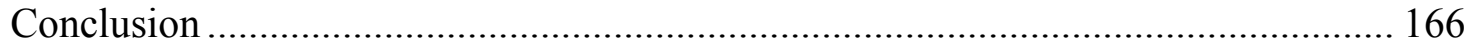

Chapter Six Colonial Transcendence and the Whiteness of Wychwood Park ....... 168

Social Reform and Imperialism in Early-Twentieth-Century Toronto...................... 175

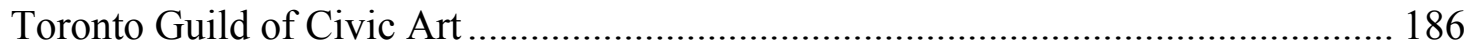




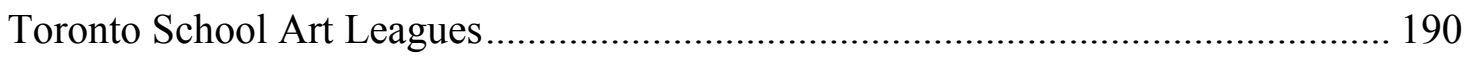

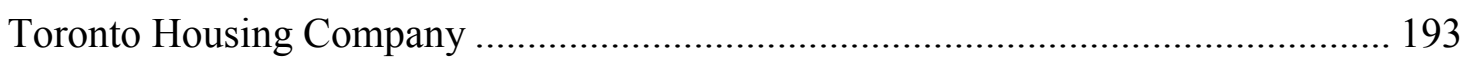

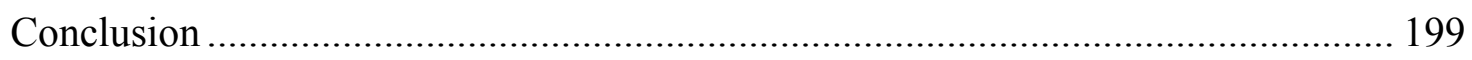

Conclusion .................................................................................................................................. 202

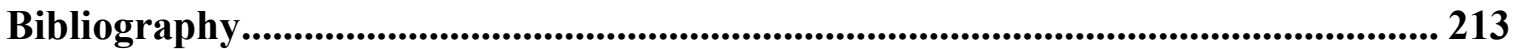




\section{List of Figures}

Figure 1.1 Map of Wychwood Park. Neighbourhood Guide: Toronto and the GTA. https://www.neighbourhoodguide.com/toronto/midtown/wychwood-park ..................... 2

Figure 1.2 3 Wychwood Park. Toronto Public Library.................................................. 3

Figure 1.36 Wychwood Park. Toronto Public Library...................................................... 3

Figure 1.419 Wychwood Park. Toronto Public Library.................................................. 4

Figure 1.5 Wychwood Park's communally owned tennis court. Maple Tree Publishing,

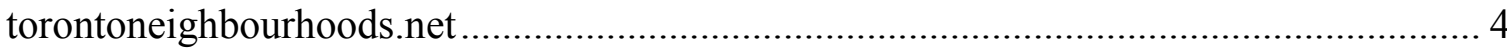

Figure 1.6 Portrait of Marmaduke Matthews by George A. Reid, 1898. Toronto Public Library.

Figure 1.7. Marmaduke Matthews' house, Wychwood, built in 1873. Toronto Public Library.

Figure 1.8 View from Alexander Jardine's house, with Seaton Village in the background, in 1878. Toronto Public Library. 15

Figure 1.9 George Agnew Reid at home, 1907. Archives of Ontario............................ 17

Figure 1.10 Eden Smith, George Howell, and Gustav Hahn. City of Toronto Archives. . 18 Figure 3.1 Plan 332. From: Keith Miller, History and Development of Wychwood Park.

Figure 4.1 Survey of the Township of York by Alexander Aiken around 1793. The Davenport Trail is highlighted across the top of the image. http://heritagetoronto.org/thedavenport-trail/

Figure 4.2 Map of the Taddle Creek Course. http://lostrivers.ca/content/taddlekey.html 125

Figure 4.3 Cutting ice on Wychwood Pond, 1910. Toronto City Archives. 126

Figure 4.4 Moving a house in Wychwood Park 1910. Toronto Municipal Archives. .... 131 Figure 4.5 Upland Cottage. http://occasionaltoronto.blogspot.ca/2010/07/.................. 135

Figure 4.6 Mary Hiester Reid inside Upland Cottage, 1911. Toronto City Archives..... 137

Figure 4.7 Eden Smith's former home at 5 Wychwood Park. Photo by Bob Krawczyk, used courtesy of the Architectural Conservancy Ontario.

https://torontoist.com/2017/07/historicist-eden-smith-arrival-arts-crafts-movementtoronto/

Figure 4.8 7 Wychwood Park, designed by Eden Smith for George Howell in 1910. Neighbourhood Guide: Toronto and the GTA. https://www.neighbourhoodguide.com/toronto/midtown/wychwood-park 140 


\section{Prologue Notes from My Research Journal}

June 24, 2013. Toronto Land Records Office, 20 Dundas Street West. $11 \mathrm{am.}$

Me: Thanks for your help in locating the land transfer document from this address in Wychwood Park, but my question goes back before 1888. I want to know who owned the land before it was subdivided.

Toronto Land Records Office Staff: Before it was subdivided? I don't understand what you mean. No one owned it.

Me: What I mean is, surely there was some kind of agreement that took place in order to have this subdivision registered. How would someone apply to subdivide this tract of land back in 1888 ?

Toronto Land Records Office Staff: They registered this plan. That's why the first date is 1888 , see? They were the first owners of this land.

Me: But who did they register the land with? I mean, was this Crown land?

Toronto Land Records Office Staff: Oh, I see. Yes. Yes. Crown land.

Me: And how did it become Crown land?

Toronto Land Records Office Staff: What?

Me: Well, was this area part of the Toronto Purchase? I mean, what was the legal status of this territory prior to it being registered as Plan 854 ?

Toronto Land Records Office Staff: You're going back way further than the documents we deal with. I have no idea what you're asking.

Me: I'm trying to figure out how long this land has been recognized as Crown Land. I want to know what the land was called before it was called Crown Land.

Toronto Land Records Office Staff: ... But that's what I'm trying to say: there was no before. All of our records start when all the land was Crown Land.

Me: Well but how would I -

Toronto Land Records Office Staff: You're not listening. This has always been Crown Land. There is no answer to your question. It's irrelevant. If I were you, I wouldn't bother asking it. 


\section{Chapter One \\ Wychwood Park as a White Settler Colonial Landscape}

Wychwood Park is a gated community in midtown Toronto that encompasses

fifty-eight homes built around a private roadway. It was originally established in 1888 , though the first major wave of residential settlement took place from 1905-1918.

Residents own their individual homes, and collectively own shared green space and the roadway within the Park's gates through a land trust. Wychwood Park sits within a forested escarpment north of Davenport Road, just west of Bathurst Street.

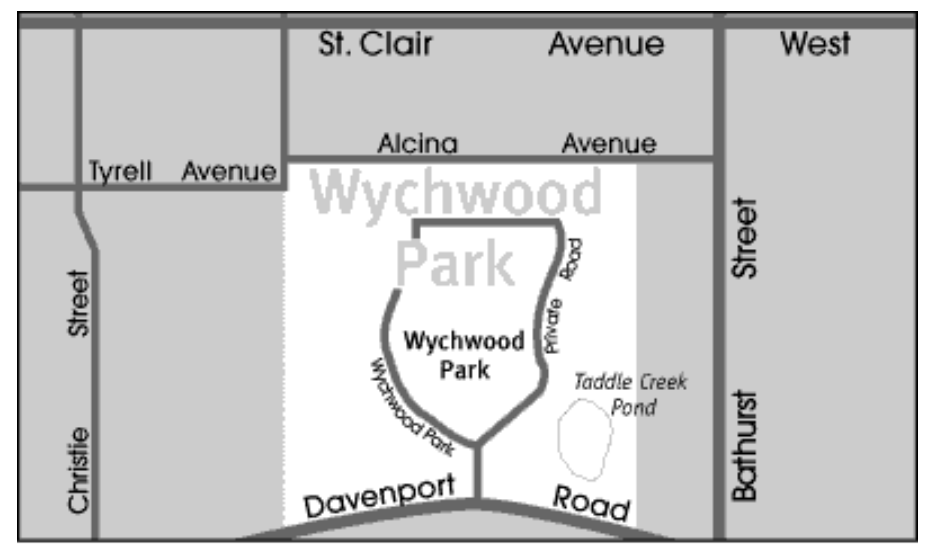

Figure 1.1 Map of Wychwood Park. Neighbourhood Guide: Toronto and the GTA. https://www.neighbourhoodguide.com/toronto/midtown/wychwood-park

Wychwood's trees are so lush and dense that cars driving along either of the adjacent thoroughfares can barely make out the Park's sprawling, Arts and Crafts-style homes from the street. Within the Park's gates, Toronto's bustling tempo is inaudible. The privacy of the Park, combined with its celebrated domestic and landscape architecture, make it one of Toronto's most unique neighbourhoods. Figures 1.2-1.4 demonstrate the beauty of Wychwood Park's architecture and park-like setting. 


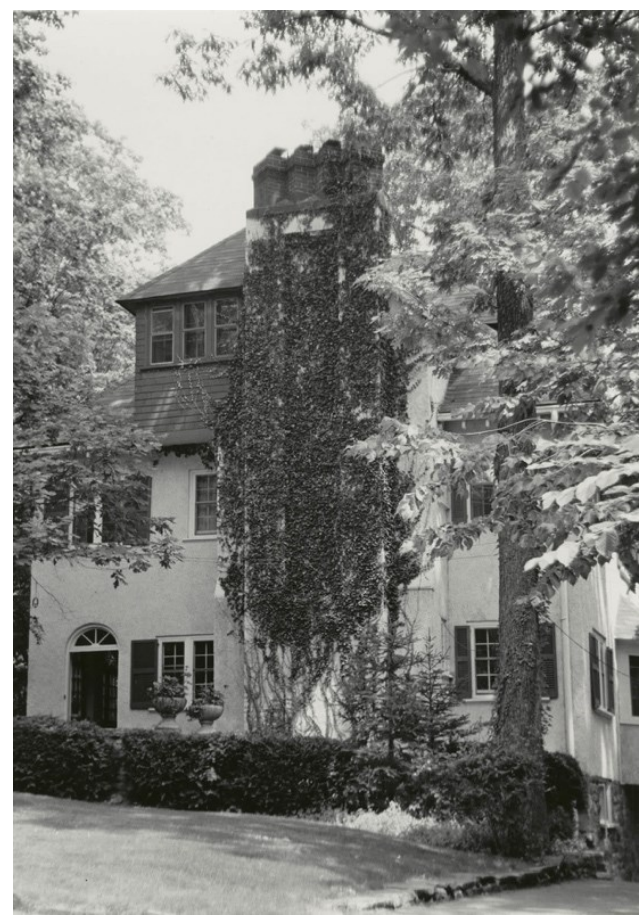

Figure 1.2 3 Wychwood Park. Toronto Public Library.

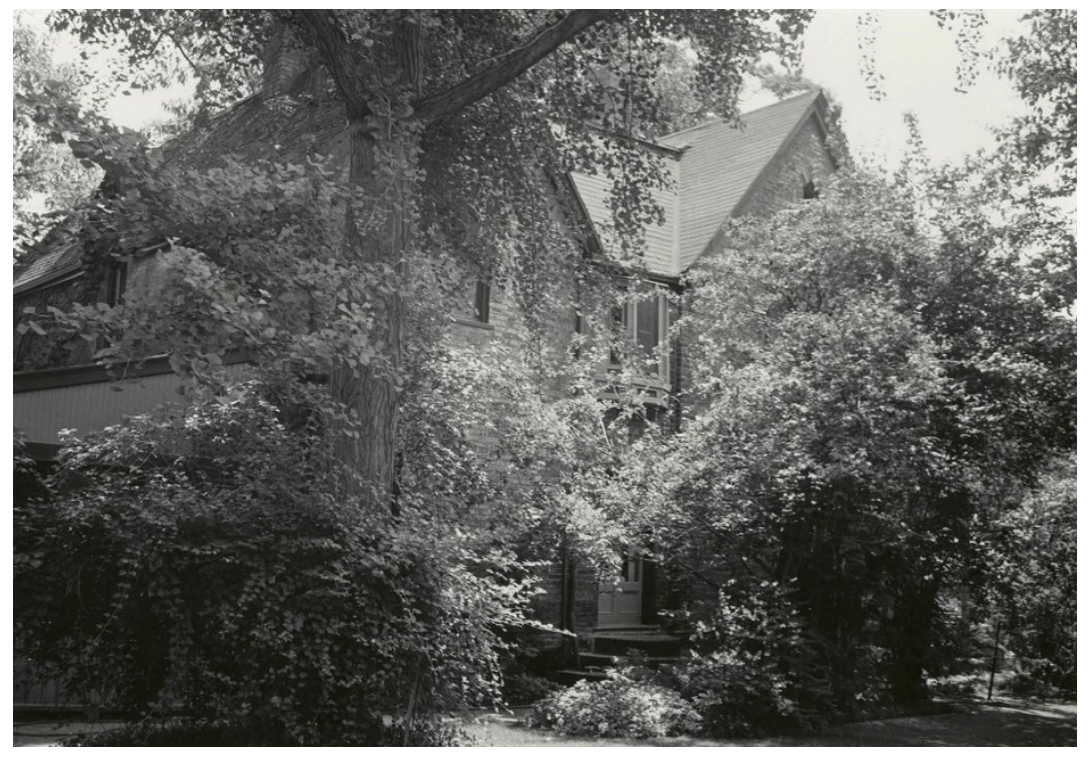

Figure 1.3 6 Wychwood Park. Toronto Public Library. 


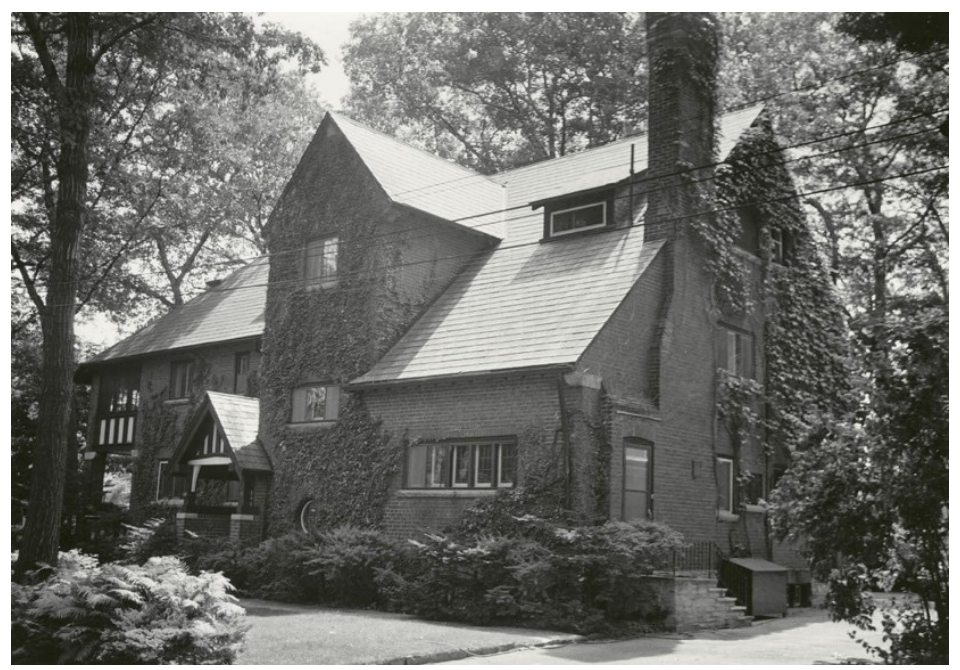

Figure 1.4 19 Wychwood Park. Toronto Public Library.

Pedestrians can enter the gates through Wychwood Avenue, at the Park's north end, and follow a circular driveway that winds through the ten-acre neighbourhood, passing houses that are arranged at different angles to the street in order to maximize their exposure to sunlight. A large pond in the east end of the Park is home to turtles and swans, next to an outdoor tennis court speckled with shade from thick foliage hanging overtop. Wychwood Park is, inarguably, a beautiful place.

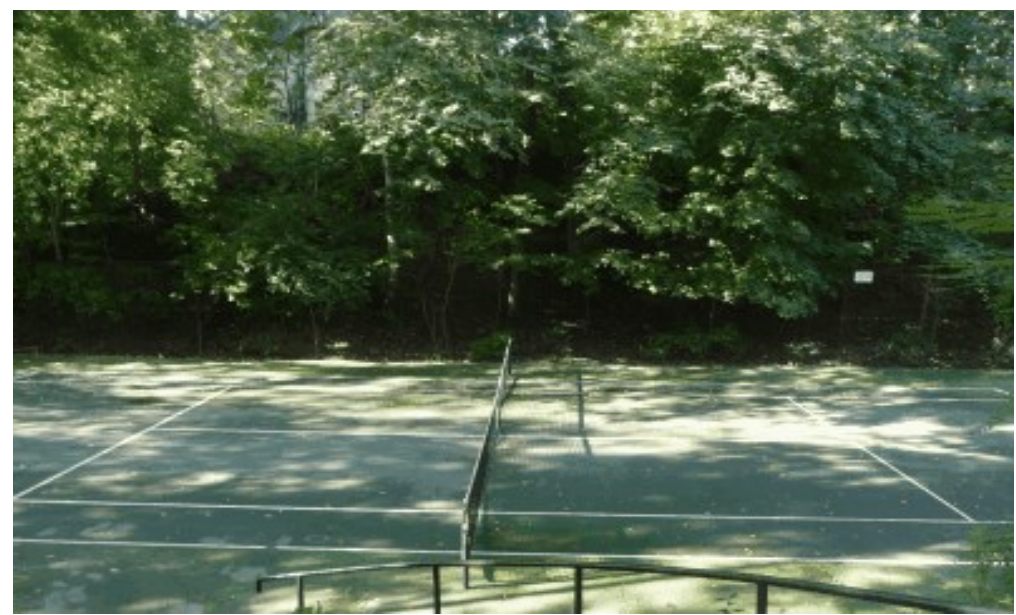

Figure 1.5 Wychwood Park's communally owned tennis court. Maple Tree Publishing, torontoneighbourhoods.net 
Wychwood Park is a coveted, expensive neighbourhood, and it has not been uncommon for celebrities to call the Park home. Media theorist Marshall McLuhan was a Park resident in the 1970s, as was media mogul Moses Znaimer in the 1980s.

Neighbourhood gossip is often profiled in The Globe and Mail and Toronto Life

Magazine. ${ }^{1}$ Not only is the Park an exclusive postal code for Toronto's elite, it is also a provincially designated "heritage district," so named because of the significance of its landscape design and architecture.

Wychwood Park's landscape plan is one of Canada's earliest examples of a garden suburb - a suburban design model derived from the turn-of-the-twentieth-century English Garden City movement. Further, the Park boasts the highest concentration of Arts and Crafts domestic architecture in Toronto, designed by local architect Eden Smith at the turn of the twentieth century.

\section{Argument Overview}

This dissertation argues that Wychwood Park is a white settler colonial landscape. By using the language of "white settler colonial," I emphasize Wychwood Park's significance as a landscape that is embedded in the settler colonial dynamics that produce racialized space. My work is strongly informed by the field of Critical Whiteness Studies, which serves to de-naturalize whiteness as an unspoken norm within scholarship and social life. In the last two decades, settler colonial studies has become organized as a subfield of critical scholarship, producing ways of understanding the specific cultural,

\footnotetext{
${ }^{1}$ See, for example, Jim Rankin, "Inside the Weird World of Wychwood Park," Toronto Star, December 21, 2012; Simone Olivero, "House of the Week: \$5.5 Million for a Wychwood Park Home with a Backyard Tennis Court," Toronto Life, June 26, 2013; Simon Avery, "The Wychwood Park Mystery," Globe and Mail, May 16, 2003.
} 
economic, political, and spatial dimensions of settler colonial social organization. Studies of Canadian settler colonialism emphasize territoriality - ways that Canadian settler society has appropriated land, invented a sense of home on the land, commodified land, developed settler land-based epistemologies, and denied Indigenous land title. These themes reveal settler colonialism as a spatializing practice, demonstrating how colonial occupation transforms territories and cartographies. Contemporary contributions in the field have studied settler colonial cities as spaces of "organized forgetting,", an orientation to settler colonial dynamics reflected by the land records staff in my prologue. The relationship between urban processes and settler colonial power is currently an area of dynamic examination within the field. ${ }^{3}$ While this dissertation shares common themes with this literature, it is beyond the scope of my study to intervene in the debates among urban specialists within settler colonial studies.

I have organized my research to answer the following questions: If the field of settler colonial studies invites scholars to understand every social and territorial dynamic

\footnotetext{
${ }^{2}$ Nicholas Blomley, "Law, Property and the Geography of Violence: The Frontier, The Survey, and the Grid," Annals of the Association of American Geographers 93, no. 1 (2003): 128.

${ }^{3}$ Recent studies of settler colonial cities include N.J.K. Baloy, "Spectacles and Spectres: Settler Colonial Spaces in Vancouver," Settler Colonial Studies 6, no. 3 (2016): 209-34; Nicholas Blomley, Unsettling the City: Urban Land and the Politics of Property (New York: Routledge, 2004); Glen Coulthard, Red Skin, White Masks: Rejecting the Colonial Politics of Recognition (Minneapolis: University of Minnesota Press, 2014); Penelope Edmonds, "Unpacking Settler Colonialism's Urban Strategies: Indigenous Peoples in Victoria, British Columbia and the Transition to a Settler Colonial City," Urban History Review/Revue d'histoire urbaine 38, no. 2 (2010): 4-20; David Hugill, "What Is a Settler Colonial City," Geography Compass 11, no. 5 (2017): 1-11; David Hugill, "Settler Colonial Urbanism: Notes from Minneapolis and the Life of Thomas Barlow Walker," Settler Colonial Studies 6, no. 3 (2016): 265-78; David Hugill, "Metropolitan Transformation and the Colonial Relation: The Making of an 'Indian Neighbourhood' in Postwar Minneapolis," Middle West Review 2, no. 2 (2016): 169-200; David Hugill and Owen Toews, "Born Again Urbanism: New Missionary Incursions, Aboriginal Resistance and Barriers to Rebuilding Relationships in Winnipeg's North End," Human Geography 7, no. 1 (2014): 69-83; Heather Dorries, "Planning as Property: Uncovering the Hidden Racial Logic of a Municipal Nuisance By-Law," Journal of Law and Social Policy 27 (2017): 72-93; Julie Tomiak, "Contesting the Settler City: Indigenous SelfDetermination, New Urban Reserves and the Neoliberalization of Colonialism," Antipode 49, no. 4 (2017): 928-45; Libby Porter and Oren Yiftachel, eds., "Settler Colonialism, Indigeneity, and the City," special issue, Settler Colonial Studies 9, no. 2 (2019); Owen Toews, Stolen City: Racial Capitalism and the Making of Winnipeg (Winnipeg: ARP Books, 2018).
} 
in Canada as related to settler colonialism, how is Wychwood Park situated within these dynamics? In what ways is Wychwood Park's relationship to settler colonialism publicly acknowledged, and in what ways is this relationship publicly disavowed? This dissertation invites a reconsideration of Wychwood Park's role in the cultural life of Toronto, situating it within the gendered and racialized discourses of settler colonial place-making. By extension, this dissertation also rebuts the patterns in existing research related to Wychwood Park that have consistently failed to identify ways that the Park and its reputation are embedded within systemic settler colonial ways of understanding.

\section{Research Context}

Wychwood Park is one of Toronto's most profiled neighbourhoods, regularly featured in the pages of Toronto Life magazine and the National Post, Toronto Star, and Globe and Mail newspapers. The Park has been referred to as an "oasis,", a "leafy eden,", a "village suspended in the ebbtide of the $18^{\text {th }}$ century, medieval in its season and silences." These descriptors highlight Wychwood Park's natural beauty, whose "lushness and lack of modern planning make it easy for visitors to miss."7 Such characterizations of the Wychwood Park landscape construct it as an idyllic environment. When describing the Park's architecture, a Toronto Star columnist noted that "fake half-timbering and leaded lights underline the old country nostalgia in this bit of Oxfordshire in the colonial wilds." ${ }^{8}$ According to the sources I have briefly cited, Wychwood Park is beautiful

\footnotetext{
4 "Wychwood Park: An Oasis of Green Among the Asphalt," Canada Home Décor, Summer 1979, 56.

${ }^{5}$ William Morris Society of Canada Newsletter, Winter 1991-2, 5.

${ }^{6}$ James Purdie, "Toronto's Unique Private Enclave for 53 Families," Toronto Life, April 1970, 50.

${ }^{7}$ Andre Ramshaw, "Best of TO: Forever an England in a Tiny Corner of the West End," National Post. Wychwood Park fonds, City of Toronto Archives.

${ }^{8}$ Leon Whiteson, "Wychwood Park: A Tranquil Retreat for a Metro Elite," Toronto Star, January 16, 1982.
} 
because it is an English kind of beautiful, and the extent to which we are successfully tricked into imagining we have just travelled back in time upon entering the Park's gates signals how linked the idea of Toronto history is to signifiers of cultural Englishness. The descriptions I have cited constitute a discourse in the Foucauldian sense of the word, by which I mean that they highlight power relations through language. Describing the Park as invocative of "old country nostalgia" promotes the idea of Toronto's history as English history. In this way, the celebration of Wychwood Park's capacity to invoke nostalgia for medieval England naturalizes the sustained British colonial occupation of Toronto.

Early residents of Wychwood Park were artists, art workers, and art patrons who shared similar design goals and curated the landscape environment to embody an English garden aesthetic. They moved into the Park in the early twentieth century and designed their own homes and gardens. Many early Wychwood residents were also colleagues, collaborating on a variety of initiatives to democratize the visual arts in Toronto, establish art galleries and training schools, and beautify the cityscape. Park residents embraced and promoted the linking of social and aesthetic values - an ethos reflected by late nineteenth century cultural thinkers like Patrick Geddes, Matthew Arnold, and Candace Wheeler. The Arts and Crafts architecture of many Wychwood Park homes speaks directly to the influence of Arts and Crafts Movement leaders like William Morris and John Ruskin. For Wychwood Park residents and their contemporaries, social improvement and aesthetic improvement went hand in hand. They believed the strength of a society could be judged in part on the strength of its art and urban design. Therefore, it is important that the significance of Wychwood Park and its early residents be assessed in relation to the role 
the Park played in the broader social and cultural life of Toronto at the turn of the twentieth century.

Wychwood Park was established at the height of Toronto's turn-of-the-century public sanitation crisis, when overcrowded inner-city slum housing fostered high rates of infectious disease, factory smoke covered Toronto's downtown core, and industrialized waste polluted the waterfront. In the context of these environmental, health, and housing crises, Wychwood Park emerged as a bucolic antidote to the congested chaos of downtown. Not only was the Park clean, it was beautiful - the kind of beauty that could invoke nostalgia for an imagined English past.

In the early twentieth century, Wychwood Park's forested suburban beauty contrasted with the polluted inner city spatially, but this distinction was materialized in racial terms as well. At the turn of the twentieth century, Toronto was in the middle of an intense period of immigration, with the city's population quadrupling between 1880 and 1910. Many downtown residents living in poverty were non-Anglo immigrants, and racist anxieties circulated that equated inner-city filth with the perceived moral ineptitude of racialized communities. Wychwood Park, with its aestheticized English gardens and edenic cleanliness served as a civilized, white corollary to the racialized poverty of the polluted inner city.

The role Wychwood Park played - socially, politically, and symbolically - at the turn of the twentieth century continues to be reproduced within the contemporary cultural and intellectual imagination of Toronto. The Park's history during the period of 19051918 was cited as the justification for designating the neighbourhood officially "historical" in 1983. Early twentieth-century residents of the Park continue to be lauded 
in local and institutional histories as central figures responsible for establishing a national arts tradition in Canada. The literature on Canadian art history consistently credits former Wychwood residents as national leaders. Praising art and cultural workers for their contributions to the development of a national arts apparatus simultaneously associates national progress with artistic output, and positions the Park as nationally significant. Just as the discursive construction of Wychwood Park as historically British frames its natural environment as an original site for the burgeoning Canadian nation, the cultural and artistic labour of Wychwood Park residents is similarly symbolic of the nation's progress.

This dissertation explores the racial, spatial, and cultural dimensions of settler colonial society at the turn of the twentieth century in Toronto through the case study of Wychwood Park. My focus on Wychwood Park as a site for settler colonial meaningmaking highlights the role of artists and cultural workers in turn-of-the-century efforts to build the Canadian nation. This dissertation invites closer examination of artistic and cultural labour as possessing agency within settler colonial processes. Importantly, none of the existing research on Wychwood Park and its early residents addresses its position within settler colonial social formations. As I demonstrate throughout this dissertation, the study of Wychwood Park requires a lens of analysis that integrates the study of landscape design, civic nationalism, public art, domestic architecture, and urban planning. To date, the majority of research on the Park and its early residents has been conducted by local, art, and architectural historians, whose studies have isolated the Wychwood Park story into disciplinary siloes. Studies of the Park's history are divorced from studies of the art produced by its residents, and their civic lobbying efforts are described without reference to how their social values were reflected in the very houses they designed for their 
families. This dissertation both elaborates on existing research on the Park and argues for cultural studies of early twentieth-century Toronto to address the analytic tools formalized by settler colonial studies. My dissertation responds to debates within cultural sectors such as museums and art galleries that address colonialism only when discussing the representations of Indigenous communities. This research invites further consideration into how settler art and cultural production could benefit from a disciplined anti-colonial analysis.

By way of example, in 2013, a major exhibition opened at the National Gallery of Canada titled Artists, Architects, and Artisans (AAA). It was an unprecedented and comprehensive study of the ways that artists, architects, and artisans worked together on various building projects in Canada from 1890-1918. The $A A A$ exhibition and its catalogue offered a major contribution to the study of Wychwood Park because urban planning, landscape design, public art, and architecture were integrated within its broad scope. Nearly every organization and artistic or architectural movement to which Wychwood Park residents contributed were profiled in the $A A A$ exhibition. However, the major limitation of the exhibition remained the fact that while artists and architects were studied within a broader context that included urban planning and landscape design, the exhibition was silent on the subject of settler colonialism. Overall, the exhibition argued for a more integrated analysis of artistic labour, but one bereft of how that labour related to the intensification of land appropriation and violence against Indigenous peoples. The failure of $A A A$ to situate settler colonialism within a scope of cultural analysis that was unprecedented in its breadth speaks to a larger intellectual convention of disavowal when it comes to the salience of settler colonialism in Canada. 
$A A A$ opened in November 2013. The exhibition that immediately preceded it at the National Gallery was Sakahan: International Indigenous Art, a major exhibition of contemporary Indigenous art from around the world. Four years later, in 2017, the National Gallery's Canadian galleries were renovated and remounted as the "Canadian and Indigenous Galleries," an effort to integrate settler and Indigenous art in the same scope, time frame, and physical exhibition space. As I write this, the main exhibition is Abadakone: Continuous Fire, a second major international exhibition of contemporary Indigenous art. These exhibitions demonstrate a commitment to changing conventional colonial exhibitionary practices that have been applied to Indigenous art. However, the National Gallery of Canada remains ambivalent about the extent to which conventional colonial practices can also be changed when settler art and artistic contributions are at stake. This ambivalence is reflected in every sector of Canadian society, and every academic discipline. Calls for reconciliation are often mistakenly applied only to contexts associated with Indigeneity, but rarely are there models of reconciling settler culture with its own investment in settler colonial knowledge systems.

My study of Wychwood Park builds upon the integrative work of $A A A$, arguing that significant contributions made to the arts, urban planning, architecture, and landscape design in the early twentieth century were constitutive of the settler colonial society in which they took shape. To do this, I focus on the role of the land in the cultural and geographic imaginations of early Wychwood Park residents: how they claimed ownership of the land, how they aestheticized its landscape, how their art ensured a sense of settler colonial belonging on the land, and how they distinguished their neighbourhood from other neighbourhoods in the city. 
In this dissertation, I argue that Wychwood Park is a white settler colonial landscape. This argument is informed by the idea of landscape as an actor in social and political processes, rather than a reflection of them. The physical landscape of Wychwood Park, and the extent to which it reflects the ideas and values that sustain settler colonial rule, are seriously interrogated in this project. I am interested in the ways that a neighbourhood like Wychwood Park can teach Torontonians something about how racism works and what it means to live in an environment shaped by racialized thinking and social organization. I am informed by Richard Schein's contentions that “discourses of racialized social relations work through landscapes"9 and that landscapes are the sites in which racialized discourses become "materialized." ${ }^{10}$ In this dissertation, I situate the racialized social relations of settler colonialism within the material landscape of Wychwood Park. This approach highlights Wychwood Park's engagement with the settler colonial project, addressing a gap in existing literature on the Park specifically and on Toronto history as a whole. In what follows, I offer a history of the Park and how it has been studied.

\section{History of Wychwood Park (1888-1920)}

Wychwood Park was established in 1888, when two neighbours living in country lots north of Toronto combined their land and registered a subdivision with the Township of York, naming it Wychwood Park. In the latter half of the nineteenth century, the City of Toronto was expanding rapidly, annexing small villages and towns every few years.

\footnotetext{
9 Richard Schein, “A Methodological Framework for Interpreting Ordinary Landscapes: Lexington, Kentucky's Courthouse Square,” Geographical Review 99, no. 3 (2009): 396.

${ }^{10}$ Richard Schein, "The Place of Landscape: A Conceptual Framework for Interpreting an American Scene," Annals of the Association of American Geographers 87, no. 4 (1997): 666.
} 
Anticipating that their land in the growing township would soon be annexed to the City of Toronto, watercolour painter Marmaduke Matthews (1837-1913) and business owner Alexander Jardine created Wychwood Park, redrawing the boundaries of the 1888 subdivision three years later in 1891 to make room for even more lots of record than initially planned. The plan of subdivision designated thirty-eight residential plots intended for future sale. Matthews and his family had been living in their home since 1873, when he originally bought his plot, and Alexander Jardine had been his neighbour since $1874 .{ }^{11}$ The 1891 subdivision also lists a series of investors (family members) who collectively were named as owners of the title, as well as trustees for the common lands noted within the plan of subdivision.

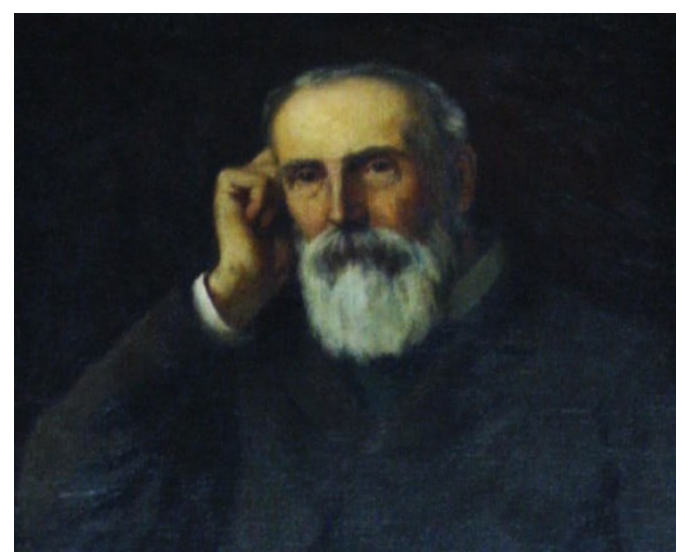

Figure 1.6 Portrait of Marmaduke Matthews by George A. Reid, 1898. Toronto Public Library.

The name for Wychwood Park comes from “Wychwood,” Marmaduke Matthews' house. Matthews named his home after the Wychwood Forest in Oxfordshire, where he was raised prior to immigrating to Canada in 1860 at the age of twenty-three.

${ }^{11}$ Alexander Jardine is listed as a landowner of the site from 1874. It is possible a house was not built until 1877, as that is the date of construction listed for Braemore in the Wychwood Park Heritage Designation Plan. 


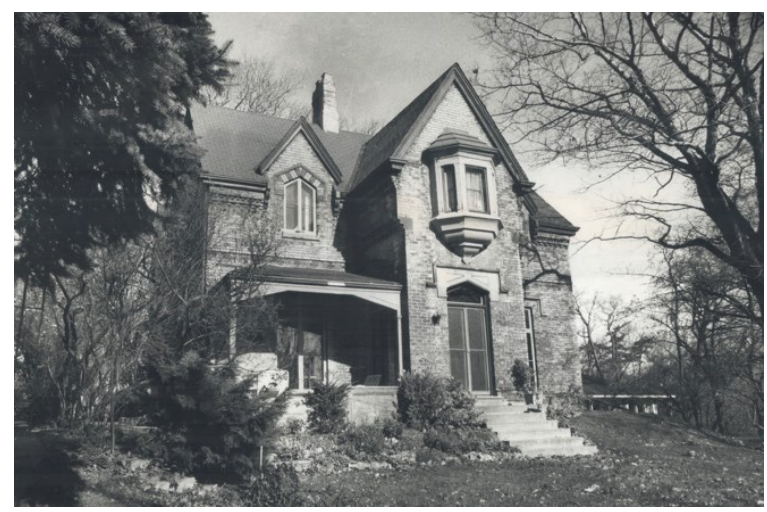

Figure 1.7. Marmaduke Matthews' house, Wychwood, built in 1873. Toronto Public Library.

Alexander Jardine lived in a house named "Braemore" (now also the name of a neighbouring street). Between 1873 and 1905, the two families lived in their country houses approximately twenty yards apart without any other close neighbours.

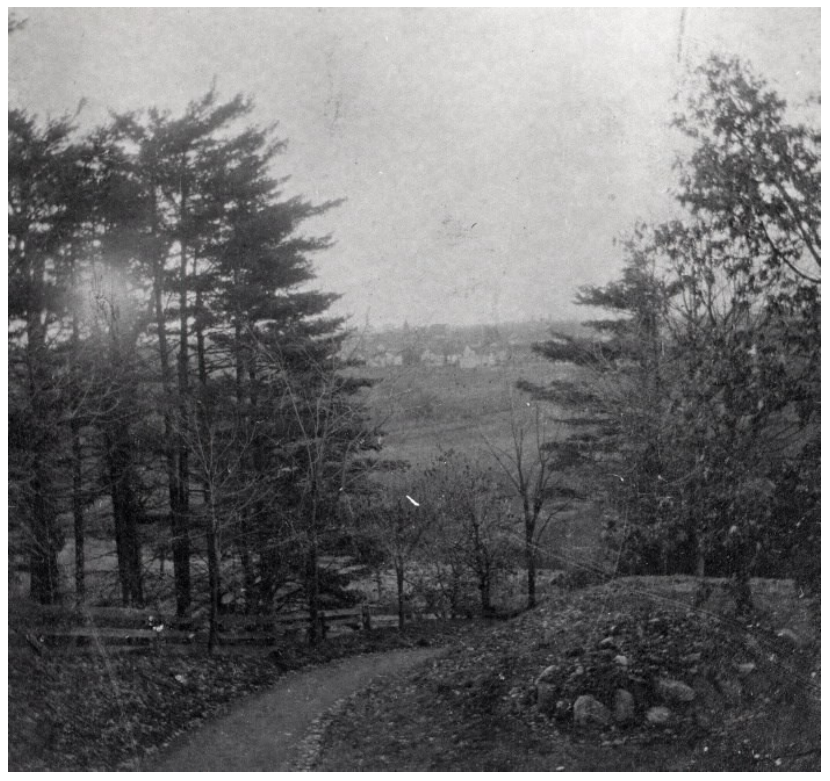

Figure 1.8 View from Alexander Jardine's house, with Seaton Village in the background, in 1878. Toronto Public Library. 
In 1905, the first lot in Wychwood Park was sold to painters George Agnew Reid (1860-1947) and Mary Hiester Reid (1854-1921), a married couple working to build a visual arts tradition in Canada.

George Reid designed his own house in the Park, which embodied many stylistic features embraced by the Arts and Crafts Movement. The Reid house, named Upland Cottage, was built with separate studio space for both George and Mary, including rooms to exhibit art and host events. Matthews would have known the Reids through the arts community. In 1905, the Reids were leaders in the visual arts in Toronto, having met as art students studying under Thomas Eakins in Philadelphia in 1885, later travelling together to Europe to study art and playing major roles in developing an arts apparatus for Toronto and English Canada. In 1905, George Reid was the past president of the Ontario Society of Artists, and would shortly become the president of the Royal Canadian Academy of Arts. His pioneer murals depicting the early European settlement of Toronto were unveiled in Toronto's City Hall in 1899, and in 1905 he was in the process of negotiating a permanent site and funding structure for what would eventually become the Art Gallery of Ontario (AGO). 


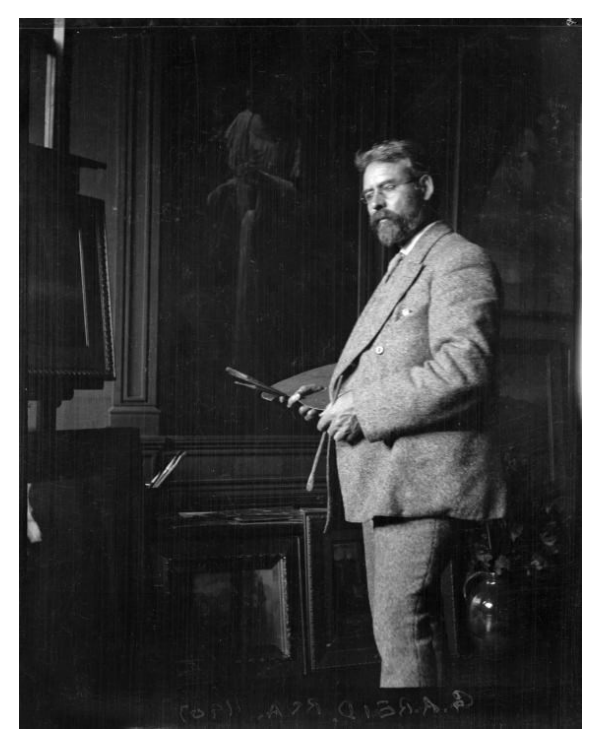

Figure 1.9 George Agnew Reid at home, 1907. Archives of Ontario.

When the Reids decided to move to Wychwood Park, they enticed their friends and neighbours to follow suit. The Reids had been living on Indian Road in what is now the High Park neighbourhood in the late 1890 s, in close proximity to artist friends, many of whom would follow them to Wychwood Park. By 1919, the Park included residents such as artist Mary Wrinch (1877-1969), architect Eden Smith (1858-1962) with his apprenticing sons Harry (1882-1959) and Ralph (1890-1972), muralist and designer Gustav Hahn (1866-1962), founding Royal Ontario Museum (ROM) curator Charles Currelly (1876-1957), and University of Toronto biology professor Edmund Merton Walker (1877-1969), son of civic leader and art patron Sir Byron Edmund (B.E.) Walker (1848-1924). George Reid, like Hahn and Smith a follower of the English Arts and Crafts Movement, took a leadership role in developing the Park's aesthetic, including formalizing a set of proto-bylaws that ensured domestic and landscape architectural unity. Eden Smith, who would go on to be known as Toronto's most famous Arts and Crafts architect, designed the majority of the houses in the Park during this time. As a whole, 
Wychwood Park residents shared similar goals and interests in art and design. It was through social relationships that new residents found out about the Park and would purchase new lots. There is no evidence of any public advertising having been used to market the Park to potential new buyers.

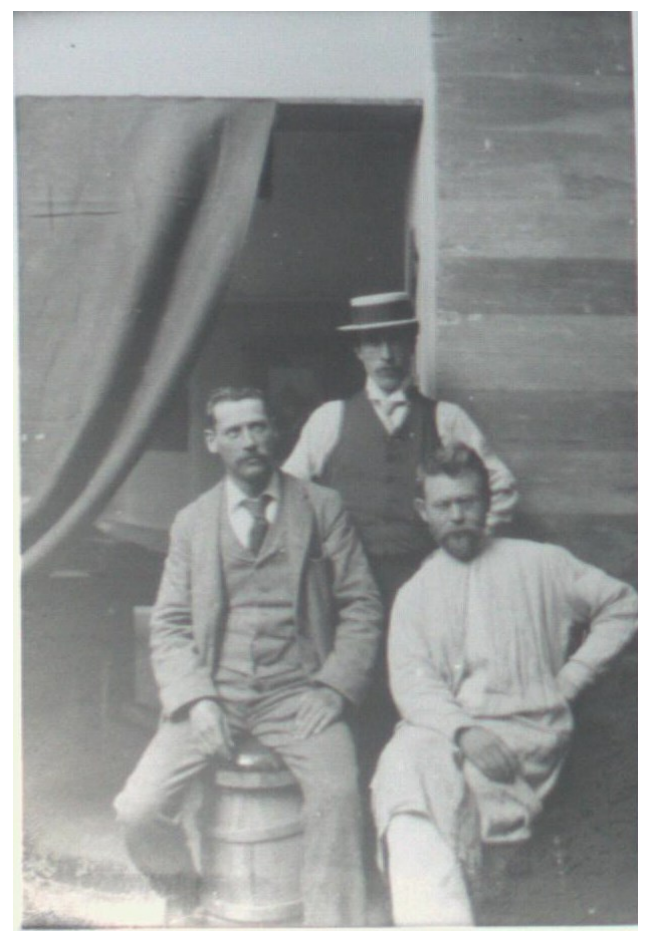

Figure 1.10 Eden Smith, George Howell, and Gustav Hahn. City of Toronto Archives.

Throughout this dissertation, when I refer to "former residents" or "famous residents," or even simply "Wychwood residents," I am referring to those who moved into the Park during this period, and most often to George Reid, Eden Smith, and Gustav Hahn. Houses from this period of development (1905-1918) share an architectural cohesiveness, oversized and irregularly shaped lots, and large frontages.

In 1918, the land trust was reorganized and significant portions of undeveloped land were sold to a builder, A.E. Whatmough, who subdivided his land into smaller lots and built twenty-seven more houses. The architectural style of Whatmough's designs are 
compatible with the first wave of house building, but appear more uniform with, and are built on significantly smaller lots. ${ }^{12}$ Between 1950 and 1982, five new lots were created out of existing lots, and the houses built during this time reflect modernist trends in domestic architecture. The houses built between 1905 and 1918 are those commonly associated with Wychwood Park's notoriety, though there are many homes in the Park that do not conform to the aesthetic or style of Eden Smith's original architectural designs.

\section{Heritage District Legislation (1970-1983)}

For the majority of the twentieth century, Wychwood Park existed as a uniquely landscaped but otherwise indistinct residential community in midtown Toronto. Marshall McLuhan once commented to a reporter that "The point of the park ... is that it has no function, no goal, no objective. It's an Agatha Christie place, unexpected, inexplicable, and it's a community in every sense." ${ }^{13}$ While the Park was widely known for its low density and forested landscape, the community did not organize itself around a particular origin story or collective identity. In the 1970s, residents were seeking ways of preventing further development that could potentially "[destroy] the beauty and distinctive character of the Park." ${ }^{14}$ Anxieties were raised by the potential that existing lots of record could be developed to their maximum potential. Community leaders were interested in having the Park protected under heritage legislation - a designation that would limit future residential development within the Park's gates. In 1980, the Ontario Heritage Act was amended to extend historic designations beyond singular properties to encompass whole

\footnotetext{
${ }^{12}$ Wychwood Park Heritage Conservation District Plan (Toronto; Toronto Historical Board, 1986), 18.

${ }^{13}$ Purdie, "Toronto's Unique Private Enclave," 50.

${ }^{14}$ Wychwood Park Heritage Conservation District Plan, 4.
} 
neighbourhoods or districts. The provincial government requested applications for potential historic sites to be used as case studies to test the policy language in the proposed amendments. As part of a pilot program, community organizations could go through the process of becoming historically designated, while also offering feedback to the provincial government on how the language in the heritage legislation could be improved to reflect the needs of heritage districts. Residents of Wychwood Park volunteered to partner with the Toronto Historical Board to conduct a feasibility study for the historic designation.

A team of consultants was hired to study Wychwood Park for its heritage proposal. Over a process that spanned ten years, the Park was eventually historically designated in 1983 - the first historic district to be named in the province of Ontario. The reasons for Wychwood Park's historic significance was not justified on the basis that the houses themselves were old (there were no houses over a century old, after all). Rather, Wychwood Park qualified for heritage protection based on the "distinctive character" of the Park, achieved by having houses "blend into the landscape." 15 As the Toronto Historical Board pointed out, "Wychwood Park is laid out in such a manner that the grounds appear as a series of three-dimensional landscape paintings. Buildings are nestled into the landscape. An organized spatial quality is quite evident, with divisions into the foreground, middle ground, and background. In the older section, houses are rarely in full view; rather, they are glimpsed through the trees with vegetation framing each image." Wychwood Park's heritage designation protects not just the Park, but how the Park commands the visitor's eye. What became protected by heritage legislation is a way of

\footnotetext{
${ }^{15}$ Wychwood Park Heritage Conservation District Plan, 17

${ }^{16}$ Wychwood Park Heritage Conservation District Plan, 20.
} 
looking at the land as one would a painting. Through the language of heritage protection, Wychwood Park was visually commodified in such a way as to reinforce the eye of the beholder.

As I demonstrate in this dissertation, Wychwood Park's aestheticized landscape reflects a settler colonial gaze. By "settler colonial gaze," I am referring to a way of seeing that legitimizes the settler colonial presence and consolidation of political and economic power in Toronto and Canada. By setting houses in, rather than on, the landscape, early Wychwood residents curated the visual aesthetics of the Park - visually transforming Indigenous territory into an English garden. The heritage designation celebrates the way the landscape was adjusted to frame English architecture and enhance its sense of belonging in the natural environment. By protecting this way of seeing, the heritage designation ensured that future generations would be encouraged to see and experience the landscape in similar terms.

The heritage designation formalized a public narrative of Wychwood Park's history that emphasized its cultural Englishness and distinguished the contributions of early residents as great men of Toronto history. To build a case for Wychwood Park to be deemed "historical," a usable past was constructed, re-storying the founding of the Park from a real estate investment into a vision for an artist's colony in suburban Toronto. Similarly, Marmaduke Matthews became re-cast from one of many initial investors into the original mastermind of Wychwood Park. Today, at the entrance to the Park, visitors are greeted by a plaque that reads:

Wychwood Park was named after Wychwood Forest in Oxfordshire, England, by Marmaduke Matthews, a landscape painter. He built the first house in the park in 1874 hoping to establish an artists' colony. In 1891 a subdivision plan was registered and a park reserve, including Taddle Creek and its pond, was vested in 
trust for the use of property owners. Many of the early houses are by Toronto architect Eden Smith and reflect the English Arts and Crafts Movement - simple composition and traditional English house forms, blended with the natural landscaped site. In its origins, development and operation, the park is a unique and early example of a planned community in Toronto. Wychwood Park was designated a Heritage Conservation district under the Ontario Heritage act in 1983. ${ }^{17}$

Within the historical narrative promoted by the plaque, Marmaduke Matthews is portrayed as a founding father, serving as the community's link to its Oxfordshire namesake. Prior to the heritage designation, Matthews was not publicly remembered as the original leader of Wychwood Park. However, once the community began organizing a public historical narrative of the Park, Matthews became constructed as a central figure.

The construction of Matthews as the founding ancestor within the Park's historical narrative is an example of how settler colonial discourse is infused with familial tropes. Canadian settler colonialism chronicles its own trajectory as a family genealogy. Just as the Canadian history books celebrate the efforts of the Fathers of Confederation, Wychwood Park's history locates its own significance within the prescience of a founding father. Like the Canadian national story, the story of Wychwood Park is told in such a way that present-day Wychwood Park residents are symbolically cast as the inheritors of Matthews's plan. In other words, the language of inheritance was used to place Wychwood Park within a broader national story. As I will demonstrate later in this dissertation, the notion of patrilineal inheritance informs a central logic of the settler colonial process in Canada. Land, as the primary commodity at stake within a settler colony, was part of an economic system designed to rely on patrilineal inheritance as a vehicle for creating inter-generational settler wealth. One of the discursive patterns I track

\footnotetext{
${ }^{17}$ Heritage Plaque, Toronto Historical Board, 1983.
} 
in this thesis is the ways in which Canadian settler colonialism is narrated as a family story. Highlighting Marmaduke Matthews as a founding father embeds the Wychwood Park story within a broader trope that naturalizes the idea that Canadian society is the product of the efforts of settler ancestors - independent white men whose vision for (and labour towards) our current time continues to guide contemporary social life. Not only does the trope of inheritance invite contemporary Canadians to identify with settlers as family members, but histories that rely on genealogical tropes also impose a teleology on the settler colonial process. As Cynthia Sugars argues, narrating genealogical histories "lures one into seeing things as pre-destined...it enables a turning of chance into destiny." ${ }^{, 18}$ Telling the story of settler colonialism as a family history intensifies the naturalization of settler colonial society in appropriated lands.

\section{Building a Usable Past: Recent Wychwood Park History (1980s and 1990s)}

Upon being designated as historical, the Wychwood Park neighbourhood became primarily associated with its early-twentieth-century residents. Not only was the role of Matthews as a founding figure emphasized, but the fact that many early residents were art and cultural workers was similarly accentuated in public histories.

In 1988, residents organized a centennial celebration of the Park's founding, where they deliberately positioned themselves as inheritors of the early-twentieth-century vision for the community. An art exhibition titled The Joy of Wychwood was organized, featuring art from both its founding and current residents. The exhibition consisted of

\footnotetext{
${ }^{18}$ Cynthia Sugars, "Repetition with a Difference: The Paradox of Origins in Alistair MacLeod's No Great Mischief" Studies in Canadian Literature/Etudes en Literature Canadienne, 33 no. 2 (2008):146-7.
} 
photographs, historical miscellany, and paintings produced by past and present

Wychwood residents. A catalogue of the exhibition was produced, and proceeds from the sale of it went to support the costs of restoring a portrait of Marmaduke Matthews, painted by George Reid. As the heritage plaque at the entrance to the Park points out, Marmaduke Matthews is credited with the founding of Wychwood Park as an artists' community. George Reid is the most famous painter to have lived in the Park. The portrait, therefore, was an important symbol of Wychwood Park as a centre of artistic significance in Toronto. The portrait was restored in order to be displayed in the local public library, an Arts and Crafts structure funded by a Carnegie grant and designed by Wychwood architect Eden Smith, opened to the public in 1916.

The exhibition catalogue included a lengthy biographical profile of Marmaduke Matthews, arguing that the Park now stands as "a lasting monument to a gentleman whose vision and foresight have stood the test of time." ${ }^{, 19}$ Matthews is named as one of the "forefathers" of the Park, a community that his biographers maintain "is very much and in many ways as it was meant to be. ${ }^{20}$ Matthews's efforts are described in a way that suggests they have literally made history - the present becoming a product of settler intention. Within the catalogue, commemorations of the Park's history discursively construct past residents as prescient leaders, whose geographical imaginations created the Wychwood Park current Torontonians now enjoy. This framing functions to fortify a sense of settler lineage and inheritance - linking past to present through the foresight of an inspired English artist who came to Canada with a vision for a new world. In this way, contemporary Torontonians were encouraged to identify with Matthews and position

\footnotetext{
${ }^{19}$ Keith Miller and Albert Fulton, The Art of Wychwood: Catalogue of the Art on Display During the Joy of Wychwood Centennial Exhibition (Toronto: Wychwood Park Archives, 1988), 95.

${ }^{20}$ Miller and Fulton, The Art of Wychwood, 107.
} 
themselves as inheritors of his cultural and geographical legacy. Not only does this narrative strengthen Wychwood Park's significance within Toronto's cultural history, but it also serves to reinforce settler history as a whole. For instance, Wychwood Park's history begins at the moment of Matthews' ownership of the land, with its notoriety entirely dependent upon Matthews' presence on the land, and contemporary Torontonians encouraged to identify thankfully with Matthews as a settler ancestor. Patrilineal inheritance and settler male social citizenship are normalized within this narrative. Indigenous history, land claim, and land use are rendered irrelevant through this genre of settler storytelling. Fundamentally, these discursive themes situate settler space as a white masculine sphere of social and economic participation.

The Joy of Wychwood was a celebration of the history of art of Wychwood Park, and by extension, of settler colonial history. Current and past residents submitted their paintings and stories about Wychwood Park, which were exhibited alongside archival photographs of the Park and surrounding area, as well as paintings by professional artists who lived in Wychwood Park at the turn of the twentieth century. An example from the catalogue is by Geoffrey Bonnycastle, who painted Winter in Wychwood (oil on board, 1976). His mother, Mary, provides the explanation: "This painting was executed by Geoffrey a few days before Christmas, 1976, when he was fourteen years old. He looked out and saw that there had been a heavy snowfall during the night, which had covered everything with a blanket of fluffy snow. So he painted his grandparents' house (\#9) as seen from the window of his parents' house (\#81), and presented the picture to his astonished grandparents as a charming Christmas present.".21

\footnotetext{
${ }^{21}$ Mary Bonnycastle, "Winter in Wychwood by G.M.K. Bonnycastle," in Miller and Fulton, Art of Wychwood, 26.
} 
On the subsequent page, the history of the Bonnycastle family is offered, establishing their Ontario lineage back to Sir Richard Bonnycastle, a Lieutenant Colonel in the Royal Engineers knighted for his service in Kingston during the Rebellion of 18371838. His gravestone is incorporated into the wall of St. Paul's Church in Kingston, where he died in 1847. A memorial plaque marks his bedroom at Fort Henry, where his belongings form part of the museum exhibit. Richard H.G. Bonnycastle, Geoffrey's greatuncle, "spent his early years, believe-it-or-not, as a trader for the Hudson Bay Company, and his 'Arctic Diaries' have recently been published."22 Having established the Wychwood Park community as culturally significant to Toronto's history, late-twentiethcentury residents of the Park documented their own genealogical history, positioning their belonging in Wychwood Park in relation to broader historical events relevant to the settler colonial presence in the region. In Canada and especially Ontario, genealogy is used as one of settler colonialism's tools to legitimize presence on and entitlement to the land based on ancestry. The trope of inheritance serves to indigenize settlers to the area, as well as to legitimize the notion of North American land as private property.

In addition to the genealogies of contemporary residents, The Joy of Wychwood included in-depth local research about Wychwood Park, including biographical information about high-profile early residents like George Reid and Mary Hiester Reid, Eden Smith, Gustav Hahn, Charles Currelly, Marmaduke Matthews, and Mary Wrinch. Photographs of the Park were lent by Gustav Hahn's daughter, Sylvia Hahn, who also loaned a painting of her father's for the exhibition, in addition to many old photographs of her childhood in the Park. Sylvia Hahn wrote a brief history of her family's relationship to the Park, which follows Gustav Hahn's obituary in the catalogue. A painting by Mary

\footnotetext{
22 "Geoffrey Bonnycastle," in Miller and Fulton, Art of Wychwood, 27.
} 
Hiester Reid, Woodland Interior with Blue Delphiniums and Other Flowers, was included in the catalogue, with a note from Mrs. Olwen Owen Walker, who wrote: "Having grown up in this garden, and especially lain in bed at night watching these pine trees, when this painting came up for sale, and I was married and moving away, I just had to buy it so I could still look on this lovely scene." ${ }^{23}$ Beneath the image of Hiester Reid's painting is a photograph of the same scene in the Park, demonstrating Hiester Reid's skill at naturalistic representation. Importantly, the catalogue notes, "A photograph of the same view as in [the painting] ... 73 years after Mrs. Reid recorded the scene. The flagstone path can be seen in the foreground." 24

The catalogue draws a direct connection between the founders of the Park and its 1980s-era residents, constructing the Park as a site of "timelessness" where history comes alive. Implicitly, The Joy of Wychwood and its catalogue invites readers (if not residents) to understand themselves as walking through what may as well be Mary Hiester Reid's Wychwood Park - a landscape just as familiar in 1915 as it was in 1988. This narrative device positions early Park residents as common ancestors, but more importantly introduces a compelling affect of nostalgia and familiarity between past and present which serves to promote settler histories, culture, and ways of knowing. Olwen Walker was the middle daughter of Eric and Sheila Owen, founding residents of the Park who lived in an Eden Smith-designed house. That a former resident who grew up in the Park would purchase the painting as a nostalgic souvenir of home is an important reminder of the sentimental dimension of the historical narrative produced about Wychwood Park in the 1980s.

\footnotetext{
${ }^{23}$ Miller and Fulton, Art of Wychwood, 78.

${ }^{24}$ Miller and Fulton, Art of Wychwood, 78.
} 
Several paintings of Marmaduke Matthews were included in the exhibition, including Figures in the Valley, Rockies (n.d.) from the private collection of residents Albert and Emily Fulton, and Boy on Croquet Lawn (1880) from the private collection of resident Murray Wilton. The ownership of these paintings again demonstrates the significance of the Wychwood Park community in the 1980s. Residents established themselves as local historians and art collectors, documenting the early days of their neighbourhood and creating a market and broader cultural interest in the art produced by early Park residents. By doing so, late-twentieth-century Park residents situated their neighbourhood as significant to Toronto's history, and therefore Ontario's history. Cultural events and practices such as the historical commemoration described above represent one way that settler cultural identity begins to express itself in relation to the landscape.

Formalizing Wychwood Park's historical narrative in the 1980s gave a cultural identity and sense of lineage to late-twentieth-century residents. The shared identity that 1980s-era residents were encouraged to adopt is an example of how settler colonial society relies on a relationship to the land in order to build a sense of belonging. This sense of territorial identification is what Emma Battell Lowman and Adam Barker describe as settler indigenization - a process whereby settler colonial society indigenizes itself to the colonial territory, investing in origin stories and cultural practices that build settler community while disavowing Indigenous life, land use, and land claim. I will explore the concept of settler indigenization in later parts of this dissertation, particularly Chapters Four and Five. The ways in which Wychwood Park's history has been constructed bear significance for how settler cultural identification continues to be 
expressed in Toronto, and the ways Wychwood Park is invoked as a sphere of cultural influence.

\section{Existing Research}

In this dissertation I map how Wychwood Park is both a reflection of and participant in settler colonial ways of being and knowing. My study examines the role of Wychwood Park's landscape in naturalizing the racialized social relations that function in the settler colony of Canada. In taking this approach, I address two main gaps in existing literature on Wychwood Park: the lack of research into the cultural geography of Wychwood Park, and the lack of attention paid to the racialized context in which Wychwood Park took shape.

To date, there are no studies that survey the cultural geography of the Park, nor academic studies that focus on the Park as a place. Instead, research has focused on the lives and professional contributions of early residents. My study, therefore, expands the scope of existing research to include the landscape itself as a social actor in the Park's historical, cultural, and political significance. The second contribution I make to existing literature on Wychwood Park is my research emphasis on settler colonialism and racialized social relations. No studies of the Park's residents have connected the Park to its settler colonial context nor the racialized social relations that stem from settler colonialism. In this way, my dissertation contributes a broadened understanding of the Park and its context. 
Local historians have documented the history of the Park's founding and original governance structure. ${ }^{25}$ Survey texts of Canadian art or the Canadian Arts and Crafts Movement mention Wychwood Park briefly as an Arts and Crafts-inspired neighbourhood that housed important artists. ${ }^{26}$ Existing research on Wychwood Park documents the working lives of its early residents. Artists Marmaduke Matthews, George A. Reid, Mary Hiester Reid, artist and designer Gustav Hahn, and architect Eden Smith have received the most academic attention. These Wychwood Park residents sustained personal artistic practices at the turn of the twentieth century, while collaborating with one another on a variety of initiatives to establish an art training and exhibitionary apparatus for Canada. Histories of organizations like the Royal Academy of Arts, ${ }^{27}$ the Ontario Society of Artists, ${ }^{28}$ the Arts and Letters Club, ${ }^{29}$ and the Royal Ontario Museum ${ }^{30}$ mention Wychwood residents and the contributions they made to the cultural life of Toronto while living in the Park. In studies of the Canadian Arts and Crafts Movement, Wychwood Park is mentioned as a site of architectural significance, and as a place where

${ }^{25}$ Keith Miller, The History and Development of Wychwood Park 1888-1918 (self-pub., Toronto, 1981); Wychwood Park Heritage Conservation District Plan; Margot Teasdale, "Preservation Planning with Conservation Districts with Special Reference to Wychwood Park, Toronto" (Master's thesis, Faculty of Environmental Studies, York University, 1984); Miller and Fulton, The Art of Wychwood.

${ }^{26}$ See in particular Robert James Belton, Sights of Resistance: Approaches to Canadian Visual Culture (Calgary: University of Calgary Press, 2001); Katharine A. Lochnan, Douglas E. Schoenherr, and Carole Silver, eds., The Earthly Paradise: Arts and Crafts by William Morris and His Circle from Canadian Collections (Toronto: Art Gallery of Ontario, 1993); Charles Hill, ed., Artists, Architects, \& Artisans: Canadian Art 1890-1918 (Ottawa: National Gallery of Canada, 2013).

${ }^{27}$ Rebecca Sisler, Passionate Spirits: A History of the Royal Canadian Academy of Arts 1880-1980 (Toronto: Clarke, Irwin, 1980). See also Hugh Jones, in collaboration with Edmund Dyonnet, History of the Royal Canadian Academy of Arts (self-pub., Toronto, 1934), available at http://rca-arc.ca/wpcontent/uploads/2013/12/R.C.pdf

28 Joan Murray, Ontario Society of Artists: 100 Years (Toronto: Art Gallery of Ontario, 1972).

${ }^{29}$ Margaret McBurney, The Great Adventure: 100 Years at the Arts and Letters Club. (Toronto: Arts and Letters Club, 2007).

${ }^{30}$ Lynne Teather, The Royal Ontario Museum: A Prehistory 1830-1914 (Toronto: Canada University Press, 2005). See also Charles Currelly's autobiography, I Brought the Ages Home (Toronto: Ryerson Press, 1956), which documents the early days of the Royal Ontario Museum. 
Canadian Arts and Crafts Movement proponents lived. ${ }^{31}$ Discursive studies of how Arts and Crafts ideas were adopted and put into practice by civic organizations like the Toronto Guild of Civic Art and the School Art Leagues reference Wychwood residents as central actors. ${ }^{32}$

In conventional settler histories, Canada's national story is framed as a developmental trajectory from uncultured, colonial beginnings in the nineteenth century towards independence and cultural refinement in the twentieth century. This narrative is echoed in the ways that Wychwood Park residents have been studied - as harbingers of Canada's national development.

The work lives of early Wychwood Park residents, like the organizations they belonged to, took place during a significant time in Canadian cultural history. At the turn of the twentieth century, there was an intensification of settler cultural development in Canada as major arts organizations, institutions, and nationalist art movements were formed. The period from 1890-1918 has been described as Canada's "first true boom years," ${ }^{33}$ marked by "optimism and a spirit of national pride" for the "coming of age for the young nation. ${ }^{34}$ Charles C. Hill has argued that at the turn of the twentieth century, urban growth (tied to immigration and industrialization) created a need for expanded church, bank, and government buildings - all of which engaged the labour of artists,

\footnotetext{
${ }^{31}$ Key texts on the Canadian Arts and Crafts Movement include: David Latham, ed., Scarlet Hunters: PreRaphaelitism in Canada (Toronto: Archives of Canadian Art and Design, 1998); Ellen McLeod, In Good Hands: The Women of the Canadian Handicrafts Guild (Montreal: McGill University Press, 1999); Lochnan, Schoenherr, and Silver, Earthly Paradise.

${ }^{32}$ See in particular Phillip G. Mackintosh " "The Development of Higher Urban Life' and the Geographic Imagination: Beauty, Art, and Moral Environmentalism in Toronto, 1900-1920," Journal of Historical Geography 31, no. 4 (2005): 688-722; E. Lisa Panayotidis "The Complexity of 'Seeing' and Doing 'Good': A Canadian Art Education Analysis of the 'Good Society," Canadian Review of Art Education 29, no. 2 (2002): 1-18.

${ }^{33}$ Marc Meyer, "Preface," in Hill, Artists, Architects, \& Artisans, 7.

${ }^{34}$ Charles C. Hill, "Introduction," in Hill, Artists, Architects, \& Artisans, 14.
} 
architects, and artisans. ${ }^{35}$ The expansion of the railway through western Canada created the demand for new stations and hotels to be designed and decorated. Increased private (urban, industrial) wealth created patrons who commissioned houses and interior decorations. Many Canadian artists and architects, Wychwood Park residents included, established their artistic careers in the context of the economic expansion created by the expansion of the settler colonial project. Consequently, existing research about Wychwood Park recapitulates conventional settler colonial narratives about Canada's national development and growth.

Many of Wychwood Park's famous early residents were born around the time of Confederation, and were trained in art, architecture, or design outside of the country.

A generation older than the rest of the now-famous Wychwood Park residents, Marmaduke Matthews was born in England and immigrated to Canada in 1860 at the age of twenty-three, settling in Toronto and working as a photographic painter. Matthews had studied art at Oxford prior to immigrating to Canada, and was one of the founding members of the Royal Canadian Academy of Arts and of the Ontario Society of Artists.

George Reid was born to a farming family in Wingham, Ontario and moved to Toronto at the age of eighteen in 1878 to pursue night classes in art while working during the day as a mechanic. In order to pursue his skill in painting, Reid moved to Philadelphia and trained under American painter Thomas Eakins. There he met Mary Hiester, whom he would marry in 1885 . George and Mary Reid then travelled to Europe to study art before returning to Canada in 1890. In 1891, George Reid began teaching at the Ontario College of Art.

\footnotetext{
${ }^{35}$ Hill, "Introduction," 15.
} 
Eden Smith immigrated to Canada from England in 1885 at the age of twenty-six in order to homestead in Manitoba. After two years of failed farming, Smith and his family moved to Toronto, where he began immediate work as a draughtsman, putting his English architectural training to use.

Gustav Hahn was part of a large artistically trained German family, and immigrated to Canada 1888 at the age of twenty-two, quickly finding work as a designer for an interior decoration firm with large-scale commissions such as the Ontario Legislature, the Grand Opera House, and the Chester Massey House.

Early Wychwood Park residents were mostly immigrants to Canada who had been working in the expanding arts sectors for a decade by the time they moved into the Park. Over the course of their working lives, they witnessed and contributed to a professionalization of the arts in Canada, a process that took place in chronological lockstep with nation-building efforts and westward colonial expansion. In art historical studies, scholars consistently refer to the early Wychwood Park residents as transitional figures in Canadian cultural history who bridged (colonial) tradition with (nationalist) Canadian identity.

Little has been written on Marmaduke Matthews, though he is consistently credited in art historical surveys with being the mastermind behind the establishment of Wychwood Park. Dennis Reid briefly mentions the fact that Matthews was one of the artists granted free train travel to the west coast by the Canadian Pacific Railway (CPR) in exchange for painting Rocky Mountain scenes in his examination of Canadian landscape 
artists in the late nineteenth century. ${ }^{36}$ While Matthews did participate in the CPR program for artists, he is largely overlooked as a major Canadian landscape painter of his time. The only other academic source citing the art of Marmaduke Matthews is Elizabeth Wilton's essay on Matthews's landscape paintings, which argues that he should be recognized as a significant painter in Canadian art history. Wilton argues that Matthews's paintings reflect changes in Canadian society in the late nineteenth century, and that his images of mountain landscapes were "not merely colonial fragments of the mother country's culture," but rather "responses to the land and society." ${ }^{, 37}$ In this way, Wilton argues for Matthews to be recognized as a significant contributor to the development of Canadian art as a nationalist project distinct from colonial precedents. Importantly, Wilton grew up in Wychwood Park, and her study of Matthews contributes as much to a broader understanding of his work as it does to the tradition of inheritance carried on by late-twentieth-century Park residents to recognize early Park residents as cultural relatives.

Architect Eden Smith is also credited with joining old and new aesthetic traditions. Two biographical studies of Smith exist. Carolyn Neal published a biography of for the Architectural Conservancy of Ontario, ${ }^{38}$ in which she describes Smith as "handsome, tall and of aristocratic bearing; a prototype of the Imperialist Englishman”39 who arrived in Toronto in 1896 and found that "the domestic architecture of the day in

\footnotetext{
${ }^{36}$ Dennis Reid, "Our Own Country Canada": Being an Account of the National Aspirations of the Principal Landscape Artists in Montreal and Toronto, 1860-1890 (Ottawa: National Gallery of Canada, 1978).

${ }^{37}$ Elizabeth Wilton, “'Cloud-Bound': The Western Landscapes of Marmaduke Matthews," in A Few Acres of Snow: Literary and Artistic Images of Canada, ed. Paul Simpson-Housely and Glen Norcliffe (Toronto: Dundurn Press, 1992), 241.

${ }^{38}$ Carolyn Neal, Eden Smith, Architect, 1858-1949: A Biography Prepared for the Architectural Conservancy of Ontario Toronto Region Branch (Toronto: The Conservancy, 1976).

${ }^{39}$ Neal Eden Smith, 12.
} 
Toronto he felt lacked taste and style. ${ }^{, 40}$ In response, Smith worked enthusiastically to bring British designs to Toronto, a practice Douglas Brown argues established him as “Toronto's Arts and Crafts Architect." ${ }^{41}$ Brown authored a study of Smith's life and work ${ }^{42}$ as well as a listing of his buildings and clients. ${ }^{43}$ Annmarie Adams has studied Smith's designs as uniquely Canadian for their ability to translate British designs into a colonial context, which enabled Smith to be considered a "link between English and Canadian culture," ${ }^{44}$ adapting "English architecture to American requirements.",45 Contextualizing the architecture designed for Wychwood Park, Adams argues, "The complete dependence on British forms in both the architecture and planning of Wychwood Park was one of the last major gasps of British cultural authority in early $20^{\text {th }}$ century Toronto. ${ }^{46}$ Shortly after Wychwood Park's iconic houses were built, artists and architects began working towards producing more clearly defined Canadian aesthetics that were less attributable to English referents. Wychwood Park, and Eden Smith's contributions to it, are constructed as being located in a liminal moment in Canadian cultural history - between colonial and nationalist movements in art and architecture.

The majority of art historical attention to Wychwood residents has been paid to the life and art of George Reid. ${ }^{47}$ Two exhibitions have focused on Reid's art: Chris

\footnotetext{
${ }^{40}$ Neal, Eden Smith, 8.

${ }^{41}$ W. Douglas Brown, "The Arts and Crafts Architecture of Eden Smith," The Journal of Pre-Raphaelite Studies 6/7 (Fall-Spring 1997-8): 147-60.

${ }^{42}$ W. Douglas Brown, Toronto Architect Eden Smith: Toronto's Arts and Crafts Architect (self-pub., Mississauga, 2003).

${ }^{43}$ W. Douglas Brown, Toronto Architect Eden Smith: His Buildings and Clients (self-pub., Mississauga, updated May 2006).

${ }^{44}$ Annmarie Adams, "Eden Smith and the Canadian Domestic Revival," Urban History Review 21, no. 2 (1993): 112.

45 Adams, "Eden Smith," 113.

${ }^{46}$ Adams, "Eden Smith," 110.

${ }^{47}$ Muriel Miller Miner, G.A. Reid, Canadian Artist (Toronto: Ryerson Press, 1946). Miner's biography was revised and re-released with a catalogue listing of Reid's paintings in 1987 with the title George Reid: A Biography (Toronto: Summerhill Press, 1987).
} 
Dickman's G.A. Reid: Toward a Union of the Arts ${ }^{48}$ in 1985 offered a retrospective of Reid's art practice and his influences, and Christine Boyanoski's Sympathetic Realism: George A. Reid and the Academic Tradition, in $1986,{ }^{49}$ focused specifically on how his training was evident in the subjects he pursued. Rosalind Pepall's research into Reid's pioneer murals painted in the Toronto Municipal Buildings ${ }^{50}$ situated Reid's mural work in the context of his travels to Europe and exposure to public mural schemes in France and England. Reid's promotion of the mural movement in Canada was also explored by Loren Lerner's research into Reid's Ave Canada and Gustav Hahn's Hail Dominion, both studies used to propose a mural scheme for the entrance hall of Canada's Parliament Buildings. ${ }^{51}$ Studies of Reid's nationalist public mural schemes fail to mention the ideological function pioneer scenes played in promoting a settler colonial narrative of Canada. This omission in existing research is significant, as Reid's pioneer scenes were being painted at the height of Indigenous territorial dispossession in western Canada.

To date, there are no scholarly studies of Gustav Hahn. He is mentioned in studies of initiatives he collaborated with others on (such as George Reid's proposed mural scheme for the Canadian Parliament Buildings), but no solo exhibitions nor biographical studies have been undertaken. In part, this reflects the fact that his papers are held privately, and are not available for public study. Anti-German discrimination during the

${ }^{48}$ Chris Dickman, G.A. Reid: Toward a Union of the Arts (Durham, ON: Durham Art Gallery, 1985).

${ }^{49}$ Christine Boyanoski, Sympathetic Realism: George A. Reid and the Academic Tradition (Toronto: Art Gallery of Ontario, 1986).

${ }^{50}$ Rosalind Pepall, "The Murals in the Toronto Municipal Buildings: George Reid's Debt to Puvis de Chavannes," The Journal of Canadian Art History 9, no. 2 (1986): 142-61, and Rosalind Pepall, "The Murals by George A. Reid in the Toronto Municipal Buildings" (Master's thesis, Concordia University, 1982).

${ }^{51}$ Loren Lerner, "Canada Receiving the Homage of Her Children: George Reid's Ave Canada and Gustav Hahn's Hail Dominion: A Proposal of Murals for the Entrance Hall of Canada's Parliament Buildings," Journal of Canadian Art History 29, no. 1 (2008): 50-86. Lerner further explored this subject in "George Reid's Paintings as Narratives of a Child Nation," in Depicting Canada's Children, ed. Loren Lerner (Waterloo: Wilfred Laurier University Press, 2009), 325-46. 
First World War cost Hahn his job at the Ontario College of Art, and he left Toronto with his family to farm for a number of years before returning to the college in the 1930s. This interruption to his art career undoubtedly inhibited his capacity to produce art for several significant years, which may also inform the surprisingly limited record of academic publication on his work.

Brian Foss and Janice Anderson's exhibition catalogue for Quiet Harmony: The Art of Mary Hiester Reid ${ }^{52}$ offers the only academic study of Mary Hiester Reid in her own right. In Quiet Harmony, Mary Hiester Reid is portrayed as a skilled and active painter, being elected a member of the Ontario Society of Artists (and becoming the second woman to sit on the organization's executive board), an associate member of the RCA, and exhibiting her paintings regularly. Hiester Reid's artistic contributions were "paradigmatic of aesthetic ideals and norms that were central to North American art in the late nineteenth and early twentieth centuries ... she summarized important aspects of her era." ${ }^{, 53}$ Hiester Reid died the year after the formation of the Group of Seven, a movement in Canadian art that would mark "a new view of the land, tied to an emerging definition of Canadian-ness," against which Hiester Reid's scenes of “confined domesticated scenery ... and soothingly arcadian atmosphere" would mark her as an artist "from an earlier age." ${ }^{54}$ Like her neighbours, Hiester Reid is portrayed as an artist working on the cusp of a transformation in Canadian artistic consciousness.

In the study of art, the progressive narrative of Canada's maturity relies on art as a signifier for the stage and quality of national development. Wychwood Park residents,

\footnotetext{
${ }^{52}$ Brian Foss and Janice Anderson, eds., Quiet Harmony: The Art of Mary Hiester Reid (Toronto: Art Gallery of Ontario, 2000).

${ }^{53}$ Brian Foss, "Sympathetic Self-Expression: Mary Hiester Reid and Aesthetic Ideals," in Foss and Anderson, eds., Quiet Harmony, 80-1.

${ }^{54}$ Foss, "Sympathetic Self-Expression," 85.
} 
and their like-minded contemporaries, believed that establishing a national art tradition would strengthen the nation of Canada. The narrative of historical progress has also served as the premise upon which research about Park residents has been conducted. Within existing literature on Wychwood Park, Canada's development as a nation-state is framed as an inevitability, and early Park residents are characterized as prescient historical cultural leaders who set the stage for the conditions of national cultural production Canadians take for granted today.

\section{Critical Approaches to Canadian Studies}

This orientation to Canadian cultural history is contested by critical scholars, who argue that the idea of Canada is a construction of colonial social and political processes. As Himani Bannerji argues, "Canada cannot be taken as a given. It is obviously a construction, a set of representations, embodying certain types of political and cultural communities and their operations. ${ }^{, 55}$ Conceptualizing the Canadian nation as a set of representations echoes Edward Said's contention that "Nations are narrations. The power to narrate, or to block other narratives from forming and emerging, is very important to culture and imperialism." ${ }^{, 56}$ Themes of inclusion and exclusion dominate the study of nations as imagined communities, or what Bannerji has described as the examination of "whose imagination is advanced as the national imaginary." $" 57$ Through national

\footnotetext{
${ }^{55}$ Himani Bannerji, "Geography Lessons: On Being an Insider/Outsider to the Canadian Nation," in Unhomely States: Theorizing English Canadian Postcolonialism, ed. Cynthia Sugars (Toronto: Broadview Press, 2004), 290.

${ }^{56}$ Edward Said, Culture and Imperialism (New York: Vintage Books, 1993), xiii.

${ }^{57}$ Bannerji, "Geography Lessons," 290. Emphasis in original.
} 
narratives, some subjects are, in Sunera Thobani's words, "exalted"58 as normative while some are minoritized as "others." Critical Canadian Studies scholars understand late nineteenth-century nation-building rhetoric and the expansion of Canadian control through the western territories as a time characterized by the "failure of the Canadian government to meet its treaty obligations and its decision to use food as a means to control the Indian population to meet its development agenda rather than as a response to a humanitarian crisis." ${ }^{59}$ Nation-building, for critical Canadian Studies scholars:

involved more than the construction of transcontinental railways ... it also entailed facilitating the development of a morally and physically healthy settler population, and later a citizenry based on "love and loyalty to Canada and the British Empire." This meant that those at the helm of the colonial, then dominion states ... drew from British imperial and home-grown philosophies about the appropriate character, physical appearance, roles and behaviour of settler women and men. ${ }^{60}$

Critical Canadian Studies scholars understand the nation-building rhetoric popular at the turn of the twentieth century to be one of the ways that colonial power was consolidated and secured. Many argue the development of Canadian national identity has not been a history of optimism and pride, but rather the development of an identity premised upon colonial violence, Indigenous dispossession, and structural racism waged against nonwhite immigrants and refugees. ${ }^{61}$ Consequently, critical Canadian Studies scholars have

${ }^{58}$ Sunera Thobani, Exalted Subjects: Studies in the Making of Race and Nation in Canada (Toronto: University of Toronto Press, 2007).

59 James Daschuk, Clearing the Plains: Disease, Politics of Starvation, and the Loss of Aboriginal Life (Regina: University of Regina Press, 2013).

${ }^{60}$ Daiva Stasiulus and Radha Jhappan, "The Fractious Politics of a Settler Society: Canada," in Unsettling Settler Societies: Articulations of Gender, Race, Ethnicity and Class, ed. Daiva Stasiulus and Nora YuvalDavis (London: Sage Publications, 1995), 97.

${ }^{61}$ Sherene Razack, Race, Space, and the Law: Unmapping a White Settler Society (Toronto: Between the Lines Press, 2002); Elizabeth Furniss, The Burden of History: Colonialism and the Frontier Myth in a Rural Canadian Community (Vancouver: UBC Press, 1999); Bonita Lawrence, "Real” Indians and Others: Mixed-Blood Urban Native Peoples and Indigenous Nationhood (Lincoln: University of Nebraska Press, 2004). 
studied Canadian identity as an ideological means by which racialized violence is normalized and perpetuated. ${ }^{62}$

There is a robust literature by feminist scholars that has established the premise that colonial processes involved the production and performance of social identities articulated through categories of race, class, and gender. ${ }^{63}$ This literature understands colonialism to be an inherently gendered and racialized process. One of the patterns that emerges within studies of power and colonialism is that "white men ... made and enforced laws and policies in their own interests" in colonial contexts. "Marital laws, property laws, land laws and the intractable violence of male decree bound [settler women] in gendered patterns of disadvantage and frustration. The vast, fissured architecture of imperialism was gendered throughout." ${ }^{, 64}$ In Canada, the patriarchal family system was central to the establishment of the settler colonial land economy. The elimination of Indigenous land title functioned not only to transfer wealth from Indigenous communities to settler communities; the settler land economy transformed Indigenous territory into commodified zones of patrilineal inheritance. Settler colonialism was a process whereby private, intergenerational wealth could be generated from "free" land. Therefore, the concept of patrilineal inheritance was central to long-term settler colonial economic participation.

\footnotetext{
${ }^{62}$ In addition to Exalted Subjects, see Rinaldo Walcott, Black Like Who? Writing Black Canada (Toronto: Insomniac Press, 1997); Himani Bannerji, The Dark Side of the Nation: Essays on Multiculturalism, Nationalism, and Gender (Toronto: Canadian Scholars Press, 2000); Richard Day, Multiculturalism and the History of Canadian Diversity (Toronto: University of Toronto Press, 2000).

${ }^{63}$ Ann Laura Stoler, Race and the Education of Desire: Foucault's History of Sexuality and the Colonial Order of Things (Durham, NC: Duke University Press, 1995); Anne McClintock, Imperial Leather: Race, Gender, and Sexuality in the Colonial Contest (New York: Routledge, 1995); Vron Ware, Beyond the Pale: White Women, Racism, and History (London: Verso, 1992); Adele Perry, On the Edge of Empire: Gender, Race, and the Making of British Columbia 1849-1871 (Toronto: University of Toronto Press, 2001).

${ }^{64}$ McClintock, Imperial Leather, 6.
} 
Patrilineal inheritance reveals settler colonialism as a masculinizing process, and the frontier as a site of masculine self-actualization. Settler colonialism as an economic and spatial system invited settler men to literally rename the land after their family names, and become governors of their land and their family. The story of Canadian patriarchal social organization is a story that is embedded within the settler colonial process. The institution of the patriarchal family ensured its continuity through the transmission of private property that was held almost exclusively by men. Land ownership was the first criterion used to establish a voting class in Canada. Therefore, men became citizens through their access to land ownership. The settler colonial land economy facilitated the political autonomy of land-owning men while simultaneously recognizing women as dependents. While settler families worked to build intergenerational wealth through agriculture on appropriated land, colonial policy toward Indigenous people was focused on disrupting existing kinship systems and imposing patriarchal and patrilineal inheritance and governance systems.

Colonialism has been traditionally defined as "the conquest and control of other people's land and goods. ${ }^{, 65}$ Rinaldo Walcott argues that critical Canadian Studies understands that "colonial projects are not only intrusive but incorporative ... coloniality's most profound operations work at the level of what it means to know, and how knowing places some bodies out of place. ${ }^{, 66}$ Colonial logics reproduce themselves because, as Walcott cautions, "the colonial project of Canada is skilled at producing what can too easily appear to be non-relational dynamics." ${ }^{, 67}$

\footnotetext{
${ }^{65}$ Ania Loomba, Colonialism/Postcolonialism (London: Routledge, 1998), 2.

${ }^{66}$ Rinaldo Walcott, "Foreword," in Critical Inquiries: A Reader in Studies of Canada, ed. Lynn Caldwell, Darryl Leroux, and Carianne Leung (Halifax: Fernwood, 2013), 5.

${ }^{67}$ Walcott, "Foreword," 4.
} 
Existing literature does not mention Wychwood Park as an actor in settler colonial structures. I argue that this omission is an example of Walcott's notion of seemingly nonrelational dynamics. In order to situate Wychwood Park's relationship to settler colonialism when it appears not to have one, I rely on the conceptual tools developed by critical landscape and critical whiteness scholars.

\section{Plan of Dissertation: Elimination, Indigenization, Transcendence}

In the last decade, settler colonial studies has emerged as a sub-field of postcolonial scholarship. Within the conventions of post-colonial scholarship, colonialism is traditionally understood to imply the imposition of foreign rule on an Indigenous population. settler colonial studies scholars theorize the particular expressions of power that are unique to settler colonial contexts. ${ }^{68}$ It is important to emphasize that settler colonial societies have been organized in diverse ways, producing various models of social and political organization. ${ }^{69}$ My discussion in this section will centre the features of settler colonial societies that are applicable to the Canadian context, as a way of framing my examination of Wychwood Park. It is important to note that my focus replicates a

${ }^{68}$ James Belich, Replenishing the Earth: The Settler Revolution and the Rise of the Angloworld (Oxford: Oxford University Press, 2009); Coulthard, Red Skin White Masks; Tracey Banivanua Mar and Penelope Edmonds, eds., Making Settler Colonial Space: Perspectives on Race, Place, and Identity (London: Palgrave Macmillan, 2010); Caroline Elkins and Susan Pedersen, eds., Settler Colonialism in the Twentieth Century (New York: Routledge, 2005); Patrick Wolfe, Settler Colonialism and the Transformation of Anthropology (London: Bloomsbury, 1999); Lorenzo Veracini, Settler Colonialism: A Theoretical Overview (London: Palgrave MacMillan, 2010); Daiva Stasiulis and Nira Yuval-Davis, eds., Unsettling Settler Societies: Articulations of Gender, Race, Ethnicity, and Class (London: Sage, 1995); Paulette Regan, Unsettling the Settler Within: Indian Residential Schools, Truth Telling, and Reconciliation in Canada (Vancouver: UBC Press, 2011); Eva Mackey, Unsettled Expectations: Uncertainty, Land, and Settler Decolonization (Halifax: Fernwood, 2016); Emma Battell Lowman and Adam J. Barker, Settler Identity and Colonialism in 21st Century Canada (Halifax: Fernwood, 2015); Mark Rifkin, Settler Common Sense: Queerness and Everyday Colonialism in the American Renaissance (Minneapolis: University of Minnesota Press, 2014).

${ }^{69}$ For a more comprehensive account of different forms of settler colonization, see in particular Veracini, Settler Colonialism: A Theoretical Overview. 
limitation of the field of settler colonial studies, allowing settler power to be "the fundamental reference and assumption...imposing a view on the world that is but an outcome or perspective on that power" ${ }^{70}$ This convention in the field inadequately theorizes settler colonialism as a failed project, as evidenced by the ongoing assertion of Indigenous sovereignty, Indigenous resistance, and transnational alliances that counter settler colonial occupation. ${ }^{71}$ Settler colonialism's failures fall outside the scope of my discussion, which is limited to the application of conceptual tools from the field of settler colonial studies onto the case study of Wychwood Park.

With regards to the organization of settler colonial societies, settler colonies are different from traditional resource extraction colonies and military enclaves by being organized around the construction of a new and permanent settler society. Patrick Wolfe argues that colonies and settler colonies are premised upon different relationships with the land and Indigenous populations. In colonies, wealth is extracted from the land and the exploitation of Indigenous labour in the service of metropolitan interests. In settler colonies, settlers "come to stay" 72 and work to replace the Indigenous population as the legitimate permanent inhabitants of the land. Because of this, Wolfe argues that settler institutions and settler futurity are premised upon a "logic of elimination" with regards to Indigenous land use, land claim, and sustained Indigenous life. ${ }^{73}$ Therefore, while settler colonies do sometimes exploit the Indigenous population as a labour force, it is

\footnotetext{
${ }^{70}$ Taiaiake Alfred and Jeff Corntassel, "Being Indigenous: Resurgences Against Contemporary Colonialism" Government and Opposition 40, no. 4 (2005): 601.

${ }^{71}$ Audra Simpson engages in these ideas in Mohawk Interruptus: Political Life Across the Borders of Settler States (Durham: Duke University Press, 2014).

${ }^{72}$ Patrick Wolfe, "Settler Colonialism and the Elimination of the Native," Journal of Genocide Research 8 , no. 4 (2006): 388.

${ }^{73}$ Wolfe, Settler Colonialism; Wolfe, "Settler Colonialism and the Elimination of the Native"; Patrick Wolfe, "Land, Labor, and Difference: Elementary Structures of Race," American Historical Review 106, (2001): 865-905.
} 
Indigenous land rather than Indigenous labour that settler colonies seek to control. ${ }^{74}$ It is through the elimination of Indigenous life that settler society becomes established and ensures its permanence.

Wolfe characterizes the organization of settler colonies as a "structure, not an event,"75 highlighting settler colonialism as ongoing and not limited to one historical moment of invasion or attack. Similarly, Mark Rifkin points to settler colonial logics, which he characterizes as the "social, ideological, and institutional processes through which the authority of the settler state implicitly and explicitly is enacted."76 The notion of settler colonialism as a structure, logic, or series of processes reflects a consensus within the field that settler colonialism is "not just a legacy of earlier times, but an ongoing ideology and practice that is critical to defining the sense of both nation and self." $" 77$

Emma Battell Lowman and Adam Barker argue that settler colonial societies are built upon a "trajectory" of three interconnected goals: elimination, indigenization, and transcendence. ${ }^{78}$ I use the language of elimination, indigenization, and transcendence as a container for my analysis, though I must emphasize that Battell Lowman and Barker rely heavily on leading thinkers in the field in order to develop their outline for the study of settler colonial rule. Their framework consolidates widely cited concepts from theorists in the field and offers a model for understanding the way in which settler colonial societies are structured.

\footnotetext{
${ }^{74}$ See in particular Sarah Carter, Lost Harvests: Prairie Indian Reserve Farmers and Government Policy (Montreal: McGill-Queens University Press, 2019). Veracini also discusses this on page 8 of Settler Colonialism.

${ }^{75}$ Wolfe, "Settler Colonialism and the Elimination of the Native," 388.

${ }^{76}$ Rifkin, Settler Common Sense, 343.

${ }^{77}$ Battell Lowman and Barker, Settler Identity, 35.

${ }^{78}$ Battell Lowman and Barker, Settler Identity, 31.
} 
The three inter-related goals of settler colonial social development serve as the model for the four analytic chapters of this dissertation. Chapter Two, "Research Method and Conceptual Framework," elaborates on the conceptual tools I rely on from Critical Whiteness Studies and Critical Landscape Studies to build my argument. Further, I demonstrate how the land archives themselves reflect a form of settler colonial organized forgetting. Chapter Three, "Elimination," documents the legal and political history of the land now referred to as Wychwood Park. I situate the establishment of Wychwood Park within the context of the settler colonial land economy, an economic system premised upon Indigenous exclusion and the elimination of Indigenous land title. Chapter Four, "Settler Indigenization I," analyzes how settler indigenization can be understood through the physical landscaping of Wychwood Park. In Chapter Four, I argue that Wychwood Park's English design aesthetics were a settler colonial strategy to naturalize the British occupation of Toronto. In Chapter Five, "Settler Indigenization II," I continue my examination of settler indigenization to include moments where the Wychwood Park community has promoted a public past grounded in a discourse of patrilineal inheritance and common lineage. In Chapter Six, "Colonial Transcendence," I argue that colonial transcendence is reflected in the urban beautification efforts Wychwood Park residents have contributed to. I argue that efforts to civilize racialized immigrant neighbourhoods by providing access to green space and fine arts is an example of Ghassan Hage's notion of "white governmental power" and a component of settler colonial social life whereby white national citizenship is enacted by regulating nonwhite bodies. In Chapter Six, I argue that civic improvement efforts by Wychwood Park residents constructed the 
Wychwood Park landscape as an idealized white space of civility and model citizenship in contrast to the filthy racialized downtown core of Toronto.

In what follows, I provide an overview of settler colonial studies, summarizing the key concepts from the field and demonstrating how they fit into the tripartite framework proposed by Battell Lowman and Barker. I conclude each section by offering a brief chapter summary.

\section{Chapter Two: Research Method and Conceptual Framework}

In Chapter Two, I demonstrate how the method I used to pursue this research is informed by, and contributes to, larger methodological questions about how to undertake anti-colonial research in the humanities. I illustrate how the organization and structure of land records in different archives in Toronto facilitates settler colonial forgetting with regards to Indigenous land title. I consider the affective dimension of the land records archive, arguing that the genealogical assumptions that inform the search guides and land records index encourage researchers to identify with settler colonists as personal ancestors, intensifying the patrilineal theme operating within settler colonial knowledge production. I then introduce two key fields of literature that serve as my conceptual framework for this dissertation: Critical Landscape Studies and Critical Whiteness Studies. Concepts from Critical Landscape Studies inform my understanding that land is an actor in social life and social relationships. Critical Whiteness Studies informs my understanding of how whiteness is constructed, and how the so-called invisibility of whiteness can be rendered intelligible in critical scholarship. Together, these two fields of literature support my claim that Wychwood Park is a white settler colonial landscape. 


\section{Chapter Three: Indigenous Elimination}

By elimination, Barker and Lowman refer to the physical and cultural genocide waged by colonial powers against Indigenous communities, as well as the elimination of Indigenous land claims and political power. Patrick Wolfe argues that the logic of settler colonialism involves a "sustained institutional tendency to eliminate the Indigenous population" 79 in order to facilitate their replacement with a self-governing settler society. In order for settlers to legitimately build a new home in a colonial territory, the idea that one is in someone else's home needs to be continuously denied. Veracini argues that the colonial "encounter" is “mirrored by ... a settler colonial 'non encounter,' a circumstance fundamentally shaped by a recurring need to disavow the presence of Indigenous 'others." ${ }^{80}$ Disavowal, a practice of active denial, is a core discursive device used to legitimize the settler presence in settler colonies. A lack of information about pre-colonial history or pre-colonial land use patterns in urban centres, for instance, is a persistent feature of Canadian historical narratives. Disavowal can often be discursively articulated through silence.

Understanding a lack of information about Toronto's pre-colonial history as a colonial discourse of disavowal informed my research direction and emphasis. Disavowal functions to erase the Indigenous presence on the land, but also to erase Indigenous legitimacy to land claims or political sovereignty. Further, the research conventions that produced a silence about colonialism within existing art historical literature on Wychwood Park can be interpreted as constitutive of the logic of elimination. One of my primary research goals was to contest the epistemic silence kept with regards to

\footnotetext{
${ }^{79}$ Wolfe, Settler Colonialism, 163.

${ }^{80}$ Lorenzo Veracini, “Introducing Settler Colonial Studies," Settler Colonial Studies 1 (2011): 2.
} 
Wychwood Park's situatedness within settler colonial systems and logics. To be clear, I am less interested in why silences persist on the subject of settler colonialism within the literature; my concern is primarily grounded in how these silences are echoed by larger intellectual projects that naturalize and normalize settler colonial rule in Canada.

In Chapter Three, I document Wychwood Park's relationship to the elimination of Indigenous land title in Toronto. This chapter addresses the gap in existing research about Wychwood Park, which consistently fails to address any relationship between the Park and settler colonialism. In Chapter Three, I argue that private property was an essential feature of the settler colonial economy, and that the settler colonial economy was premised upon Indigenous exclusion. I trace the history of colonial land grants related to the territory now known as Wychwood Park, demonstrating how land granted for free was subdivided for increasing profit over several generations, resulting in the accumulation of settler wealth and the sustained manufacture of Indigenous poverty. Chapter Three argues that colonial land policies were the primary mechanism used to eliminate Indigenous land title in Toronto.

\section{Chapters Four and Five: Settler Indigenization}

These chapters address how settler societies indigenize themselves to the area, thereby replacing Indigenous society with settler society. Settler indigenization also functions to ensure a sense of belonging in the colonial landscape. Distinguishing settler colonialism from migration, Lorenzo Veracini writes, "Migrants, by definition, move to another country and lead diasporic lives, settlers, on the contrary, move ... to their 
country. ${ }^{81}$ One of the unique features of settler colonialism is the process whereby colonists participate in cultural pastimes and traditions that link their sense of identity and belonging to the colonial territory, indigenizing themselves to it. Settler colonies are designed to end not by having colonists "go back home" but instead by staying and “making home." Amanda Murphayao and Kelly Black have pointed to practices such as place-naming as forms of settler identification with the land. ${ }^{82}$ The very act of naming an area of Toronto "Wychwood Park" after a forest in Oxfordshire, England, and then erecting a historical plaque detailing the English origins of the name "Wychwood," is an example of settler indigenization built upon the logic of Indigenous elimination and the disavowal of Indigenous history and presence. Lowman and Barker argue that indigenization is a process that "defines how colonizers imagine their belonging in a place." ${ }^{\prime 83}$ Wychwood Park’s landscape design, steeped in signifiers of medieval Englishness, serves an indigenizing function. By designing the landscape to resemble rural England, Wychwood Park residents symbolically de-territorialized the landscape of its Indigenous land use and meaning, and re-territorialized it as English space.

In Chapter Four, I demonstrate how settler indigenization was achieved in Wychwood Park through landscape and architectural design. I document the process whereby the physical environment of the Park was modified to suit the landscaping vision of early residents, and I show how Arts and Crafts architectural principles were translated into the Wychwood Park context.

\footnotetext{
${ }^{81}$ Veracini, Settler Colonialism, 3.

${ }^{82}$ Amanda Murphayao and Kelly Black, "Unsettling Settler Belonging: (Re) Naming and Territory Making in the Pacific Northwest," American Review of Canadian Studies 45, no. 3 (2015): 315-31.

${ }^{83}$ Battell Lowman and Barker, Settler Identity, 25.
} 
In Chapter Five, I examine the representation of pioneer life in the art of George A. Reid, arguing that representations of male agrarian labourers constituted a nineteenthcentury cult of the pioneer in Ontario. The cult of the pioneer indigenized settler society to appropriated territories by promoting a settler origin story of male farming labour ushering in the birth of the nation. My argument highlights how settler colonial society facilitated white male economic self-actualization - offering settlers the chance to form a new line of succession. I then examine the efforts of the 1995 Wychwood Park community to preserve a mural painted by Gustav Hahn a century prior that was threatened with demolition. The mural preservation campaign relied on tropes of legacy, inheritance, and cultural regeneration. I argue that the 1995 campaign highlights the construction of settler colonial society as a genealogical project - uniting ruling classes of settlers as cultural kin.

\section{Chapter Six: Colonial Transcendence}

Lowman and Barker argue that transcendence is "[putting colonialism] in the past" by "fully [replacing] Indigenous sovereignties on the land." ${ }^{84}$ Lowman and Barker's notion of transcendence is echoed by Veracini's claim that settler colonial societies have a "persistent drive to ultimately supersede the conditions of colonial operation." ${ }^{\prime 85}$ This persistent drive can be read in the nation-building narratives of settler colonies that deny colonial futurity, instead promoting the myth of the nation as sovereign and independent from colonial rule. One of the ways that settler societies work to transcend their colonial context is by positioning settlers as civilizing agents governing the lives of non-

\footnotetext{
${ }^{84}$ Battell Lowman and Barker, Settler Identity, 31.

${ }^{85}$ Veracini, "Introducing Settler Colonial Studies," 3.
} 
Indigenous "others." Whereas post-colonial scholars like Edward Said and Johannes Fabian characterize colonial discourses as relying on binaries (self/other, west/nonwest, advanced/backwards) ${ }^{86}$ Veracini argues that settler colonies reflect a triangulated set of power relations. There are three core categories of members of a settler colonial society: the settler colonizer, the Indigenous colonized, and a heterogeneous group of immigrant "others." 87

In Canada, this triangulated set of power relations functions to institutionalize white supremacy through the creation of a class of citizens excluded from both settler and Indigenous narratives of belonging within the settler state. Sunera Thobani argues that in Canada, there is a "master narrative of the nation which takes as its starting point of departure the essentially law-abiding character of its enterprising nationals, who are presented (for the most part) as responsible citizens ... Having overcome great adversity in founding the nation, these subjects face numerous challenges from outsiders 'Indians,' immigrants and refugees - who threaten their collective welfare and prosperity." ${ }^{88}$ Institutions of the settler state - schools, police forces, social service agencies - then become mobilized to govern both Indigenous and non-white immigrant "others" who are cast as illegitimate subjects within the national mythos. Ghassan Hage calls this dynamic a reflection of "white governmental power," which is "the power to have a legitimate view concerning the position of others in the nation." 89

\footnotetext{
${ }^{86}$ See in particular Edward Said, Orientalism (New York: Vintage Books, 1978); Johannes Fabian, Time and the Other: How Anthropology Makes Its Object (New York: Columbia University Press, 1983).

${ }^{87}$ Lorenzo Veracini, “On Settlerness,” borderlands e-journal 10, no. 1 (2011): 1.

${ }^{88}$ Thobani, Exalted Subjects, 4.

${ }^{89}$ Ghassan Hage, White Nation: Fantasies of White Supremacy in a Multicultural Society (New York: Routledge, 2000), 46.
} 
In Canada, white governmental power is one of the instruments through which settler transcendence is accomplished. White governmental power naturalizes white settler populations not only as the legitimate inheritors of Indigenous lands, but as the morally responsible, racially civilized, and culturally sophisticated governors of a permanent underclass whose permanent marginalization is secured through racism. As Tracey Banivanua Mar and Penelope Edmonds argue, race is an ideological tool used in settler colonial contexts to sustain the physical reorganization of space required to facilitate Indigenous elimination. They write, "[race] has found permanent residence in settler colonial landscapes and cityscapes, where racially coded legacies continue to generate contests over the ownership and belonging of space." ${ }^{90}$ Settler colonialism's capacity to spatialize racial ideas informs my analysis of the early Wychwood Park residents' participation in urban beautification at the turn of the twentieth century. In Chapter Six, I situate Wychwood Park's landscape as a white bucolic correlative to the overcrowded, ethnic downtown core of Toronto at the turn of the twentieth century. Specifically, Wychwood Park's landscape design was informed by theories of social betterment that linked social health to aesthetic health in the life of a nation. Wychwood Park residents designed their own neighbourhood according to these principles while simultaneously applying the same principles to their work in the social reform movement - beautifying working class neighbourhoods, donating art to public schools, and designing social housing. Chapter Six argues that the beautification of working class neighbourhoods in Toronto is a reflection of settler colonialism's civilizing impulse. By engaging in civic organizations to civilize ethnic working class neighbourhoods through British aesthetics, Wychwood Park residents became positioned

\footnotetext{
${ }^{90}$ Banivanua Mar and Edmonds, Making Settler Colonial Space, 3.
} 
as "enterprising nationals," in Thobani's terms. Chapter Six argues that Wychwood Park is a white settler colonial landscape because it functioned as an idealized racial space associated with cultural refinement and leisurely land use in contrast to the ethnic working class downtown core. 


\section{Chapter Two Research Method \& Conceptual Framework}

"Good news for genealogists! You can now access more than 4,100 recently digitized patent plans on the Archives of Ontario's Visual Database. Use this great new online resource to trace your ancestors' Crown land records." 1

"Are you sure you want to search for that, honey? The land records for Toronto are an absolute mess."

"Oh you poor thing! Have you been looking for nineteenth-century records? No one here knows where they are. Here, come to this bookcase." 3

"The challenge of settler-colonial art history, as opposed to Canadian art history, is to articulate how claims to ... authority and authenticity are being wielded, by and for whom, and to disrupt their naturalization by demonstrating the ways in which they fail.".4

In his discussion of colonial state violence, with regards to the regulation of

private settler property, Nicholas Blomley argues that "violence was not only an outcome of law, but its realization." Blomley's framing of violence as a fulfilled intention rather than a mere consequence invites further consideration into settler colonial ideology as purposeful rather than reflective of broader power structures. He writes, "such violences were not simply a secondary adjunct to the discursive realm ... but were of importance in their own right as a vector of colonial power." In this chapter, I approach the land records archive in Toronto from a similar perspective. I illustrate how the organization of the land records archive serves as a vector of settler colonial power. In my Introduction, I cited Blomley's argument that cities were sites of “organized forgetting.” Municipal

\footnotetext{
${ }^{1}$ http://www.archives.gov.on.ca/en/about/patent-plans.aspx, accessed February 14, 2020.

2 Research notes, October 2013.

${ }^{3}$ Research notes, November 2013.

${ }^{4}$ Damien Skinner, "Settler Colonial Art History: A Proposition in Two Parts," Journal of Canadian Art History/Annales d'histoire de l'art Canadien 35, no. 1 (2014): 142.

${ }^{5}$ Nicholas Blomley, "Law, Property and the Geography of Violence: The Frontier, the Survey, and the Grid," Annals of the Association of American Geographers 93, no. 1 (2003): 129. Emphasis in original.

${ }^{6}$ Blomley, "Law, Property and the Geography of Violence," 129.
} 
archives are one place designed to organize settler colonial forgetting. Settler colonial rule depends upon the denial and rejection of anti-colonial evidence, arguments, social movements, and political structures. In the structure of the settler colonial land archive, the goals of settler colonial society are braided together. Indigenous elimination is reflected in the absence of territorial information prior to being declared property of the Crown. Settler indigenization depends upon the settler story, beginning with the arrival of settlers - the archive is built to tell a story of settler belonging. Finally, colonial transcendence is reflected in land documents that form part of a national heritage.

The institutionalization of forgetting expresses itself in the Toronto land records archive in a variety of ways. In my Prologue, I recounted the attitudes of front-line staff who dismissed the validity of my research into the name and political status of land prior to its being known as Crown Land. These attitudinal barriers reflected a larger system of forgetting that informed the ways documents were organized, how search aids were written, and what information was deemed worth preserving.

As I outlined in the previous chapter, my research focus on Wychwood Park's relationship to settler colonialism addresses a significant gap in existing literature on the Park. To date, there are no studies that link Wychwood Park to an analysis of settler colonialism. This omission represents an epistemic limitation of existing research methods used to study the Park, but it is also reflective of the structural organization of the archives that house documents and ephemera related to Wychwood Park's history. This chapter documents how archives related to land exchange in the Toronto area are organized to prevent a critical analysis of settler colonialism from being pursued. I then summarize the conceptual framework that I used in order to develop an anti-colonial 
research method in this dissertation. By relying on a critical theoretical framework supported by Critical Landscape Studies and Critical Whiteness Studies, I was able to work against the structure of the archive in order to pursue my research.

\section{Models of Anti-Colonial Research}

My research direction was strongly informed by Linda Tuhiwai Smith's argument that research is "inextricably linked to European imperialism and colonialism" and that "research is not an innocent or distant academic exercise but an activity that has something at stake and that occurs in a set of political and social conditions."7 Importantly, Tuhiwai Smith was writing from an Indigenous perspective, and her influential book Decolonizing Methodologies argued for an Indigenous research agenda. The majority of texts that outline a decolonizing research method have, at their core, an interest in promoting Indigenous-centred research. This focus reflects the fact that Western epistemic traditions evolved in tandem with European imperialism, and researchers have often been employed by the colonial enterprise to generate knowledge that would further imperial interests. Decolonizing methods, as an area of scholarship within critical research methods, often focus on ways of engaging non-Indigenous researchers as allies or organizing Indigenous communities to take control of a research agenda to serve their own interests. More recently, critical scholars have argued that

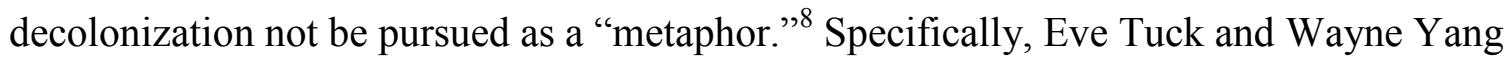
have offered an intervention into the practice of deeming anti-colonial research an effort

\footnotetext{
${ }^{7}$ Linda Tuhiwai Smith, Decolonizing Methodologies: Research and Indigenous People (London: Zed Books, 1999), 1, 5.

${ }^{8}$ Eve Tuck and K. Wayne Yang, "Decolonization is Not A Metaphor," Decolonization: Indigeneity, Education \& Society 1, no. 1 (2012): 1-40.
} 
to "decolonize." They write: "One trend we have noticed, with growing apprehension, is the ease with which the language of decolonization has been superficially adopted into education and other social sciences, supplanting prior ways of talking about social justice, critical methodologies, or approaches which decenter settler perspectives. Decolonization, which we assert is a distinct project from other civil and human rights-based social justice projects, is far too often subsumed ... with no regard for how decolonization wants something different than those forms of justice."

Tuck and Yang argue that decolonization demands more than a lens of analysis or a theoretical framework applied to teaching and research settings. The goals for my research have been to destabilize settler colonial ways of knowing, particularly the ways in which settler sensibilities and interests were taken for granted. While my approach was informed by scholars who describe their methodological frameworks as decolonial, I understand my approach to be anti-colonial.

Importantly, the majority of scholarship on decolonizing or anti-colonial research methods relates to social science research, where human participants in research projects are central to a research plan. There is a vast and dynamic field of textual interpretation that has illustrated the construction of imperial power and epistemology, led primarily by historians, literature scholars, and philosophers. Humanities research relies heavily on this literature as an interpretive framework, however, humanities scholars are less prescriptive about the method required to engage in such interpretation.

Broadly speaking, scholarship that imagines anti-colonial research methods is focused on the role that power relations play in determining how we know what we know. The social position of the researcher is considered to be as important as the questions the

\footnotetext{
${ }^{9}$ Tuck and Yang, "Decolonization," 2.
} 
researcher asks, as well as the political legacies of the academic disciplines the researcher is situated within. By way of example, Kagendo Mutua and Beth Blue Swadener list the following questions as starting points for researchers engaged in a decolonizing ${ }^{10}$ research program:

- Whose agenda is decolonizing research?

- Why might problematizing postcolonial theory be critical to decolonizing research?

- Who has the power to name, and how does naming reify existing power relations?

- Who defines and legitimizes what counts as "scholarship"?

- Where are some of the current "data plantations" in educational research?

- Is experience, particularly "Indigenous insiders' experience" a necessary precursor for asking the right questions in pursuit of culturally legitimate scholarship - or can the privileging of "insider" experience be problematic? ${ }^{11}$

Questions such as these both disrupt normative assumptions scholars are trained to have about setting a research agenda, and reflect an ambivalence about engaging with academic research in order to pursue decolonization as a political goal. The field of anticolonial research is infused with this ambivalence, questioning how politically productive working within formal structures can ultimately be. This may always be a feature of anticolonial research, a constant interrogation of shifting power dynamics that infuse the relationships between researcher and research subject.

While relationships and tangible research outcomes offer concrete fodder for exploring anti-colonial methods in social science research, the scope of applicability is far less clear in humanities research. Humanities scholars can integrate some of the conceptual tools promoted by the literature previously mentioned, but it is not entirely

\footnotetext{
${ }^{10}$ Mutua and Swadener's use of the term decolonizing reflects, I believe, the metaphorical practice Tuck and Yang critiqued in their influential article. While these research questions are essential to destabilizing colonial ways of knowing, and therefore strongly inform my research program, I concur with Tuck and Yang that they do not further the decolonial agenda per se.

${ }^{11}$ Kagendo Mutua and Beth Blue Swadener, Decolonizing Research in Cross-Cultural Contexts: Critical Personal Narratives (Albany: SUNY Press, 2004), 2-3.
} 
obvious how to claim a particular piece of research as anti-colonial, or not. Building upon one of Mutua and Swadener's earlier questions, I approach anti-colonial epistemology as an intellectual project that all scholars are invited to undertake, regardless of how the colonial system has situated their experience of social power relations.

\section{Anti-Colonial Research Methods in the Humanities}

In my search for a methodological model that could be applied to humanities research from an anti-colonial perspective, there were two models I used to guide my research. The first was Damien Skinner's model of "settler colonial art history."12 As I have established, the majority of research into Wychwood Park has been undertaken by art historians who have consistently neglected the settler colonial context in which Wychwood Park and the artistic oeuvres of its early residents were established. Skinner proposes a methodological intervention into the field, arguing for a "model for writing a new kind of art history that will actively grapple with the impact of settler colonialism on both artistic practice and art historical narratives." ${ }^{, 13}$

Skinner differentiates "settler art history" from "settler colonial art history." For Skinner, "settler art history" is "a specific variant of Western art history ... characterized by ... a desire to eliminate or assimilate the Indigenous presence, especially through the mythology of an empty land which the settlers have transformed into home; and on the other hand, an ambivalent relationship with the metropole and the cultural production of Europe, expressed through a deep investment in ideas of nationalism." ${ }^{14}$ Skinner's statement invites conventional nationalist art narratives to be named as settler narratives,

\footnotetext{
${ }^{12}$ Skinner, "Settler-Colonial Art History."

${ }^{13}$ Skinner, "Settler-Colonial Art History," 132.

${ }^{14}$ Skinner, "Settler-Colonial Art History," 141.
} 
complicit in imperial discourses that legitimize settler culture and presence in a colonial context. By doing so, Skinner invites further analysis and consideration into ways that disciplinary conventions fail to adopt oppositional positions vis-a-vis settler histories. The further analysis Skinner invites would be termed "settler colonial art history," a field, he contends, that would "articulate how claims to [conventional] authority ... are being wielded, by and for whom, and to disrupt their naturalization by demonstrating the ways in which they fail." 15

Skinner outlines ten propositions for a settler-colonial art history, one that imagines an art historical method that disrupts settler epistemologies. Skinner argues that art scholars must build stronger relationships to anthropology, acknowledging that categories of non-European art extend beyond a two-dimensional framework, and incorporate more than visual uses. Just as art historians need to approach some art works with anthropological tools, they also need to be attentive to the contributions of Indigenous analysis and expand the interpretive scope of the discipline. Skinner argues that settler and Indigenous art forms, practices, and cultures need to be studied in tandem with each other, rather than situating settler art within European traditions and Indigenous art in global traditions. Skinner imagines settler colonial art history as incorporative of psychoanalytic, transhistorical, and transnational analyses, in order to recognize that all art relates to settler colonialism. Below is the complete list of propositions put forward by Skinner:

1. Settler-colonial art history will work to destabilize existing art historical narratives

2. Settler-colonial art history will be engaged with, but not the same as, western art history and Indigenous art history

\footnotetext{
${ }^{15}$ Skinner, "Settler-Colonial Art History," 142.
} 
3. Settler-colonial art history will pay attention to both settler and Indigenous art practices, believe that these cannot, and should not, be separated

4. Settler-colonial art history will resist art history's investment in the visual

5. Settler-colonial art history will pay attention to craft (and other forms of visual culture), thus upending the hierarchy of genres that continues to hold for art history in general

6. Settler-colonial art history will be committed to escaping the limits of the nation-state

7. Settler-colonial art history, like settler colonialism, will be transnational in its focus

8. Settler-colonial art history, like settler colonialism, will be transhistorical in its focus

9. Because settler colonialism is predicated on the disavowal of foundational violence and invests heavily in the psychic mechanisms that sustain this process, settler-colonial art history will make use of psychoanalysis as a methodology

10. Settler-colonial art history recognizes that all art practices, even those that seem to have nothing to do with settler-colonial dynamics, are part of the system that maintains the interests of the settler subject. ${ }^{16}$

The strength of Skinner's argument is that its breadth encourages its adoption by art historians working in different facets of the discipline. Curiously, while Skinner acknowledges relationships to land as central to settler colonial meaning-making, his ten propositions fall short of incorporating land as an actor in an anti-colonial analysis of art and artistic production. If, as settler colonial studies has established, one's relationship to land is a fundamental aspect of settler identity and society, then a settler colonial approach to studying art must also account for the legal, aesthetic, and social aspects of land in which art is being produced, consumed, circulated, and exhibited. Therefore, my methodological approach to this topic was informed as much by efforts within the field of Art History to address gaps in existing research, as by the limitations of these efforts.

A second model of anti-colonial research that informed my thinking was Celia Haig-Brown's concept of the "decolonizing autobiography." Haig-Brown developed a storytelling model called a "decolonizing autobiography" for use in teacher education

\footnotetext{
${ }^{16}$ Skinner "Settler-Colonial Art History," 141-66.
} 
classes, in order to encourage teacher candidates to understand themselves as located in a series of colonial relationships. She notes how in discourses of diaspora, the space from which people have come is most represented in the narrative, rather than the place to which they have arrived. This trend, she cautions, risks reproducing the myth of terra nullius - a central trope used to justify imperial expansion and the hostile takeover of Indigenous lands. She positions the decolonizing autobiography as a way of accomplishing what James Clifford offers as a goal for the sharing of personal stories: "to point beyond the individual into ongoing webs of relationships. ${ }^{117}$ Haig-Brown asks, "What does it mean to take seriously not only the land from which one comes, but the land and original people of the place where one arrives?"18

To answer these questions, she proposes that her students tell their own autobiographical story by addressing the land on which they find themselves, and then to engaging in an archeology of all the peoples who have passed through and/or continue to share that space. She also invites students to reflect upon their relationship to the category "Indigenous," and/or to Indigenous communities. This model invites research practices to be grounded within the acknowledgment that land is a foundational part of the story of colonization. By centering stories about land, Haig-Brown's decolonizing autobiography demonstrates how land can be used as a category of analysis in anti-colonial research and practice. This compels the researcher or author to establish their life story as tied to colonial processes and begin to articulate their sense of self in relation to it. When developing a decolonizing autobiography, for instance, themes of land ownership, immigration patterns, racialized segregation (formal or informal), and indigeneity become

\footnotetext{
${ }^{17}$ James Clifford, quoted in Celia Haig-Brown, "Decolonizing Diaspora: Whose Traditional Land Are We On?" Cultural and Pedagogical Inquiry 1, no. 2 (2009): 13.

${ }^{18}$ Haig-Brown, "Decolonizing Diaspora," 16.
} 
deliberately anchored to the articulation of a lived experience, placing colonial relationships at the centre of the narrative. These themes have structured the lives of all subjects living in a place like Canada, and this model invites everyone to participate in using it.

Haig-Brown's model offers clear criteria for how to approach subject matter from an anti-colonial perspective, and this clarity can be useful to scholars working in the humanities. The implications of Haig-Brown's argument are that anti-colonial perspectives must acknowledge land as a category of analysis, and use the history and status of land as a lens through which subject matter is studied and analyzed.

In order to take up Skinner's invitation to recognize that all art and artists in Canada are linked to settler colonialism, as well as Haig-Brown's invitation to use land as a category of analysis, I began my research by looking into the land records related to Wychwood Park. My intention was to understand the political economy of the Park as it related to the development of settler society.

\section{Pursuing Anti-Colonial Research}

The method used to research Wychwood Park's relationship to settler colonialism was a combination of critical discourse analysis and archival research. In the 1980s and 1990s, two different residents of Wychwood Park created an archive of materials related to Wychwood Park's history. Albert Fulton and Keith Miller each researched the history and development of Wychwood Park, and both donated their private collections to the City of Toronto Archives, where they have been consolidated as the Wychwood Park fonds. Importantly, Fulton's and Miller's archives were as concerned with the history of 
Wychwood Park as they were with documenting contemporaneous life in the Park, and the ephemera in their collections suggests they understood themselves to be carrying on a tradition of civic engagement and a celebration of the arts in Toronto.

Miller and Fulton each had copies of the original plan of subdivision for Wychwood Park, Plan 854, dating to 1888, as well as the updated plan, 1092, from 1891. Included in the Wychwood Papers are copies of adjacent plans, such as Plan 332 and Plan 118. These maps offer a glimpse into the stage of residential development that was taking place when the Wychwood Trust was set up. After speaking with archivists at the City of Toronto Archives, I was advised to visit the Land Records Office in order to access information about the date of alienation for the tract of land later included as part of Plan 854.

The Land Records Office is housed on the seventh floor of an office tower at the corner of Bay and Dundas Streets, a busy intersection in downtown Toronto that also houses the Greyhound Bus Terminal. The Land Records Office, while accessible to the public, is not designed for the purposes of research. There were no research guides or staff on hand to assist members of the public in their searches. In order to do a search of a particular property, researchers must first do a computer search, pay with their credit card to access a code, at which point they can then hand their search to the clerk and receive a printed list of recent homeowners for a specific property listing. Given that I was looking for historical files related to an entire community of fifty-eight homes, I sought assistance from land records staff. I had to speak to five people before someone could help me. When I explained I was looking for access to land records that would establish the history of subdivision from the moment of colonial surveyance, I encountered the hostile 
dialogue I cited in my prologue. It was clear I was going to need to search elsewhere for this information. Perhaps naively, at the time I was astounded that the Ontario Land Records Office staff would raise their voice at me for asking about the colonial history of land exchange.

I then abandoned the Land Records Office as a source of information, and after further consultation with City Archives staff, visited the Archives of Ontario, located on the campus of York University. When I explained that I wanted to trace the history of all former owners of the parcel of land that includes Wychwood Park, dating back to its categorization as Crown Land, I was told to abandon my search. "Are you sure you want to do that, honey?" I was asked, "The land records for Toronto are an absolute mess."

There were multiple reasons for this attitude. One was that the way land is categorized changed during the period of my search. For instance, the Toronto region was called Toronto until British officials established Fort York in 1793. The adjacent townsite was referred to as York, in the township of York. In 1834, York was incorporated as the City of Toronto. However, Wychwood Park was outside of city limits until 1909. Shifting place names, and an informal system of land distribution that then became formalized in inconsistent ways, meant creative methods of searching needed to be used in order to establish the area that records have on file. However, the repeated encouragements to abandon my search revealed an institutional attitude that saw land records so old as either irrelevant or too difficult to be worth pursuing.

While land records were not organized consistently according to place names or land use systems, one of the most reliable forms of land records searching was by using patent maps. Patent maps are maps of an area that show the lot boundaries that were 
surveyed for the purposes of distributing appropriated ("Crown") land to settlers for private use. Figure 2.1 shows a patent map for the township of York that became modernday Toronto.

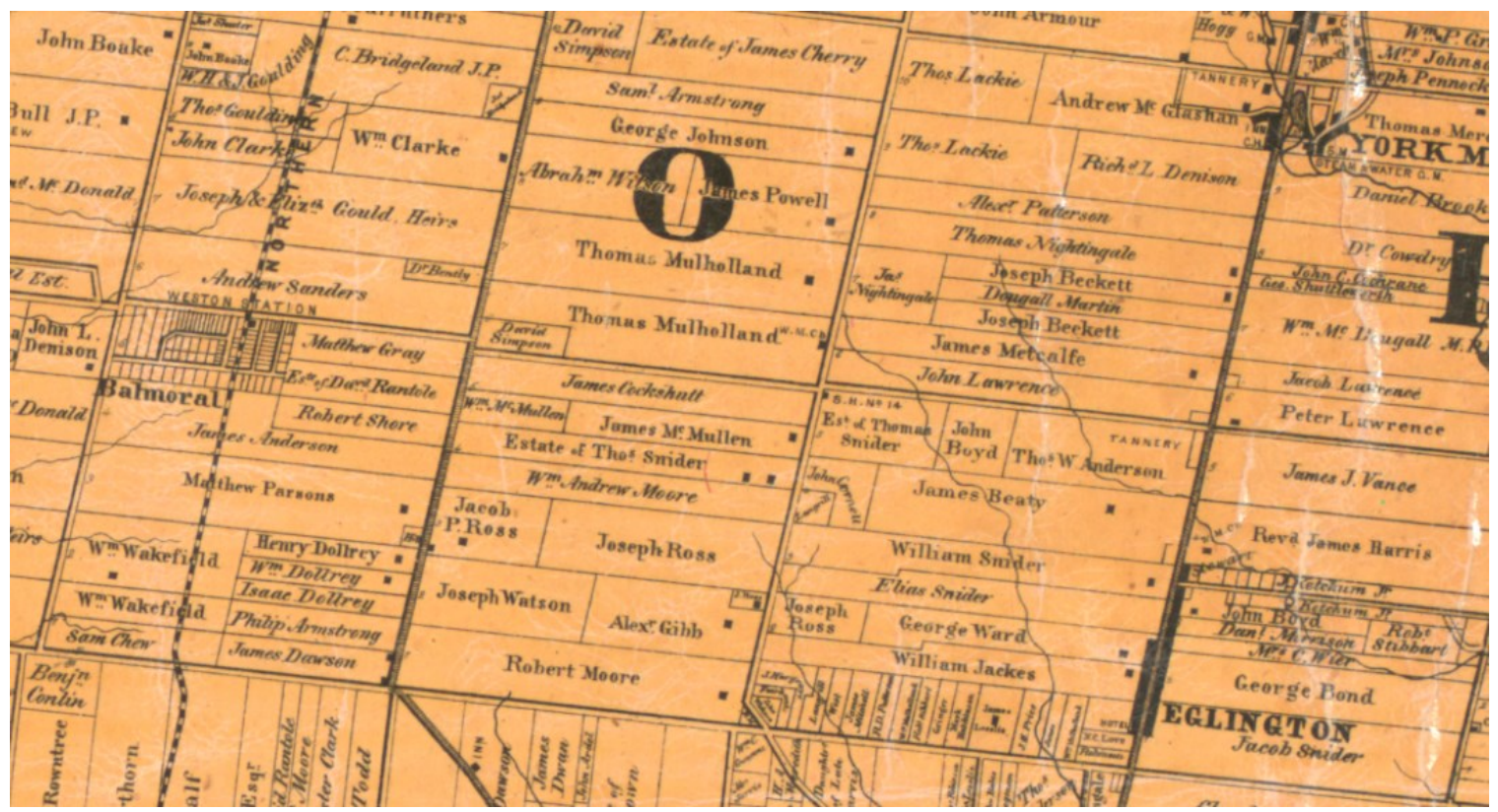

Figure 2.1 Patent Map for the Township of York (detail). Toronto Public Library. https://maps.library.utoronto.ca/hgis/countymaps/york/0010.jpg

When a settler wanted to acquire land in Upper Canada (now Ontario) under British colonial occupation, they were required to petition the Crown asking for land. Once the petition was approved, they would receive a land grant. Upon their fulfilling certain settlement duties (taking up residence on the land, and often "improving" the land by cultivating crops or building a fence or road), the Crown would then issue a patent, demonstrating that the land was now privately owned by the grant-holder.

Patent maps recode territory as patrilineal property. Patent maps demarcate territory according to surveyor's lines and patrilineal last names. Whereas the patent map is a reference for the first colonial patent holder, all subsequent records of land exchange (as well as market value) are organized in the archives by the last name of the last owner. 
Therefore, in order to research a comprehensive history of land occupation, I needed to approach the archives as though I were a genealogical researcher, researching a particular settler. The land records at the Archives of Ontario enabled me to access, based on last name, the names of the two British soldiers who were granted neighbouring lots that include the land that is now called Wychwood Park. Once I had located the patent holders' names, the Archives of Ontario staff concluded that I needed to return to the land records office in order to find further information on land exchange.

Returning to the Land Records Office, I navigated the informal access barriers by highlighting my status as a doctoral researcher. Once I identified that records of subdivision and sale were essential to my doctoral dissertation, I was granted access to staff not visible to the public, including one who was instructed to assist me by his supervisor, who claimed, "You need to help Emma find what she needs. She is studying to be a doctor, and she will bless you." After weeks of fruitless searching, my familiar presence in the office caught the attention of a senior staff member leaving to smoke a cigarette. He asked what I was working on, and commented, "Oh you poor thing! Have you been looking for nineteenth-century records? No one here knows where they are. Here, come to this bookcase." After about thirty minutes of searching, he found the ledger with handwritten land records on it for the two lots in the land concession that I required. These research methods were entirely informal, and required triggering a series of social relations in order to take place.

More importantly, however, the ledger I found was the only record of early settler property transactions for Wychwood Park that I could find in the three main archives in Toronto: The City of Toronto Archives, the Archives of Ontario, and the Land Records 
Office. The ledger containing the only information that would make it possible to calculate the property values in a historical sense was sitting on a bookshelf with no catalogue number on it, no guarantee it would be on the same shelf the next day, and no regulations to wear gloves to ensure its legibility wouldn't be compromised or destroyed. In short, these documents were no longer considered to be as relevant as the digitized records of contemporary property exchange in Toronto. However, there is no way to fully calculate the accumulation of settler wealth over the past two hundred years without these records. Further, the British claim to territory in the Toronto area has been contested by Mississauga leaders since the early nineteenth century - a dispute formally resolved in a land claim settlement in 2010. The attitudes of archival staff and the (dis)organization of land records, as well as the normalization of settler occupation through search aids such as patent maps, demonstrate systemic efforts to undermine the legitimacy of Indigenous land claim in Toronto. To paraphrase Blomley, the lack of information about land in Toronto was not an outcome of poor record-keeping, but a realization of settler colonial land policy.

What became clear as I pursued my research was that anti-colonial research requires not just a method of inquiry but an awareness of how the research process will be systematically impeded by the ongoing settler colonial project.

\section{Affective Construction of the Archive}

Researching the political economy of settler colonial land distribution demanded that I engage in genealogical research methods, because land records are organized according to settler last name. Land records are genealogical records in Canada's settler 
colonial context - reinforcing colonialism as embedded within settler kinship systems and social organization. Through this process, the archive became an affective environment, whereby I became over-familiar with particular biographical details rather than others. The research process invited me to imagine myself as directly connected to the life of the settler I was researching. This implicitly produces the land record as an opportunity to participate in the cult of the pioneer, exalting the hardships and the identification with the land that the imagined pioneer experienced.

The most formalized source of information to access land records was from genealogical source guides. Genealogy guides were able to explain why particular place names would have changed and/or what kind of incomplete records reflected different social contexts. While archival staff often discouraged me from pursuing my research into the history of property exchange in Wychwood Park, those who offered consistent support were genealogical researchers, working away at neighbouring desks. However, to participate in their epistemological system I needed to treat my research subjects as ancestors.

One of the contributions of queer theorists to the study of history has been the lens of affect as a category of analysis. Ann Cvetkovich, for instance, in her examination of lesbian culture through the lens of trauma, understands affect as "uncontainable" in traditional archives, and points to lesbian texts as "an archive of feelings" that can more accurately capture the impacts of trauma in a culture. While Cvetkovich is concerned with making "room" for cultural texts to be considered part of an affective archive, she is nonetheless arguing for the cultural import of archives more generally. She writes, "My approach to genre has been inclusive because the resulting range of texts and artifacts 
enables attention to how publics are formed in and through cultural archives. ${ }^{, 19}$ I think there is room here to apply her ideas onto conventional archival spaces, as Cvetkovich's ideas invite consideration of the possibility that conventional archival spaces are indeed cultural, and that they form cultural publics.

In my experience as a researcher in the archival spaces that house land records, I encountered multiple affective dynamics that served to create a cultural public. Affective discourses of pride, excited curiosity, and mastery over transactional trivia circulated almost constantly at the Archives of Ontario, between researchers, among staff, and in the pages of research guides. These affective acts contributed to a momentum of disavowal with regards to the political context and implication of the records we were reviewing. For example, the pride we were encouraged to feel at finding a settler's land petition necessarily implicated us in the denial that we were reading a series of transactions that were facilitating the economic exclusion of Indigenous peoples from the new, capitalized settler economy.

Another contribution of queer theorists to the field of critical historiography is the idea of "queer time." Elizabeth Freeman explores the idea of "queer temporality," a concept that explores how bodies are culturally "produced" according to normative constructions of time. Freeman's analysis has the potential to reach beyond the context of queer politics and consider a deeper understanding of how groups of people understand themselves as connected to narratives of time. In a chronobiological society, she contends, "the state and other institutions, including representational apparatuses, link

\footnotetext{
${ }^{19}$ Ann Cvetkovich, An Archive of Feelings: Trauma, Sexuality, and Lesbian Public Cultures (Durham, NC: Duke University Press, 2003), 9. Emphasis mine.
} 
properly temporalized bodies to narratives of movement and change. ${ }^{, 20}$ She approaches state-regulated records such as birth, death, and marriage certificates, records of property exchange, driving licences, and military service records to be "teleological schemes of events or strategies for living" that allow personal histories to become "legible only within a state-sponsored timeline ... In the eyes of the state, this sequence of socioeconomically 'productive' moments is what it means to have a life at all.,"21

These ideas inform my reading of the land records for the City of Toronto. Equipped with the understanding that I was reading only a partial archive, I was interested in what information was omitted. Importantly, the missing information was not simply not there; it was coded as irrelevant. In this way, settler lives become interpellated by the state archive as individual, as productive, as capitalized, as masculine, while feminized and Indigenous lives are excluded as part of a seemingly irrelevant collective. Importantly, the land records attach specific last names to specific plots of land - literally mapping settler lineage across geopolitical spaces, transforming them into productive spaces of industrious and capitalized activity. As Freeman writes: "The logic of time-asproductive thereby becomes one of serial cause-and-effect: the past seems useless unless it predicts and becomes material for a future. These teleologies of living, in turn, structure the logic of a 'people's' inheritance: rather than just the transfer of private property along heteroreproductive lines, inheritance becomes the familial and collective legacy from which a group will draw a properly political future - be it national, ethnic, or something else. ${ }^{22}$

\footnotetext{
${ }^{20}$ Elizabeth Freeman, Time Binds: Queer Temporalities, Queer Histories (Durham, NC: Duke University Press, 2010), 4.

${ }^{21}$ Freeman, Time Binds, 4.

${ }^{22}$ Freeman, Time Binds, 5.
} 
The legacy of settler occupation is central to the political future that is celebrated within the archives, and the practice of searching through them. The most comprehensive guides, for instance, are those published by genealogical societies. Within the guides, researchers are constantly encouraged to pursue different methods of searching for information related to "your ancestor," and the history of land acquisition is characterized by policy changes that periodize time according to when land was "freely available." 23 These characterizations establish the research environment as one that naturalizes the colonial occupation of Toronto, and frames historical research as a source of personal identification in the colonial story. My experience of collecting research data naturalized a system of land acquisition and distribution that was inherently gendered and racialized: Indigenous land was appropriated and white male settlers were granted land as named individuals. The research environment was designed institutionally and affectively to refute the political context in which land appropriation and colonial occupation is naturalized.

In order to interpret the data I had collected in the archives, I relied on a theoretical and conceptual framework drawn from Critical Landscape Studies and Critical Whiteness Studies. This conceptual framework, as I explain below, equipped me with the tools to approach land records and neighbourhood archives as constitutive of a broader system of social, economic, political, and cultural power relations.

\footnotetext{
${ }^{23}$ Brenda Merriman, Genealogy in Ontario: Searching the Records (Toronto: Ontario Genealogical Society, 2013), 132-3.
} 


\section{Conceptual Framework: Racialized Landscapes}

\section{Critical Landscape Studies}

When I argue that Wychwood Park is a white settler colonial landscape, I am invoking the insistence put forward by Critical Landscape Studies that social power can be read within physical geographies. In W.J.T. Mitchell's words, a critical study of landscape requires that scholars "trace the process by which landscape effaces its own readability and naturalizes itself." 24 In this dissertation, I argue that the Park is a white settler colonial landscape - an argument that necessarily reads the space as racialized. By studying Wychwood Park's landscape as racialized, I align myself with Anne Bonds and Joshua Inwood's contention that "landscapes do not merely reflect racial patterns; they are a fundamental component of processes of racialization. ${ }^{25}$ This dissertation argues that Wychwood Park's bucolic, anglicized beauty is not only a reflection of British design trends but also a constitutive part of the racialization of Toronto as a white settler colonial city.

Critical Landscape Studies scholars engage with the multiple overlapping definitions of "landscape." Landscape refers to a territorial area (" $a$ landscape"), a way of engaging physically with the land ("to landscape"), as well as a genre of art ("to paint a landscape"). John Wylie illustrates how dictionaries define landscape as "that portion of land or scenery which the eye can view at once, ${ }^{, 26}$ which signals how the viewer and their gaze are necessarily implicated in the idea of landscape as differentiated from land itself.

\footnotetext{
${ }^{24}$ W.J.T. Mitchell, ed., Landscape and Power (Chicago: University of Chicago Press, 1994), 2.

${ }^{25}$ Anne Bonds and Joshua Inwood, "Beyond White Privilege: Geographies of White Supremacy and Settler Colonialism," Progress in Human Geography 40, no. 6 (2016): 717.

${ }^{26}$ John Wylie, Landscape (New York: Routledge, 2007), 6. Emphasis in original.
} 
Critical Landscape Studies, then, considers ways that we look at land, and how our gaze is reflected in the ideas attached to land. As Wylie argues, "Landscape is not only something we see, it is also a way of seeing things, a particular way of looking at and picturing the world around us ... studying landscape involves thinking about how our gaze ... is always already laden with particular cultural values, attitudes, ideologies and expectations. ${ }^{27}$ In this dissertation, I approach settler colonialism as the system that transforms territory from land into landscape through the adoption of a settler colonial gaze. Settler colonial landscapes can simply be thought of as land in a settler colony, but using a critical landscape lens, settler colonial landscapes are also the way land gets revisioned through the cultural attitudes cultivated in and through settler colonial ways of knowing.

Wylie's definition offers a premise for my study of Wychwood Park's physical landscaping. The Wychwood Park landscape is something beautiful to look at, certainly, but its beauty is situated within a set of cultural values that legitimize British aesthetics, within ideologies built on the logic of Indigenous elimination, and within expectations that Toronto land belongs to the settlers who purchased it or were granted title to it. It is perhaps because land is so embedded within ideological systems that Denis Cosgrove describes landscape as a form of "visual ideology." ${ }^{28}$ Importantly, Wychwood Park's heritage designation was established on the basis that its landscape design was worth preserving as a cultural artifact in and of itself. Critical Landscape Studies asks cultural questions about the natural environment, or as W.J.T. Mitchell argues, it changes the definition of landscape "from a noun into a verb." By doing so, the field reveals landscape

\footnotetext{
${ }^{27}$ Wylie, Landscape, 7. Emphasis in original.

${ }^{28}$ Denis Cosgrove, "Prospect, Perspective, and the Evolution of the Landscape Idea," Transactions of the Institute of British Geographers 10, no. 1 (1985): 47, quoted in Wylie, Landscape, 63.
} 
as "a process by which social and subjective identities are formed." ${ }^{29}$ Similarly, I approach the task of landscaping, the art of designing Wychwood Park as a place the William Morris Society would want to tour, as an example of settler colonial labour. The place-making power of Wychwood Park's gardens produces in Canadian territory a distinctly British place, as well as attendant local cultural traditions and lore.

Richard Schein offers a methodological framework for situating landscape within its ideological context as the study of cultural landscapes. He argues that cultural landscape is "an exercise in interrogating the role of landscape in social and cultural reproduction." ${ }^{30}$ Schein argues that cultural landscapes are both a "material presence and a conceptual framing." 31 In other words, the physical landscape of a place, as well as the ideas that give the site place-making power, are equally embedded as ideological forces in any given society. Schein's argument situates landscapes as active agents within an ideological process. He asserts that landscapes are "not just material ephemera of cultural practice; they are the very reinforcement of that practice." ${ }^{, 32}$ In this dissertation, I rely on Schein's arguments as I consider the English gardens in Wychwood Park to be not only a metaphor for the British colonial occupation of Toronto, but also an example of the how such an occupation is sustained. The cultural landscape framework offers a model for understanding the ideological function of the aesthetic landscaping of the Park, and also the role the Park plays in naturalizing racialized ideas about belonging and nature in the Canadian context.

\footnotetext{
${ }^{29}$ Mitchell, Landscape and Power, 1.

${ }^{30}$ Richard Schein, "The Place of Landscape: A Conceptual Framework for Interpreting an American Scene," Annals of the Association of American Geographers 87, no. 4 (1997): 660.

${ }^{31}$ Schein, "Place of Landscape," 662.

${ }^{32}$ Richard Schein, “A Methodological Framework for Interpreting Ordinary Landscapes: Lexington, Kentucky’s Courthouse Square,” Geographical Review 99, no. 3 (2009): 396.
} 
As landscapers, Wychwood Park residents were reshaping the environment where they lived into an environment reminiscent of idealized English history. Further, their pristine garden setting represented a contrast to the polluted downtown core where racialized immigrants lived. This spatial contrast was also a racialized contrast, producing an association of whiteness with anglicized gardens and non-whiteness with inner-city slums. As Andrew Baldwin has argued, "nature was an important resource in the articulation of white identity in the early twentieth century." ${ }^{33}$ Baldwin is speaking specifically about the idea of nature as it relates to mythical depictions of Canada as a great uninhabited wilderness that could be claimed by industrious pioneers intent on building a nation.

The symbolic pioneer is a long-established trope in Canadian nationalist mythologies. Pioneers have been used to allegorically characterize Canadian land as uninhabited, and to characterize industrious white male bodies as belonging to Canadian territory. Wychwood Park, by contrast, is not an example of an untouched wilderness, but rather a cultivated wilderness. The space of Wychwood Park is rendered useful through the labour of a refined artist rather than a rugged pioneer. In this way, Wychwood Park's white settler colonial landscape is an example of how whiteness was articulated in industrialized urban contexts at the turn of the twentieth century. This orientation to the whiteness of Wychwood Park relies on an understanding of whiteness as a dynamic social position that has many iterations. As Schein has argued, "the discourse of racialized social relations works through landscapes. ${ }^{\text {34 }}$ Schein locates landscapes as examples of

\footnotetext{
${ }^{33}$ Andrew Baldwin, "The White Geography of Lauren Stewart Harris: Whiteness and the Performative Coupling of Wilderness and Multiculturalism in Canada," Environment and Planning 41 (2009): 531. 34 Schein, "Methodological Framework," 396.
} 
"discourse materialized." ${ }^{35}$ Whiteness, as the normative form of racialization in Canada, is produced in and through spatializing practices. In the next section, I summarize key concepts from the field of Critical Whiteness Studies that inform my argument.

\section{Critical Whiteness Studies}

Studies of whiteness, white identity formation, and white privilege have organized themselves as the field of Critical Whiteness Studies since the $1990 \mathrm{~s} .{ }^{36}$ As a field, Critical Whiteness Studies is informed by post-colonial scholarship that theorized racialized social hierarchies $;{ }^{37}$ feminist scholarship that theorized privilege, oppression, and subjectivity ${ }^{38}$ and Marxist historical studies that documented relationships between race and class in late capitalist social formations. ${ }^{39}$ This dissertation is informed by studies of whiteness that map how whiteness produces and is produced by space in a settler colony. Before I illustrate my engagement with the concepts that facilitate this argument, I will briefly summarize definitions of whiteness as an introduction to my more focused discussion of whiteness and racialized space.

The study of whiteness may be more aptly described as the study of whitenesses, a way of understanding white supremacy as operating in multiple and sometimes

\footnotetext{
${ }^{35}$ Schein, "Place of Landscape," 666.

${ }^{36}$ The introduction to Mike Hill, ed., Whiteness: A Critical Reader (New York: NYU Press, 1997) offers a solid summary of the field's beginning. Key texts include Richard Dyer, White: Essays on Race and Culture (New York: Routledge, 1997); Ruth Frankenberg, White Women, Race Matters: The Social Construction of Whiteness (Minneapolis: University of Minnesota Press, 1993); Vron Ware, Beyond the Pale: White Women, Racism, and History (London: Verso, 1992); David Roediger, The Wages of Whiteness: Race and the Making of the American Working Class (London: Verso 1999); Theodore Allen, The Invention of the White Race (London: Verso, 1994).

${ }^{37}$ Frantz Fanon, Black Skin White Masks, trans. Richard Philcox (New York: Grove Press, 2008).

${ }^{38}$ Patricia Hill Collins, Black Feminist Thought: Knowledge, Consciousness, and the Politics of Empowerment (New York: Routledge, 2000); bell hooks, Feminist Theory from Margin to Center (Boston: South End Press, 1984).

${ }^{39}$ Roediger, Wages of Whiteness; Allen, Invention of the White Race.
} 
contradictory ways. Studying whiteness takes place in the context of studying racism. As Baldwin et al. have succinctly argued, one way of defining whiteness is as the "norm against which racism occurs. ${ }^{40}$ If whiteness is constructed as normal by racism, then the study of whitenesses is required in the context of racisms. As David Theo Goldberg has argued, "there may be different racisms in the same place at different times; or different racisms in various different places at the same time; or again different racist expressions different in the conditions of their expression, their forms of expression, the object of their expressions, and their effects - among different people at the same space-time conjuncture."

Building upon Goldberg's characterization of racism, I understand whiteness to be socially constructed ${ }^{42}$ and historically contingent. ${ }^{43}$ By socially constructed, I am referring to whiteness as shaped by the relations of power that sustain white supremacy. By historically contingent, I am referring to the shifting definitions of whiteness over time, as well as the varied expressions of power related to it. This dissertation approaches whiteness as a shifting social identity and ideological system that naturalizes white supremacy and settler colonialism in Canada.

As a signifier of unmarked identities, whiteness is often described as invisible. ${ }^{44}$ However, as Sara Ahmad has argued, "whiteness is only invisible to those who inhabit it." 45 In order to read/study whiteness, critical scholars have argued that whiteness can be

${ }^{40}$ Andrew Baldwin, Laura Cameron, and Audrey Kobayashi, Rethinking the Great White North: Race, Nature, and the Historical Geographies of Whiteness in Canada (Vancouver: UBC Press, 2011), 5.

${ }^{41}$ David Theo Goldberg, Racist Culture: Philosophy and the Politics of Meaning (Oxford: Blackwell, 1993), 95.

${ }^{42}$ Frankenberg, White Women, Race Matters.

${ }^{43}$ Noel Ignatiev and John Garvey, eds., Race Traitor (New York: Routledge, 1996).

${ }^{44}$ Richard Dyer, White.

${ }^{45}$ Sara Ahmed, "Declarations of Whiteness: The Non-Performativity of Anti-Racism," borderlands ejournal 3, no. 2 (2004). 
located "as much through presence as absence, as much through what is said as through what remains unsaid and silenced. ${ }^{\text {"46 }}$ Part of white supremacy's function is to make racism look as though it only involves people of colour, enabling white bodies to go undescribed, unmarked, and unsituated as racialized actors. In research, white identities are assumed when race goes unmentioned, a pattern that critical scholars have pointed to when describing whiteness as performing a "universalizing" ${ }^{, 47}$ function that reinforces a "mythical norm" in the study of power and oppression. ${ }^{48}$ As Audrey Kobayashi and Linda Peake have argued, "Whiteness is indicated less by its explicit racism than by the fact that it ignores, or even denies, racist indications. It occupies central ground by deracializing and normalizing common events and beliefs, giving them legitimacy as part of amoral system depicted as natural and universal. In such a system, whiteness is embodied and becomes desire in the shape of the normative human body, for which 'race' provides an unspecified template." 49

This dissertation's re-reading of Wychwood Park as a white settler colonial landscape names whiteness as one of the ideological forces that has contributed to the characterization of the Park as a de-racialized landscape both in academic and popular representations of Toronto. In order to counter the de-racialized way that Wychwood Park has been studied, I assert that the Park reinforces ideas and sensibilities that have been central to white identity formation in Canada.

${ }^{46}$ Baldwin, Cameron, and Koyabashi, Rethinking, 3.

${ }^{47}$ Aileen Moreton Robinson, Talkin' Up to the White Woman: Aboriginal Women and Feminism (St. Lucia: University of Queensland Press, 2002), 32.

${ }^{48}$ Audre Lorde, Sister Outsider: Essays and Speeches (Freedom, CA: Crossing Press, 1984), 116.

${ }^{49}$ Audrey Kobayashi and Linda Peake, "Racism Out of Place: Thoughts on Whiteness and an Antiracist Geography in the New Millennium," Annals of the Association of American Geographers 90, no. 2 (2000): 394. Emphasis mine. 
Daniel Coleman argues that whiteness is "only partially about skin." ${ }^{, 50}$ In his study of what he calls "white civility," Coleman argues that "race is not just bodies, but also conduct." ${ }^{51}$ He argues that Canadian cultural whiteness is built upon the idea of white civility, which he describes as "cultivated, polite behaviour ... fundamental to the production and education of good citizenship." ${ }^{, 52}$ White civility is associated with English cultural codes of gentlemanly behaviour and myths that distinguish Canadian colonial history as more peaceful than American history in part because of Canada's Britishness. As a cultural value, white civility informs stereotypes such as the polite Canadian with an endless compulsion to apologize, but also serves to mask the violent context through which the Canadian state, and its attendant nationalist culture, functions. In other words, white civility is a practice embedded within the settler colonial discourse of disavowal. White civility is also reinforced through the discourse of multiculturalism - a policy, practice, and national narrative that has been criticized for positioning normative white de-ethnicized Canadian culture in opposition to the ethnicized, racialized cultures on display as multicultural. ${ }^{53}$

Cultivated, polite behaviour as a signifier of whiteness in Canada signals both cultural Englishness and upper middle class behaviour. The twinning of Anglo cultural identity and class aspiration have been central to the social construction of whiteness on the North American continent for the past two hundred years. As historical studies of

${ }^{50}$ Andrew Baldwin, "Whiteness and Futurity: Towards a Research Agenda," Progress in Human Geography 36 (2012): 173.

${ }^{51}$ Daniel Coleman, White Civility: The Literary Project of English Canada (Toronto: University of Toronto Press, 2006), 12.

${ }^{52}$ Coleman, White Civility, 10.

${ }^{53}$ Himani Bannerji, The Dark Side of the Nation: Essays on Multiculturalism, Nationalism, and Gender (Toronto: Canadian Scholars Press, 2000); Sunera Thobani, Exalted Subjects: Studies in the Making of Race and Nation in Canada (Toronto: University of Toronto Press, 2007); Enakshi Dua and Angela Robertson, eds., Scratching the Surface: Canadian Anti-Racist Feminist Thought (Toronto: Canadian Scholars Press, 1999). 
whiteness have shown, many ethnic groups currently considered "white" in North America were once racialized as ethnic "others" whose allegiance to the nationalist projects of both Canada and the United States were mythologized as precarious to justify instances of political exclusion and state violence. ${ }^{54}$ As scholars have shown, whiteness became an ideological tool in the late nineteenth and early twentieth centuries to quell working class radicalism by promising white workers the illusion of economic mobility based on the fiction of race. ${ }^{55}$ Working class racism ensured the working classes remained divided, and whiteness became associated with the politics of class distinction that expresses itself as respectability.

Politeness as a racialized code is contrasted with racist myths that characterize nonwhite bodies and cultural practices as rude, loud, crass, and unkempt. These stereotypes function to normalize white wealth while justifying racialized poverty, a logic that disavows any structural analysis of inequality. The association of being white with being polite and respectable informs Bobby Noble's description of whiteness as a "classbased race: the higher up you go, the whiter you get." ${ }^{, 56}$ Within the literature on critical whiteness, whiteness has been defined as culturally refined, ethnically British, and authentically upper/middle class. This dissertation reads Wychwood Park as a white landscape in part because the neighbourhood is often characterized in similar terms.

Scholars have situated the construction of Canadian whiteness as a racial formation "forged through the colonial encounter." ${ }^{, 57}$ Specifically, scholars who study

\footnotetext{
${ }^{54}$ See in particular Roediger, Wages of Whiteness; Allen, Invention of the White Race; Ignatiev and Garvey, Race Traitor.

${ }_{55}^{55}$ David Roediger's Wages of Whiteness is a particularly useful book for this point.

${ }^{56}$ Jean Bobby Noble, Sons of the Movement: FtMs Risking Incoherence on a Post-Queer Cultural Landscape (Toronto: Canadian Scholars' Press, 2006), 87.

${ }^{57}$ Sheelah McLean, "The Whiteness of Green: Racialization and Environmental Education," The Canadian Geographer 57, no. 3 (2013): 357.
} 
Canadian whiteness have theorized how it is expressed in spatial ideas about the Canadian nation. For instance, the colonial story of Canada celebrates the role of the hard-working pioneer, whose legitimacy in Canada is secured through a relationship to the land. The concept of wilderness, and in particular a wilderness that gets transformed into farmland, is a key metaphor in the construction of Canadian whiteness. As Andrew Baldwin argues, "the idea of wilderness furnishes white Canadians with a discourse that legitimizes their national belonging as pioneering." ${ }^{, 58}$ To that end, Baldwin argues that "hard, purposeful labour" produces white space, ${ }^{59}$ while white bodies "become white" in nature. ${ }^{60}$

Unlike the hard, purposeful labour of the pioneer, Wychwood Park residents did not produce white space by transforming the wilderness into farmland. Wychwood Park residents instead produced white space by performing the civilizing work of gardening. Gardening accomplishes a different relationship to space than farming. Gardening curates the landscape according to the aesthetic preferences of the gardener, rather than the economic needs of the farmer. Gardening's place-making power is in the way it designates space as a site of leisure rather than labour.

The garden suburb of Wychwood Park distinguished itself from the symbolic pioneer farms associated with earlier waves of settlement by representing an era of settler cultural refinement. Whereas earlier eras of settler life in Canada were encoded in narratives of self-sacrificing pioneers, the early twentieth century was a time in which nation-builders articulated world-class ambitions for Canada. Canadian art was exhibited

\footnotetext{
${ }^{58}$ Baldwin, "White Geography," 542.

${ }^{59}$ McLean, "Whiteness of Green," 359. McLean references Andrew Baldwin, "Wilderness and Tolerance in Flora MacDonald Denison: Towards a Biopolitics of Whiteness," Social and Cultural Geography 11 (2010): 892.

${ }^{60}$ McLean, "Whiteness of Green," 360. Mclean references Andrew Baldwin, "Ethnoscaping Canada's Boreal Forest: Liberal Whiteness and its Disaffiliation from Colonial Space," The Canadian Geographer 53 (2009): 431.
} 
in international exhibitions, railway tycoons hoped to establish cities that would outpace Chicago on the Canadian prairies, and civic leaders in Toronto pushed for the creation of cultural institutions that would rival those found in Paris or London. These ambitions for Canada reflect an era of national development, whereby the settler colonial project had become so ubiquitous that the idea of Canada began to appear, to paraphrase Walcott, as unrelated to colonialism. In other words, at the turn of the twentieth century, as Wychwood artists were beginning to promote a departure from purely British styles towards a more clearly delineated Canadian aesthetic, settler colonialism was beginning to be storied as a relic of Canada's past.

In the following chapter, I explore the occupation and settlement of Ontario in detail, illustrating how Battell Lowman and Barker's goal of settler colonialism, "Indigenous Elimination," was achieved in part through the transformation of territory into private property. 


\section{Chapter Three \\ Indigenous Elimination: Historical Context for the Development of Wychwood Park: Private Property, Settler Space, and the History of Nineteenth-Century Toronto}

When Settler Canadians buy a house in the suburbs, we are doing more than engaging in a private financial transaction: we are purchasing the idea of that land as ours ... Our purchase is a benefit of our placement on the inside of the structures of settler colonialism, and also a denial of Indigenous claims to those same lands.

Emma Battell Lowman and Adam J. Barker ${ }^{1}$

A year after [Toronto] was founded, when only twelve houses had been built, the document that formed the legal basis for the settlement was known to be invalid and the exact limits of the Purchase were unknown.

Victoria J. Freeman ${ }^{2}$

To understand the development of American (and Canadian) society, we need to examine their foundation: the contested process of acquiring Indian land to make private property.

Alan Taylor ${ }^{3}$

As Patrick Wolfe has argued, settler colonies are premised upon a "logic of elimination" regarding Indigenous authority, land use, land claim, and social life. ${ }^{4}$ This chapter documents how the elimination of Indigenous land use and land claim was facilitated through the settler colonial land economy - and most principally the tool of private property. As Wolfe and others have argued, the logic of elimination is an ongoing

\footnotetext{
${ }^{1}$ Emma Battell Lowman and Adam J. Barker, Settler Identity and Colonialism in 21st Century Canada (Halifax: Fernwood, 2015), 32.

${ }^{2}$ Victoria J. Freeman, “'Toronto Has No History!': Indigeneity, Settler Colonialism, and Historical Memory in Canada's Largest City” (PhD diss., University of Toronto, 2010), 64.

${ }^{3}$ Alan Taylor, The Divided Ground: Indians, Settlers, and the Northern Borderland of the American Revolution (New York: Vintage Books, 2006), 9.

${ }^{4}$ Patrick Wolfe, Settler Colonialism and the Transformation of Anthropology (London: Bloomsbury, 1999).
} 
process that continues to inform the realities of settler colonial society. In this chapter, I examine one manifestation of settler colonialism's logic of elimination - the transformation of Indigenous land into private property. This chapter argues that Wychwood Park is a settler colonial site because it is a collection of privately owned homes on land that was commodified through colonial land policies designed to eliminate Indigenous land title.

This chapter offers a descriptive history of the long and complicated process through which British officials pursued settler colonialism in what became Ontario. I deliberately go into detail as a way of countering the research convention of glossing over settler colonial history, summarizing British settlement as though it were always an inevitability in the Toronto region. Further, this chapter's focus on the process by which British officials depressed the value of land in order to facilitate Indigenous poverty and territorial dispossession is an original contribution to the study of the Park and its significance. Wychwood Park's settler colonial context is consistently ignored in all public histories and contemporary descriptions of the Park. Formalized in academic research, local history research, and press profiles of the Park, the public narrative of Wychwood Park contains abundant references to early residents such as Marmaduke Matthews, George Reid, and Eden Smith, whose geographic imaginations are cited as the reason why the Park has been landscaped and designed to the extent that it has. As I mentioned previously, the heritage plaque installed at the Park's northern pedestrian entrance legitimizes Wychwood Park's history as one that began in 1888 with the purchase of land. Land commodification is a central theme that facilitates the widely 
accepted narrative of Wychwood Park's history - a narrative that invisibilizes Indigenous land use, land claim, history, and presence in the Toronto area.

This chapter explores how Indigenous invisibility has been achieved within the Wychwood Park narrative by focusing specifically on the history of territorial control in the Toronto area prior to 1888. By establishing a land economy premised upon Indigenous exclusion, settler colonial governments used private property as a tool for Indigenous territorial dispossession.

Battell Lowman and Barker illustrate how "Indigenous elimination" can refer to genocidal violence, but also denotes the systematic denial or prohibition of Indigenous land claim, land use, and social power. They write, "what the Settler society desires is not necessarily the death of Indigenous people per se ... settler colonialism requires the death of Indigenous peoples as such ... Indigenous relationships to the land cannot be allowed to pre-empt and undermine colonial claims to the land ... Indigenous histories and creation stories cannot be allowed to compete with heroic origin stories of brave pioneers and frontier individualism.." This chapter argues that Wychwood Park's white settler colonial landscape depends upon Indigenous elimination. Specifically, the elimination of Indigenous land use and land claim was made possible by the use of private property as an economic tool of settler colonial capitalist social formation.

Alan Taylor's provocative statement that the expropriation of Indigenous land is a "foundational" element of North American society invites a critical examination of private property. Critical scholars have long recognized private property as a byproduct of capitalist society, but it is not always named as a specifically colonial phenomenon. Following Taylor's assertion, this chapter approaches private property as a colonial

\footnotetext{
${ }^{5}$ Battell Lowman and Barker, Settler Identity, 30.
} 
concept that has shaped land use, historical memory, and cultural place-making in Toronto. This approach understands the history of all residential development in the City of Toronto as necessarily shaped by, and contributing to, "contested process[es] of acquiring Indian land." These processes are not fixed, but ever shifting, being made and re-made through ideological, geographic, and symbolic systems. This chapter provides a historical overview of the urban development of Toronto in order to understand the broader context in which Wychwood Park became established as a subdivision. This chapter outlines how Toronto became a site of British settlement, the circumstances in which it expanded to become a city, and finally, an accounting of how property has been exchanged in the Wychwood Park neighbourhood.

\section{The Toronto Carrying Place as Multinational Homeland}

The area now referred to as the City of Toronto has been a site of sacred ceremony, transnational trade, and efficient travel since time immemorial. Its position on Lake Ontario has been compared to the Mediterranean to highlight the region's diversity and its natural and cultural wealth. ${ }^{6}$ The Toronto area has been home to many different communities, whose shared sense of belonging has been organized ethnically, politically, culturally, linguistically, and economically. While the British negotiated land cessions of the Toronto area from the Mississauga of the Credit River in 1788, many nations claim the Toronto Carrying Place as an ancestral homeland. This section will offer a brief overview of the region and its many names.

\footnotetext{
${ }^{6}$ Rodney Bobiwash, "The History of Native People in the Toronto Area," in The Meeting Place: Aboriginal Life in Toronto, ed. Frances Sanderson and Heather Howard-Bobiwash (Toronto: Native Canadian Centre of Toronto, 1997), 7.
} 
Different versions of the word "Toronto" appear in many different languages to refer to various referents in the northern Great Lakes region. It has appeared in European maps as "Tarento," "Tkaronto," and "Lac Taronto." Alan Rayburn suggests that "Toronto" is the British transliteration of the Mohawk "Tkaronto," which means "where there are trees standing in the water," referring to the fish weirs recorded by Samuel de Champlain in 1615 as standing in The Narrows where Lake Simcoe empties into Lake Couchiching near Orillia. ${ }^{8}$ In 1680, Lake Simcoe appeared on a French map as "Lac Taronto." The Humber River has also appeared on maps as "Rivière Taronto." The French trading fort that sat where the Humber empties into Lake Ontario in the early to mid-eighteenth century was named "Fort Toronto." ${ }^{99}$ Historian Percy Robinson notes that Torontogueronons was a name given to Huron-Wendat people by Lahontan, meaning "people who live at Toronto." Further, Robinson notes "Otoronton," a word meaning "land of plenty," as a way that the Toronto region was remembered by Hurons, Petuns, and Neutrals who were exiled in the mid seventeenth century. ${ }^{10}$ Part of the reason that Toronto has been used to describe so many significant sites is because the Toronto Carrying Place was a longstanding overland portage route used to access Georgian Bay from the southeast. Ron Williamson cautions that the Toronto Carrying Place should be considered in the context of the land crossed by the trail, rather than just the trail itself. ${ }^{11}$ The land contained within the term "Toronto Carrying Place" is the land that links Lake Ontario to Lake Simcoe, but it also invokes a broader sense of place and

\footnotetext{
${ }^{7}$ Alan Rayburn, "The Real Story of How Toronto Got Its Name," Canadian Geographic 114, no. 5 (1994): 68.

${ }^{8}$ Rayburn, "Real Story," 68.

${ }^{9}$ Rayburn, "Real Story," 68.

${ }^{10}$ Percy Robinson, "The Toronto Carrying Place and the Toronto Purchase," Ontario History 34 (1947): 43.

${ }^{11}$ Ron Williamson, "It's Not the Trail: It's the Land it Crosses," Heritage Toronto, http://heritagetoronto.org/its-not-the-trail-its-the-land-it-crosses/. Accessed March 11, 2014 (no longer available).
} 
interconnectedness that links the Toronto region to a broader network of international trade, travel, and alliance.

There are two central linguistic families that figure prominently in the history of the Toronto region: Algonkian (Anishinaabek) and Iroquoian (Haudenosaunee). The Mississauga people who controlled the northern shore of Lake Ontario prior to British settlement are Ojibwa, or Anishinaabek. ${ }^{12}$ Iroquoian nations include the Wendat (sometimes referred to by the French term Huron) and the Six Nations Confederacy (comprised of the Mohawk, Oneida, Cayuga, Onondaga, Seneca, and Tuscarora nations). ${ }^{13}$ In the mid-eighteenth century, the Wendat lived in territories to the south of Georgian Bay, whereas the Six Nations lived across Lake Ontario in what is now northern New York State. ${ }^{14}$

Lake Ontario and the land that encircled it had been Iroquoian territory for at least a thousand years prior to European contact. ${ }^{15}$ After $1000 \mathrm{CE}$, the Iroquoian communities spread across the Toronto water systems were multi-ethnic cosmopolitan villages populated mainly by Wendat and Tionontati (Petun) people. ${ }^{16}$ Over several hundred years until around 1600, the Wendat and Tionontati people gradually moved their villages north to the Georgian Bay region, though the Toronto area remained Wendat hunting ground

\footnotetext{
${ }^{12}$ These names vary in different cultural contexts; in the United States, the Ojibwa nation is referred to as Chippewa. "Anishinaabek" is an Algonkian word meaning "the people." See Ruth Phillips, Trading Identities: The Souvenir in Native North American Art from the Northeast, 1700-1900 (Montreal: McGill-Queen's University Press, 1999), xvi. Other Anishinabek groups are referred to as Algonkians, Nipissings, Odawa, and Potowatomi. Linguistically, these groups speak Algonkian languages. Algonkian groups lived primarily north of Lake Ontario - in territories that include Georgian Bay, Lake Nipissing, and the Ottawa Valley, but whose larger homeland and military alliances included territories stretching from the eastern end of Lake Ontario to Lake Winnipeg and the Turtle Mountains of North Dakota. See Peter Schmalz, The Ojibwa of Southern Ontario (Toronto: University of Toronto Press, 1991), 4.

${ }^{13}$ The Tuscarora nation joined the confederacy in 1722 , which is why the confederacy is sometimes referred to as the Five Nations Confederacy.

${ }^{14}$ Donald B. Smith, "The Dispossession of the Mississauga Indians: a Missing Chapter in the Early History of Upper Canada," Ontario History 73, no. 2 (1981): 68.

${ }^{15}$ Freeman, "Toronto," 44.

${ }^{16}$ Freeman, "Toronto," 45.
} 
until 1649. The Five Nations Iroquois Confederacy drove the Wendat out of the Toronto region in a series of battles from 1649-1650. After successfully defeating the Wendat, the Iroquois attacked allied and neutral nations in the region. Several Algonkian groups, allied with the Wendat and the French as trading partners, were attacked and peace was not established until 1666. During this time, French fur traders began mapping the Toronto area in progressively greater detail, making note of the Seneca trading villages Teiaiagon (near the mouth of the Humber River) and Ganetsakwyagon, both of which were destroyed following French attacks on the Seneca in $1687 .{ }^{17}$

Oral traditions and colonial records indicate a series of battles took place between the Mississaugas and the Iroquois Confederacy in the last decades of the seventeenth century that moved the Iroquois south of Lake Ontario into what is now New York State. ${ }^{18}$ Through diplomatic treaty, the Mississaugas became allied with the Five Nations Confederacy, and inherited control of the north shore of Lake Ontario. The Mississaugas also became participants in the Convenant Chain, an alliance between the Iroquois Confederacy and the Dutch, a relationship the English sustained as they gained control of New York in $1664 .^{19}$

By 1720 , the Mississaugas had established small villages across southern Ontario, many along the waterways that flow in and through the Toronto region. Their population was never very high (approximately 1,000-1,500 people), but because of their extensive military alliances their political power was significant. ${ }^{20}$ The Mississaugas in the Toronto area were members of a larger Anishinaabek military alliance that extended from the

\footnotetext{
${ }^{17}$ Freeman, "Toronto," 46.

${ }^{18}$ See Freeman, "Toronto," 46-9.

19 Freeman, "Toronto," 48.

${ }^{20}$ Freeman, "Toronto," 50.
} 
Ottawa River to the western plains, and was a leading power in the upper Great Lakes region in the seventeenth and eighteenth centuries. ${ }^{21}$

Europeans have travelled through the Toronto region since the early seventeenth century, though European trading goods preceded their arrival by nearly two generations, transported into the region through vast Indigenous trading networks that criss-crossed the North American continent. ${ }^{22}$ French visitors in the seventeenth century came to the Toronto region either as fur traders or as missionaries, and integrated their interests and cultural practices into existing trade and ceremonial systems. French fur traders had traded with Seneca villages in the late seventeenth century, and set up trading forts once the region was controlled by the Mississaugas. The French built a trading fort near the mouth of the Humber River in 1720, and again in 1750. The French Fort Rouillé was built on what is now the CNE grounds in 1751 and was deliberately burned to the ground by French soldiers fleeing the area after the British seized control of the Niagara region at the end of the Seven Years War. ${ }^{23}$ After Fort Niagara was captured by the British in 1759 , the French abandoned Fort Rouillé, though independent French and Scottish traders remained in the region, continuing to sell European commodities, rum in particular. $^{24}$

In sum, the land in and around Toronto, like the communities that have peopled it, has a dynamic and ever-shifting history of occupation and significance. The HuronWendat nation whose current homeland is Wendake, near Quebec City, claim Toronto as an ancestral homeland prior to their exile in the middle of the seventeenth century.

\footnotetext{
${ }^{21}$ Freeman, "Toronto," 50. See also D. Peter McLeod, "Anishinabeg Point of View: The History of the Great Lakes Region to 1800 in Nineteenth-Century Mississauga, Odawa and Ojibwa Historiography," Canadian Historical Review 73, no. 2 (1992): 202.

22 Bobiwash, "The History of Native People," 10.

${ }^{23}$ Freeman, "Toronto," 51.

${ }^{24}$ Robinson, "Toronto Carrying Place," 46.
} 
Members of the Iroquois Confederacy claim long-term residence in the Toronto region that has been interrupted at several intervals over the past thousand years. By 1701, the Toronto area was under Mississauga control, and it was with the Mississaugas of the Credit River (where their council fire was located) that the British entered into land negotiations in the late eighteenth century, following the American Revolutionary War.

\section{From Middle Ground to Divided Ground}

The history of land commodification in the Toronto area began with a progressive shift in international relations in the Great Lakes region that eliminated the political power of Indigenous people. This shift occurred in the latter half of the eighteenth century, and ended a nearly two-hundred-year period whereby both Indigenous and European communities understood themselves to be mutually dependent upon each other as allies and neighbours. ${ }^{25}$ To be clear, this was not a time characterized by constant peace or prosperity. There were times of significant conflict. However, the Great Lakes region prior to the mid-eighteenth century has been described as a borderland society, an intercultural zone described as "the place in between: in between cultures, peoples, and in between empires and the nonstate world of villages. ${ }^{, 26}$ Richard White has named the Great Lakes region during this time the "middle ground," a "common, mutually comprehensible world in the region around the Great Lakes ... in this world the older worlds of the Algonquians and of various Europeans overlapped, and their mixture created new systems of meaning and of exchange.,27

\footnotetext{
${ }^{25}$ Richard White, The Middle Ground: Indians, Empires, and Republics in the Great Lakes Region, 16501815 (Cambridge: Cambridge University Press, 2010), x.

${ }^{26}$ White, Middle Ground, $\mathrm{x}$.

${ }^{27}$ White, Middle Ground, ix-x.
} 
The events I will summarize in the following pages illustrate how the middle ground became eroded by the competition between the new American republic and the British Empire to secure new boundaries that eliminated the political significance of Indigenous people as intermediaries between warring European powers. In the shift from a borderland society to formalized international borders, both the state of New York and province of Upper Canada built "state power from a web of private properties ... systematically [consuming] native land and [foreclosing] the [political] alternatives envisioned by [Indigenous leaders]. ${ }^{, 28}$ Consequently, Indigenous people "ceased to have the power to force whites onto the middle ground. Then the desire of whites to dictate the terms of accommodation could be given its head." 29

In the following pages, I document a series of events that led to the establishment of the province of Upper Canada, and the township of York, later to become the City of Toronto. These events demonstrate the abrupt shift in policy by the British towards Indigenous allies. Rather than sustain the generations-old alliances informed by mutual benefit and co-existence, British colonial officials began pursuing aggressive policies of land cession, European settlement, and Indigenous dispossession in an effort to compete with the American republic for territorial control. As Alan Taylor has argued, rather than having international relations triangulated in the middle ground society, "the republic and the empire defined a border that controlled [Indigenous people]." ${ }^{30}$ Facilitating mass European settlement was a political strategy to privatize land use and land ownership north of the American border. Mass European settlement created a defensive buffer between British territory and the Americans, and was one way to finance state-building.

\footnotetext{
${ }^{28}$ Taylor, Divided Ground, 407.

${ }^{29}$ White, Middle Ground, xv.

${ }^{30}$ Taylor, Divided Ground, 405-6.
} 
The land cessions negotiated at the end of the eighteenth century in the Toronto area, combined with the granting of private land title to settlers, created the settler colonial land economy that continues to exist today. In order to create neighbourhoods like Wychwood Park, made up of many privately held lots, Indigenous political and territorial power had to first be eliminated.

\section{The Context for Creating Private Property Out of Indigenous Land}

Following the defeat of the French in 1759, British colonial policy towards Indigenous people in the Great Lakes region shifted almost immediately. Commander-inChief Jeffrey Amherst ordered Superintendent of Indian Affairs, Sir William Johnson, to cease annual "presents" to Indigenous allies. Payments of European trade goods had been regularly made to Indigenous allies by the British to sustain relationships of good faith. Despite Johnson's disagreement, Amherst ceased to give annual payments, and allowed land to be sold to speculators, violating the terms of intercultural trade that had been sustained for generations in the Great Lakes. In response, a coalition of tribes in the Great Lakes and Ohio Valley captured nine British frontier forts, killing 2,500 British soldiers and settlers, and returning the northwest to Indigenous control. These attacks are known as "Pontiac's War" (1763-1766), named after the Ottawa chief, Obwandiyag, whom the British called Pontiac.

Significantly, some Mississaugas participated in the attacks, but none were from the Toronto region. Chief Wabbiccomicot from the Toronto area was a key leader in ending the siege of Fort Detroit, one of the most significant events in Pontiac's war. Chief Wabbicommicot had personal relationships with both Sir William Johnson and Major 
Henry Gladwin, the commander of Fort Detroit, which had been blockaded by Pontiac's army for months in 1763. Because of Wabbiccomicot's diplomatic influence, the siege of Fort Detroit ended without British surrender. Wabbiccomicot's role is significant to the history of the Toronto region - it suggests that the Mississaugas of the Credit River understood themselves to be allied with the British from at least the 1760s. It was in this context that land cessions in the Toronto region to the British should be understood.

Within a month of Pontiac's retreat from Fort Detroit, King George issued a royal proclamation that recognized that lands in the Great Lakes region were Indian hunting grounds and off limits to settlers. The Royal Proclamation of 1763 (the Royal Proclamation) directly responded to the objections named by Pontiac and his supporters, by forbidding the sale of land to speculators prior to negotiated treaty with Indigenous people. The Royal Proclamation continues to be recognized by Canadian courts today as the legal basis for treaty protocols in Canada.

\section{The Royal Proclamation of 1763}

Royal proclamations were issued several times a year over the course of the seventeenth and eighteenth centuries by British monarchs mandating activities from war and land use policy, to recognized public celebrations and holidays. The royal proclamation that has been used in British and Canadian courts to recognize Aboriginal land title in Canada was issued on October 7, 1763, months after Britain and France 
signed the Peace Treaty of Paris that ended their imperial war in North America, ${ }^{31}$ and the same month that Pontiac's army abandoned the siege of Fort Detroit.

The Royal Proclamation established two main changes to British imperial organization in North America. First, the Proclamation announced the establishment of four new colonies and jurisdictions: Quebec, East Florida, West Florida, and Grenada. The document also formalized the annexation of Cape Breton and St. John's Island (now Prince Edward Island) to Nova Scotia. Second, the Royal Proclamation outlined how (with the exception of Grenada) the newly formed colonies would establish governments, local laws, and judicial systems "as near as may be agreeable to the Laws of England.",32 As recognition for those who had fought in the war against France, the Proclamation outlined the policy for land grants for military personnel, with standardized grant sizes noted according to rank.

The Proclamation also asserted a framework for territorial expansion on the continent, insisting upon the negotiation and purchase of territories from "Indians" prior to surveying and settlement. Specifically, the Proclamation noted that:

The several Nations or Tribes of Indians, with whom we are connected, and who live under Our Protection, should not be molested or disturbed in the Possession of such Parts of Our Dominions and Territories as, not having been ceded to, or purchased by Us, are reserved to them, or any of them, as their Hunting Grounds ... no Governor or Commander in Chief in any of Our other Colonies or Plantations in America, do presume, for the present, and until Our future Pleasure be known, to grant Warrants of Survey, or pass Patents for any Lands ... which, not having been ceded to, or purchased by Us as aforesaid, are reserved to the said Indians, or any of them. ${ }^{33}$

\footnotetext{
${ }^{31}$ A different Treaty of Paris would be signed in 1783 between the British and the Americans, formally ending the Revolutionary War and establishing a boundary between the American republic and British territories.

32 "Royal Proclamation of 1763," Canada Watch (Fall 2013): 14.

33 "Royal Proclamation," 15. Emphasis mine.
} 
The Proclamation, then, made it clear that territories not currently settled by Europeans could only be surveyed for settlement once they had been purchased through a publicly negotiated process. Until territories were ceded or purchased, the Crown considered those lands to be "reserved to [Indians]."

Further, the Proclamation ordered that any "Persons ... charged with Treasons, Misprisions of Treasons, Murders, or other Felonies or Misdemeanors" who "fly from Justice and take Refuge in the [Indian] Territory" should be escorted back to colonial territories to stand trial for their crimes. ${ }^{34}$ "Indian Territory," then, was considered outside the rule of colonial law, in addition to being reserved for Indian hunting.

Because of the protocol that recognized that land needed to be purchased before it was settled, the Royal Proclamation has been used in both British and Canadian courts by First Nations to argue for the recognition of Aboriginal land title, particularly in British Columbia, where few treaties were signed prior to mass European settlement. Further, the Royal Proclamation has been relied upon as the referent recognized by the colonial courts as a way of assessing whether treaty agreements and land use took place in a legal way.

A further distinction is made in the Royal Proclamation about the right to purchase Indian lands. After asserting that lands not settled were reserved to Indians from whom the land could be purchased, the Proclamation limits potential land purchasers to the Crown itself, creating a monopolized market for land negotiations. The Proclamation reads:

We do, with the Advice of Our Privy Council, strictly enjoin and require, that no private Person do presume to make any Purchase from the said Indians of any Lands reserved to the said Indians, within those Parts of Our Colonies where We have thought proper to allow Settlement; but that if, at any Time, any of the said Indians should be inclined to dispose of the said Lands, that same shall be

\footnotetext{
34 “Royal Proclamation," 15.
} 
purchased only for Us, in Our Name, at some publick Meeting or Assembly of the said Indians to be held for that Purpose by the Governor or Commander in Chief of Our Colonies respectively. ${ }^{35}$

Therefore, the Proclamation outlines not only that the Crown must negotiate the transfer of land title prior to settlement, but that the Crown is the only party to whom land may be sold.

\section{Treaty of Niagara}

In July of 1764, Superintendent of Indian Affairs Sir William Johnson met with two thousand delegates from twenty-four nations at Fort Niagara to negotiate an alliance between British and Indigenous nations. Three-quarters of those assembled were Anishinaabek. Chief Wabbiccomicot from Toronto attended as one of twelve Anishinaabek chiefs. During the meetings, Johnson paid special tribute to Wabbicommicot, thanking him for his diplomatic work and gifting him a belt of wampum that depicted Fort Niagara with a road running through it and two figures on each side, symbolizing a peaceful relationship. A second belt was conferred at the Treaty of Niagara meeting that recognized a nation-to-nation relationship between the twenty-four First Nations, who are depicted as connecting the land on North America to a boat symbolizing the British presence.

The council at Niagara formalized the terms of the 1763 Royal Proclamation according to the intercultural system of negotiation and alliance that existed in the Great Lakes region. Because of the exchange of wampum at Niagara in 1764, the Royal Proclamation of 1763 is considered a treaty by the Mississaugas of the Credit River.

\footnotetext{
35 "Royal Proclamation," 15. Emphasis mine.
} 
Darlene Johnston cautions: "In accepting the Twenty-Four Nations belt, the Anishinaabeg bound the British Crown [to] a perpetual promise that their alliance would be life-giving and sustaining, not impoverishing. These two belts, and the promises embedded in them, form the foundation of the British-Anishinaabeg Treaty Alliance. Subsequent agreements must be read in light of these original promises of protection and sustenance." ${ }^{36}$ From the 1760s onwards, it was clear that the Mississauga of the Credit River understood themselves to be allied with the British as political partners. Further, Wabbiccomicot's diplomacy positioned the Toronto-area Mississaugas distinctly as privileged allies of the British. The memory and understanding of these nation-to-nation agreements informed the willingness, on the part of the Mississaugas of the Credit River, to cede land that included the Toronto Carrying Place twenty years later. The allegorical details on the wampum belts exchanged during the Treaty of Niagara demonstrate promises on the part of the British that mutual benefit and a sharing of resources would result from land negotiations in the future.

\section{Treaty of Paris}

In 1783, the British signed the Treaty of Paris with the Americans, ending the Revolutionary War and ceding western territories to the new republic of the United States. This was a key moment in the progressive elimination of Indigenous political power. By ceding western territories to the Americans, the British effectively betrayed their promises to their Indigenous allies, specifically the Six Nations, who could no longer count on the British forbidding settlements west of the colonial border without prior

\footnotetext{
${ }^{36}$ Darlene Johnston, "Connecting People to Place: Great Lakes Aboriginal History in Cultural Context," report prepared for the Ipperwash Commission of the Inquiry, August 2004, https://www.attorneygeneral.jus.gov.on.ca/inquiries/ipperwash/transcripts/pdf/P1_Tab_1.pdf, 15.
} 
negotiation. Six Nations leaders were furious that the British no longer maintained treaty promises in what was now referred to as American territory. In particular, Mohawk leader Joseph Brant had been advocating for a border dictating the limits of the republic's territory that ran north-south rather than east-west. Brant's proposal would include an "Indian country" to the west of the colonial settlements. Brant's proposal envisioned a role for the Iroquois as landowners leasing out land to settlers as tenants. By establishing a border with the American republic that ran east-west rather than north-south, the British effectively abandoned their earlier promises to defend Indigenous sovereignty south of the Great Lakes and west of the American colonial settlements. Americans then began expanding westward, exerting their political power by "restricting [Indigenous peoples'] movements, regulating their trade, demanding further land cessions, and enforcing legal jurisdiction over murder. ${ }^{37}$

Similarly, the British focused their attention north of the border, "becoming more obsessed with restricting native communication, diplomacy, and property on [the British] side of the line. By managing [Indigenous people], the British sought predictable military auxiliaries for a future war with Americans." ${ }^{38}$

The British immediately began negotiating land cessions from the Mississaugas for the resettlement of Loyalists. The first cession was granted to the Mohawks, led by Joseph Brant, as compensation for having signed the Treaty of Paris. The Mohawks were granted land near what is now Grand River in 1784. Throughout the 1780s, the British negotiated the surrender of several large tracts of land from the Mississaugas. These land cessions were intended to be given to Loyalists as land grants. In 1781, 1782, 1784, 1787,

\footnotetext{
${ }^{37}$ Taylor, Divided Ground, 405.

${ }^{38}$ Taylor, Divided Ground, 405.
} 
and 1788 various tracts of land along the shores of the St. Lawrence River, Lake Erie, and Lake Ontario were ceded to the British, including land in the Toronto area.

Loyalists were granted free land as compensation for their service and losses due to war. In addition to free land, Loyalists were granted tools and provisions for their first two years. The British government built and operated gristmills and sawmills to assist with the transition. Between 1783 and 1785, ten thousand Loyalists immigrated to what would become Upper Canada, immediately outnumbering the Mississaugas tenfold. It is estimated that when Loyalists began immigrating to what would become Upper Canada, that approximately one thousand Mississaugas lived in seasonal, politically distinct, mobile camps of a dozen families each, hunting and fishing in territory between the St. Lawrence River to the east, Lake Huron to the west, the Ottawa River to the north, and Lakes Erie and Ontario to the south. ${ }^{39}$

The Mississaugas welcomed Loyalist refugees in order to improve their relationship with British colonial officials, who had greatly restricted the regular exchange of payments since the 1760s. As Alan Taylor argues, Mississauga chiefs understood the land cessions to be gifts granted to the British as part of an ongoing relationship. Having gifted land to the British, the Mississaugas expected annual increased payments, and benefit from the agricultural surplus during harvest time as a form of annual rent. ${ }^{40}$ This expectation explains the relatively low payment received for land in the form of provisions such as ammunition and clothing. As nomadic people, the Mississaugas saw a benefit in welcoming farmers who would establish farms to supplement their hunting and gathering economy.

\footnotetext{
${ }^{39}$ Taylor, Divided Ground, 129.

40 Taylor, Divided Ground, 130.
} 
The British, however, would later claim the land cessions to be a one-time purchase that transferred exclusive ownership rights to the land. When settlers began arriving in far greater numbers than the Mississaugas had expected, they were granted title to individual lots of land, and considered the land to belong to them. Consequently, the physical environment of the Great Lakes region was radically transformed. Forests were cleared to build roads, pastures, and harvest wood for building houses. Sawmills and tanneries polluted rivers, and fish populations were harmed by the introduction of soap into the water systems. ${ }^{41}$ As wild game populations decreased, Mississauga hunters began killing cattle instead, angering settler farmers. Increasingly, settlers began to "[treat] the Mississaugas with contempt as idle beggars, driving them away from cabin doors. Rather than accept their status as guests in Indian country, the settlers acted as if they owned the land and had extinguished all native rights. To roust natives, the settlers burned their wigwams, stole their guns, and killed their dogs."42 Granting settlers title to individual lots of land created conditions for settlers to weaponize individual property lines and disavow any social or economic practice based on land sharing or mutual benefit. As immigration intensified in the Great Lakes region, original land grants were then subdivided for steadily increasing profit, establishing long-term settler wealth contingent upon Indigenous territorial dispossession.

In order to secure their territory against the threat of American invasion, the British encouraged mass immigration to Upper Canada. In preparation for mass settlement, the British negotiated land cessions in the Toronto area in the 1780s. What follows is a detailed account of the cession of land in the Toronto area, a long and

\footnotetext{
${ }^{41}$ Taylor, Divided Ground, 131-2.

${ }^{42}$ Taylor, Divided Ground, 132.
} 
confusing process that started with the Toronto Purchase negotiations in 1787 . The Purchase was finally confirmed in 1805, though the Mississaugas of the Credit River continued to dispute the terms in which the agreement was made. A land claim settlement was finally reached in 2010 .

\section{The Toronto Purchase}

The strategic importance of the Toronto Carrying Place for the British intensified following the American Revolution. Toronto offered access to northwest fur trading routes away from American military threat. Colonial authorities made arrangements to negotiate the cession of the Toronto Carrying Place from the Mississaugas of the Credit River. In the fall of 1787, Superintendent of Indian Affairs Sir John Johnson (Sir William Johnson's son) met with several Mississauga bands at the Bay of Quinte to negotiate the Mississauga cession of the Toronto region to British control. Six hundred and twenty-six Anishinaabek attended the meeting. ${ }^{43}$ What exactly transpired at the Quinte meeting is poorly recorded in both written and oral records. Colonial and Indigenous representatives have always acknowledged that a provisional agreement was reached ceding land in the Toronto region, though how much and for what cost remains unclear to this day. The surrender document did not describe physical boundaries for the land in question, nor were chiefs from appropriate bands named. At the bottom of the document, the names of three chiefs - Wabakinine, Neace, and Pakquan, including their totems - appear on pieces of paper that were glued to the surrender deed. ${ }^{44}$

\footnotetext{
${ }^{43}$ Freeman, "Toronto," 57. See also Percy J. Robinson, "The Chevalier de Rocheblave and the Toronto Purchase," Royal Society of Canada Transactions 31, third series (1937): 140.

${ }^{44}$ Surrender, September 23, 1787, in Canada, Indian Treaties and Surrenders, from 1680-1890 (Ottawa, Brown Chamberlin, 1891; reprint, Saskatoon: Fifth House Publishers, 1992), 1: 32-4.
} 
The following summer, in 1788, surveyor Alexander Aitkin began surveying land at Toronto. His survey measured fourteen miles from Scarborough Heights to the Etobicoke River. ${ }^{45}$ During Aitken's 1788 survey, he was stopped at both the eastern and western boundary points by Mississauga chiefs who objected to his calculations. Aitkin's east-west boundary measured fourteen miles, while the Mississauga memory of the Toronto Purchase made at the Bay of Quinte the year earlier was cited as ten miles. As historian Percy Robinson notes, "obscurity enters at this point." negotiations were required between Mississauga chiefs and high-ranking British officials before the survey could continue. ${ }^{47}$ Aitken eventually abandoned his survey once he reached the western boundary at the Etobicoke Creek for fear of Mississauga attack if he were to survey further. ${ }^{48}$

Mississauga discontent continued to be communicated to colonial officials about the legitimacy of the Toronto Purchase. On March 2, 1790, John Butler, chief Indian agent at Niagara, wrote Sir John Johnson that "the Mississaugas complain at being disappointed in their payment for the lands they sold Government when His Lordship (Lord Dorchester) and you passed Toronto (in 1788). ${ }^{, 49}$ Despite Aitken's survey and his township plan, no permanent British settlement was formed at Toronto in the late 1780s.

\footnotetext{
${ }^{45}$ Percy Robinson, Toronto During the French Regime 1615-1793 (Toronto: University of Toronto Press, 1965), 166-8.

${ }^{46}$ Robinson, "Chevalier," 140.

${ }^{47}$ Robinson, Toronto During the French Regime, 166-8.

${ }^{48}$ Freeman, "Toronto," 90.

${ }^{49}$ Quoted in Robinson, "Chevalier," 141.
} 


\section{Creating Upper Canada}

In 1791, the Constitution Act created two provinces: Upper Canada (now

Ontario), and Lower Canada (now Quebec). John Graves Simcoe was named lieutenant governor of Upper Canada, and established the seat of government at Newark (Niagaraon-the-Lake), a British military centre and hub for Loyalist refugees. In 1793, Simcoe visited Toronto from Niagara and immediately began planning to create a temporary provincial capital at Toronto, further away from the American border.

Simcoe arrived at Toronto in July of 1793 with soldiers from the Queen's Rangers regiment to set up a fort. On August 26, 1793, he christened the site "York" to honour the Duke of York. Alexander Aitken was again commissioned to survey a second town site, this time further east and smaller than the original plan. Importantly, York was never intended to be a major centre; Simcoe wanted to establish a much larger military base at Kingston, and a government centre in London, Ontario on the river he named Thames. York was intended to be a temporary capital, and its initial townsite reflects Simcoe's limited ambition for the site. For instance, the best lands at the harbour entrance were reserved for military purposes, and land for the town was allocated near the mouth of the Don River - next to the swampy valley. There were no provisions made for the planning of any public buildings - the townsite was planned to host military officials, government buildings, and little else.

Unsurprisingly, government officials in Newark were reluctant to move to the muddy, tiny town of York. In order to entice them, Simcoe granted hundred-acre lots running north from the northernmost boundary of the small townsite, Lot Street (later to be renamed Queen Street), up to what would become Bloor Street. There were three types 
of land grants in the immediate vicinity of the Fort at York: town lots for homes in the small town itself, one hundred-acre park lots running from Lot Street to Bloor Street, and two hundred-acre farm lots running from Bloor Street to what would become St. Clair Avenue. The hundred-acre park lots would end up becoming significant for the City of Toronto. It was out of those park lots that the city would eventually be built, through the subdivision of privately held lands as opposed to centralized urban planning, much to the chagrin of the future residents of Wychwood Park, who would actively advocate for centralized urban planning one hundred years later.

Simcoe's enticement plan worked. In the fall of 1793 , there was a "scramble" $" 50$ for lots in the planned town of York as elite officials applied for land before the Executive Council could meet and establish rules curtailing land speculation. Many of the first park lots granted went to members of Simcoe's inner circle. ${ }^{51}$ By granting large tracts of land to elite members of society, Simcoe hoped to establish a landed aristocracy in the new province that would "lessen the undue weight of the democratic influence" have contributed to the American Revolution.

With a townsite surveyed, lots beginning to be granted, and provisional housing being built, Simcoe wrote to colonial administrators asking for copies of the surrender deeds to the Carrying Place and the Toronto Purchase. In January of 1794, he received a letter from Governor-General Dorchester regarding the 1787 surrender document:

a Plan (Copy of which I believe was given to you) has been found in the Surveyor General's Office, to which is attached a blank deed, with the names or devices of three Chiefs of the Mississauga Nation, on separate pieces of paper annexed thereto, and witnessed by Mr. Collins, Mr. Kotte, a Surveyor, since dead, and Mr.

\footnotetext{
${ }^{50}$ Edith Firth, The Town of York 1793-1815 (Toronto: Champlain Society, 1962), xxxiv.

${ }^{51}$ Edith Firth, Town of York, xxxiv.

${ }^{52}$ Quoted in Lillian Gates, Land Policies of Upper Canada (Toronto: University of Toronto Press, 1968), 25.
} 
Lines, Indian Interpreter, but not being filled up, is of no validity, or may be applied to all the Land they possess; no Fraud has been committed or seems to have been intended. It has, however, an omission which will set aside the whole transaction, and throw us entirely on the good faith of the Indians for just so much Land as they are willing to allow, and what may be further necessary must be purchased anew, but it will be best not to press that matter or show any anxiety about it. ${ }^{53}$

In response, Simcoe proposed to have the blanks on the document filled in, in the presence of the two surviving chiefs who had participated in the original negotiations. ${ }^{54}$ Dorchester advised against that plan due to Sir John Johnson's absence from Canada at the time. Johnson, as superintendent general, was required to be present at all land negotiations with the Mississaugas, in accordance with the Royal Proclamation of 1763 , just as he had also been present at the Bay of Quinte negotiations in $1787 .^{55}$

In December 1794, Dorchester wrote to Alexander McKee, deputy superintendent general of Indian Affairs, enclosing a copy of the blank surrender deed from 1787. Dorchester explained that with regards to the Toronto Purchase, "proceedings are so informal and irregular as to invalidate and set aside the whole transaction" and that the deed itself was "of no validity or value." $" 56$ Nonetheless, the British settlement of York continued.

During the first few years at York, the settlement was effectively a military camp. With the exception of surveyors in the area, all men were soldiers. The extreme weather conditions and inadequate housing and food supply made life difficult. The isolation and

${ }^{53}$ Lord Dorchester, Captain General and Governor in Chief, to J.G. Simcoe, Lieutenant Governor, Upper Canada, January 24 1794, in E.A. Cruikshank, ed., The Simcoe Papers (Toronto: Ontario Historical Society, 1924), 2: 137. Emphasis mine.

${ }^{54}$ J.G. Simcoe, Lieutenant Governor, Province of Upper Canada, to Lord Dorchester, Captain General and Governor in Chief, March 3, 1794, in Cruikshank, Simcoe Papers, 2: 174.

${ }^{55}$ Lord Dorchester, Captain General and Governor in Chief, to J.G. Simcoe, Lieutenant Governor, Upper Canada September 22, 1794, in Cruikshank, Simcoe Papers, 3: 104.

${ }^{56}$ Lord Dorchester, Captain General and Governor in Chief, to Alexander McKee, Deputy Superintendent General, Department of Indian Affairs, December 24, 1794, Record Group 10, vol. 8, 8124-811, Library and Archives Canada. 
lack of farm workers made the town vulnerable to famine. In 1796, Simcoe issued provisions to town residents to prevent starvation. ${ }^{57}$ Labour to build houses was expensive and hard to find. Simcoe developed neuralgia in 1796 and returned to England on a leave of absence, and Peter Russell took his place. Government officials, who continued to procrastinate on moving to York from Newark, were finally ordered to relocate in 1797. Skilled tradesmen followed the migration of government business. Slowly, industries were established to meet local needs.

As York's population expanded, the terms of the Toronto Purchase continued to be contested by Mississauga leaders. By the mid-1790s, there were increasing examples of conflict between Mississaugas and colonial officials because of different interpretations of cession boundaries, intensive and unanticipated settlement of vast tracks of Mississauga territory, downward pressure on land prices, and racist violence from settlers. ${ }^{58}$ Reports of Indigenous people being chased off settler farms with guns and dogs raised concerns about settler racism and a profound misunderstanding about the function of land use and conceptions of private property. ${ }^{59}$ Pollution from European soap, and waste from sawmills infecting the water systems, were limiting the ability of the Mississaugas to sustain traditional land use patterns, and informing their assumptions about what territories they could afford to cede during negotiations.

\footnotetext{
${ }^{57}$ Firth, Town of York, lii.

${ }^{58}$ Examples include a surveying party being stopped, while conducting a survey of Yonge Street, by Chippewa and Mississauga representatives who claimed no treaty had been agreed to that allowed the British survey of Indigenous lands. See Leo Johnson, "The Mississauga-Lake Ontario Land Surrender of 1805," Ontario History 83, no. 3 (1990): 234. Johnson also discusses how a survey party was warned by Mississaugas that the treaty that allowed the surveyors to be present at the Thames River had been agreed to by a Chief who had no authority to do so.

${ }^{59}$ Minutes of a Council with the Mississaugas, held Aug. 1, 1805, Record Group 10, Indian Affairs, Red Series, Lieutenant Governor's Correspondence vol. 1, 294-6, Library and Archives Canada.
} 


\section{Negotiating the Mississauga Tract}

Throughout the 1790s, British officials continued to pursue expanded territorial control of the lands adjacent to Toronto. In the interests of linking the Niagara settlements to the Loyalist territories to the east of Toronto, the British attempted to negotiate the cession of what was called the "Mississauga Tract" - the territory from the Etobicoke Creek to Burlington Bay. With the Toronto Purchase still a contested agreement, the Mississaugas were reluctant to negotiate the cession of the Mississauga Tract until their relationships with settlers and the colonial government improved.

Two of the most symbolically devastating events to highlight the growing violence between colonial and Indigenous people were the murders of two significant Mississauga chiefs: The Snake was murdered at Kingston in 1792, and Wabakinine was murdered at York in August 1796. The murder of Wabakinine mobilized Mississaugas to demand reparations from the British, and put a halt on land negotiations of the Mississauga tract.

Peter Russell began to fear a war between the British and the Mississaugas and their allies. He wrote to Simcoe that the Mississaugas were stopping more surveys of land, and warned, "I cannot, however, shake off my apprehensions that some unfortunate family may yet, notwithstanding fall a sacrifice to their resentment for Wabukanyn had many relations among the Chippewas and Lake Indians, and was greatly loved by them. ${ }^{, 60}$ By April of 1797, Russell was begging Governor Prescott for military support at York, because of reports that an attack was imminent, planned as a revenge for

\footnotetext{
${ }^{60}$ Johnson, “Mississauga,” 236.
} 
Wabakinine's death. ${ }^{61}$ Mississauga discontent was intensifying. British payments had been discontinued in the 1790 s due to intense pressure to keep expenses down. No Indian agent had been appointed to York. At a Council of Lake Simcoe Chippewas held at York in 1796 , chiefs complained that they had been "thrown away" by the government. ${ }^{62}$

Meanwhile, Joseph Brant, leading the Mohawk settlement at Grand River, began to actively oppose the high profit margins achieved by British officials by negotiating land cessions so cheaply. He negotiated his own land deals at market rate, which angered the British, and piqued Mississauga interest. Impressed by Joseph Brant's sale of Block I of the Grand River Tract (Dumfries Township) for $£ 8,842$, or 22.5 pence an acre, the Misssissaugas began to demand a higher price for land. ${ }^{63}$ On August 21, 1797, the Mississaugas sold a plot on Burlington Bay to the government for $£ 75$ 2s $6 \mathrm{~d}$, or just over 5 pence per acre. In the fall, when the British wanted to buy the land between the Etobicoke Creek and Burlington, the Mississaugas demanded a price of 3 shillings, or 4 pence an acre. At the time, the price was unheard of, and such a high initial price for the land greatly threatened the large profit margin the British were relying on in order to expand their colonial assets. Justice William Dummer Powell blamed the example set by Joseph Brant of selling land at market value. He wrote, "The unreasonable nature of this demand on the part of the Indians, may be estimated by Comparison with past purchases, where the value of the presents given, in return for the Cession of the Land, has, not, in one Instance, exceeded two pence per Acre."64

\footnotetext{
61 Johnson, "Mississauga," 236.

62 Johnson, "Mississauga," 236.

${ }^{63}$ For more on Brant's land deal, see Rev. John Stewart's "Report to the Society for the Propagation of the Gospel," October 11, 1798, in Charles M. Johnston, The Valley of the Six Nations (Toronto: Champlain Society, 1964), 65-6.

${ }^{64}$ Quoted in Johnson, "Mississauga," 238.
} 
In the spring of 1798 , the Mississaugas formally appointed Brant to be their legal guardian and agent in all future land sales. ${ }^{65}$ Shortly thereafter, Major Shank (who that year was granted one of the plots of land upon which Wychwood Park would eventually be built) received a speech from Chief Wabanip who announced that the Six Nations and Mississauga were going to become one people: "In future the [Six] Nations expect to see us every spring at their Council fire to consult with each other, \& if any injury happen one or the other, they were not to do anything without first consulting each other in Council ... and I now tell you that we were very much pleased at what our Brother Capt Brant told us. $" 66$

The fear of Mississauga violence, made more powerful through their alliance with Joseph Brant, concerned the Russell administration. The Upper Canada Executive Council asked the Land Board to study the situation and propose a land cessions plan that would ensure low prices and the sustained carrying out of a mass settlement plan.

\section{Settler Colonial Depression of Land Prices}

The Land Board responded by proposing a three-pronged solution to settling Mississauga grievances and proposing a way of purchasing the Mississauga Tract. The Land Board's report explicitly mentioned that there were settler colonial fears that the Mississauga were catching on to the high profit margin that was at stake in the current arrangement. In order to ensure it could continue, the Land Board proposed a strategy:

First, to refuse to negotiate any further land cessions until the plan was carried out. Furthermore, no land deals negotiated between Mississauga communities and any other

${ }^{65}$ Quoted in Johnson, "Mississauga," 239.

66 "A Speech Delivered to Major Shank by Wabanip \& several Other Chiefs of the Mississaugas in presence of the Officers of the Garrison, $17^{\text {th }}$ May, 1798," quoted in Johnson, "Mississauga," 240. 
parties would be approved, thereby putting downward pressure on the price of Mississauga land. Second, the discontinuation of presents that acknowledged past friendship and alliances, and instead the giving out of presents only for "good behaviour." Third, and perhaps most duplicitous, was a directive to "foment jealousy at all costs between the Mississauga and the Six Nations" so that their alliance with each other would weaken.

In the eight years that this plan was in effect, the Mississaugas became increasingly dependent upon colonial presents, because their traditional way of life was impossible to sustain after the settlers polluted the waters and forbade them from sharing the land.

In a letter written on September 11, 1797, Lord Portland, the Colonial Secretary, advised Russell that the appointment of an Indian agent at York would ensure local Mississaugas would have fewer excuses to travel to Brant's region (closer to Niagara) in order to meet with colonial officials. Portland advised:

The primary duty of the new appointee is fomenting jealousy which subsists between them and the Six Nations, and of preventing, as far as possible, any junction or good understanding taking place between those two tribes. It appears to me that the best and safest line of Policy to be pursued in the Indian Department is to keep the Indians separate and unconnected with one another, as by this means they will be in proportion more dependent on the King's Government. ${ }^{67}$

Two months later, Portland emphasized:

I must not omit, on this occasion, again to impress you with the necessity of the most zealous and strict attention to every possible means of preventing connections or confederations from taking place between the several Nations, and that the rendering them dependent upon Your Government, and keeping them as

\footnotetext{
${ }^{67}$ Quoted in Johnson, "Mississauga," 237. Emphasis mine.
} 
separate and distinct as possible from each other, should be laid down by you as a system from which, on no account, you should ever depart. ${ }^{68}$

Portland's instructions included keeping Indian stations disconnected from each other, and to keep Indigenous people "fixed on their own particular concerns, and to prevent connections from being formed between them and other Nations," and that decreeing presents needed to be distributed "in such manner ... to produce the most powerful effect on the Indians, and to leave the strongest impressions on their minds, of their dependence on His Majesty's bounty." ${ }^{69}$ Within four months, Russell reported that he had appointed an Indian agent at York and had ordered him "to do everything in his power (without exposing the object of this Policy to Suspicion) to foment any existing Jealousy ... and prevent as far as possible any Junction or good Understanding between ... Tribes.”70 In the meantime, the Upper Canadian government suspended all land purchases. Further, it refused to approve any sale of the Mississauga territories to outside buyers. Over the next few years, settler over-hunting and the destruction of game habitat compromised the Mississaugas' ability to subsist without capital in the new economy. Consequently, Mississauga communities became increasingly dependent on Crown presents, and the political will to resist British exploitation was undermined through such dependence.

By 1805, Joseph Brant had retired as the main spokesman and negotiator for the Six Nations, and the oral memory of the Toronto Purchase had disappeared with dying chiefs. With the Mississaugas living in poverty and their political alliances weakened, the

\footnotetext{
${ }^{68}$ Quoted in Johnson, "Mississauga,” 238. Emphasis mine.

${ }^{69}$ Quoted in Johnson, "Mississauga," 238.

${ }^{70}$ Peter Russell to Duke of Portland, Mar. 21, 1798, in Peter Russell, The Correspondence of the Honourable Peter Russell With allied documents relating to his administration of the government of Upper Canada, during the official term of Lieutenant Governor J.G. Simcoe, while on leave of absence, 3 vols. (Toronto: Ontario Historical Society, 1932), 2: 122-3.
} 
British approached them once more to negotiate a land cession of the Mississauga Tract. At that time, the British presented them with a proper deed, intended to confirm the Toronto Purchase. The boundaries of the deed presented to the Mississaugas placed the boundary of the Toronto Purchase several miles to the west of where the oral record suggested it was, but by that time the Mississaugas were under pressure to rely on the written record of the surveyors from 1788 , rather than their oral memory that had been compromised by poverty and illness. Reluctantly, and in the context of fear that British presents would be discontinued entirely, the Mississaugas of the Credit River ceded the Mississauga tract, and confirmed the 1788 boundaries of the Toronto Purchase. In the end, the Mississaugas of the Credit River ceded 80,000 acres of land to the British in 1805 for 2.5 percent of market value. ${ }^{71}$ The land that was ceded would end up including some of Canada's most expensive homes.

The elimination of Indigenous land title was facilitated through a progressive shift from middle ground to divided ground in the Great Lakes region in the second half of the eighteenth century. The political importance of Indigenous military alliances diminished for the British following the defeat of the French in 1759. After the American Revolutionary War, the British abandoned their treaty promises and military alliances west of the American border, and began building a settler colonial state in what would become Ontario. Loyalist refugees were granted individual title to land that became the basis for the accumulation of settler wealth once immigration intensified, enabling the creation of cities. Indigenous land title was eliminated through provisions in settler colonial law barring Indigenous groups from selling land to any party other than the Crown. Further, Indigenous title was eliminated through unethical land negotiations, such

${ }^{71}$ Johnson, “Mississauga,” 249. 
as those that took place for the region now known as the City of Toronto. Transforming territories shared by many nations into privately owned lots facilitated the establishment of the settler colonial states and cities we know today. In particular, Wychwood Park's history is embedded within the settler colonial system of land exchange. The following section will document the history of land ownership and subdivision in what would become Wychwood Park.

\section{Wychwood Park's History of Subdivision}

Wychwood's history of subdivision began as soon as lots were made available to government officials to entice the move of government from Niagara to York. When the region now referred to as the City of Toronto was first carved up into a symmetrical grid pattern on a surveyor's map, Wychwood Park straddled small corners of two farm lots. The land now known as Wychwood Park was once combined portions of Lot 26 and 27, "Second Concession from the Bay." The history of land subdivision in Wychwood Park is a history of increasing property values in the growing, industrializing City of Toronto.

The patent for Lot 26 was registered on April 21, 1797 to Major David Shank. The patent for Lot 27 was issued on May 26, 1796 to Captain Samuel Smith. Both Major Shank and Captain Smith served in the Queen's Rangers, the regiment responsible for building the urban infrastructure for York/Toronto. In today's terms, both men were granted lots running north-south from Bloor Street to St. Clair Avenue - a distance spanning three subway stops on the Yonge Line. The dimensions of each lot were 6,600 feet north-south, and 1,320 feet east-west. 


\section{Lot 26}

The Honourable George Crookshank, member of the Legislative Council, inherited David Shank's lot on November 16, 1839. In 1850, Crookshank hired John Stoughton Dennis, a land surveyor, to subdivide the lot into at least eleven lots for future settlement. In 1850, Crookshank sold several of those lots for a combined sum of $£ 1,249 .{ }^{72}$ Lot 5 is of particular interest, because portions of it would eventually become Wychwood Park. Lot 5 was sold for $£ 300$ to Edward Rutherford, a merchant living in Toronto, in 1850. Two years later, in 1852, Rutherford sold Lot 5 to Alexander McDonald, a barrister, for $£ 600$, who then sold it two weeks later to the Honorable William Hume Blake, Chancellor of Upper Canada for £600, without turning a profit. Hume Blake kept the property until 1866, when he sold it to his son, future Ontario premier Edward Blake, for $\$ 3,200$. Rupert Mearse Wells, a business partner of Edward Blake's (Wells would become Speaker of the Provincial Parliament in 1873) purchased Lot 5 in 1870 for an undisclosed sum, and one year later sold the lot to William James Shaw, a merchant, for $\$ 2,800$. Figure 3.1, "Plan 332," dates from 1873, the year before Marmaduke Matthews purchased a portion of Lot 5. Plan 332 offers a closer view of Dennis's subdivision, including the lot numbers used when Matthews purchased his property. In 1874, Marmaduke Matthews purchased his portion of Lot 5 for $\$ 4,000$. In twenty-three years, the value of Lot 5 of Dennis's subdivision had appreciated from $£ 300$ to $\$ 4,000 .{ }^{73}$ Given the use of multiple currencies simultaneously in use in the nineteenth century in York, it is difficult to quantify a specific appreciation of land value. Suffice to

\footnotetext{
${ }^{72}$ Lot 7 was sold to Dennis for $£ 285$, Lot 8 was sold for $£ 304.10$, Dennis sold his lot to Philip VanKoughnet, a lawyer and politician, for $£ 380$, reflecting the market rate for farmland.

73 "Township Lots 24 to 33 Concessions 2 and 3 Volume 176 - B," Toronto Land Records Office. Accessed December 2013.
} 
say, within three generations of the initial free grants in the York township, the value of land rose exponentially.

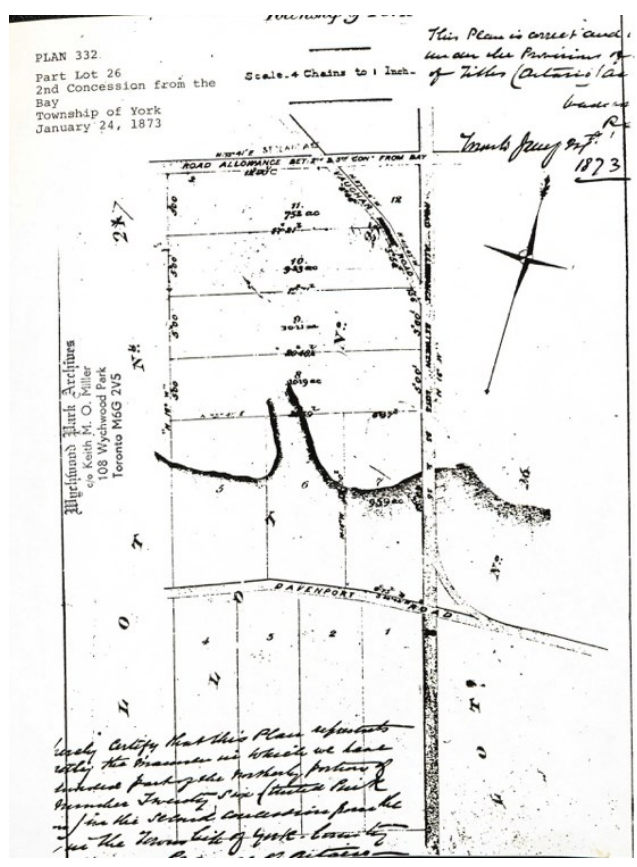

Figure 3.11 Plan 332. From: Keith Miller, History and Development of Wychwood Park.

\section{Lot 27}

Meanwhile, Captain Samuel Smith was granted his 200 acres in 1806 in the neighbouring farm lot. In 1823, Smith sold the entire lot to merchant Peter McDougall for $£ 300$. McDougall hired a surveyor, David Gibson, to draw up plans subdividing the property into six-acre lots, including a road named Christy Street after McDougall's wife, Christy. "Christy" Street would later become registered with the town as Christie Street, now one of midtown Toronto's main north-south thoroughfares. Thomas Bell, a merchant, was granted several of the lots in 1836 as payment for an unspecified debt he was owed. In 1846, Thomas Bell sold two of his lots for an unspecified sum to Adam Wilson, Esquire. Within a week, Wilson sold those lots to Walter McKenzie, Esquire, for 
£359. In 1874, Alexander Jardine purchased the lots for $\$ 4,000$. By 1874 , the community was becoming more and more established as a country neighbourhood, within a day's commute of the city centre. In 1888 Jardine sold land to Alice Sweny for $\$ 25,000$. Three years later, the Swenys, Matthews, Jardines, Hunters, and Thomas Litster partnered and registered Plan 854 with the City of Toronto to subdivide the land further. Three years later, in 1891, those same investors updated Plan 854 as Plan 1092, which contains the first mention of the name "Wychwood Park."

\section{Conclusion}

This chapter has documented the systematic elimination of Indigenous land title and political authority in the Toronto region. I have illustrated how the elimination of Indigenous land title facilitated a settler colonial land economy premised upon Indigenous exclusion and private property rights for settlers. This history places Wychwood Park in a broader context and addresses gaps in existing literature that assert Wychwood Park's history began in 1888 when land was purchased by Marmaduke Matthews.

Indigenous elimination was the basis for the establishment of Wychwood Park. After negotiating land cessions under questionable circumstances, the British colonial government granted the land upon which Wychwood Park would be built for free to military officers. The lots granted were a day's commute from the town of York, on land that did not appreciate in value until the City of Toronto expanded northward, enabling landholders in the region to subdivide their land for a profit.

Settler communities became identified with the land; individual settlers and their families could name land, labour on the land, and establish a shared sense of belonging 
within the colonial landscape. It is perhaps because of the cultural identification of land with its owner in Toronto that Wychwood Park is publicly remembered as the brainchild of Marmaduke Matthews, as opposed to being remembered as a tract of farmland subdivided many times over the nineteenth century until being annexed to the City of Toronto in 1909. In the next chapter, I will examine the landscape and architectural design of the Park, arguing that the aestheticization of territory is one way that settlers indigenize themselves to colonial territory, thereby naturalizing their presence within it. Settler indigenization intensifies Indigenous elimination to the extent that it creates a cultural system premised upon the denial of Indigenous legitimacy. While settler indigenization overlaps with Indigenous elimination in order to produce settler colonial society, Chapter Four will focus specifically on settler indigenization and how it can serve as a lens for understanding and interpreting the design features of the Wychwood Park neighbourhood. 


\section{Chapter Four \\ Settler Indigenization: The Aestheticization of Appropriated Territories in Art, Architecture, and Landscape Design}

Settler identities are also forged in relationship to land: it is the location and basis for security, opportunity, and identity as a new people.

Emma Battell Lowman and Adam Barker ${ }^{1}$

Landscapes provide a purchase on social/cultural/political/economic questions that are unobtainable through other analytic means because questions work through the landscape.

\section{Richard Schein ${ }^{2}$}

The impact of settler colonialism is starkly visible in the landscapes it produces: the symmetrically surveyed divisions of land; fences, roads, power lines, dams and mines ... Land and the organized space on it, in other words, narrate the stories of colonization.

Tracey Banivanua Mar and Penelope Edmonds ${ }^{3}$

The previous chapter situated Wychwood Park within the settler colonial process of Indigenous elimination. This chapter places Wychwood Park within the settler colonial process of settler indigenization. Settler indigenization is the process whereby settler colonial society asserts its own culture of belonging in occupied territory. According to Battell Lowman and Barker, settler indigenization's goal is to establish a society that understands itself to be culturally dominant and authentically situated.

\footnotetext{
${ }^{1}$ Emma Battell Lowman and Adam J. Barker, Settler Identity and Colonialism in 21st Century Canada (Halifax: Fernwood, 2015), 53.

${ }^{2}$ Richard Schein, “A Methodological Framework for Interpreting Ordinary Landscapes: Lexington, Kentucky's Courthouse Square,” Geographical Review 99, no. 3 (2009), 381.

3 Tracey Banivanua Mar and Penelope Edmonds, eds., Making Settler Colonial Space: Perspectives on Race, Place, and Identity (London: Palgrave Macmillan, 2010), 2.
} 
Lorenzo Veracini has argued, "Migrants, by definition, move to another country and lead diasporic lives, settlers, on the contrary, move ... to their country." ${ }^{, 4}$ When settlers indigenize themselves to a place, they effectively claim that space as always already belonging to them. Settler indigenization can involve the disavowal of Indigenous history and land claim, as well as the cultural preoccupation with settler origin stories and land use traditions.

This chapter focuses specifically on how the aestheticization of space - the process of creating a landscape out of land - produces settler colonial belonging. As W.J.T. Mitchell has argued, a landscape is a "cultural medium [that]... naturalizes a cultural and social construction, representing an artificial world as if it were simply given and inevitable." In this chapter I argue that Wychwood Park's landscape functions to indigenize settler colonial society to appropriated territory by transforming Indigenous territory into distinctly British space. By landscaping, I am referring to the construction of a settler colonial gaze formalized through art and aesthetic ideas that visually coded appropriated territory into the property of the settler colonial project "as if it were simply given and inevitable."

Today, the design of Wychwood Park is lauded not only as distinctly British, but as a reflection of settler genius. Marmaduke Matthews is credited with establishing the Park. George A. Reid is celebrated as the visionary behind its landscape aesthetic. The iconic architecture is attributed to Eden Smith. In this way, the landscape and architectural design of Wychwood Park communicate not only that the space belongs to settler culture, but that settler culture created it. The notion that the land is not only

\footnotetext{
${ }^{4}$ Lorenzo Veracini, Settler Colonialism: A Theoretical Overview (London: Palgrave MacMillan, 2010), 3.

${ }^{5}$ W.J.T. Mitchell, ed., Landscape and Power (Chicago: University of Chicago Press, 1994), 2.
} 
owned but created by settler colonial society reinforces landscape and architectural design as a tool of settler indigenization. In particular, when settler colonial social systems modify the land, the land becomes effectively de-territorialized of Indigenous meaning, and re-territorialized as settler colonial. ${ }^{6}$ The process of de-territorializing and reterritorializing serves settler colonial interests - symbolic, cultural, economic, and political.

\section{Colonial Geographies}

As the opening quotation from Tracey Banivanua Mar and Penelope Edmonds attests, "land and the organized space on it ... narrate the stories of colonization." Early settler colonial land policies in Upper Canada stated that permanent land title would be granted once settlers demonstrated their ability to "improve" the land, such as building a fence or clearing the public roadway that ran alongside their property. ${ }^{7}$ Surveyors drew property lines, but settlers were responsible for shaping the landscape to build settler society. The labour of settlement continues to demand the transformation of the landscape. Very little is known about the pre-colonial history of the land now referred to as Wychwood Park. However, the ways in which the land was physically shaped to create the Park have been well documented.

There is little written information about the cultural significance of the area now known as Wychwood Park prior to British settlement. However, the Park straddles two significant environmental systems that have been of economic (if not also cultural and

\footnotetext{
${ }^{6}$ Here, the language of de-territorialization and re-territorialization are borrowed from Graham Livesay's interesting work on gardening labour as re-territorializing. See Graham Livesay, "Assemblage Theory, Gardens and the Legacy of the Early Garden City Movement," Arq: Architectural Research Quarterly 15, no. 3 (2011): 272.

${ }^{7}$ Lillian Gates, Land Policies of Upper Canada (Toronto: University of Toronto Press, 1968), 27.
} 
political) importance to Indigenous communities since time immemorial: Davenport Road and Taddle Creek.

The southern boundary of the Park abuts what is now known as Davenport Road (see Figure 4.1). Davenport Road follows the trail of a centuries-old footpath that used to connect the Humber River to the Don River, as part of the Toronto Carrying Place portage route. The footpath linked settlements to hunting and fishing grounds. The footpath linked the Toronto region to trade networks extending to the Upper Great Lakes and Western Plains to the west, and the Atlantic Coast to the east. ${ }^{8}$ The earliest British maps in the region clearly demonstrate knowledge of this longstanding transit route connecting Toronto to the world around it. ${ }^{9}$ The map in Figure 4.1 was created in 1793 the same year the British established Fort York and began encouraging settlement to form the Town of York. The trail now known as Davenport Road is highlighted near the top of the map.

\footnotetext{
8 “Davenport Road," Heritage Toronto, http://heritagetoronto.org/davenport-road/. Accessed October 25, 2017 (no longer available).

9 “The Davenport Trail," Heritage Toronto, http://heritagetoronto.org/the-davenport-trail/. Accessed October 25, 2017 (no longer available).
} 


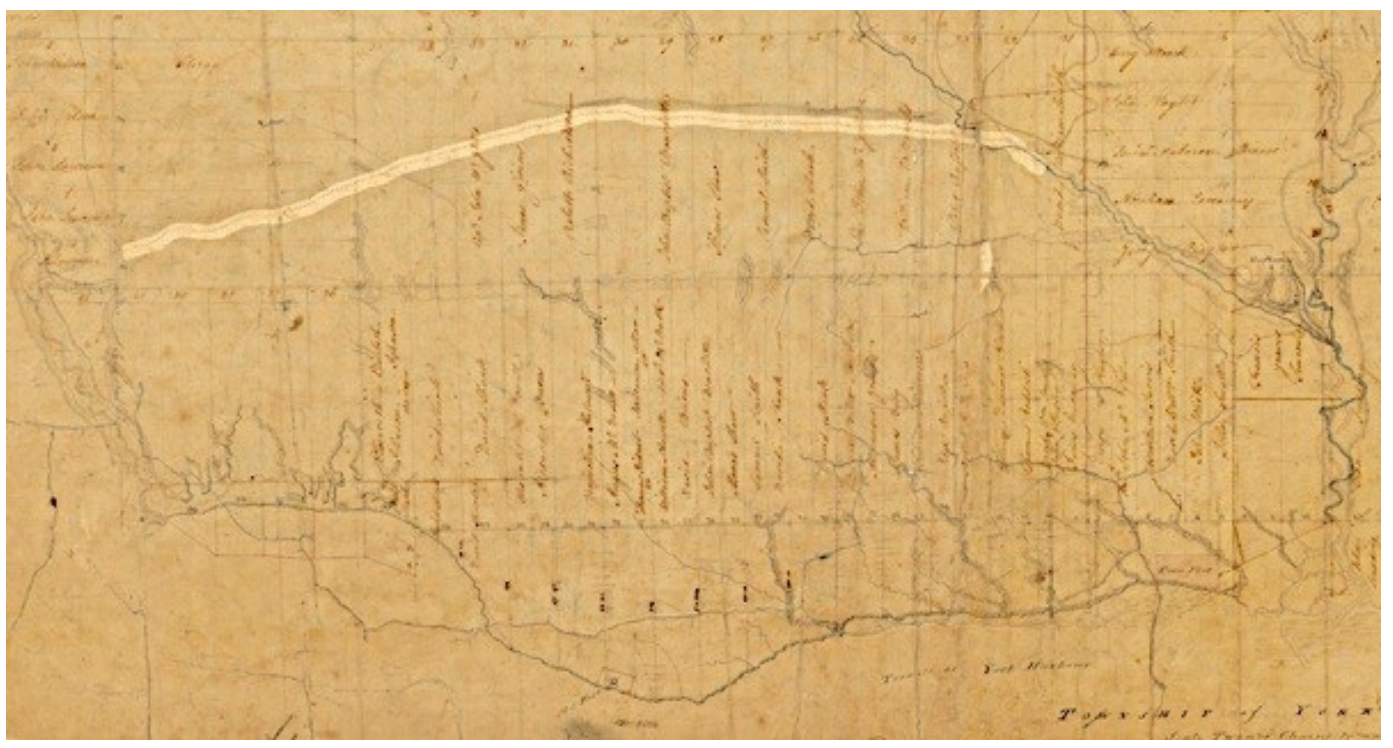

Figure 4.12 Survey of the Township of York by Alexander Aiken around 1793. The Davenport Trail is highlighted across the top of the image. http://heritagetoronto.org/thedavenport-trail/

Davenport Road is one of Toronto's only east-west thoroughfares that meanders, rather than following a straight surveyor's line. In the early nineteenth century, the established trail was named "Davenport Road" after "Davenport," the name of John McGill's house. McGill was a captain with the Queen's Rangers who had been a prisoner of war alongside Lieutenant Governor John Graves Simcoe during the American Revolutionary War. McGill's "Davenport" (1797-1913) was the first house built by a British land grantee in the area. The re-naming of an ancient footpath after a settler's house is a reminder of Murphyao and Black's argument that settlers use place names to invoke their sense of belonging in colonial territory. ${ }^{10}$

Wychwood Pond is the second significant environmental system that pre-dates colonial settlement in Wychwood Park. Wychwood Pond is the only place in Toronto where Taddle Creek is visible above the earth's surface. Taddle Creek was an important

\footnotetext{
${ }^{10}$ Amanda Murphyao and Kelly Black, "Unsettling Settler Belonging: (Re)naming and Territory Making in the Pacific Northwest," American Review of Canadian Studies 45 (2015): 315-31.
} 
waterway in Toronto, a trout and salmon-bearing stream ${ }^{11}$ that began at Wychwood and emptied into Lake Ontario near what is now Parliament and Front streets.

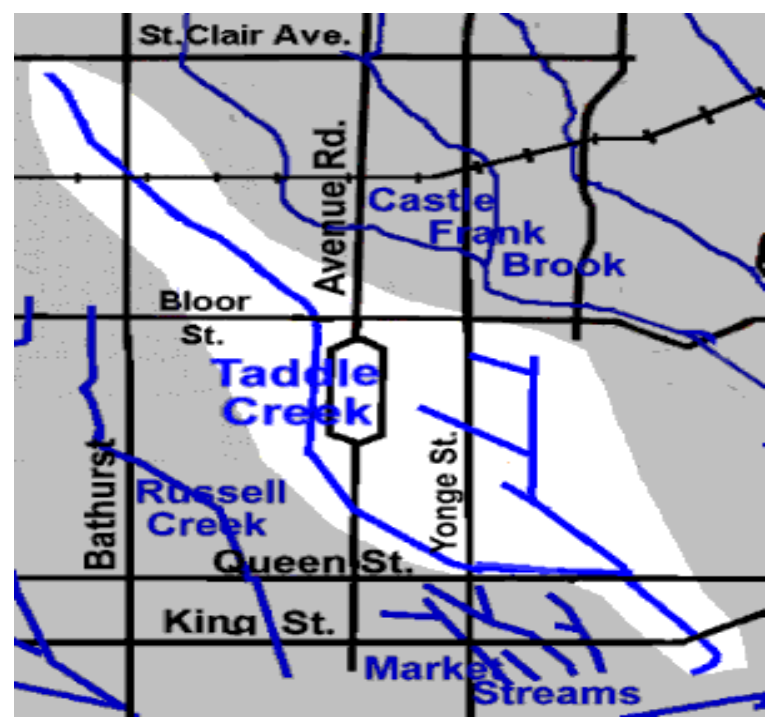

Figure 4.13 Map of the Taddle Creek Course. http://lostrivers.ca/content/taddlekey.html

Taddle Creek was important enough as a fishing site that continued access to the creek was negotiated by the Mississaugas of the Credit River during land negotiations in 1805. ${ }^{12}$ The stream had been a food source since time immemorial, and became progressively polluted throughout the nineteenth century, when it was eventually diverted underground into the sewer system as a public health measure. The creek was dammed in Wychwood Park in the 1870 s, creating a pond to be used as an ice source in the winter

\footnotetext{
${ }^{11}$ Ian Coutts, "Lost Rivers: Storm Sewers Swallowed Many of the Streams and Brooks that Once Meandered through Our Cities. Now, a New Movement Is Aiming to 'Daylight' those Forgotten Watercourses," Canadian Geographic 122, no. 3 (May 2002), 64.

${ }^{12}$ Rodney Bobiwash, "The History of Native People in the Toronto Area," in The Meeting Place: Aboriginal Life in Toronto, ed. Frances Sanderson and Heather Howard-Bobiwash (Toronto: Native Canadian Centre of Toronto, 1997), 15.
} 
months. ${ }^{13}$ Figure 4.3 is a photograph of men cutting ice from the pond during winter months in 1910.

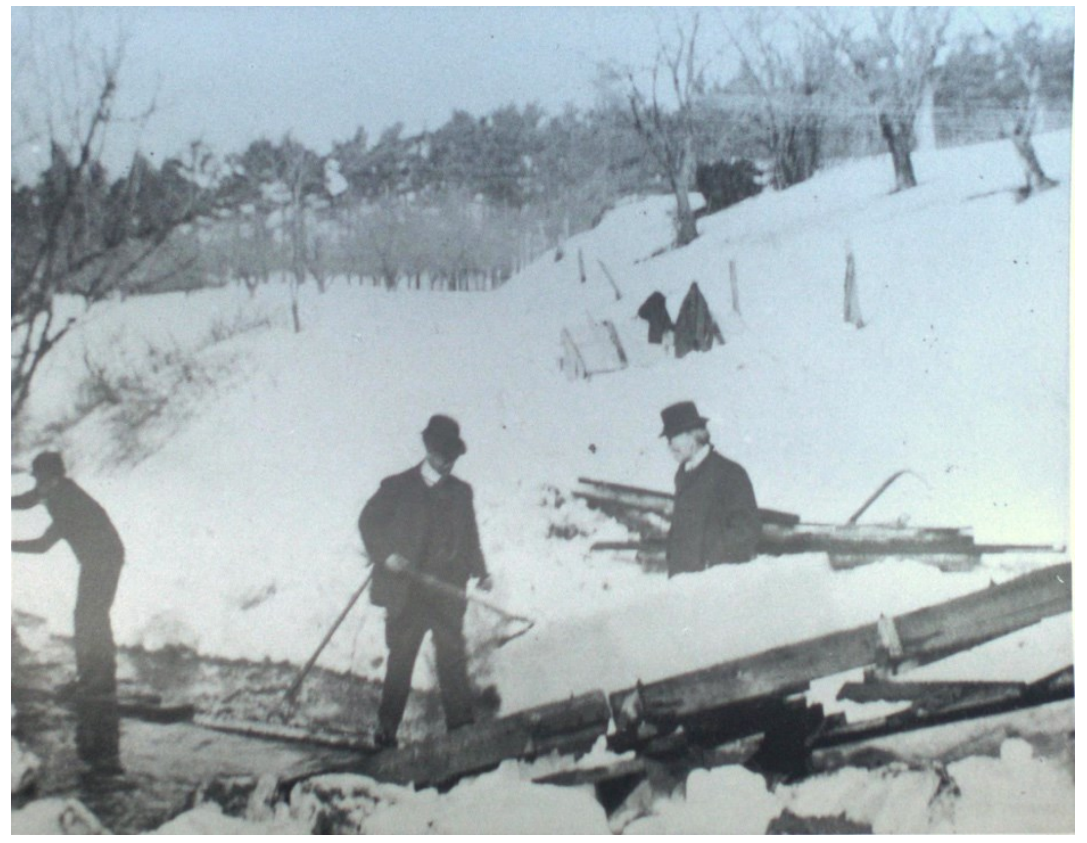

Figure 4.14 Cutting ice on Wychwood Pond, 1910. Toronto City Archives.

Urban growth and industrialized water systems form part of Wychwood Park's colonial story. Permanent settlements in the Park shifted the landscape and dammed the creek in order to provide an ice source. Industrialized water management drove the creek underground, and in its place, an entirely new way of knowing Taddle Creek emerged, to be called Wychwood Pond. The pond is now commonly known as a beautiful feature of Wychwood Park. While understood as a place that sustains wildlife, the Pond is no longer a source of food for human communities nor does it serve as a stream that could lead a traveller to Lake Ontario. The development of Wychwood Park involved significant changes to the physical environment that transformed the territory in the interests of

\footnotetext{
${ }^{13}$ Sophia Attwells, "Taddle Creek," Turtle Island Conservation, http://turtleislandconservation.info/tolayers.asp?pg=2\&id=916\&xcommunity=Toronto. Accessed October 25, 2017 (no longer available).
} 
sustaining settler colonial society. Consequently, the area now known as Wychwood Park took on new meaning within a cultural system designed to assimilate settlers into a national imaginary that saw Canada's history as noticeably British.

\section{Wychwood Park and Settler Colonial Place-Making}

Wychwood Park is characterized in local press as a unique neighbourhood that offers an idealized environment, and invokes a fantastical sense of British history. I have already cited instances where the Park's environment is celebrated as an "oasis"14 and a "leafy eden," "15 a place that invokes "old country nostalgia in this bit of Oxfordshire in the colonial wilds." ${ }^{16}$ Its so-called founder, Marmaduke Matthews, is cast in popular narratives as having had a "pioneering vision" when he subdivided the land to sell lots to artists, ${ }^{17}$ and a National Post journalist suggested the Park compels visitors to "sit comfortably under an oak tree in the traffic-free bliss that is Wychwood Park and imagine ... warm beer and cricket and spinsters cycling to church in the watery lunchtime sun. Such is the English garden estate feel of this tiny-perfect corner of Toronto."18

In his study of landscape and power, John Wylie argues that "A landscape is thus not just the land itself, but the land as seen from a particular point of view or perspective ... landscape takes shape within the realms of human perception and imagination." 19 The discourses I have cited above are important reminders that Wychwood Park's landscape is

\footnotetext{
14 "Wychwood Park: An Oasis of Green Among the Asphalt," Canada Home Décor (Summer 1979): 56.

${ }^{15}$ William Morris Society of Canada Newsletter, Winter 1991-2, 5.

${ }^{16}$ Leon Whiteson, "Wychwood Park: A Tranquil Retreat for a Metro Elite," Toronto Star, January 16, 1982.

${ }^{17}$ Andre Ramshaw, "Best of TO: Forever an England in a Tiny Corner of the West End," National Post, n.d. City of Toronto Archives Wychwood Park fonds.

18 Andre Ramshaw, "Best of TO."

${ }^{19}$ Wylie, Landscape, 7.
} 
located in the physical and the imaginative realms. The physical landscaping has shaped trees and gardens, but the imaginative world this landscaping invokes is consistently historical and English. In this way, the landscaping of Wychwood Park recodes Toronto as located within England's past. These discourses that map Wychwood Park as a historically English space - like the heritage plaque at the Park's gates that remind visitors that Wychwood was named after a forest in Oxfordshire - are evidence of a successful process of settler indigenization that has taken place within one of Toronto's most famous garden suburbs.

Wychwood Park's aesthetic is celebrated for achieving the illusion of medieval England in midtown Toronto. The Park is rendered culturally meaningful by the way its physical environment appears simultaneously edenic and English. In this way, Wychwood Park can be read as a site wherein British colonial occupation is successfully naturalized through aesthetic means. The Indigenous history of the region is rendered irrelevant to the Park's cultural importance, to the extent that it was never mentioned in the Toronto Historical Board's heritage district conservation study, written in $1983 .{ }^{20}$

The omission of Indigenous history from the history of Wychwood Park speaks to Blomley's argument that cities are spaces of "organized forgetting". To be sure, when Wychwood Park residents designed their neighbourhood in the style of English gardens and Arts and Crafts architecture, they did so without mention or apparent awareness that they were occupying Indigenous territory. Instead, the Park was approached as if it were terra nullius - empty land belonging to no one. By landscaping the Park and creating the Wychwood neighbourhood, founding residents acted as though they made something out

\footnotetext{
${ }^{20}$ The study is a component part of the broader Wychwood Park Heritage Conservation District Plan (Toronto: Toronto Historical Board, 1986).
} 
of nothing. Similarly, heritage-minded late twentieth-century residents constructed the story of the Park's founding as beginning within the geographic imagination of Marmaduke Matthews, including offering a linguistic history of the word 'Wychwood'. The late twentieth century narrative of Wychwood Park denies that Toronto had any Indigenous history - or present - at all. The apparent irrelevance of Indigenous life or land title reinforces the nineteenth century colonial myth of the 'vanishing Indian' destined to disappear.

In what follows, I will document the ways in which Wychwood residents worked to re-territorialize Wychwood Park as an English garden suburb. I will offer an account of the development of Wychwood Park, and how the architectural style incorporated key elements from the British Arts and Crafts Movement. By deliberately shaping the Park to embody a garden aesthetic, Wychwood residents changed the symbolic meaning of the Park. Similarly, the presence of Arts and Crafts homes located the Park as a site invoking British cultural referents, thereby naturalizing English cultural authority in Toronto.

\section{Wychwood Park History: Arrival of the Artists}

As soon as artists began moving into the Park in 1906, the physical landscape was modified in order to build according to the registered plan of subdivision. The first lot in Wychwood Park was sold to artist George A. Reid. Reid purchased a lot at the north end of the Park, where his Upland Cottage was built, a home with studio space that he designed. Reid's arrival in Wychwood Park was part of a wave of new lot purchases by artists who had all been close neighbours in what is today Toronto's west end, near High Park. Muralist Gustav Hahn, architect Eden Smith, and design manager George Howell 
had all been living in the west end, in houses they designed, when they decided to follow Reid's lead in moving to Wychwood Park within the same eight-year period, from 1906$1913 .^{21}$

Reid was Vice President of the Wychwood Corporation from 1908 to 1916 and was involved in major projects to develop the Park, in accordance with the plan of subdivision registered with the Township of York in 1891. In order to operationalize the registered design, the Wychwood Corporation physically moved a cluster of houses at the northern end of the Park several yards south to make room for further lots. The excavation of houses took place from 1908-1911. Prior to being moved, the houses had been fronting onto Alcina Avenue. ${ }^{22}$ Figure 4.4 is the only known photograph of the house-moving process.

${ }^{21}$ There are minor inconsistencies in how the migration from the west end to Wychwood is dated. The Heritage Conservation District Plan dates George Reid's arrival to the Park from 1906, whereas the Artists, Architects, \& Artisans catalogue dates his arrival from 1908. A possible explanation for this discrepancy is that the District Plan may be naming the date of land purchase, whereas the AAA catalogue dates George Reid's arrival from the time he began physically living in the house he designed, which would have taken some time to build.

${ }^{22}$ Significantly, Alcina Avenue had been previously referred to as "Batoche Street" in the mid-1880s, presumably to memorialize the imperial military victory against the Metis in Saskatchewan. Land records show that in 1888 a neighbouring lot to Wychwood Park was purchased by Louis Ovila Philadelphia Genereux, "and his wife, Alcina Elizabeth." The change in street name could be interpreted to reflect a change in land ownership in the late 1880s. 


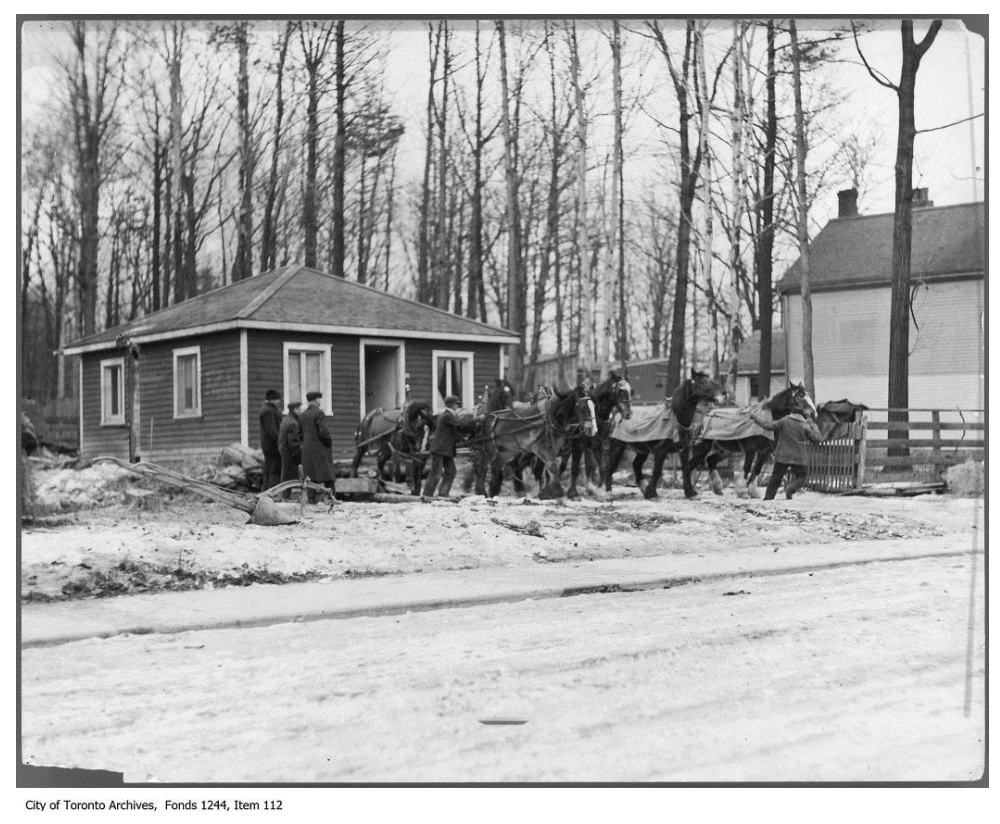

Figure 15.4 Moving a house in Wychwood Park 1910. Toronto Municipal Archives.

The displaced earth from the excavation of houses was then used to support the construction of an earthen roadway/bridge over the Taddle Creek ravine. George Reid supervised much of this construction. His oversight included supervising the sale of Alcina Avenue properties, the development of nearby Bracondale Avenue, the construction of a bridge for the Walker and Wrinch properties, and interpreting a plan for taxation for the Park. ${ }^{23}$ These tasks reorganized the landscape of Wychwood Park including its governance structure - designed to sustain the settler presence in the area.

In 1908, when Gustav Hahn purchased a lot at Wychwood, the terms of the land trust agreement had been changed since Reid's 1906 arrival. The terms of Hahn's purchase agreement included additional rules, such as, "No cow-shed, pig-pen, or chicken coop shall be erected or maintained upon the said premises. All plans for building must be submitted to the Wychwood Corporation and its approval obtained before the erection of

\footnotetext{
${ }^{23}$ Memoranda for Mr. Henderson by Mr. Reid re Wychwood Park Trustees Account. City of Toronto Archives, Keith Miller Fonds, Box 155149, File 181.
} 
the same commenced. The exact location of every building shall be submitted to the Wychwood Corporation and the Wychwood Corporation's approval obtained to the site before the building is commenced." ${ }^{24}$ The Wychwood Corporation stipulated that it wanted to approve any "alteration in the surface of the soil," and that if terracing or grading was to be approved, the corporation would then determine where the soil would be deposited at the purchaser's expense. In addition to forbidding any farming, the deed also stipulates that no "sanitarium, hospital, hotel, saloon, or boarding house" shall be built on Wychwood Park property. New fencing required approval by the corporation, as "unsightly" fencing was banned.

These changes to building guidelines are significant, and served as building bylaws before the City of Toronto began developing them. Building bylaws serve to standardize design features in a particular area. By instituting proto-bylaws in the area, Wychwood residents prioritized design cohesiveness from an early stage of the Park's development. The land trust, which gave trustees political authority over residential design, was instrumental in ensuring the land could be developed with aesthetic standards in mind. In this way, the land was reshaped deliberately in order to convey a set of values that reflected the residents who called the Park home. This process de-territorialized the Park of its former meaning, and re-territorialized it as an aestheticized English garden suburb.

Reid was not the only artist taking leadership roles in Wychwood Park's development. In the first decade of the twentieth century, Eden Smith and his apprenticing sons were establishing a growing architectural practice that would become famous for uptown residential design. They would end up designing the majority of

\footnotetext{
${ }^{24}$ Agreement of Sale Between the Wychwood Corporation and Gustav Hahn. Toronto City Archives, Keith Miller Fonds, Box 155132, File 7.
} 
houses built in Wychwood Park prior to 1920. The Park's governance structure encouraged collective decision-making when it came to building new houses or making significant changes to the landscape design. The move of artists from the city's west end to Wychwood Park in the early twentieth century ensured that like-minded, trained artistic workers were participating in the governance model established two decades before their arrival. The result was a collectively owned subdivision designed by artists, whose influence would continue to give Wychwood Park a reputation for beautiful design.

\section{Garden Suburbs and the Arts and Crafts Movement}

Aesthetically, Wychwood Park stands as an example of a Canadian planned garden suburb, featuring Arts and Crafts architecture. Both garden suburb design and Arts and Crafts architecture were popular in the early twentieth century, and reflected aesthetic reactions against industrialized Victorian society. In other words, both aesthetic movements were grounded in English space.

Garden suburbs were planned residential communities that grew out of the larger Garden City movement, a vision for urban planning that imagined designing communities in such a way that would put "townscape subservient to landscape. ${ }^{, 25}$ Frustrated by the pollution of industrialized urban environments, Garden City proponents argued that built environments should complement nature, and integrate into it. Generally speaking, garden suburbs are planned communities with low residential density, containing ample green space and landscaped gardens and terraces. Typically, winding roads are favoured over

\footnotetext{
${ }^{25}$ Edward Hubbard and Michael Shippobottom, A Guide to Port Sunlight Village (Liverpool: Liverpool University Press), 5.
} 
grid-patterned streets, and houses are designed to architecturally complement both the landscape and each other.

Similarly, Arts and Crafts Movement leaders like John Ruskin and William Morris argued that nature contained a kind of idealized beauty that art and architecture should emulate. To live in concert with nature in a landscaped environment, then, was a model of residential life that was promoted by Arts and Crafts advocates. Wychwood Park's oversized lots, abundant green space, common parkland, and functional decoration offered a vision for residential living that served as a refreshing counterpoint to downtown crowded neighbourhoods.

The Arts and Crafts Movement grew out of many contemporaneous social and aesthetic movements, one of which was nineteenth-century medievalism, fuelled by an interest in reviving Gothic architecture in Victorian England. Gothic revivalists argued medieval society was ethically superior to Victorian society, because it lacked industrial working conditions. Gothic arches are a nod towards the medieval influence in Arts and Crafts architecture, as are the asymmetrical floorplans, which distinguished Arts and Crafts architecture from standard Georgian models of domestic design. Ruskin advocated for Gothic features in buildings, and promoted the notion that medieval architecture is an example of buildings made by happy workers. He promoted designs that included naturalistic motifs and hand-made ornamentation in buildings, rather than mass-produced decorations. Specifically, pointed arches, handcrafted ornamentation, purpose-built design, asymmetrical floorplans, and an emphasis on local materials all combined to become emblematic of the Arts and Crafts style. These features would end up being applied in diverse ways by architects to various building projects across the world. Not 
only did the flexibility of design possibilities render the Arts and Crafts movement loosely organized, but the commitment to the use of local materials enabled Arts and Crafts ideas to be applied in areas like Canada, where colonials were able to make reference to British tradition while also incorporating a sense of local distinction.

Design principles from both the Garden City movement and the Arts and Crafts Movement are reflected in the Park.

\section{George Reid's Upland Cottage}

The third house to be built in the Park, following Marmaduke Matthews's and Alexander Jardine's original two homes, was George and Mary Hiester Reid's Upland

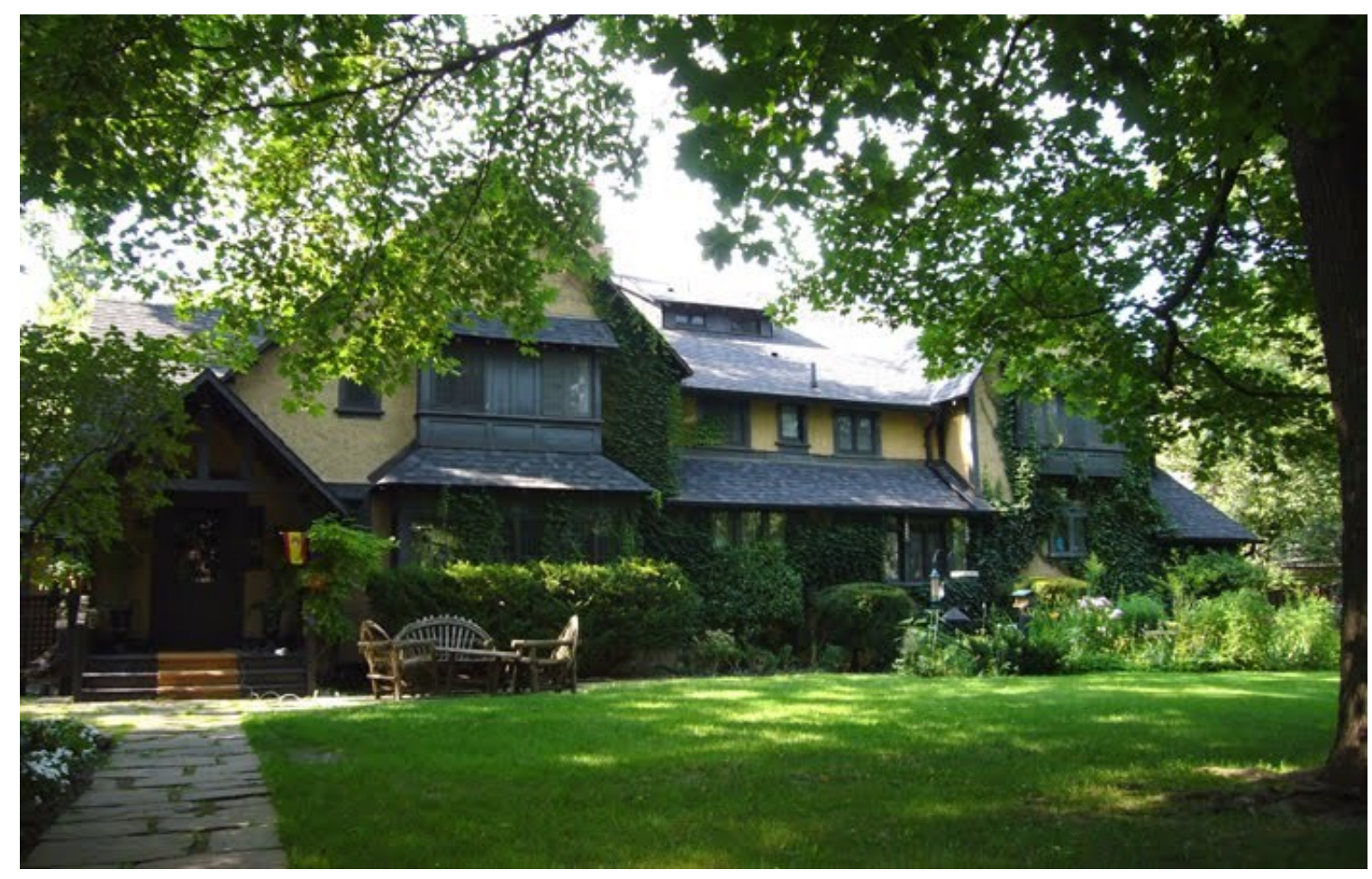

Figure 4.16 Upland Cottage. http://occasionaltoronto.blogspot.ca/2010/07/ 
Cottage. George Reid designed Upland Cottage himself, with the intention of using it as both residence and studio for the artist-couple. Key features of Upland Cottage were its inglenook, musicians' gallery, and decorative murals. The home was built with a wood and stucco exterior, with differently-sized gabled roofs and wooden shingles, emphasizing asymmetry. The front garden was intended to be a Shakespearean garden, and stood in front of an arched doorway into the house. Inside, each artist had their own studio, which was an innovation on the houses in which they had previously lived. ${ }^{26}$ Reid designed a two-storey studio with a gallery on the second floor - a feature of the houses Reid designed at his summertime artist retreat community Onteora, as well as the house they previously lived in on Indian Road. ${ }^{27}$ The inglenook was well represented in images of the Reids' house and artistic production, including a photograph from Toronto Sunday World that profiled Mary Hiester Reid (Figure 4.6) ${ }^{28}$ Exposed beams in the dining room were a standard feature of Arts and Crafts interiors.

\footnotetext{
${ }^{26}$ Christine Boyanoski, “Artists, Architects \& Artisans At Home,” in Artists, Architects, \& Artisans: Canadian Art 1890-1918, ed. Charles Hill (Ottawa: National Gallery of Canada, 2013), 99

${ }^{27}$ Boyanoski, "Artists, Architects, \& Artisans," 99

28 "In the Studios of Toronto’s Best Known Artists," Toronto Sunday World, April 2, 1911.
} 


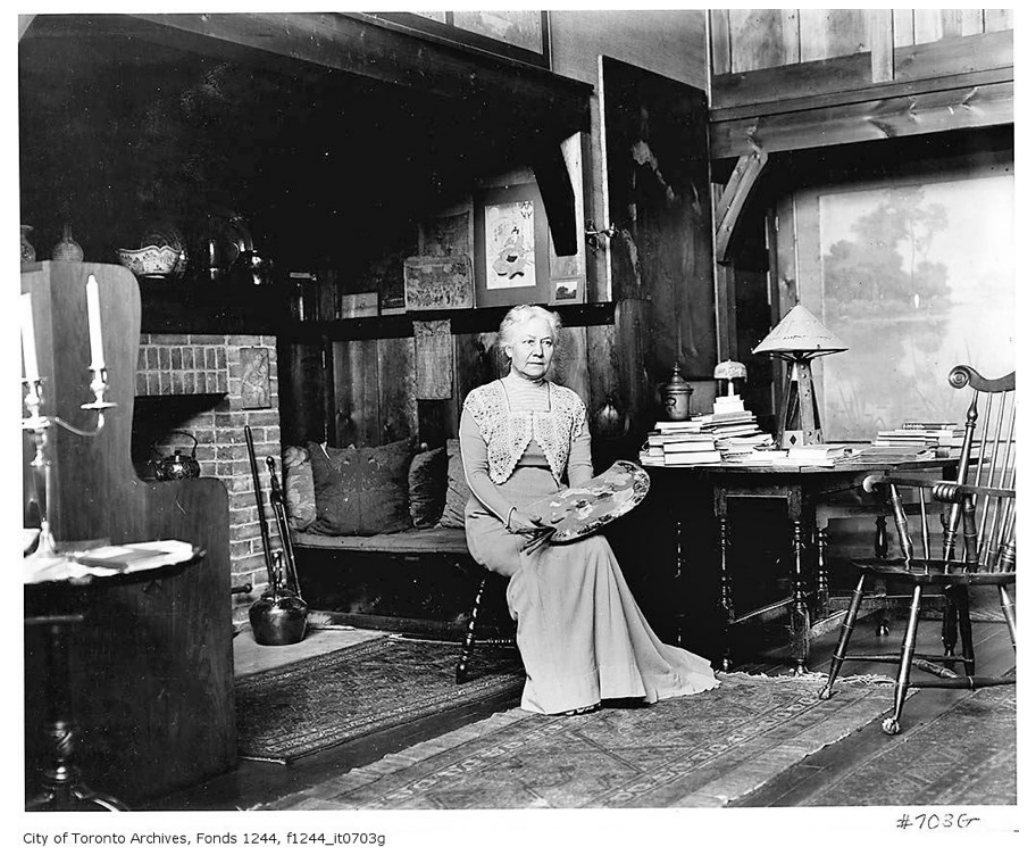

Figure 4.17 Mary Hiester Reid inside Upland Cottage, 1911. Toronto City Archives.

Upland Cottage was profiled in many biographical sketches of the couple while they were living in it, and continues to be featured in publications such as Toronto Life. It is one of the most iconic houses in the Park. Its large, asymmetrical shape sits in harmony with its natural surroundings, like many of the neighbouring houses, creating the aesthetic that has made Wychwood Park famous.

\section{Eden Smith and Wychwood Park}

While Upland Cottage is perhaps the most famous home in Wychwood Park, architect Eden Smith is often credited with Wychwood's unique aesthetic, because most of the Arts and Crafts homes in the Park were designed by his firm between 1906 and 1919. Eden Smith moved to Wychwood Park in 1906, and designed his own home, in 
addition to nine out of nineteen homes built within a decade of his arrival. ${ }^{29}$ He had also designed many of the west-end homes that his artist-friends sold in order to move to Wychwood. In Toronto's west end, Smith had designed houses for Gustav Hahn, and Hahn's brother Paul, as well as his own home. ${ }^{30}$ Once at Wychwood, Smith's firm designed homes for himself, Ralph Eden Smith, Harry Eden Smith, George Howell, E.A. Duvernet, and Mary Wrinch (later Mary Wrinch Reid), among other less notable neighbours. The homes built in Wychwood Park were built during the height of Smith's career as a residential architect for upscale Torontonians. Between 1891 and1925, Smith's firm designed 270 buildings in Toronto, many of them private residences. ${ }^{31}$ Smith's houses became iconic for their steeply-pitched shingled roofs, tall chimneys, and bands of small paned windows, which served as nods to Gothic revivalism. Informed by an English sense of garden, Smith's most notable contribution to Toronto's domestic architecture was a modification to conventional urban home design by positioning the front door at a ninety-degree angle to the street, often placing the kitchen at the front of the house to allow a garden view in the parlour or living room.

The house he designed for himself at 5 Wychwood Park is an example of just such a design, with a side entrance displayed on the left.

\footnotetext{
${ }^{29}$ Wychwood Park Heritage Conservation District Plan, 42.

${ }^{30}$ Douglas Brown, Toronto Architect Eden Smith: Toronto's Arts and Crafts Architect (self-pub., Mississauga, 2003), 42.

${ }^{31}$ Brown, Toronto's Arts and Crafts Architect, 30.
} 


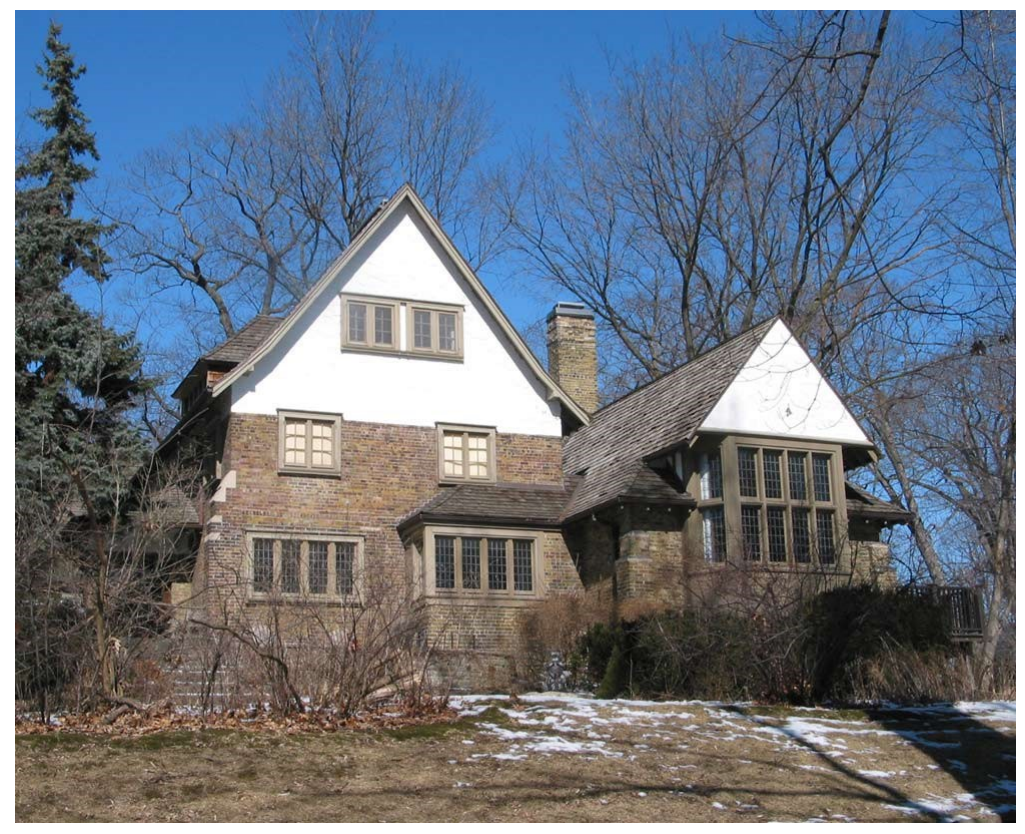

Figure 4.18 Eden Smith's former home at 5 Wychwood Park. Photo by Bob Krawczyk, used courtesy of the Architectural Conservancy Ontario.

https://torontoist.com/2017/07/historicist-eden-smith-arrival-arts-crafts-movement-toronto/

The asymmetry of the building embodies the Gothic principles behind its design, which in this part of Canada can also be read as a rejection of Georgian domestic architecture. The roughcast gables were inspired by George Reid's neighbouring Upland Cottage. Another example of an Eden Smith house in Wychwood Park is number 7, originally owned by George Howell, placed unusually close to the street but echoing some of the popular features mentioned before, such as its steep gable. The placement of the house next to clusters of trees, as well as the landscaping in front, suggests a deliberate intent to place the house within its natural surroundings. 


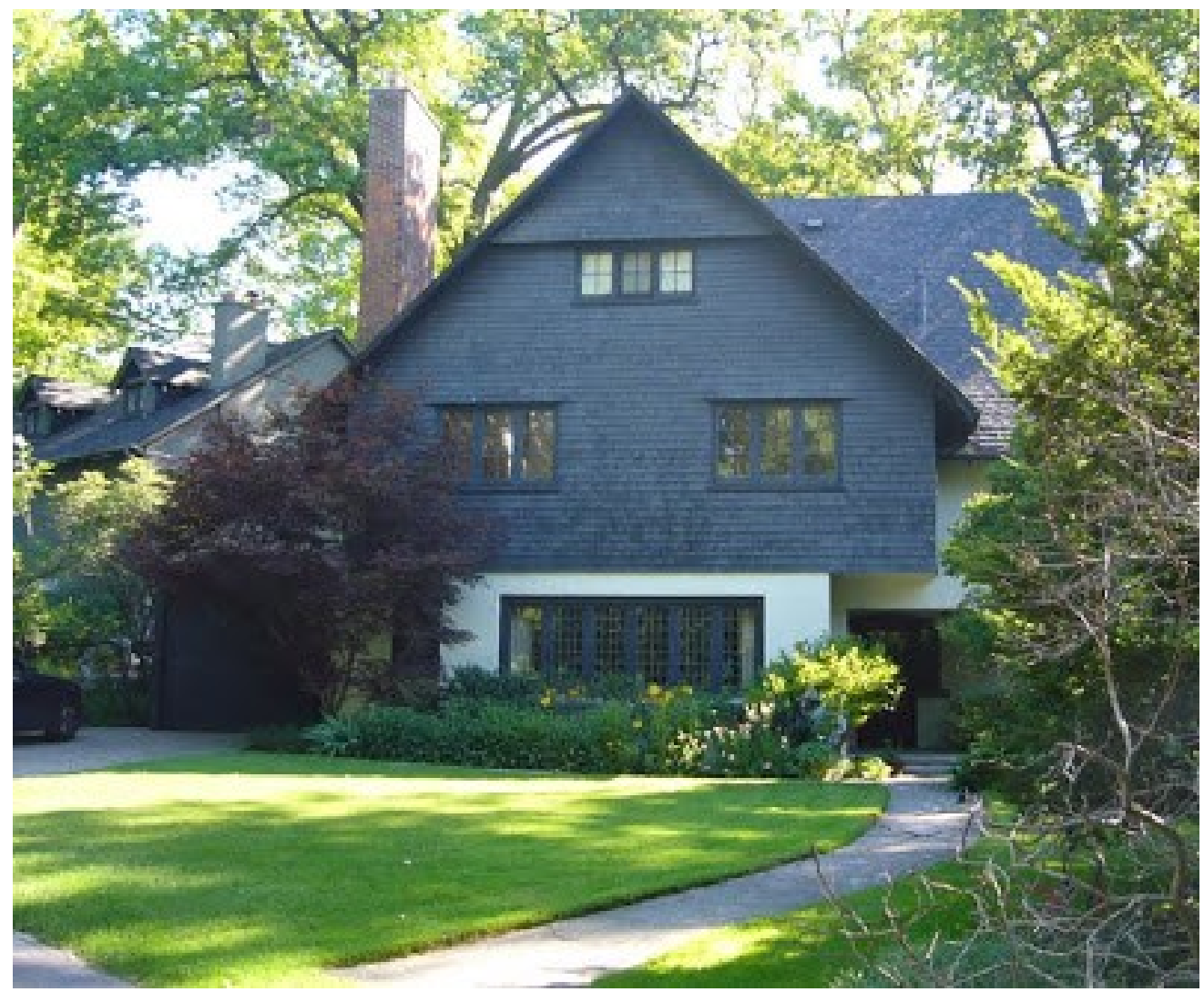

Figure 4.19 7 Wychwood Park, designed by Eden Smith for George Howell in 1910. Neighbourhood Guide: Toronto and the GTA. https://www.neighbourhoodguide.com/toronto/midtown/wychwood-park

The houses built between 1906 and 1919 harmonize with the lush landscape of the Park. Houses sit on irregular lots, often partially obscured by overgrown trees and ferns. This aesthetic distinguishes Wychwood Park from other residential neighbourhoods in Toronto, which feature standardized lot sizes and a high density of residential building. The incorporation of domestic architecture into the landscape is a design feature that reflects Arts and Crafts principles. The houses were designed to integrate into the gardens and trees, complementing the landscape and living in harmony with it.

In this way, Wychwood Park's design was built in opposition to models of urban residential community found in the city centre. These features also contribute to English 
architectural styles blending in seamlessly into Canadian territory, representing part of the re-territorialization process of settler colonial place-making.

At the turn of the twentieth century, social reform campaigns were organized to call attention to the public health crisis in Toronto's downtown core. Unsanitary drinking water, industrial pollution, and overcrowded housing were blamed for high rates of infant mortality and frequent outbreaks of infectious diseases. Urban reformers called for increased access to greenspace for the urban poor, as well as urban beautification to combat disease-causing filth. Wychwood Park's design emerged while debates about urban beautification took place. By making Toronto more livable, the aestheticized design of Wychwood Park also made it more symbolically British.

\section{Conclusion}

Through the re-territorialization process, Wychwood Park's landscape and its history became recoded as British territory, linking it to the cultural expressions of settler colonialism. For instance, when surveyor's lines were drawn across Mississauga territory, pre-existing boundaries were shifted in favour of a new paradigm of land distribution. When Marmaduke Matthews and Alexander Jardine registered a plan for subdivision bearing the name "Wychwood Park," land became re-territorialized under a new (British) name. The physical shifting of soil to create an earthen bridge and make room for more houses in the Park de-territorialized the physical shape of the earth. The Taddle Creek Ravine became re-territorialized as a bridge for foot and vehicle traffic. Taddle Creek, a former salmon-bearing stream that at one time ran the length of the City of Toronto, was dammed to create Wychwood Pond, a feature of the Park widely celebrated as a 
distinctive element of the Park's natural beauty. Davenport Road, a centuries-old Indigenous footpath that serves as the Park's southernmost border, was paved over in the late nineteenth century to facilitate streetcar traffic and integrate it into the industrialized urban environment. These acts shifted the physical integrity of the environment in which the Park sits, and enabled new land use practices and place-making discourses to occur.

Just as gardens serve as reminders of the gardener's labour, Wychwood Park's cultural Englishness serves as a reminder of the labour of re-territorialization. The labour of re-territorializing Wychwood Park was undertaken in part by artists and architects actively working to create an idealized residential environment. Their design of Wychwood naturalized the British colonial occupation of Toronto and worked to secure a sense of settler futurity and belonging.

In the next chapter, I document how the language and practice of public heritage worked to strengthen a sense of settler futurity and belonging. Just as settler indigenization was achieved through the aestheticization of space, in Chapter Five I argue that settler indigenization is also located in settler narratives of lineage and inheritance. As a heritage neighbourhood, Wychwood Park is celebrated as a piece of history that future generations can benefit from. Chapter Five unpacks in greater detail how public heritage approaches settler colonial history as a family genealogy, inviting the imagined national community to identify with settler forefathers. 


\section{Chapter Five \\ Indigenization II: Wychwood Park's Public Heritage}

Heritage, $n$.

1. That which has been or may be inherited; any property, and esp. land, which devolves by right of inheritance ...

2. The fact of inheriting; inheritance, hereditary succession ...

3. Anything given or received to be a proper and legally held possession ...

4. That which comes from the circumstances of birth; an inherited lot or portion; the condition or state transmitted from ancestors ...

5. Heirs collectively; lineage ...

Oxford English Dictionary

This chapter examines the ways Wychwood Park's significance contributes to the project of settler indigenization beyond the Park's gates. In particular, the art of George A. Reid, and the heritage efforts of late-twentieth-century residents to preserve a ceiling mural originally painted by Gustav Hahn, function to indigenize settler colonial society to the territories now referred to as the City of Toronto. Whereas the previous chapter argued that settler indigenization occurs through the aestheticization and reterritorialization of physical space, this chapter explores settler indigenization through the discourse of public heritage. Public heritage links past to present through narratives of kinship and inheritance that work to unite the imagined community of the Canadian settler nation. The concept of heritage indigenizes settler culture to Indigenous territory by inventing a cultural line of succession to legitimize settler origin storytelling and wed ruling settler classes under the guise of being cultural kin. Heritage, as a discursive tool of settler colonial society, allows settlers to transcend the limits of their biological lineage 
and establish a new line that inherits taste, civility, and national identity. The concept of heritage in a settler colonial society bestows inheritance privileges upon a class of immigrants previously excluded from accessing inheritance benefits in their contexts of origin. Finally, through the notion of heritage, settler colonialism's role in enabling masculine economic self-actualization is highlighted.

In this chapter I present two case studies. First, I explore pioneer themes in the art of George A. Reid. Two of Reid's most critically acclaimed paintings, as well as his public murals, portray the labour and family life of nineteenth-century settler pioneers. I argue that Reid's paintings contribute to a tradition of understanding settler farmers as national ancestors whose labour and land use facilitated the development of Canadian society. This tradition is indigenizing because it locates settlers as originary subjects in the national story. Further, settler labour is imagined to constitute the first significant use of colonial land, thereby reinforcing myths of empty land and idle Indigenous cultures. Reid's images contribute to a popular trope in Canadian settler storytelling whereby family scenes establish the significance of settler subjects. Within this trope, settlers embody gendered roles within family systems, fusing the concept of national development with the concept of patriarchal social organization in colonial territory. The familiarity of pioneer life - communicated through family portraits, gendered labour, and humanizing scenes - serves to indigenize settler culture to appropriated territories.

The second case study I examine in this chapter took place nearly a century later, in 1995, when the Wychwood Park community engaged in a campaign to preserve a church mural threatened with demolition. The Wychwood Park community argued that they were motivated to preserve the mural based on the fact it had been painted by Gustav 
Hahn. Positioning themselves as the inheritors of Hahn's legacy, late-twentieth-century Wychwood Park residents were invoked as kin by virtue of inhabiting the same neighbourhood. Situating contemporary settler neighbours as common descendants of earlier residents of the Park indigenizes settler culture to the region by promoting settler traditions that are based on occupying specific places and sites. This is important, as the legacy of Gustav Hahn is not only about good art, but also about identifying with built and natural environments, as though everyone who owned a particular house shares a common identity related to it. The campaign to preserve the Hahn mural illustrates how the language of heritage and inheritance functions to indigenize settler culture by promoting narratives of inter-generational belonging that ensure the continued regeneration of settler life.

\section{Settler Colonialism's Relationship to Inheritance}

As I summarized earlier, scholars of power and colonialism have documented how "notions and practices of manhood and womanhood were central to the twinned businesses of marginalizing Aboriginal people and designing and building a white society." As illustrated in Chapter Three, the marginalization of Indigenous people was achieved in part through the creation of a commodified land economy that deliberately excluded Indigenous people as participants. Granting private lots of land to male settlers not only built white patriarchal society, but also positioned male settlers as land owners thereby facilitating male economic self-possession through the settler colonial project. Unsurprisingly, cultural narratives of settler nationalism conventionally promote the trope

\footnotetext{
${ }^{1}$ Adele Perry, On the Edge of Empire: Gender, Race, and the Making of British Columbia 1849-1871 (Toronto: University of Toronto Press, 2001), 19.
} 
of the "journey to manhood ... whose fulfillment depends on the protagonist's journey north towards successful indigenization." ${ }^{2}$ Settler colonial space was achieved both by eliminating Indigenous land title and by facilitating settler men as property owners. Part of settler colonialism's appeal to settlers, in other words, was the possibility of achieving masculine self-actualization through land ownership. This was certainly true for those classes of male settlers who had never owned property before, as well as for wealthy Loyalist settlers to whom postwar reparations were paid in part through land. For others, land ownership in what became Canada was a departure from British inheritance custom.

Marlene Goldman situates the significance of land ownership to British men in the context of British imperialism, arguing that the rule of primogeniture dictated that firstborn sons inherited all family wealth, leaving younger sons without comparable means. Primogeniture was an unwritten law until 1833, and practiced until $1925 .{ }^{3}$ For some, this created a form of "compulsory mobility," whereby younger sons were forced to leave home and work abroad in different areas of imperial trade. ${ }^{4}$ The rule of primogeniture has been characterized as a form of dispossession, one that produced trauma in younger sons. ${ }^{5}$ More importantly, primogeniture reflects an economic system that is reliant on patrilineal inheritance and maintains hierarchies within families on the basis of gender and birth order. I do not mean to overstate the role primogeniture played in the colonization of Ontario; however, the significance of primogeniture as a cultural and legal custom offers a reflection of the dynamics surrounding how land ownership was associated with

\footnotetext{
2 Marlene Goldman, DisPossession: Haunting in Canadian Fiction (Montreal: McGill-Queens University Press, 2012), 74.

${ }^{3}$ Zouheir Jamoussi, Primogeniture and Entail in England: A Survey of Their History and Representation in Literature (Cambridge: Cambridge Scholars Press, 2011), 2.

${ }^{4}$ Goldman, DisPossession, 78.

${ }^{5}$ Goldman, DisPossession, 72.
} 
patrilineal power, civility, wealth, and political autonomy in the eighteenth and nineteenth centuries. By exploring the construction of primogeniture as a classed, gendered, and racialized value, the political-economic context of the settler colonial project can be more fully understood.

The rule of primogeniture was in place in Britain (and Canada) ${ }^{6}$ simultaneous to the height of the transatlantic slave trade and British imperialism. Goldman argues that being a younger son dispossessed of one's family wealth carried a stigma, owing to the "harsh binary logic of the eighteenth century, wherein if one does not own property, then one is susceptible to being viewed and treated as property."7 To be a dispossessed son, according to Goldman, was to be haunted by the threat of slavery, because "the slave epitomized dispossession and constituted the antithesis of the age's ideal of the civilized, self-possessed gentleman." " To be a civilized self-possessed gentleman was not merely a matter of wealth. Rather, civility in the eighteenth and nineteenth centuries was inflected with hierarchical ideas about race and human progress that were deployed in the service of imperial expansion. To be known as civilized was a matter of biology in the context of race, but it was also used to distinguish classes of British society. Sons of wealthy families imagined themselves to be civilized, but were constantly threatened with degeneration - literally "to lose the properties of the genus, to decline to a lower type" if the one family heir were to mismanage the family fortune. ${ }^{9}$ Second sons were imagined to be "genealogically, culturally, and evolutionarily degenerate" ${ }^{10}$ based on their lack of

\footnotetext{
${ }^{6}$ Canada abolished the rule of primogeniture in 1852 .

${ }^{7}$ Goldman, DisPossession, 75.

${ }^{8}$ Goldman, DisPossession, 75.

${ }^{9}$ Goldman, DisPossession, 77. Here, Goldman is quoting Edward Chamberlin and Sander L. Gilman, Degeneration: The Dark Side of Progress (New York: Columbia University Press, 1985), xi.

${ }^{10}$ Goldman, DisPossession, 77.
} 
inheritance and class mobility. Consequently, "the powerful rule of primogeniture was mirrored by its conceptual opposites - slavery and degeneration.",11

While Goldman's argument is focused specifically on the symbolically dispossessed second son, her insights about the construction of land ownership and patrilineal succession remain salient for the study of settler colonialism in Canada more generally. In the late eighteenth century and throughout the nineteenth century, as appropriated land in what is now Ontario was being granted to settlers in the name of establishing a "new" society, owning land was a symbol of regeneration - gaining properties of the genus, to be raised to a higher type and ensure a future line of succession. Slavery and degeneration haunted access to land in what is now Ontario - and the "harsh binary logic" that one could either be property or own property remains an accurate (albeit provocative) way of understanding what being a landholder meant for the thousands of settlers whose names began to adorn Canadian patent maps. The threat of degeneration in settler colonial society took many forms. Cultural degeneration loomed constantly, as nation-builders made arguments for building cultural institutions that could rival "older" countries like those in Europe. Economic degeneration was always a drought, American tariff, or mortgage away for many farming settlers. The threat of sexual and racial degeneration is reflected in laws that regulated sexuality, "miscegenation," and marriage, as well as the efforts to civilize immigrant urban populations that I document in Chapter Six. In sum, establishing a settler colonial society was done in the interests of generation - building a lineage as well as guarding against degeneration.

\footnotetext{
${ }^{11}$ Goldman, DisPossession, 77.
} 
Heritage as a discursive tool of settler colonial society narrates the terms of lineage, succession, and legacy. The kind of history that settler society seeks to preserve, the spaces and sites declared monumental, and the ways settlers are encouraged to claim relationship to each other are all accomplished by and through the idea of public heritage. Further, the promotion of Canadian history as a settler story obfuscates the "very notion of settlement [as] premised on a denial of Aboriginal priority". ${ }^{12}$ Themes of lineage and heritage serve the interests of settler colonial power as they assert familial origins within a national story that in many ways was haunted by the threat of disinheritance, degeneration, and orphaning. In what follows, I explore how George A. Reid's pioneer scenes, and the 1995 campaign to preserve a mural painted by Gustav Hahn, promote settler heritage as an indigenizing device. In particular, the discourse of heritage constructs an imagined national community through familial tropes, constructing settler colonial belonging as an inherently gendered dynamic.

\section{Constructing Heritage in Ontario: The Cult of the Pioneer}

In the late nineteenth century there was an organized push to commemorate settler history in the form of a grand narrative that would recount the founding of Canada as a nation. Many involved in historical associations envied the commemorative efforts they witnessed taking place in the United States. The centennial celebrations of the declaration of independence in 1876, the centennial of the Evacuation of New York in 1883, the centennial of George Washington's inauguration in 1889, and the World's Columbian Exhibition in Chicago in 1893 marking four hundred years since the so-called

\footnotetext{
${ }^{12}$ Cynthia Sugars, "Repetition with a Difference: The Paradox of Origins in Alistair MacLeod's No Great Mischief" Studies in Canadian Literature/Etudes en Literature Canadienne, 33 no. 2 (2008):147.
} 
"discovery" of the Americas ${ }^{13}$ appeared to give Americans a sense of a "national, unifying history"14 that had yet to be successfully mounted in Canada. The United States was not the only country actively producing its public past. In France, the annual Bastille Day festivities began in 1880, and the Revolution's centennial celebrations took place in 1889. In Germany, so many historical events and figures were being recognized with such regularity that a national festival society was formed in $1889 .{ }^{15}$

Historical and pioneer societies were formed for the purpose of recording oral histories of original Loyalist settlers who, as a generation, were beginning to die in the middle of the nineteenth century. Popular interest was sustained in the history of Loyalist settlement and many memoirs and biographical newspaper profiles were published across the province, recounting stories of "wolves, wildcats, 'savage' Indians, swarms of mosquitos, fever-infested swamps, and poisonous snakes ... days of 'dearth and famine' during which many were said to have been reduced to surviving on the leaves of trees, herbs and ground nuts ... such hardships were character building, instilling industrious habits and trust in Providence." ${ }^{\prime 16}$

The late nineteenth century witnessed a proliferation of historical writing that chronicled both the Loyalist settlement of Upper Canada, as well as the personal histories of individual pioneers. Books such as William Canniff's The History of the Settlement of Upper Canada (1869) and Egerton Ryerson's The Loyalists of America and Their Times from 1620-1816 (1880) served to remind contemporary audiences to "cherish the

\footnotetext{
${ }^{13}$ In listing these events I am paraphrasing Norman Knowles's discussion about increased historical commemoration in Inventing the Loyalists: The Ontario Loyalist Tradition and the Creation of Usable Pasts (Toronto: University of Toronto Press, 1997), 7.

${ }^{14}$ Gerald Killan, Preserving Ontario's Heritage: A History of the Ontario Historical Society (Toronto: Ontario Historical Society, 1976), 24.

${ }^{15}$ Knowles, Inventing the Loyalists, 7.

${ }^{16}$ Knowles, Inventing the Loyalists, 35 .
} 
remembrance and imitate the example of their forefathers. ${ }^{, 17}$ Henry James Morgan's Sketches of Celebrated Canadians (1865); G. Mercer Adam's Prominent Men of Canada (1892); Edward Marion Chadwick's Ontarian Families (1894); and John Alexander Cooper's Men of Canada (1902) worked to create national ancestors of early settlers. The most popular form of historical writing was genealogy, reflected in the creation of Ontario Genealogist and Family Historian magazine in $1898 .{ }^{18}$ Local histories emphasized the labour of settlers, with "detailed descriptions of the pioneer way of life, with chapters devoted to clearing the land; building a log cabin; clothing; cooking; the making of soap, candles, and maple syrup; and amusements and pasttimes. ${ }^{, 19}$ Such accounts sentimentalized farming, and promoted a sense of excessive familiarity with the day-to-day minutiae of pioneer life. Settler culture in Ontario was discursively constructed as a family tree, with the genealogical and biographical narratives inviting a familial association with originary settlers.

Rural settler labour was codified through these texts as nation-building. The detailed, exhaustive accounts of daily tasks created scenes in which to imagine and identify with the history of settler pioneers. Unlike the nation-building narratives that were located on revolutionary battlegrounds (as in the United States) or storming urban fortresses (as in France), the Canadian story became enacted in rural farm scenes. Importantly, the focus on male settler farmers as nation-builders and national ancestors was becoming institutionalized as public history at the same time that immigration was being promoted in western Canada. Throughout the 1880s and 1890s, farmland was offered for free to homesteaders in the prairies. Agricultural labour was imagined as a

\footnotetext{
${ }^{17}$ Knowles, Inventing the Loyalists, 34.

${ }^{18}$ Knowles, Inventing the Loyalists, 104.

${ }^{19}$ Knowles, Inventing the Loyalists, 103.
} 
nation-building act. That farmers were exalted as national heroes and positioned as active, productive subjects in relation to an uncultivated wilderness reinforced the myth and sensibility that Canadian land was empty (and unused) prior to the arrival of Europeans. By transforming forests and grasslands into working farms, settlers were thought to have civilized the landscape, rendering it productive and profitable, and ushering in the conditions for modern society. As Ontario was narrating its agrarian history as heroic, Manitoba, Saskatchewan, and Alberta could be anticipated as coherent possibilities within a national story. The symbolic pioneer legitimized the land distribution schemes that created of the United Empire Loyalists a class of landholders, and it further legitimized colonial expansion westwards. This cultural tradition of settler indigenization - investing in a national origin story that is predicated upon the appropriated landscape - is a tradition George A. Reid was actively participating in and promoting.

From 1888-1889, Reid lived in Paris, studying with Benjamin Constant at the Académie Julian, and taking classes at the Académie Colarossi. These schools were alternatives to the state-funded Ecole de Beaux Arts, where pupils competed annually for the Prix de Rome - a prize restricted to French nationals. By studying in Paris, Reid participated in a longstanding custom of foreign students travelling to Paris to study art with French masters in their private studios. Reid's training emphasized the human figure, as well as realist scenes from everyday life. Reid applied his European training to distinctly Canadian scenes in an effort to build a Canadian aesthetic. A strong example of his interpretation of realism is Logging (Figure 5.1). 


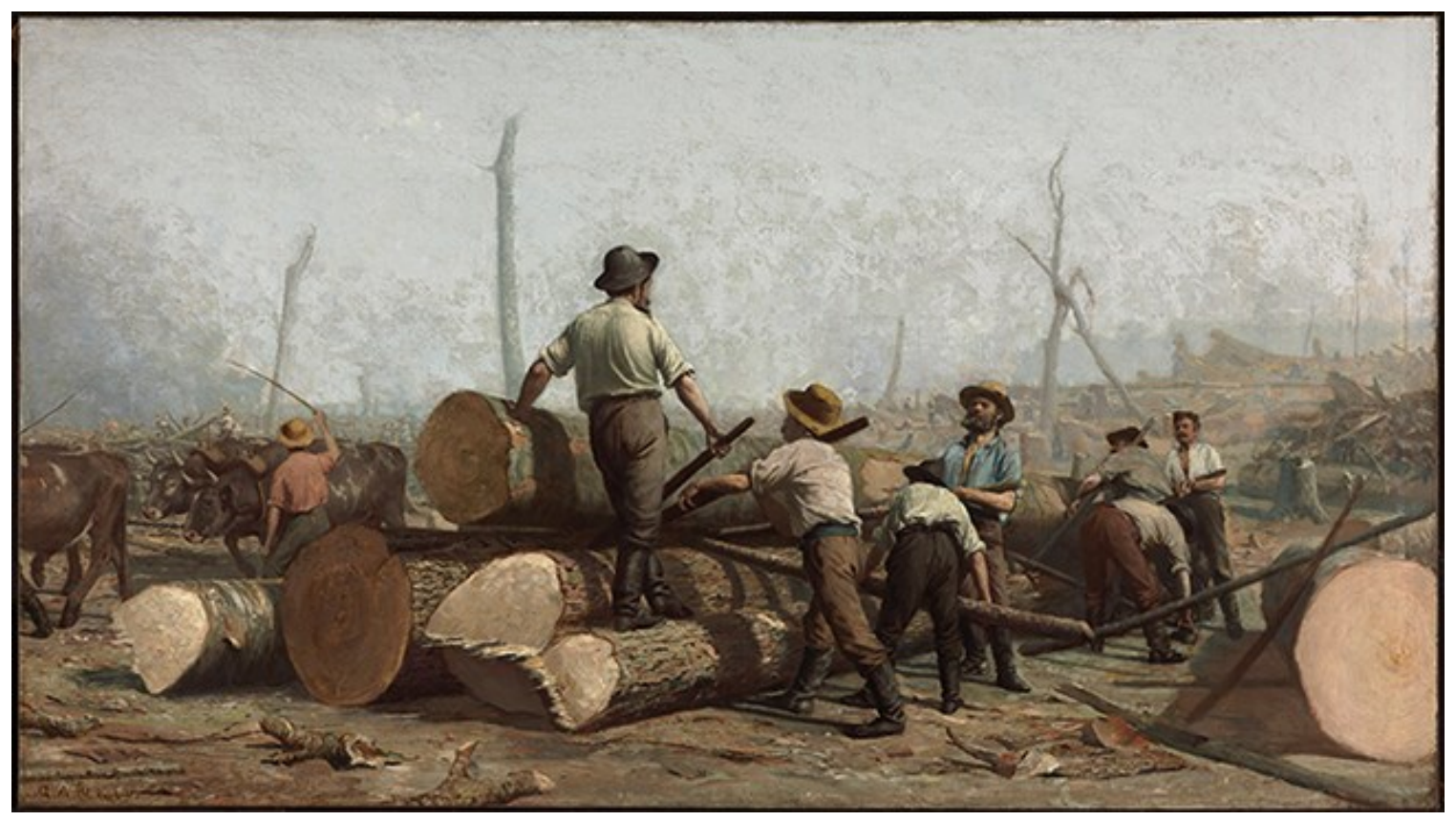

Figure 5.1 George A. Reid, Logging, 1888. National Gallery of Canada.

In Logging, a group of men are depicted in the middle of a logging bee - a cooperative tradition in rural Ontario for clearing land for farming in the mid-nineteenth century. As Reid writes, "finding a log yard near my [Paris] studio in which there were great logs resembling those found in Canada, I seized the opportunity to paint a Canadian picture. ${ }^{20}$ Logging demonstrates Reid's nationalism, insisting upon a Canadian iteration of his academic training. Significantly, Logging engages with the late-nineteenth century interest in rural peasant scenes. Unlike European genre paintings, where rural peasants were depicted as underfed and suffering, the rural workers in Logging appear engaged, active, and in the middle of a large and demanding task. Logging depicts workers worthy of admiration and recognition - the kinds of men whose daily labour was codified in the diaries and biographies mentioned earlier. Logging acknowledges cooperative traditions

\footnotetext{
${ }^{20}$ George Reid Fonds, Scrapbook I, p. 132. E.P. Taylor Reference Library, Art Gallery of Ontario, Toronto.
} 
of labour among early rural settlers, as well as the lack of market demand for timber. ${ }^{21}$ The workers are clearing land to make room for a new agricultural economy, reterritorializing the landscape as a source of settler labour, territorial identification, and future wealth. The labour of logging is de-territorializing labour - taking away the land's capacity for traditional use, enabling a new way of knowing and using land to become established.

While the land in Logging is a significant feature, the subject of the painting is the labour of the farmers. They are working together, forming community with each other across vast piles of felled trees. The landscape around them is faded by the dust and woodchips in the air - the fog of their labour. As a uniquely Canadian scene, this painting is reminiscent of the particular conditions of settler society. Symbolically, the settlers in Logging are representative of the values associated with pioneering Canadians. Endurance in the face of hard work, cooperation to ensure mutual survival, and skill at transforming forests into productive farms constitute common themes in images and narratives of pioneers that circulated in the late nineteenth century. These scenes indigenized settler society to North American territory - they provided a unifying narrative in which settler society could story its social beginnings.

Logging is constitutive of a broader trend in Canadian art at the turn of the twentieth century: the cult of the pioneer. The celebration of pioneer life at the turn of the twentieth century in Toronto fuelled the development of a national consciousness premised upon a settler colonial interpretation of land and its social, cultural, and political economic meanings. Over the next few decades, George A. Reid painted innumerable pioneer scenes, both as individual art works and as public murals. Reid's pioneer scenes

\footnotetext{
${ }^{21}$ George Reid Fonds, Scrapbook I, p. 132. E.P. Taylor Reference Library, Art Gallery of Ontario, Toronto.
} 
depict settler labour as laying a foundation for Canada's future. Reid's art illustrates a settler orientation to the Canadian landscape, one whereby settler labour adds value to an otherwise unproductive wilderness. Representing pioneers as national ancestors legitimizes the British claim to land, naturalizes the settler presence upon it, and disavows Indigenous land claims and pre-colonial land use systems.

Reid's 1890 painting, Mortgaging the Homestead (Figure 5.2), is one of his most critically acclaimed pictures.

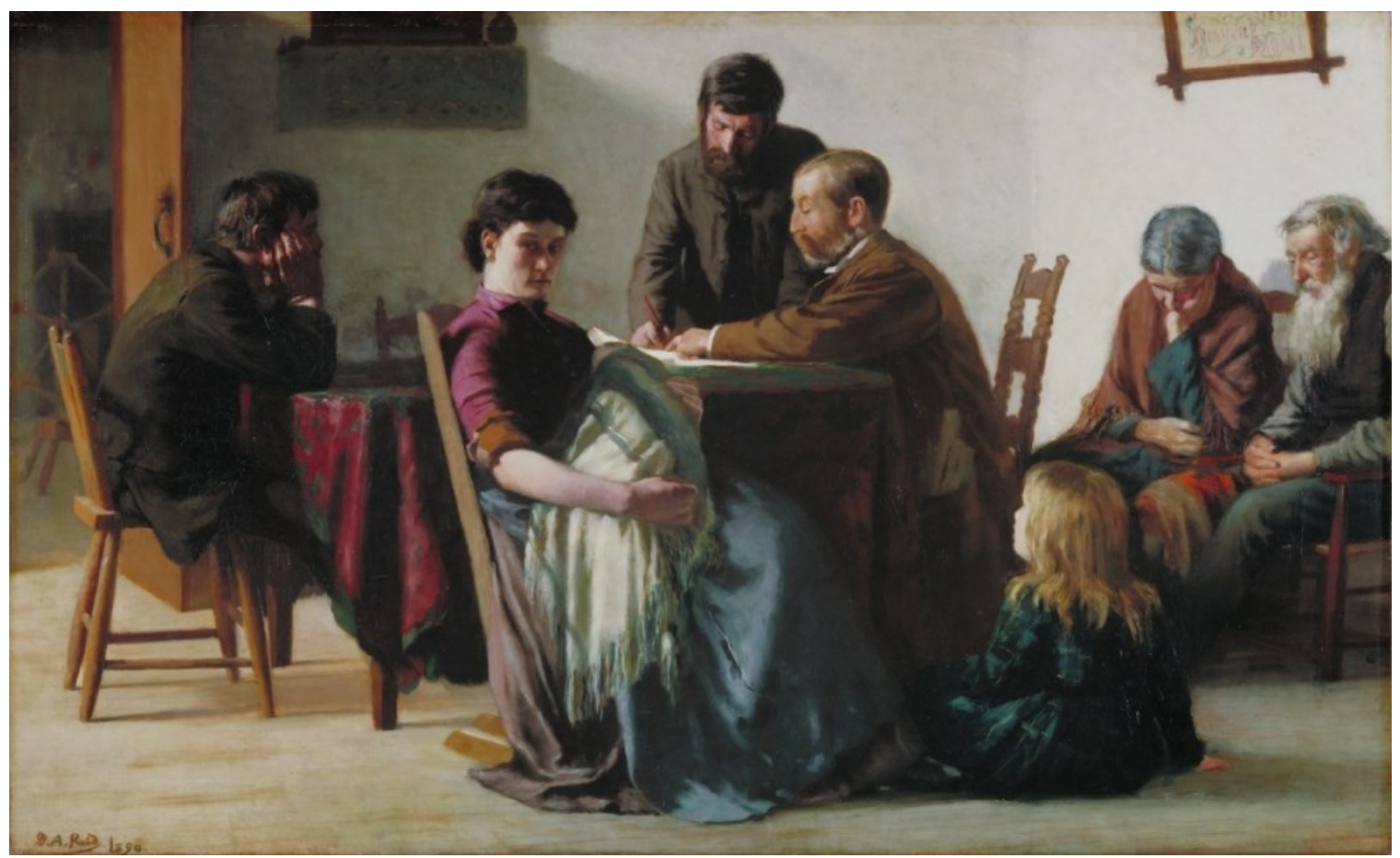

Figure 5.2 George A. Reid, Mortgaging the Homestead, 1990. National Gallery of Canada.

Mortgaging features an interior scene of a farmer signing mortgage papers facilitated by a lawyer while his family appear worried and sad. In particular, the farmer's wife looks directly at the viewer with a foreboding expression while holding an infant. The painting conveys an anxious message with regards to the future (symbolically represented in the form of the baby), and viewers are encouraged to consider the mortgage to be a threat to 
the family's future security and prosperity. Mortgaging is successfully read as a tragic scene precisely because of settler colonial cultural logics. A mortgage is only a hardship if the family is presumed to deserve arable land to farm for free in the first place. In this way, scenes like Mortgaging promote and establish settler colonial ways of knowing while also performing the instructive function of teaching the viewing public to forget about Indigenous land claim, land use, and settler territorial appropriation.

Mortgaging did not convey its Canadianness through a distinctive landscape scene, such as the iconic Rocky Mountains or Niagara Falls. Rather, it was recognizably Canadian because it depicted the moral sincerity of a pioneer family. Certainly, Mortgaging is a depressing picture, but its sombre tone relies on the idea of a mortgage being conceptualized as an injustice. The socio-economic logics that conspire to render Reid's scene as tragic depend upon the viewer's acceptance of pioneer labour as inherently valid labour. In particular, pioneer labour is distinctly masculine labour, and in Mortgaging the viewer witnesses the emasculation of the pioneer hero who, according to the discursive tradition I have outlined, may as well be "our" favourite grandfather.

The cultural celebration of pioneers as "at home" in the Canadian countryside disavows the displacement of Indigenous lives, land use, and territorial jurisdiction that was required as a prerequisite for European settlement. By finding themselves in a position where they required a mortgage, the family depicted in Mortgaging was becoming distanced from the promise Canada had offered original settlers of free land grants. Further, taking on a mortgage suggests that they were laboring in vain. In Mortgaging, Reid was able to convey the tragedy that poverty presents. The success of the picture in being read as both tragic and particularly Canadian reflects the extent to 
which pioneer farmers had become assimilated as hard-working national heroes within the Canadian cultural imagination. The logic at work in Reid's scene implies that the potential bankruptcy of the descendants of pioneers would be a national tragedy. In this way, the themes in Reid's artwork buttressed already existing national myths that imagined the settler-pioneer as a founding hero in the national story. This originary myth legitimized the British settlement of Ontario, in particular, while disavowing Indigenous claim to the territory. Further, this positioned settler-farmers as national leaders during an era in which the Canadian government and the CPR railway were actively seeking settlerfarmers to establish permanent communities across the prairies.

The symbolic pioneer was mobilized in education curriculum, commemorative activities, biographical writing, and the emerging canon of Canadian art. As a community leader, Reid worked to form coalitions and advocate for art to be accessible to all. One of the ways public taste could be cultivated was through mural art. In an effort to continue building an artistic tradition in Canada, Reid began applying his interest in pioneer scenes to the production of public murals.

George Reid's exposure to mural art in the United States, England, and France informed his desire to bring the mural movement to Canada. In February 1894, Reid established the Society of Mural Decorators with his colleagues William Cruickshank, Wyly Grier, Frederick Challener, Curtis Williamson, Sidney Strickland Tully, and Harriet Ford. The Society petitioned unsuccessfully to paint a mural scheme in Toronto's Union Station, and began proposing a set of murals for the new Toronto City Hall, under construction at the time. Writing to E.J. Lennox, architect of the building, the Society of Mural Decorators explained that they wished to "guard against inadequate interior 
decoration and initiate a scheme to emulate the notable examples of decoration in public buildings in the UK, France, the United States, and others." ${ }^{22}$ Therefore, murals would enable Toronto to participate in an international standard for public building decoration. By initiating a mural scheme, the Society hoped to advance Toronto's artistic status, an advancement that some dreamed could render the city the "Ravenna of the future. ${ }^{, 23}$ Reid and his artistic colleagues proposed not only to produce a mural scheme in public buildings, but to assist in advancing the cultural sophistication of the Canadian nation through public art.

The mural proposal consisted of six large panels to be painted in the Council Chamber. The first three panels were to illustrate the city's motto, "Industry, Integrity, and Intelligence," with historical scenes of the city's founding, and the second set of three panels were to be titled "Peace, Government, and Prosperity" and depict pioneer scenes. Two additional hall panels were proposed, entitled "Art" and "Science." ${ }^{24}$ City Council ultimately decided they could not justify the cost of the proposed murals, and voted against the scheme. In December 1897, George Reid offered to paint some murals for free, in order to generate public interest. The city accepted. Two large Entrance Hall panels were formally presented to the city in May 1899. Measuring seven by fourteen feet, The Arrival of the Pioneers is located on the east side of the entrance arches, and depicts four men and one woman (holding a baby) in a forest, carrying sleeping rolls on their backs. To the west of the entrance arches is Staking a Pioneer Farm, again in a forest, with eight men armed with surveying tools and axes - one of the sitting on a

\footnotetext{
${ }^{22}$ Letter to EJ Lennox, quoted in Charles C. Hill "For an Integration of the Arts" in Artists, Artisans, Architects, 136-7.

${ }^{23}$ James Mavor, quoted in Charles C. Hill, "For an Integration of the Arts" in Artists, Artisans, Architects, 137.

${ }^{24}$ Charles C. Hill, "For an Integration of the Arts" in Artists, Artisans, Architects, 137.
} 
recently felled tree - measuring land. In Staking, there is an Indigenous man observing in the background, watching passively as the pioneers work together, reminiscent of the Indigenous figure in the foreground of Benjamin West's Death of General Wolfe (Figure $5.3)$.

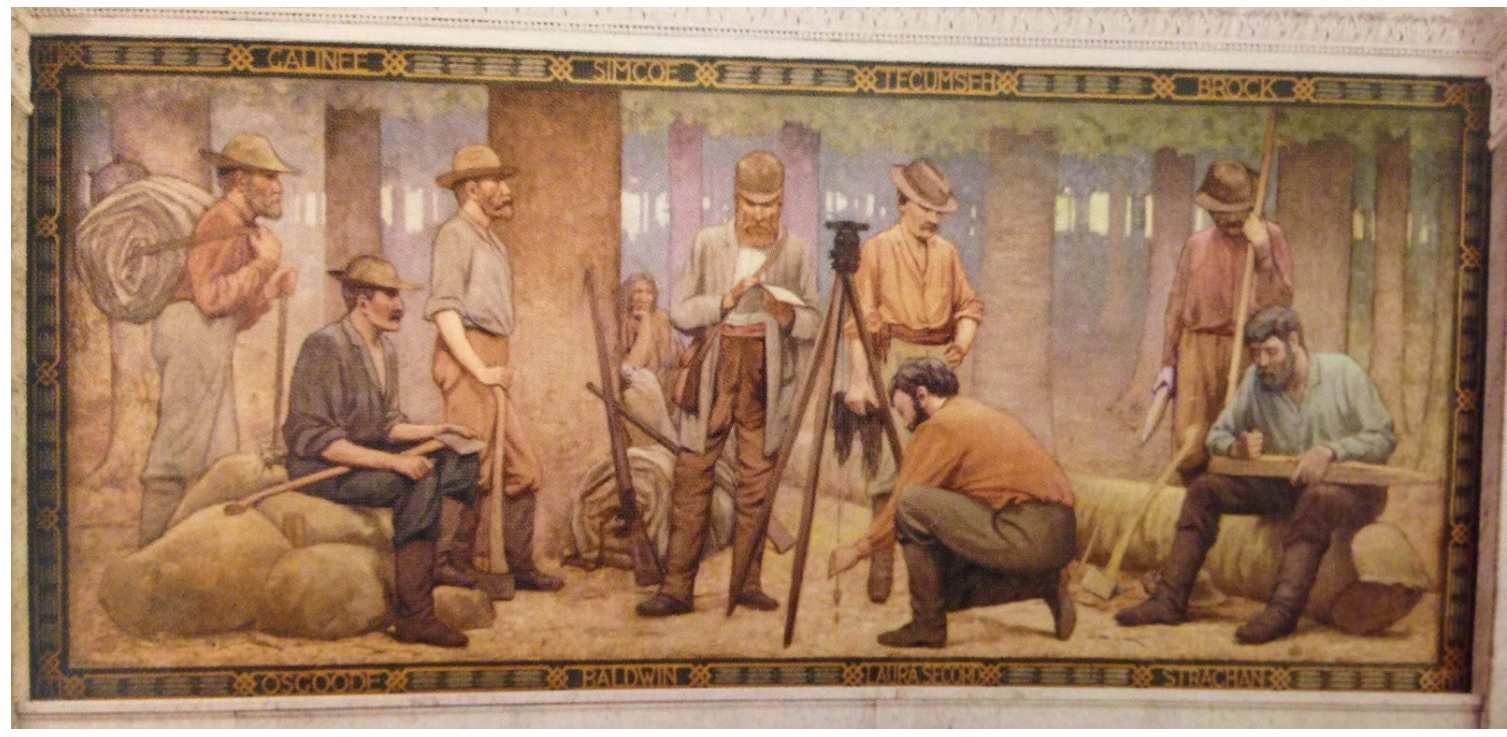

Figure 5.3 George A. Reid, Staking A Pioneer Farm, 1900. Toronto Municipal Buildings. http://vancouver-mastersgalleryltd.blogspot.com/2015/02/the-arts-and-crafts-movementand.html

Between the arches, Reid painted four female allegorical figures symbolizing "Discovery," "Fame," "Fortune," and "Adventure." The allegorical figures hold a banner that reads "Hail to the Pioneers/ Their Names and Deeds/ Remembered and Forgotten / We Honour Here." 25 Along the edge of each mural panel is a decorative frame bearing the names of significant figures from Toronto and Ontario's history, chosen by the Canadian Historical Society: Galinée, Simcoe, Tecumseh, Brock, Osgoode, Baldwin, Laura Secord, and Strachan. ${ }^{26}$

\footnotetext{
${ }^{25}$ Rosalind M. Pepall, "The Murals by George A. Reid in the Toronto Municipal Buildings, 1897-1899” (Master's thesis, Concordia University, 1982), 147.

${ }^{26}$ Charles C. Hill, "For an Integration of the Arts," in Artists, Artisans, \& Architects, 138.
} 
The Society of Mural Decorators, reorganized as The Guild of Civic Art (TGCA), lobbied diligently for City Council to commission a larger mural scheme for City Hall. After Reid's murals were installed, the TGCA returned to City Council with a revised proposal. This time, the pioneer theme was expanded over a fourteen-panel plan. ${ }^{27}$ Titles included "Early Cultivation, Clearing the Land, Felling the Forest, Building a Log Cabin, Treaty with the Indians, Hunters' Camp, Long Portage and Early Missionaries. ${ }^{28}$ Once again, City Council rejected the proposal. However, the surviving maquette reinforces the significance of pioneer scenes for the Reid and TGCA. In their desire to advance the cause of Canadian art and decorate the industrializing City of Toronto, the TGCA sustained a concentrated focus on pioneer themes as the visual language with which to position Toronto as a world-class city and narrate a heroic past that indigenized settler society to the colonial landscape.

Reid's pioneer art promoted the idea that white masculine agrarian labour was part of Canada's heritage. The scenes I have discussed encouraged late-nineteenth-century Torontonians to identify with pioneers as familial ancestors responsible for passing down the possibility of international grandeur and cultural prestige. As I will illustrate in the following section, a similar relationship to inheritance was articulated by late-twentiethcentury Wychwood Park residents as they campaigned to preserve a mural painted by Gustav Hahn.

\footnotetext{
${ }^{27}$ The only published photograph of the plan is in Charles C. Hill, "For an Integration of the Arts," in Artists, Architects, \& Artisans, ed. Charles C. Hill (Ottawa: National Gallery of Canada, 2013), 140-1.

${ }^{28}$ Hill, "For an Integration," 139.
} 


\section{St. Paul's United Church Fire}

In 1993, St. Paul's United Church, located north of Bloor St. on Avenue Road, was sold to a real estate developer, who promptly applied for a demolition permit to destroy the building and build a condominium development in its place. This news was devastating to those concerned with Toronto's art and architectural history: the ceiling of St. Paul's was one of former Park resident Gustav Hahn's largest mural commissions, and distinguished itself as one of the best preserved examples of an Art Nouveau mural in Canada. A well-organized campaign opposing the demolition of the Church was launched. Albert Fulton, Wychwood Park's community archivist and local historian, organized the Wychwood residents to participate. His personal archive of Wychwood Park ephemera (now housed in the municipal archives) contains a file of letters sent to the chair of the Neighbourhoods Committee at City Hall, protesting the demolition permit and calling on City Council to prevent the destruction of St. Paul's United Church. The letters mobilize a discourse to preserve the Hahn mural that reiterates many of the same tropes of temporality and national ambition that were used to advocate for public art in schools a century before - a theme I explore in further detail in Chapter Six.

"The ceiling is of special, irreplaceable and historic value as one of the few remaining works of Toronto's finest - Gustav Hahn ... It is not necessary to tear down masterpieces under the auspices of progress!" wrote one Wychwood Park resident. ${ }^{29}$ "This unique work of art is invaluable to our heritage," wrote another. ${ }^{30}$ Two more residents declared, "This painting should be preserved as part of our Canadian heritage.

\footnotetext{
29 "Letter from Caudwell/Brooks," in 1993 Protests Against the Demolition of St. Paul's, Series 1541, File 119, Fonds 128, City of Toronto Archives. Emphasis in original.

30 “Letter from Leonard Oesterle," in 1993 Protests Against the Demolition of St. Paul's.
} 
Demolition of this ceiling and destruction of this painting should be considered an act of cultural vandalism." ${ }^{\prime 11}$ The then-current resident of Gustav Hahn's house wrote:

Can one imagine the loss to the artistic heritage of Rome and the Catholic Church if the Church had received a demolition permit leading to the destruction of the Michelangelo ceiling paintings in the Sistine Chapel because they felt the building wasn't worth preserving? ... As the present owner of the house in Wychwood Park designed and built by Gustav Hahn, I am most grateful for the evidence of the Hahns' artistic talents which I became custodian of when I bought the house. ${ }^{32}$

Included with the letters from concerned citizens were letters of concern from museum administrators, noted artists, and local historians. Curators from both the Royal Ontario Museum and the National Gallery of Canada wrote sympathetic letters establishing Gustav Hahn as "one of the leading decorative artists working in Toronto at the turn of the century," ${ }^{33}$ an artist whose family "has given so much to the artistic life of Toronto over several generations" such that "this threat to Gustav Hahn's work is a serious blow to the Hahn legacy." ${ }^{34}$ The William Morris Society expressed their opposition to the destruction of the building. A former art student of Gustav Hahn's wrote to oppose the development proposal. Editorials from Toronto newspapers voicing opposition to the proposal were attached to the letters. Photocopied pages from architectural histories of Toronto were included, building the case that St. Paul's United Church was too valuable a cultural asset to demolish. City Council agreed. The Neighbourhoods Committee promptly passed a motion to "Do everything in its power, within the legal parameters that exist, to ensure that 121 Avenue Road is preserved." 35

\footnotetext{
31 "Letter from Joan Harrison and Donald Harrison," in 1993 Protests Against the Demolition of St. Paul's.

32 "Letter from Joan Cunningham," in 1993 Protests Against the Demolition of St. Paul's.

33 "Letter from Charles C. Hill," in 1993 Protests Against the Demolition of St. Paul's.

34 "Letter from Alison Harle Easson," in 1993 Protests Against the Demolition of St. Paul's, CTA.

35 "December 2, 1993 minutes of the Neighbourhoods Committee, City of Toronto," in 1993 Protests Against the Demolition of St. Paul's.
} 
After two years, no agreement was reached between the developer and the City, and St. Paul's United Church was set on fire. No insurance claim resulted because of strong suspicions of arson. The site is now home to an upscale retirement residence. Only photographs of Hahn's ceiling mural remain. Reflecting on the Church's destruction, a Globe and Mail columnist praised Hahn's mural for its ability to transform "an otherwise unimportant building into a landmark on the historical map of Canadian decorative art." ${ }^{, 36}$ The campaign to preserve St. Paul's United Church, as well as the way the cultural significance of the mural was framed discursively in the letters and editorials I have cited, reflects social, political, and ideological themes that inform the cultural significance of the Wychwood Park community. Perhaps most obviously, the Wychwood Park community was well organized, writing letters as part of a concerted campaign to achieve a shared social vision. While the tone of their letters was emphatic when describing the "cultural vandalism" they wanted to prevent, they were not rigidly opposing development at all costs. Wychwood residents were careful to temper their protests by offering solutions oriented around a mutual benefit. "We implore you to deny a demolition permit for this building, unless the ceiling painting can be preserved for future generations to cherish,", ${ }^{37}$ one letter conceded. "I am assured it would be easily possible to find a way to preserve St. Paul's without entirely halting development on the general site, and there are numerous precedents for this in Toronto and elsewhere,"38 another suggested. "Rather than demolishing the church, I see its retention as a major asset to any redevelopment of the site. Ideally it should be retained as it is, restored for

\footnotetext{
${ }^{36}$ John Bentley Mays, "The Trouble with Angels," Globe and Mail, May 17, 1995, in 1993 Protests Against the Demolition of St. Paul's.

37 "Letter from Joan Harrison and Donald Harrison," in 1993 Protests Against the Demolition of St. Paul's.

38 "Letter from Jeremy Hold and Janet MacLean," in 1993 Protests Against the Demolition of St. Paul's.
} 
use as a theatre, restaurant, library, museum or gallery, or as the spectacular entrance lobby for a new building to the rear,"39 offered another.

These comments clarify the political goals of the protest (preservation of the ceiling specifically rather than the entire building), but they also point to a relationship to institutional power that is less antagonistic than it is conciliatory. The letters sent in protest take on a stern but sympathetic tone towards city councillors. As the letters attest, there was no ideological opposition to infrastructure nor economic development in the arguments used to advocate for the church's preservation. In this story, what distinguished the Wychwood community's values from the business development overseen by City Hall is a learned appreciation for the arts. Not only did the Wychwood community understand itself as one concerned about the preservation of Toronto's art history, but it had the capacity to mobilize expert support for their cause, as evidenced by letters they solicited from museum curators, leaders of local history organizations, as well as the William Morris Society. The Wychwood Park community remains an elite community, certainly, but their social and political power is not restricted to economic wealth. Rather, they constitute what Antonio Gramsci would call a "cultural leadership class, ${ }^{, 40}$ occupying a place in a capitalist class structure not tied to owning the means of production but instead establishing a sense of taste and cultural expertise in the society.

Significantly, the discourse used to advocate on behalf of "good taste" was, in this instance, a temporal discourse. By preserving the St. Paul's ceiling mural, City Council was invited to consider their decision as a prescient one - preserving the Sistine Chapel of tomorrow. Similarly, "progress" at all costs was framed as a damaging value to "our

\footnotetext{
39 "Letter from Albert Fulton," in 1993 Protests Against the Demolition of St. Paul's.

${ }^{40}$ Stuart Hall, “Gramsci's Relevance for the Study of Race and Ethnicity," Journal of Communication Inquiry 10, no. 2 (1986): 15.
} 
Canadian heritage." Hahn's mural transformed an "otherwise unimportant building" into a "landmark on the map of historical decorative art." The logic mobilized to frame the significance of Hahn's painting draws a link between art and time. Art was re-framed as evidence of a shared, "national" heritage that enabled places and people to be placed on a "map" of time. Therefore, preserving art was important because it linked the past to the present, particularly because that "past" was constructed as a shared past in the context of an imagined national (settler) community. The kind of future imagined for Toronto, if its early settler artwork were to be properly preserved, could rival Vatican City in its cultural significance. The cultural reference points used to assess Canada's national progress remain European within the logic used by Wychwood residents, a strategy that implicitly reinforces the idea of Canada as "new land" and Indigenous history as non-existent.

By defending the need to preserve Hahn's mural, the residents of Wychwood Park in 1993 asserted themselves as stewards of Hahn's legacy, drawing a direct connection between 1993 and 1906, when Hahn moved into the Park. However, the campaign to preserve St. Paul's United Church was not related to the Park's founding merely because of this artistic legacy. In campaigning to preserve part of Toronto's architectural heritage, the 1993 residents participated in a longstanding tradition of the Wychwood Park community: working in coalitions with other individuals and organizations to promote civic beautification. This form of civic advocacy has, for a century, used credentialized expertise to legitimize its arguments, positioned the need for beautification as benefitting the common good, and characterized urban development in temporal terms - promising that the future would be stark or promising depending on the action taken in the present moment. Most importantly, Canada's promise as a nation was positioned as contingent 
upon the preservation of Hahn's mural. By positioning their interests in the mural preservation by citing their neighbourhood, Wychwood Park residents established themselves as members of an imagined community tasked with ensuring Canada's progress. The community's advocacy was one of many examples whereby the Park is associated as a source of cultural refinement for the City of Toronto - a theme I will explore in Chapter Six. Further, Wychwood Park's cultural refinement was imagined as inheritable through land transactions, a process that situates generations of settlerhomeowners as sharing similar goals, tastes, and social positions.

\section{Conclusion}

The two case studies examined in this chapter both use tropes of familiarity and identification in order to articulate the discourse of public heritage. Specifically, the concept of public heritage establishes the terms in which the imagined national community recognizes itself. George A. Reid's pioneer scenes reinforced the latenineteenth-century cult of the pioneer that celebrated pioneer labour as nation-building through intimate, detailed, familial scenes. In this way, pioneer labour was as national as it was paternal. Reid's pioneer scenes offer examples of how the Canadian national story is narrated as a family genealogy. Similarly, the Wychwood Park community mobilized a discourse of inheritance when advocating for the preservation of the Gustav Hahn mural. Park residents argued that it was part of their filial duty to preserve the Hahn mural on the basis that it would benefit Canada's fine arts tradition. Nation-building, according to the affective logics of heritage discourse, is also a family affair. 
Both Reid's paintings and the Hahn mural preservation campaign are examples of efforts to establish and sustain a settler line of cultural succession in Canada. Reid's paintings depicted pioneers as nation-building heroes that viewers were encouraged to identify with as kin. His public murals in City Hall were marketed as opportunities for Toronto to participate in international design trends - a sign of national promise.

Campaigners to preserve the Hahn mural in 1995 similarly argued that future generations would benefit from access to it. In both cases, art advocates warned of national cultural degeneration if public heritage was not pursued. As Marlene Goldman has argued, anxieties about degeneration represent racialized concerns about genealogical pedigree when land ownership is called into question. ${ }^{41}$ Discourses of public heritage, national belonging, and cultural lineage all serve the settler colonial project because they fundamentally legitimize the settler land economy.

Chapter Six explores degeneration and nationalism in greater detail, as I consider the ways that the social construction of whiteness contributes to the third goal of settler colonialism: colonial transcendence.

\footnotetext{
${ }^{41}$ Goldman, DisPossession, 72.
} 


\section{Chapter Six \\ Colonial Transcendence and the Whiteness of Wychwood Park}

Modern society ... from the nineteenth century up to our own day, has been characterized on the one hand by a legislation, a discourse, and organization based on public right, whose principle of articulation is the social body and delegative status of each citizen; and, on the other hand, by a closely linked grid of disciplinary coercions whose purpose is in fact to assure the cohesion of this same social body ... The powers of modern society are exercised through, on the basis of, and by virtue of, this very heterogeneity between a public right of sovereignty and a polymorphous disciplinary mechanism.

Michel Foucault ${ }^{1}$

A "racism of expansion" through which the bourgeoisie authorized itself to impose a normative "health, hygiene, descent, and race" on class others, this dynamic racism found its support in the cultivation of an exemplary racial purity.

Jennifer Henderson ${ }^{2}$

Racializing practices are the foundation of nation-building in Canada, making it necessary to centre the production of whiteness in a study of social and geographical landscapes.

Sheelah McLean ${ }^{3}$

In this final analytic chapter, I continue building my argument that Wychwood

Park is a white settler colonial landscape. Whereas previous chapters situated the Park as settler colonial and landscaped, this chapter focuses on the Park's whiteness. I argue that Wychwood Park can be recognized as a white settler colonial landscape when examined through the lens of what Battell Lowman and Barker call colonial transcendence. Colonial transcendence is achieved when settler societies "fully replace Indigenous sovereignties

\footnotetext{
${ }^{1}$ Michel Foucault, "Two Lectures," quoted in Jennifer Henderson, Settler Feminism and Race Making in Canada (Toronto: University of Toronto Press, 2003), 28.

${ }^{2}$ Henderson, Settler Feminism, 17.

${ }^{3}$ Sheelah McLean, "The Whiteness of Green: Racialization and Environmental Education," The Canadian Geographer 57, no. 3 (2013): 359.
} 
on the land." $" 4$ The ongoing development of settler society, including an expansion of its permanence through the creation of large state apparatuses, signals colonial transcendence. As Battell Lowman and Barker write, "a settler society is created when a newcomer people shift from identifying with distant empires ... to identify primarily with the political constructs, goals, and society in a new homeland." ${ }^{, 5}$ Settler colonialism is imagined to have been transcended when Canadian national identity replaces British colonial identifications. To invest, imagine, identify with, and work to produce a distinctly national future constitutes the labour of transcending the so-called colonial beginning of a context like Canada. This labour is essential to the settler colonial project in Canada, as it disavows the colonial context as a prerequisite for nation-building, and continues to de-legitimize Indigenous land claims, opportunities for reparation, and possibilities for settler-Indigenous reconciliation.

Understanding colonial transcendence demands closer attention into the structure of Canadian settler society and how power is distributed and enacted within its organization. This chapter's opening epigraph from Michel Foucault is an important reminder of how political power is exercised beyond the reach of the formal state. Colonial transcendence can be taken to refer to practices of national sovereignty that move Canada beyond its colonial origins, such as the advent of responsible government, the institution of a national anthem and flag, the repatriation of the constitution, and so on. These governmental and symbolic gestures insist that colonialism is a relic of Canada's past, therefore imagining Canada to have transcended formal colonial rule. However, Foucault's argument that modern society is characterized by public rights in

\footnotetext{
${ }^{4}$ Emma Battell Lowman and Adam J. Barker, Settler Identity and Colonialism in 21st Century Canada (Halifax: Fernwood, 2015), 31.

${ }^{5}$ Battell Lowman and Barker, Settler Identity, 27.
} 
addition to disciplinary coercions invites further consideration into the ways that colonial transcendence is also embedded in informal governmental practices. As Foucault argues, disciplinary coercions function to "assure the cohesion of [the] social body." Pressures to adapt to dominant Anglo cultural traditions, naming practices, and social behaviour can be understood as the kinds of disciplinary coercion that seek to render the social body cohesive in the interests of national development.

As I have previously mentioned, anti-racist scholars have established a robust field of literature that highlights how white Canadians get positioned within the national imagination as normative citizens charged with regulating the bodies and customs of those racialized as "other." Nikolas Rose and Peter Miller argue a similar vision of modern society to Foucault, writing that "central to the possibility of modern forms of government... are the associations formed between entities constituted as 'political' ... and practices of those authorities ... who endeavor to administer the lives of others in the light of conceptions of what is good, healthy, normal, virtuous, efficient, or profitable."7 In other words, the dominant values of settler society, including those that define, police, and monitor qualities associated with legitimate citizenship, form part of a disciplinary apparatus in a modern democratic society. Efforts at disciplining the social body to become a cohesive whole constitute ways that the public is governed beyond formal mechanisms of the traditional state. As Jennifer Henderson has argued, bourgeois initiatives to change the behaviour and lifestyles of those marked as "class others" on the basis of hygiene, descent, race, and health works to fortify a "racism of expansion" that

\footnotetext{
${ }^{6}$ Michel Foucault, "Two Lectures," quoted in Henderson, Settler Feminism, 28.

${ }^{7}$ Nikolas Rose and Peter Miller, "Political Power Beyond the State: Problematics of Government," The British Journal of Sociology 61, no. 1 (2010): 271-303.
} 
promotes ideas of "racial purity." ${ }^{8}$ Colonial transcendence, I argue, is located not only in nationalist cultural practices, but also in the national disciplinary coercive tradition of normalizing white settler citizens as cultural arbiters and social/moral reformers, tasked with reforming those racialized as "other" within the Canadian national project.

There are many component parts of the social, political, and economic tradition that can be recognized as colonial transcendence within the settler state of Canada. This chapter reads colonial transcendence as guiding the mandates of civic organizations to which Wychwood Park residents belonged at the turn of the twentieth century - the height of Toronto's social reform movement. As artists and art patrons, Wychwood Park residents lobbied for the expansion of state-funded art and centralized urban planning to educate and enculturate Toronto working classes - many of whom were non-Anglo immigrants. Wychwood residents participated in urban beautification in order to develop a sophisticated nation of culturally fluent citizens. The expansion of the state through the early part of the twentieth century transcended Canada's colonial origins by establishing conditions for a national future. As the cultural arm of the state was expanded, cultural leaders found new political power as experts, employed to improve the artistic knowledge of working class and non-Anglo immigrant residents. Through this process, Wychwood Park residents and their contemporaries became positioned as ethnically legitimate cultural arbiters - or white - while those they instructed and advised were imagined to be as in need of cultural uplift. Colonial transcendence, in other words, involved not only the invocation of a national future, but also a national future in which some citizens were racially constructed as, to quote Sunera Thobani, "enterprising nationals" while others

\footnotetext{
${ }^{8}$ Henderson, Settler Feminism, 17.
} 
were constructed as outsiders in need of instruction in order to enter the "master narrative" of the nation. ${ }^{9}$

The binary between normative white citizens and nonwhite outsiders played out spatially within the City of Toronto at the turn of the twentieth century. While Wychwood Park residents were designing their own homes and gardens in large treed lots north of the city centre, they were also advising municipal authorities how to improve the lives and housing conditions of working classes in the urban core. While Wychwood residents lived in a Protestant enclave in a nature-like setting, those perceived to need cultural instruction lived in ethnic, overcrowded urban environments.

In this chapter, I argue that Wychwood Park became a white bucolic correlative to the polluted racialized inner city neighbourhoods social reformers were laboring to beautify. Purposefully designed as an exemplary garden suburb, Wychwood Park served as an idealized racial site associated with nation-building cultural refinement so central to colonial transcendence. The racial logics I identify in this chapter function through contrast - racialization and whiteness are co-constituted through their oppositional relationship to each other in the same way garden suburbs are constituted through their opposition to urban cores. I argue that Wychwood Park is a white settler colonial landscape because it was an idealized racial/spatial counterpoint to the inner city neighbourhoods that reformers worked to aestheticize in order to secure a national future.

To make this argument, I build upon the work of scholars who have studied the way space can be both a reflection of, and a participant in, discourses of racialization and power. In particular, the wilderness has been studied as a symbolic space where white

\footnotetext{
${ }^{9}$ Sunera Thobani, Exalted Subjects: Studies in the Making of Race and Nation in Canada (Toronto: University of Toronto Press, 2007), 4.
} 
bodies "become white." 10 Tropes of adventure, survival, discovery, natural disaster, and pioneering have functioned across a variety of genres to link white character development with a capacity to exercise mastery over nature. In the context of Canada's national imaginary, the wilderness has served as a symbol of Canada's beginning. Myths of empty land rendered productive through the labour of rugged male pioneers and lumberjacks promote a story of Canada's founding that disavows the existence of Indigenous societies and land-use systems. European settlers are imagined as inherently social actors in Canada's wilderness myth -the bodies that created Canadian society out of a supposed pre-social landscape. Consequently, critical geographers have studied the wilderness as white space in Canada's national imaginary, arguing that the wilderness myth situates white bodies as agentic, legitimate, and nation-building. Canada's white wilderness has been described as "curiously devoid of difference," "11 meaning a site marked by racial homogeneity. As Andrew Baldwin has argued, nonwhite national actors excluded from Canada's wilderness mythology "re-enter the national narrative through the apparatus of multiculturalism." ${ }^{\prime 12}$ Multiculturalism is the national language that explains the existence of non-Indigenous, nonwhite Canadians. Significantly, multiculturalism is spatialized as urban within the symbology of Canada. Wilderness is constructed as a space of "national

\footnotetext{
${ }^{10}$ Andrew Baldwin, "Wilderness and Tolerance in Flora MacDonald Denison: Towards a Biopolitics of Whiteness," Social and Cultural Geography 11 (2010): 891. See also Brian Braun, "On the Raggedy Edge of Risk: Articulations of Race and Nature," in Race, Nature, and the Politics of Difference, ed. Donald S. Moore, Jake Kosec, and Anand Pandian (Durham, NC: Duke University Press, 2003), 175203; Jake Kosek, "Purity and Pollution: Racial Degradation and Environmental Anxieties" in Liberation Ecologies: Environment, Development and Social Movements, ed. Richard Peet and Michael Watts (London: Routledge, 1996), 125-54.

${ }^{11}$ Baldwin, "Wilderness and Tolerance," 885.

${ }^{12}$ Baldwin, "Wilderness and Tolerance," 885.
} 
genesis" that predates national development, whereas multiculturalism is historically located in a specific set of political events in the latter half of the twentieth century. ${ }^{13}$

In this chapter, I use a theoretical lens developed by Baldwin to examine the racial/spatial dynamics of Wychwood Park in the context of Canadian settler nationalism. Baldwin argues that wilderness and multiculturalism are "contingent moments in a 'white' historical geography that can be found ... at the imagined centre of Canada's national symbolic order." ${ }^{\prime 14}$ Building upon the work of Catriona Sandilands, ${ }^{15}$ Baldwin argues that the power generated by constructing wilderness and multiculturalism as distinct discourses is an inherently white power. Baldwin uses Ghassan Hage's notion of "white governmental power" to explain the discourses that link white spaces of nature/wilderness to urban ethnically diverse space in the Canadian national imagination. ${ }^{16}$ White governmental power is the moral and social authority to "place" or situate people within the "national spatiotemporal narrative." ${ }^{, 17}$ I use Baldwin's framework to argue that the urban beautification programs in which Wychwood Park residents took part constituted efforts to exercise white governmental power, thereby "[assigning] people their place within the nation." 18

White governmental power can operate discursively, casting some national subjects as leaders and others as followers; some who usher in the future of the nation and others who require instruction in order to evolve. In this chapter, I expand Hage's notion of white governmental power to include built environments. Just as some subjects are cast

\footnotetext{
${ }^{13}$ Andrew Baldwin, "The White Geography of Lauren Stewart Harris: Whiteness and the Performative Coupling of Wilderness and Multiculturalism in Canada," Environment and Planning 41 (2009): 529.

${ }^{14}$ Baldwin, "White Geography," 530.

${ }^{15}$ Catriona Sandilands, "Domestic Politics: Multiculturalism, Wilderness, and the Desire for Canada," Space and Culture 4 (1999): 169-86.

${ }^{16}$ Baldwin, "White Geography," 530.

${ }^{17}$ Baldwin, "White Geography," 541.

${ }^{18}$ Baldwin, "White Geography," 541.
} 
as governors and others as governed, some neighbourhoods are marked as respectable and others in need of improvement by discourses of cultural refinement. This chapter explores how efforts to beautify Toronto's downtown positioned Wychwood residents and their contemporaries as experts in aesthetic reform, charged with governing the aesthetic lives of working-class Torontonians in the interests of national development. Urban beautification programs linked bodies, character, and urban location together. White governmental power was exercised in order to civilize people by civilizing their environment. Just as Wychwood residents were positioned as sophisticated in opposition to the philistine residents of downtown, I argue that the Wychwood neighbourhood was a white counterpoint to the racialized inner city.

\section{Social Reform and Imperialism in Early-Twentieth-Century Toronto}

At the turn of the twentieth century, Toronto was suffering from many of the social and environmental problems that afflicted modern cities worldwide. Poor sanitation systems led to high rates of infant mortality, endemic rates of inner-city poverty resulted in overcrowded housing, high rates of infectious bronchial diseases were caused by wood and coal heating systems, and roads and sidewalks were in states of chronic disrepair. Child welfare was an issue of particular concern. Not only were infant mortality rates high, but frequent disease and early adult death left many orphans. It was not unusual to see children and young teenagers peddling small items on the streets or begging for food, 
as compulsory education laws were poorly enforced and families living in poverty relied on children's income. ${ }^{19}$

In the second half of the nineteenth century, Toronto's population grew 700 percent, from a population of 30,775 in 1851 to 208,040 in $1901 .^{20}$ The population of the city quadrupled from 1880 to 1910 alone, and the physical infrastructure was incapable of supporting such accelerated growth. ${ }^{21}$ The inadequacy of Toronto's physical infrastructure and public sanitation is reflected in the repeated outbreaks of disease in the middle of the nineteenth century. Cholera outbreaks took place in $1834,1849,1854$, and 1866. Typhus swept through the city from 1845-1847, and a smallpox epidemic broke out in $1871 .^{22}$ In 1875,30 percent of infants died due to disease, often related to the consumption of unpasteurized milk. ${ }^{23}$ In the absence of adequate water treatment and drainage facilities, household waste was dumped directly into the city's many creeks and waterways. Water pollution was such a concern the Globe newspaper described the public water supply as "drinkable sewage" in an 1882 editorial. $^{24}$

In 1883, Toronto appointed its first Medical Health Officer, Dr. William Canniff. The appointment reflected an expanded role of the state in preventing - not just responding to - public health crises. After decades of following policies of reactive intervention restricted to outbreaks, City Council was ordered by the newly created Provincial Board of Health (est. 1882) to appoint a medical health officer. In his first six

${ }^{19}$ John McCullagh, A Legacy of Caring: A History of the Children's Aid Society of Toronto (Toronto: Dundurn Press, 2002), 18.

${ }^{20}$ Peter Goheen, Victorian Toronto: 1850 to 1900 (Toronto: Committee on Geographical Studies, 1970), 58.

${ }^{21}$ Phillip G. Mackintosh, “"The Development of Higher Urban Life' and the Geographic Imagination: Beauty, Art, and Moral Environmentalism in Toronto, 1900-1920," Journal of Historical Geography 31, no. 4 (2005): 693.

${ }^{22}$ Heather A. MacDougall, “The Genesis of Public Health Reform in Toronto, 1869-1890," Urban History Review 10, no. 3 (February 1982): 2.

${ }^{23}$ McCullagh, Legacy of Caring, 19.

${ }^{24}$ MacDougall, "Genesis of Public Health Reform," 6. 
months in the role, Dr. Canniff led a city-wide survey, going door-to-door inspecting domestic sanitation. The survey became an annual event during his tenure, and established the continuous inspection of both working and living quarters as an accepted staple of public health policy. From its earliest implementation, public health reform in Toronto relied on the inspection of places where people lived in poverty - working-class homes, workplaces, and public sites. Canniff's department established a complaints process for citizens to register complaints of overflowing privies, suspicious well water, and noxious fumes. In 1885, the Toronto Board of Health received eight hundred such complaints. By 1889 , the number had risen to six thousand. ${ }^{25}$ Canniff's surveys both identified target areas of concern and raised awareness about enforced standards of public cleanliness and waste disposal practices. As the role of the state expanded, so did the state's authority to inspect private residences and regulate not just where, but how people lived. In order to ensure sustained public health, the City of Toronto began educating working-class people on how to clean, how to cook, how to organize their homes, and how to raise their children.

Lobbying from well-organized social reformers created the political pressure to expand the role of the state. However, service provision and the labour of reform was enacted from both within and outside of formal state structures. From approximately 1880-1939, a vast network of social and moral reformers became organized to take action to reform society in order to raise the standard of living and create an idealized society. Across the political spectrum, social reformers were active members of labour unions, urban reform organizations, temperance organizations, child welfare agencies, universities, charities, settlement houses, women's groups, and churches. Nearly every

\footnotetext{
${ }^{25}$ MacDougall, "Genesis of Public Health Reform," 5.
} 
sector of urban Canadian society was impacted by the work of social reformers, who created the political pressure to expand the social welfare state, improve the physical infrastructure of cities, reduce homelessness and child mortality, and implement public safety and labour legislation. Nationalism was used to advance reform ideas, particularly when it came to the assimilation of immigrants. In many instances, building up services and improving the lives of the vulnerable were seen to be part of the nation-building project.

Social reformers were deeply invested in child welfare, and relied on the image of the child as a symbol of the nation's future. Reformers argued that by improving schools, housing, and public parks, tomorrow's citizens would be better equipped to prosper and continue nation-building. Improving service provision in immigrant neighbourhoods presented an opportunity for reformers to instill Canadian values in immigrant children, as opposed to adult immigrants thought to be rigidly bound to the cultural practices from their countries of origin. ${ }^{26}$

Middle-class social reformers were central to organizing different initiatives to improve urban life. Bourgeois women played a central role in social and moral reform. The work of feminist historians who have documented the many contributions women made to public life in the nineteenth and early twentieth centuries contests the commonly accepted notion that nineteenth-century society relegated women exclusively to the domestic sphere. ${ }^{27}$ As Philip Mackintosh has argued, the association of women with

\footnotetext{
${ }^{26}$ For a broader discussion on approaches to immigrant children by leaders of the settlement house movement, see Linda Tomko, Dancing Class: Gender, Ethnicity, and Social Divides in American Dance 1890-1920 (Bloomington: Indiana University Press, 1999), 84.

${ }^{27}$ See in particular Mariana Valverde, The Age of Light, Soap, and Water: Moral Reform in English Canada 1885-1925 (Toronto: University of Toronto Press, 2008); Christine Stansell, City of Women: Sex and Class in New York 1780-1860 (Chicago: University of Illinois Press, 1987); Amanda Vickery, "Golden Age to Separate Spheres? A Review of the Categories and Chronology of English Women's History,"
} 
domestic authority was used to advocate for their public role in urban reform at the turn of the twentieth century. In particular, he writes that "women considered themselves the premier 'housekeepers' of society ... certain bourgeois Protestant women instituted an agenda to maintain the city according to standards of 'home-likeness. ",28

In order to maintain the city as one would a proper household, bourgeois women "investigated various aspects of life in the city from street reform to social hygiene. At the heart of this method is scrutiny. Vigilant perspicacity allows women to observe and attempt to solve social injuries such as incivility, by-law infractions, tenement squalor, lack of infrastructure ... treated with the same poultice: liberal evangelical middle-class homelike values with their emphasis on moral-aesthetic probity." ${ }^{29}$ Public education campaigns on proper domestic cleanliness, as well as the inspections of working-class housing, sidewalks, and neighbourhood parks became part of the scrutinizing purview of bourgeois women.

Inspecting the spaces in which poor and working-class people lived their lives served a double purpose. First, it identified areas of concern within the urban waste disposal, water sanitation, and public infrastructure systems. Second, it enabled social and moral reformers to attempt to "regenerate society and the human soul" by "raising the moral tone" of Canadian society, allowing marginalized populations to adopt "purity

The Historical Journal 36 (1993): 383-414; Ann Douglas, The Feminization of American Culture (New York: Avon Books, 1978); Nancy Hardesty, Women Called to Witness: Evangelical Feminism in The Nineteenth Century (Nashville: Abingdon Press, 1984); Mary Ryan, Women in Public (Baltimore: Johns Hopkins University Press, 1990); Mary Ryan, "Gender and Public Access: Women's Politics in Nineteenth-Century America," in Habermas and the Public Sphere, ed. Craig Calhoun (Cambridge MA: MIT Press, 1992): 259-88.

${ }^{28}$ Phillip G. Mackintosh, "Imagination and the Modern City: Reform and the Urban Geography of Toronto, 1890-1929” (PhD thesis, Queens University, 2001), 75.

${ }^{29}$ Mackintosh, "Imagination", 128. 
ideals fitting to this 'age of light and water and soap. ${ }^{\prime 30}$ Cleanliness and moral fortitude became synonymous with each other for turn-of-the-twentieth-century reformers. A clean city was morally strong, and a pure population less sinful. Metaphors of cleanliness extended into notions of sexual morality and racial legitimacy. By engaging in initiatives to reform - and sanitize - the lives of working-class and nonwhite residents, white bourgeois women simultaneously asserted a role for themselves in the public sphere wherein their race and class status marked them as fit citizens despite limited formal citizenship on the basis of sex. Alongside metaphors of domestic cleanliness, ideas about "racial purity" and "national purity" became articulated as goals of social and moral reform. $^{31}$

One of the most concerning neighbourhoods in Toronto from a public health perspective was the St. John's Ward. The St. John's Ward was formerly "Macaulaytown," the Town of York's first suburb, later to become Toronto's inner-city slum, a large cluster of makeshift houses bordered by Queen Street to the south and College Street to the north, between Yonge Street and University Avenue. Throughout the nineteenth century, it was a densely populated working-class neighbourhood, situated within walking distance of both commercial and later industrial districts, as well as the Toronto harbour and Union Railway Station. At the end of the nineteenth century, it was known for being a distinctly immigrant neighbourhood. Jewish, Chinese, and Italian immigrants lived, worked, and operated small businesses in what became known colloquially as "The Ward." The Ward caught the attention of many social reformers. All the social and environmental problems of the nineteenth century were especially true for residents of The Ward: large families

\footnotetext{
${ }^{30}$ Valverde, Age of Light, Soap, and Water, 17

${ }^{31}$ Valverde, Age of Light, Soap, and Water, 32.
} 
lived in shacks, some of which were not even located on proper streets but instead in the backyards of other houses. Named "rear cottages," they were described by the Mail and Empire as "a menace to the Public and a Grave Source of Danger." 32 The neighbourhood as a whole was described in 1906 as "an open sore from which flow fetid currents which cannot but be corrupting the whole community. ${ }^{, 33}$ While this characterization of The Ward attests to the public health risks posed to all by its reputation as a dangerously polluted place to live, the so-called corrupting currents emanating from The Ward can also be interpreted to reference its status as a racially backwards place within the city.

At the turn of the twentieth century, racist anxieties were being expressed that the Anglo-Saxon character of Toronto was changing due to non-English-speaking immigrants making up 35 percent of the city's population. Walking through The Ward, one could expect to see "throngs of Chinamen lounging in the streets and doorways," as one reporter warned, suggesting these throngs were signs of "the awful menace lurking behind the partitions or screens of some of these innocent appearing laundries." ${ }^{34}$ The filth of city streets went almost unnoticed by the "black-bearded men with sacks of rags on their shoulders and olive-skinned hawkers of ice cream [that] pervade the streets, women with earrings and round brown arms stand in the doorways, and rollicking children, with sunkissed cheeks, and eyes shaded by long dark lashes, take their pleasure in the dust of the sidewalk or the gutter. ${ }^{35}$ Finally, any hope at assimilation would be lost, particularly on the "[Italian] women, shut within their little homes, [who] are slow to learn either the

${ }^{32}$ Quoted in Mackintosh, "Development of Higher Urban Life," 695.

${ }^{33}$ Toronto Daily News editorial, quoted in Sean Purdy, "Housing Reform Thought in English Canada, 1900-1950," Urban History Review 25, no. 2 (1997): 31.

${ }^{34}$ Jack Canuck (biweekly newspaper) in 1911, quoted in Arlene Chan, "Against All Odds: The Chinese Laundry," in The Ward: The Life and Loss of Toronto's First Immigrant Neighbourhood, ed. John Lorinc, Michael McLellan, and Ellen Scheinberg (Toronto: Coach House Books, 2015), 40-1.

${ }^{35}$ Emily Weaver, "The Italians in Toronto," in Lorinc, McLellan, and Scheinberg, The Ward, 102. 
language or the customs of their adopted country, and do not readily take advantage of organizations intended for their benefit. Their husbands, mixing with workpeople of other nationalities, are less inaccessible to such influences than the women, but of course it is the children with whom the process of assimilation is most rapid and effective." 36

The future prime minister, Mackenzie King, stated in 1897 that "the foreigners, more particularly those in unfortunate circumstances, have shown a decided tendency to group themselves in small colonies, and in this condition they keep up the old life to which they were accustomed $\ldots$ and have as their prime object in life the eking out of a mere existence. ${ }^{, 37}$ King's observation reflects a belief that immigrants were selfsegregating into small "colonies," unwilling to integrate into dominant settler customs. Not only were immigrants considered incapable of integration, their tight-knit communities posed a so-called "menace in our civilization unless [they learn] to assimilate the moral and religious ideals of citizenship." ${ }^{\prime 38}$ The Ward, in other words, was not only polluted, poorly constructed, and dangerous for children, its residents were national outsiders, resistant to assimilation, an impediment to national prosperity, and in need of moral and cultural instruction. Teaching immigrant children how to adopt the values of Anglo social reformers was an example of colonial transcendence, because the moral and cultural instruction at stake was fundamentally organized in the service of building a Canadian nation.

To well-educated, socially minded progressives at the turn of the twentieth century, the physical space of the inner city was chaotic, filthy, and promoted disease. Racist attitudes about non-Anglo immigration and environmental anxieties about the

\footnotetext{
${ }^{36}$ The Globe, July 16, 1910, quoted in Weaver, "Italians in Toronto," 10.

${ }^{37}$ Mackintosh, "Development of Higher Urban Life," 694.

${ }^{38}$ Quoted in Mackintosh, "Development of Higher Urban Life," 694.
} 
rapidly deteriorating infrastructure and public health risks were expressed interchangeably. Consider this report from William Struthers in 1913, arguing for public health inspections in schools: "Poor housing conditions, lack of light and ventilation, uncleanliness, ignorance of proper care of the body and of the laws of health, unwholesome and improper food and drink, the prevalence of venereal and other diseases are rapidly producing a degenerate race. ${ }^{39}$

Here, racial degeneration is attributed not only to poor housing and diet, but also a kind of "ignorance" with regards to personal hygiene that, left uncorrected, will lead to communicable disease. The author implies that improving housing conditions and hygiene, as well as educating those living in poverty, will produce a more civilized citizenry. The modern racism cultivated by reformers such as Struthers promoted a racial logic that suggested that model citizens could be created through social reform. Because those racialized as nonwhite were situated as those in need of instruction within this logic, many have argued that the social reform movement was a form of social imperialism. ${ }^{40}$

In the midst of rapid social, cultural, environmental, and industrial change, the Anglo-Saxon elite of Toronto was working to sustain and intensify its cultural supremacy. ${ }^{41}$ Two related schools of thought debated the direction the governing elite should take towards improving public sanitation while also establishing Anglo-Saxon dominance. Eugenicists argued for creating an ideal society by breeding idealized citizens, forcibly sterilizing those deemed unfit for citizenship. Euthenicists, on the other

\footnotetext{
${ }^{39}$ William Struthers, "The Point of View in Medical Inspection of Schools," quoted in Purdy, "Housing Reform," 34.

${ }^{40}$ Purdy, "Housing Reform," 34. Sidney Jacobs, "Race, Empire, and the Welfare State: Council Housing and Racism," Critical Social Policy 5, no. 13 (1985): 6-28.

${ }^{41}$ Carol Bacchi, "Race Regeneration and Social Purity: A Study of the Social Attitudes of Canada's English-Speaking Suffragists," in Interpreting Canada's Past: Volume II, After Confederation, 2nd ed., ed. J.M. Bumstead (Toronto: Oxford University Press, 1993), 249.
} 
hand, argued that the environment, rather than the genepool, was responsible for social misfortune. Improve the environment, claimed euthenicists, and a society could improve its citizens. Euthenics ideas were also reflected in the social-aesthetic philosophies central to the Arts and Crafts Movement - that good societies produced good quality design. For Arts and Crafts Movement proponents like George Reid and Eden Smith, improving design standards necessarily benefited society.

While it is true that bourgeois women played significant roles in the social/political reform movements, these roles were nonetheless circumscribed by patriarchal ideas about gender. Often organizing within women's societies, formal power was nevertheless exclusively held by men in municipal, provincial, and federal levels of government. Similarly, in the Arts and Crafts Movement and the urban beautification movements that it informed, women actively participated in initiatives in which men held formal leadership roles. Just as women interested in urban reform argued for their public role under the auspices of "municipal housekeeping," women interested in art and design situated their aesthetic interest as inherently ladylike. As a late-nineteenth-century essay opined, "Why should not the instinctive taste and natural grace of woman be reflected in the hues and harmonies of colour and form on the walls of her rooms?"42 Engaging in art production and appreciation allowed bourgeois women at the turn of the twentieth century to "be beautifiers, civilizers, orderers in the face of the social mobility and economic instability of a chaotic and threatening world. ${ }^{43}$ To that end, reformer women engaged in a variety of artistic initiatives directed towards beautifying urban environments and in

\footnotetext{
42 "Art-work for women I," Art Journal (1872), 66, quoted in Anthea Callen, "Sexual Division of Labor in The Arts and Crafts Movement," Woman's Art Journal 5, no. 2 (1984): 2.

${ }^{43}$ Griselda Pollock and Rozsika Parker, Old Mistresses: Women, Art and Ideology (New York: Pandora Press, 1981), quoted in Callen, "Sexual Division," 2.
} 
turn civilizing the Canadian populace, but their efforts were considered secondary to that of men, particularly when formal government support was concerned.

While there is evidence of some Wychwood Park resident women being active in the arts - such as Ellen Hahn, Mary Hiester Reid, and Mary Wrinch (later Mary Wrinch Reid) - the archive of their participation is limited to their roles as artistic producers. All three women had active artistic practices. However, there is little information about their access to civic organizations in which public advocacy was undertaken. The male residents of Wychwood Park had access to greater amounts of institutional power and public acclaim. In particular, George Reid, Gustav Hahn, and Eden Smith were active in a series of projects that sought to beautify Toronto in the interests of building a national future. I argue that these initiatives formed an effort to transcend Canada's colonial context, and regulate the lives and racial purity of downtown non-Anglo residents.

Three initiatives that illustrate Wychwood Park residents' engagement with urban beautification are the Toronto Guild of Civic Art, the Toronto School Art Leagues, and the Toronto Housing Company. Each organization was led by a coalition of citizens, with future Wychwood residents in key leadership roles. These organizations were started simultaneous to the wave of artists moving into the Park, and serve as an important reminder of how residents like Reid, Hahn, and Smith, in particular, were already working together in a series of collaborations as they planned their move to Wychwood Park. Their collaborations in the Toronto Guild of Civic Art, Toronto School Art Leagues, and the Toronto Housing Company demonstrate their commitment to social reform through environmental beautification, working-class edification, national development, and, by extension, colonial transcendence. 


\section{Toronto Guild of Civic Art}

The Toronto Guild of Civic Art (TGCA, or "the Guild") was established in 1897, ten years before residential development intensified in Wychwood Park. Many future Park residents were active in the Guild, such as George Reid, Mary Hiester Reid, Gustav Hahn, Eden Smith, E. A. Duvernet, George Howell, and Marmaduke Matthews. The TGCA was formed as an advisory body to the City of Toronto on matters related to art, urban planning, and heritage preservation. Guild members considered Toronto's social problems to be directly related to its physical design. Further, Guild members believed that the key to building a world-class city was in investing in urban planning, public parks, and public art. The TGCA advised City Council on how to beautify Toronto with its mandate to "promote and encourage civic art, including mural painting and decoration, sculptures, fountains and other structures or works of art or of an artistic character." ${ }^{44}$ The TGCA offered an opportunity for art workers and patrons to participate in the social reform movement. Motivated by the same concerns about urban sanitation and immigrant assimilation, Guild members argued that beautifying urban neighbourhoods would produce a more sophisticated citizenry. In this way, proponents of public art and urban beautification argued that beautiful environments could play a civilizing role for the masses, rather than an exclusive pastime for the elite.

Guild members argued that public investment in urban beautification was essential to building a national future. For this reason, the TGCA is an example of how Wychwood Park residents participated in the settler colonial project of transcendence. Not only did the TGCA lead initiatives premised on the logic that nonwhite working class residents

\footnotetext{
${ }^{44}$ Civic Guild Minutes 1897-1914, May 21, 1897. Civic Guild of Toronto Papers, S48, Baldwin Room, Toronto Reference Library.
} 
required civilizing environments, but these initiatives were promoted in order to ensure Canada's national future. Further, both the activities of the TGCA and the political logics that motivated them mobilized space - land use and environmental design - as a civilizing agent and nation-building tool. Settler colonial ways of knowing underscored the values and practices of the TGCA.

Canada's progress was considered by Guild members to be a reflection of the standards of public taste. By this logic, a learned art public would be a sign of a learned society. Put another way, those who lacked artistic knowledge and savvy were impeding national development. An example of this reasoning can be found in the remarks delivered in May 1899, when Byron Edmund Walker, then-President of the TGCA, formally presented two pioneer murals to the City of Toronto on behalf of the TGCA. George Reid had painted the murals for free in an effort to stimulate government support for a broader mural scheme proposed by the TGCA for the newly constructed City Hall. In his address, Walker stated that the Guild hoped that the murals would complete the building, and "help in the creation and maintenance of a refined and artistic taste in those who from time to time look at them." ${ }^{45}$ Walker's comments highlight the so-called "transcendent" 46 capacity of art - as though physical proximity to art would stimulate refined taste among Torontonians who otherwise lacked access to art.

As discussed in Chapter Five, the murals had been initially proposed to "guard against inadequate interior decoration and initiate a scheme to emulate the notable

${ }^{45}$ Civic Guild Minutes 1897-1914, May 16, 1899. Emphasis mine.

${ }^{46}$ See Phillip G. Mackintosh, "The Occult Relation Between Man and the Vegetable: Transcendentalism, Immigrants, and Park Planning in Toronto, circa 1900," in Rethinking the Great White North: Race, Nature, and the Historical Geographies of Whiteness in Canada, ed. Andrew Baldwin, Laura Cameron, and Audrey Kobayashi (Vancouver: UBC Press, 2011), 85-106 for further discussions about transcendentalism and the imagined geographies of urban reformers at the turn of the twentieth century in Toronto. 
examples of decoration in public buildings in the UK, France, the United States, and others. ${ }^{\prime 47}$ Therefore, murals would enable Toronto to participate in an international standard for public building decoration. By initiating a mural scheme, the TGCA hoped to elevate Toronto's artistic status, an advancement that some dreamed could render the city the "Ravenna of the future." 48 Access to public art served two related goals: first, to offer a civilizing influence to the public at large, and second, to ensure Toronto kept apace of international design trends, thereby ensuring its futurity as a world-class city.

Members of the Guild believed the City needed advisement on urban beautification, because Council did not appear to prioritize urban planning to the extent that was required. As the Lieutenant Governor of Ontario, Mortimer Clark, said during his speech at a Guild event, "there was a change coming over the Western World, and more beautiful surroundings were demanded by its people, even the medical men now objecting to ugly environments. The undercrust of the United States was becoming educated and reaching to higher ideals, and unless the people of Toronto waked up they would soon be left behind." ${ }^{, 49}$ Clark's comments are an important reminder of beautification's double purpose: urban beautification rendered a city both healthier (as evidenced by his nod to "medical men"), and assisted the "undercrust" in "reaching higher ideals." Making Toronto more beautiful was important, not only because it would make the City a more livable place to call home, but also because it would be a sign of Canada's progress in cultivating worthy citizens.

\footnotetext{
${ }^{47}$ Letter to E.J. Lennox, quoted in Charles C. Hill, "For an Integration of the Arts," in Artists, Artisans, \& Architects: Canadian Art 1890-1918, ed. Charles C. Hill (Ottawa: National Gallery of Canada, 2013), 136-7.

48 James Mavor, quoted in Charles C. Hill, "For an Integration of the Arts,"137.

49 "Boomed Scheme to Improve City: Prominent Men Endorse Guild of Civic Art. Ontario Architects Dine. Hon. Mortimer Clark, Mayor Coatsworth and Prominent Financiers Speak at National Club," Mail and Empire, January 17, 1906. Civic Guild Minutes 1897-1914.
} 
The largest-scale intervention made by the TGCA was the Report on a Comprehensive Plan for Systematic Civic Improvements in Toronto, submitted to City Council in 1909. The TGCA hired Sir Aston Webb, a British architect and urban planner, to design an urban plan for Toronto that would create a plan for increased green space throughout the city. The impulse to add parks to Toronto's cityscape was informed by contemporaneous trends in urban beautification that began with the White City exhibit at the Chicago World's Fair in 1893. At the turn of the twentieth century, urban reformers were "tired of polluted air and water, dirty streets, grimy buildings and disordered cities. From the White City ... the lesson has been impressed that ugliness and inconvenience for the present and the future will yield to the magic power of the comprehensive plan." ${ }^{50}$

Webb's Plan of 1909 proposed the addition of hundreds of acres of green space around the city, including a ring of parks, parkways, and playgrounds. The added green space was thought to have the potential to "directly reshape ... the working class (for want of a better term)." ${ }^{51}$ As Philip Mackintosh has argued, the Plan of 1909 proposed park space to be purposefully placed in immigrant neighbourhoods, in order to play a "racially sanitizing" function. ${ }^{52}$ Nature, like art, was imagined to have a civilizing effect on the masses, particularly those who lived in overcrowded slums filled "scores of ragged children, 'rolled in dust' and [who] shot craps in the shadeless, stifling, dirt lanes." 53 The exposure of children in particular to nature was considered to be "essential ... [to] their

\footnotetext{
${ }^{50}$ Charles Zueblin, A Decade of Civic Development (Chicago: University of Chicago Press, 1905), 82, quoted in Mackintosh, "Occult Relation,” 88.

${ }^{51}$ Mackintosh, "The Development of Higher Urban Life," 693. Also in Mackintosh, "Occult Relation," 95.

52 Mackintosh, "Occult Relation," 105.

${ }^{53}$ Mackintosh "Occult Relation," 102.
} 
moral training," ${ }^{, 54}$ and had the capacity to transform immigrants "into a 'higher' form of citizen." 55

\section{Toronto School Art Leagues}

At the turn of the twentieth century, there was concern that "the diminishing birth rate in some sections of our population" was causing "the best strains in our country [to go] extinct." ${ }^{, 56}$ Consequently, some argued that "if men and women were taught to be chaste, clean living and high thinking, there would be an uplifting of the race without any special legislation." 57 The Toronto School Art Leagues (TSAL) were part of an initiative to teach "high thinking" and thereby create a "higher" form of citizen.

Established in 1896 by upper-class women in the affluent suburb of Rosedale, what began as the Ladies League for School Art grew within two years to become the TSAL. The TSAL recognized that "in every civilised person there is a craving for beauty, though that craving is often perverted." ${ }^{, 58}$ In order to nurture the craving for beauty, and ensure it was "in good keeping with established canons of good taste," 59 the TSAL partnered with the Ontario Society of Artists and the TGCA to form an advisory board that worked towards a province-wide mandate for bringing art and artistic education into public schools. George Reid played a leading role in organizing the governance structure of the TSAL, which stipulated that equal numbers of government officials, members of

\footnotetext{
${ }^{54}$ Toronto Daily Star, 1912. Quoted in Mackintosh “Occult Relation,” 95.

${ }^{55}$ Mackintosh "Occult Relation," 86.

${ }^{56}$ Bacchi, "Race Regeneration," 239.

${ }^{57}$ Bacchi, "Race Regeneration," 241.

${ }^{58}$ J.H. Hughes and E. Foster, eds., The Dominion Educator, 8 volumes (Toronto: Peace Edition, 1919), 1325. Quoted in Mackintosh "Development of Higher Urban Life," 700.

${ }^{59}$ School Art Leagues Movement, Canadian Architect and Builder 2 (February 1900), 24, quoted in Mackintosh "Development of Higher Urban Life," 701.
} 
the lay public, artists, and architects be represented on the board. The first artists to sit on the board were George Reid, Gustav Hahn, and Eden Smith, all of whom were neighbours in the High Park neighbourhood, and all of whom would move to Wychwood Park within a decade.

The TSAL reflected Arts and Crafts Movement leader John Ruskin's declaration that to "teach taste is to form character." ${ }^{, 60}$ Not surprisingly, the 1899 Toronto School Art League pamphlet stated so explicitly, advertising that "it is ... of the highest importance that [a child's] environment be of the best possible character, so that his life may be filled with the centres of truest intellectual and spiritual growth at maturity ... It is therefore one of the clearest duties of the schools to qualify all children for the correct interpretation of Literature, Music, and Art, that they may be able to enrich and ennoble their lives from these stories of culture and power." ${ }^{\prime 61}$ The TSAL implemented programs to facilitate art education, and organized schemes whereby the government would buy art for permanent display in schools and facilitate a process through which TSAL board members would advise the government on the architectural design and decoration of public school buildings. Advising the government on architectural design was informed by the desire to "make school buildings, by attention to their design, a means of education in themselves." ${ }^{.62}$ The TSAL positioned its movement as an extension of the social reform movement, arguing that, in the spirit of the Boston School Art League, "art and hygiene were one. ${ }^{93}$ Clean environments were beautiful environments, and the impulse to beautify schools with the fine arts was synonymous with efforts to correct sanitation

\footnotetext{
${ }^{60}$ E. Lisa Panayotidis, "The Complexity of 'Seeing' and Doing 'Good': A Canadian Art Education Analysis of the 'Good Society,"' Canadian Review of Art Education 29, no. 2 (2002): 3.

${ }^{61}$ School Art Leagues, Circular, 1899 (Toronto: Toronto School Art Leagues), 3-4. Emphasis mine.

${ }^{62}$ Mackintosh "Development of Higher Urban Life," 701.

${ }^{63}$ School Art Leagues, Circular, 1899, 7.
} 
systems in the urban core. As Philip Mackintosh points out, "school art leagues hoped to use the aestheticized geography of the public school to remake the moral lives of philistine ... school children ... [P]ut children close to beauty and art and the latter will produce moral effects in those children." ${ }^{64}$

The Toronto School Art League was a reflection of nation-building aspirations. Of the many goals laid out by the League, a central goal was to "stimulate as far as possible an interest in good art, ${ }^{, 65}$ thereby improving the artistic fluency of Toronto schoolchildren. By educating children on proper art and the standards of taste, social reformers hoped to contribute to the development of the Canadian nation. Cultural anxieties about Canada's capacity for producing good artists abounded in the late nineteenth century. Jean Grant, art critic for Saturday Night, wrote in 1898: "We are not an artistic nation; not a nation of painters or sculptors or dramatists, and never will be as long as the artistic faculties receive so little attention in the education of the young." Offering artistic education was considered to be part of an overall effort to raise Canada's cultural prestige and national reputation. Indeed, understanding how to read and interpret Western art was considered a characteristic of good citizenship. ${ }^{67}$

To that end, the Toronto School Art League functioned not only to expose schoolchildren to art, but specifically to curate their art education. Included in the Toronto Art League circular is a "list of photographs, prints, and casts suitable for school-room decoration. ${ }^{, 68}$ The list is organized according to national school of painting, with the

\footnotetext{
${ }^{64}$ Mackintosh, "Development of Higher Urban Life," 713.

${ }^{65}$ Advisory Board of the Toronto School Art Leagues, School Art Leagues (Toronto: Warwick Brothers \& Rutter, 1899), 3. RG 2-42-0-322, MS 5611, Archives of Ontario.

${ }^{66}$ Quoted in Mackintosh, "Development of Higher Urban Life," 700.

${ }^{67}$ Mackintosh "Development of Higher Urban Life," 700-1.

${ }^{68}$ Advisory Board of the Toronto School Art Leagues, School Art Leagues, 10-13.
} 
highest representation of Italian and French painting, followed by prints from the English and American schools, with limited offerings from the Flemish, Dutch, German, and Spanish schools. Therefore, the TSAL worked to instill in Torontonian schoolchildren a knowledge of, and appreciation for, European art. European art education was one way that Toronto residents could boast a metropolitan level of cultural refinement, thereby transcending the limits of their colonial locale. Standards of taste and fluency in art were metrics that social reformers used to measure Toronto's national potential.

\section{Toronto Housing Company}

As I have highlighted, social reformers articulated the importance of beautiful and enriching environments as essential to a racially pure, national future. The stronger the national future, the more colonialism would be fully transcended and symbolically relegated to the past. In the interests of building a healthy nation, environmental modifications were often justified on the basis that they would improve public health. Housing was a significant sector of public health policy. As Dr. Charles Hastings, the Toronto Medical Officer of Health (MOH) from 1910-1929, asserted in a speech to the Calgary City Planning Commission in 1912, "The future of our Empire, the future of our race depends upon the preservation of ... the individual home, the individual family, the individual brought up in home, and the association of home life - upon that all our success depends. ${ }^{.69}$

To that end, Hastings implemented teams of female "sanitary inspectors" who would visit immigrant houses and "teach them how to clean up and keep clean their

\footnotetext{
${ }^{69}$ Charles Hastings, "Town Planning and Housing," speech delivered to the Calgary City Planning Commission, 1912, quoted in Sean Purdy, "Housing Reform," 34.
} 
homes and environments," because "many of these people, by reason of birth and environments, have neither the moral stamina or the intellect to rid themselves of their vices and shortcomings. ${ }^{, 70}$ White governmental power functioned to construct immigrant residents as incapable of governing themselves, while reinforcing the idea that white Anglo reformers had the expertise and authority to inspect immigrant households and offer instruction on sanitation, home decoration, and domestic design. Immigrant domestic space was rendered public through state-ordered inspections, as well as through the reports issued to City Council on behalf of the $\mathrm{MOH}$, which included photographic documentation of slum living conditions.

Following the $1911 \mathrm{MOH}$ report that included photographs of Toronto slums, reformers quickly sprang into action and formed a committee comprised of members from City Council, the TGCA, the Manufacturer's Association, and the Board of Trade to study the issue of housing accessibility and sanitation. On the committee's recommendation, the Toronto Housing Company (THC) was formed for the purpose of building clean affordable housing for working-class families in the city.

Social reformers believed that slum housing bred criminal activity and disease. The moral case for affordable housing relied on the argument that well-designed neighbourhoods could lower rates of crime and disease. Housing reformers appealed to a sense of progressive (colonially transcendent) nationalism by advocating for affordable housing on the basis that old world problems should be circumvented in the new world. For example, the 1911 Report of the Chief Medical Officer cautioned, "What we have read of with disgust as having happened in the cities of Europe in the Middle Ages,

\footnotetext{
${ }^{70}$ Charles Hastings, "The Modern Conception of Public Health Administration," COL, October 1917, 8990, quoted in Purdy, "Housing Reform," 35.
} 
happens in Toronto now before our eyes." ${ }^{71}$ Two years later, the first report issued by the THC echoed the Chief Medical Officer's lament, stating, "it will be a lasting discredit to Canada if we permit the reproduction here of evils from which the countries of the old world are suffering." ${ }^{72}$ The campaign to create clean affordable housing was constructed as a campaign to secure a moral and prosperous future for Toronto and for Canada. To allow slum conditions to spread would not only bring Toronto back in time to medieval living conditions, but it would also reproduce problems already plaguing industrialized countries. The moral case for supporting housing reform appealed to a shared imagined future for Canada that saw national development as an opportunity to transcend its colonial status and the economic limitations of the old world.

Progressive settler futurity was imagined as a chance to improve upon the living standards of other industrialized cities. Within the discourse used by affordable housing advocates, the physical space of Canada was imagined as a potentially formative conduit for the creation of a model citizenry. Of immigrants, the first report of the THC wrote, "People of all countries ... are not different from ourselves, except in the lesser opportunities they have had for the development of mind and soul ... Given the right environment, with the advantages of education, they will become true and valuable Canadians. ${ }^{.73}$ For full human potential to be reached, in the imagination of social reformers, social programs needed to be developed in concert with proper environments.

The THC oversaw the construction of the Spruce Court and Riverdale Court housing developments (now known as the Bain Co-op). Spruce Court and Riverdale

\footnotetext{
${ }^{71}$ Geoffrey Simmins, "Competing Visions for Redesigning the Canadian City," in Hill, Artists, Artisans, \& Architects, 256.

${ }^{72}$ Better Housing in Canada: The Ontario Plan. First Annual Report of the THC, Ltd., 1913, 12. Toronto Housing Company Fonds 1018, Box 146637, File 3, City of Toronto Archives.

${ }^{73}$ Better Housing in Canada, 14-15.
} 
Court are examples of housing projects designed to provide beautifully designed, structurally sound housing for economically marginalized families in the early twentieth century. Eden Smith was chosen as the architect to design the housing projects. Smith moved into Wychwood Park in 1912, the same year reformers organized to form Spruce Court and Riverdale Court. Smith's design of the housing project occurred simultaneous to his active contributions towards creating Wychwood Park. Spruce Court and Riverdale Court embody many of the same design principles adopted in the Park, on a smaller scale.

The Spruce Court and Riverdale Court housing developments were formal responses to Toronto's housing crisis, and represented what many social reformers hoped would be the first step of many in radically changing working-class housing across the city. The design of Spruce and Riverdale Courts reflects a vision for Toronto as a city of homes, rather than tenements (apartment buildings). As the Toronto Board of Health wrote in 1918, "When New York City was the size of Toronto she had no tenements and consequently no tenement evils. Therefore, let us build so as to make Toronto a City of individual homes." ${ }^{, 74}$ Tenements were imagined to be sites of social and physical disease in the minds of reformers. Many tenements were argued to contain higher rates of tuberculosis, and to be fit only for young married couples without children. Building places unfit for children was considered akin to "race suicide ... [tenement housing] favors the development of social problems and physical problems." ${ }^{75}$ Tenement housing was a dangerous prospect for Toronto's urbanscape not only because residential density bred disease, but also because tenements did not offer sufficient green space to the residents who lived there. As Dr. Hastings stated in his $\mathrm{MOH}$ report, "Children that are

\footnotetext{
${ }^{74}$ Report of the Medical Officer of Health on Housing, 1918. Toronto Housing Company Fonds 1018, Box 146637, File 2, City of Toronto Archives.

${ }^{75}$ Report of the Medical Officer of Health on Housing, 1918.
} 
too far removed from Nature, are likely to be too far removed from Nature's God.

Furthermore, the raising of children in such environments escape the numerous temptations of congested slum surroundings and make good citizens."76 The proper cultivation of citizens required low-density housing with access to green space.

Social reformers believed that insisting upon the construction of homes rather than tenements would ensure Toronto's ability to circumvent the social and public health problems that overwhelmed larger centres like New York. Housing reform was as much about the prevention of future problems as it was the management of contemporaneous ones. As the MOH report stated, "There is no more sacred word in the English language than 'home' and on the retaining of the sacredness and significance of our homes depends the future of our municipality and our Nation ... to this end the construction of tenement houses should not be permitted." 77 Building single-family houses was understood as an architectural contribution to building the nation.

To actualize the ambitions of housing reformers, Wychwood Park architect Eden Smith designed "cottage flats." Not to be confused with tenements, a cottage flat is "a modern apartment with its own front door to the street."78 The design of Spruce Court and Riverdale Court organized buildings around grass courtyards, intended to be used as play areas for children. By designing apartments each equipped with a front door facing a grassy court area, "small children will have ample room to play, where their parents can see them, and away from the dangers and dust of the street." ${ }^{, 79}$ Therefore, the environment of the home was built into the city environment in a way that minimized exposure to filth

\footnotetext{
${ }^{76}$ Report of the Medical Officer of Health on Housing, 1918.

${ }^{77}$ Report of the Medical Officer of Health on Housing, 1918.

${ }^{78}$ Cottage Flats at Riverdale Courts, 1920, 10. Toronto Housing Company Fonds 1018, Box 146637, File 4, City of Toronto Archives.

${ }^{79}$ Cottage Flats at Riverdale Courts, 1920, 10.
} 
and danger. Spruce Court and Riverdale Court boasted modern heat and hot water, eliminating the use of wood stoves, and the THC declared proudly that "there are no dark or poorly ventilated rooms. ${ }^{, 80}$ Eden Smith was designing Spruce and Riverdale Courts in the same years that he was designing a significant number of houses in Wychwood Park. The spatial values reflected in the THC developments were actualized on a grander scale in Wychwood Park.

In line with the moral-aesthetic vision that guided the development of Spruce Court and Riverdale Court, Smith incorporated Arts and Crafts architectural details in the design of the buildings. Smith used brick for the first storey of the cottage flat complexes, with half-timbering and stucco adorning the second storeys. Gable roofs cited the Arts and Crafts Movement's promotion of Gothic design features.

The landscape of Spruce and Riverdale Courts ensured that families had access to green space, considered to be a fortifying influence on young children. By providing working families with adequate housing, reformers hoped to be building Canada's national capacity by cultivating future citizens. As the THC stated in their first annual report in 1913, "A better environment, better houses, better education and some human help can make of their children, sturdy, worthy citizens." ${ }^{~} 1$

The cultivation of citizens through environmental reform strengthened the permanence of settler society. Urban reformers were responding to crises in public health and infrastructural decay, but they were responding with the future in mind. The imagined future was premised on the transcendence of Indigenous sovereignty, in order to continue building the existing settler society and strengthen Canada as a whole. In order to build an

${ }^{80}$ Cottage Flats at Riverdale Courts, 1920, 10.

${ }^{81}$ Better Housing in Canada, 15. 
idealized society, urban reformers advocated for the integration of idealized design in city spaces. Wychwood Park residents contributed to the movement to beautify Toronto by forming the Toronto Guild of Civic Art, contributing to the Toronto School Art League, and designing Spruce Court and Riverdale Court using the same Arts and Crafts stylistic elements that adorned the houses in Wychwood Park. These initiatives located a settler future within the physical spaces of the city, symbolically signaling the end of colonial life and the advent of a national future.

\section{Conclusion}

As Baldwin has argued, Canada's national symbolic order is held in place by an imagined geography that associates whiteness with nature and racialization with urbanity. Within this symbolic order, white subjects secure their legitimacy within the national story by signaling a national beginning - literally creating a national future out of a seemingly empty space. By contrast, those racialized as other become cast as latecomers to the national story - crowding pre-existing cities and requiring instruction and governance in order to self-actualize. This symbolic order legitimizes white subjects as always already belonging in Canadian territory, as it continually reinforces the idea that nonwhite subjects are permanent outsiders. In this chapter, I have argued that Wychwood Park is situated as white space within the national imagination through its relationship to Toronto's downtown core. Calls for urban beautification advocated for increased park space, access to art, and single-family housing in an effort to raise the moral character of immigrant communities living in poverty. In order to civilize urban working classes, 
social reformers recommended that inner-city neighbourhoods more closely resemble what would become Wychwood Park.

As I have argued, programs designed to instruct immigrants on how to live - what art to value, how to clean and decorate their homes, where to spend leisure time constitute what Hage has called white governmental power. White governmental power, for Hage, places others within the spatiotemporal narrative of the nation. ${ }^{82}$ The programs that I have discussed in this chapter were designed to create of non-Anglo immigrants assimilated Canadian nationals. The aesthetic expertise and labour of early Wychwood residents were mobilized to refine urban spaces to achieve goals central to the settler colonial project of transcendence. Early Wychwood residents were participants in movements that argued for the aestheticization of urban environments as a requisite for national development. Just as these initiatives situated inner-city residents as culturally backwards and in need of improvement, future Wychwood Park residents were positioned as cultural leaders and specialists in creating civilizing spaces.

Wychwood Park was designed and developed amidst calls for environmental design to halt racial degeneration, to build a strong nation, and to prevent the "menace" that foreign enclaves posed to the future of Canada. The Park is a white settler colonial landscape because it functioned as an exemplary counterpoint to the racialized inner city. While Wychwood residents advised city planners on how to beautify the inner city, their own neighbourhood was resident-designed and resident-governed. Wychwood Park's landscape and architectural design were informed by the moral-aesthetic values of its residents, and those values included the use of environmental design to ensure settler

\footnotetext{
${ }^{82}$ Ghassan Hage, White Nation: Fantasies of White Supremacy in a Multicultural Society (New York: Routledge, 2000).
} 
colonial futurity. White space, reflected in Wychwood Park's design, signals colonial transcendence, because the Canadian national myth exalts the environmental labour and naturalized belonging of white subjects. 


\section{Conclusion}

"Your writing reads as if it's been written by an offended virgin, surveying the field of Canadian Art History shocked and appalled at every turn that the field doesn't mention settler colonialism. But why would it? Settler colonialism has nothing to do with Canadian art."

Peer reviewer, on text that became included in my Introduction

The document you have just read is the seventh draft of this dissertation, written for my third committee. The ideas I have explored here have been met with institutional resistance I did not anticipate. It was not until a peer reviewer commented with the feedback I quote above that I was able to clearly assess that the endless requests for further edits were no longer a reflection of the quality of my writing, but rather the lengths to which hegemonic power will go to protect epistemic conventions. When my reviewer called me an offended virgin for engaging in a critical literature review, s/he set up a discursive trap; I could hardly get angry or offended without proving their case.

The reviewer's critique revealed how invested patriarchal power is in maintaining research environments that deny the complex ways in which settler colonial power operates. My reviewer's sexism served the interests of settler colonial power by discouraging the pursuit of critical research. The disciplinary conventions in fields of research that seldom discuss settler colonial power are marked by patriarchal ontologies that sustain themselves by claiming critical interventions are illegitimate.

Describing me as an offended virgin for pursuing a gap in the field of Canadian Art History dismissed the legitimacy of my arguments by invoking the gendered trope of the hysterical virgin - naïve, not to be taken seriously, and requiring corrective treatment. Virgin, of course, is laden with many connotations. The myth of terra nullius imagined 
North America to be 'virgin' territory - available for colonial exploit. Virgin is a category applied to objects that subjects render productive or meaningful. It is also a temporal term. Virgin as untouched, undeveloped, and uncivilized invokes its various antonyms: advanced, developed, civilized, and rational. These binaries lie at the heart of western intellectual traditions, and are used to code differences of race, class, and gender. As Johannes Fabian has argued, western intellectuals organize their disciplines around an imagined distinction between western elites and those they exclude, such as women, nonwhite 'races', and working classes. Fabian's term "the denial of coevalness"1 describes how western elites envision themselves as occupying a different temporal category from those deemed 'other'. In the western intellectual imagination, authorized knowers are considered to be advanced/sophisticated/rational/civilized, while 'others' remain backwards/ignorant/uncivilized/virginal. My entrance into the realm of authorized knowers was blocked by invoking imperialism's binary logic; examining settler colonialism was too irrational a premise to be considered legitimate.

Wychwood Park's relationship to settler colonialism is a relationship that is consistently denied by the most culturally legitimized storytellers and knowledge keepers. In fact, when gender is recuperated as a focal point of critical engagement with the Wychwood Park story, it is done so at the cost of an analysis of settler colonial power.

On June 19, 2020, CBC radio's The Sunday Edition featured a documentary about Mary Hiester Reid. "She disappeared for nearly a century," the short article accompanying the audio file asserted, "and now she's back". ${ }^{2}$ Celebrated as "one of the

\footnotetext{
${ }^{1}$ Johannes Fabian, Time and the Other: How Anthropology Makes its Other (New York: Columbia University Press, 1983).

${ }^{2}$ Siegel, Alisa. "'Remember me as an artist': The rediscovery of Canadian painter Mary Hiester Reid." $C B C$ Radio: The Sunday Edition. https://www.cbc.ca/radio/thesundayedition/the-sunday-edition-for-june-21-
} 
most prolific and well-known artists of her generation", the documentary bemoaned the fact that Hiester Reid "is yet another case of the frequently told story of a woman artist who has simply been neglected and shoved to the sidelines and pushed out of popular consciousness. Someone who had a major career, who mattered, who was important, and who immediately after her death disappeared." ${ }^{\prime 3}$ As a matter of restoring her legacy within the canon of Canadian art and culture, the documentary featured interviews from many experts on Hiester Reid's life, including Molly Peacock, a writer whose biography of Hiester Reid will be released in 2021 - the centennial of her death. Also in 2021, the AGO will host an exhibition of Hiester Reid's life and work, intensifying the cultural attention to her life and work and elevating the timeliness of Peacock's biography of the artist.

The portrayal of Hiester Reid in the radio documentary, Peacock's biography, and the AGO's impending show situates the early Wychwood Park resident as a symbol of who official histories often forget. The exclusion of Hiester Reid from chronologies of Canadian Art History is framed as a wrong that contemporary interest in the artist can remedy. One of the reasons that the exclusion of Hiester Reid from conventional cultural histories is argued to be so unfair is that she deserved more attention based on her talent and contributions. However, the criteria used to reclaim Hiester Reid reinforces settler colonial institutions and cultural production. By restoring the legacy of Hiester Reid, $\mathrm{CBC}$ listeners were invited to continue taking for granted the ubiquity of settler colonial cultural institutions, the formalized timeline of Canadian Art History, and androcentric

2020-1.5612439/remember-me-as-an-artist-the-rediscovery-of-canadian-painter-mary-hiester-reid1.5612440

${ }^{3}$ Brian Foss, quoted in Siegel, "Remember me." 
models of labour and careerism. By this logic, Hiester Reid deserved more recognition, not because the metrics of recognition were flawed, but simply because she had been overlooked by those doing the recognizing.

Hiester Reid stands out in the historical narrative as exceptional - one of Canada's first professional women artists - and the CBC's audience was encouraged to admire and identify with. "This is the story of a woman ahead of her time. A woman who negotiated a marriage and a career - who kept her name, her identity, and her profession. Someone who paved the way for generations of artists," the narrator stressed. The documentary concluded with the following reflection by Peacock: "There is a way in which I have an urge to bring her into the 21 st century and say, 'See, this is how women live now. And you are one of the reasons that we can live the way we do.' Her life speaks to our lives. And through her, we can know the joy of reaching back into the past and feeling a hand grip ours in a way that says, 'I was alive. And you are too."”4

Settler colonialism was not mentioned once in the radio documentary, and there is no sign that the AGO or Peacock's book will contextualize Hiester Reid's life and work with a critical orientation towards the settler colonial violence at stake in Canadian nation-building. To do so would disrupt the premise of the documentary's focus. If settler colonialism were to enter the story of Hiester Reid, listeners would necessarily be invited to adopt a decidedly intersectional understanding of the artist, her context, her labour, and her legacy.

Certainly, her exclusion from history books reveals the fault lines of patriarchal logic - it is hard to argue that a white man who achieved her level of professional success

\footnotetext{
${ }^{4}$ Siegel, "Remember me."
} 
would have been similarly forgotten by historians (Marmaduke Matthews, for instance, was far less impressive). Given that Hiester Reid did achieve recognition during her lifetime, and given that it was rare (though not impossible) for women to be working as professional artists at the turn of the twentieth century, it seems a critical analysis of settler colonialism could be included in efforts to broaden the scope of understanding of her life and work. For instance, in what ways was Hiester Reid perceived of as a white (and therefore legitimate) cultural figure? Was she read as German, English, American, or Canadian within her lifetime, and how did these shifting categories of ethnicity, nation, and belonging inform the constrained choices she made in her life and in her artistic practice? What did it mean for an American artist, trained in Europe, to marry a Canadian farmboy-turned-artist and move to Canada's second largest city? What was her relationship to the land, and in what ways did the scenes she paint engage with the expansion of the settler colonial state within her lifetime? Did she have relationships with Indigenous communities? To what extent did she understand the socio-economic status of Indigenous people in Canada, and the legal status of the land on which she practiced? What role did geo-national borders and boundaries play in her sense of the world and the possibilities within it? Was Wychwood Park, as decorating magazines often proclaim, a piece of England in Canada for Hiester Reid, or something else?

The sentiment expressed in "you are one of the reasons that we can live the way we do" is revealing about the ways settler colonial social values express themselves. It is not (only) that contemporary women artists can look to Hiester Reid as their precedent, but that so long as figures like Hiester Reid are considered to be the only missing pieces of an otherwise inclusive historical narrative, settler colonialism will continue to be 
naturalized as an unspoken norm. If settler colonial power operates, to reiterate Rinaldo Walcott, by "producing what can too easily appear to be non-relational dynamics," then the memorializing of Hiester Reid's artistic work without mention of settler colonialism should serve as an index of settler colonial sensibility.

CBC Radio's documentary framed Hiester Reid's life - and by extension, the neighbourhood she helped animate - as important to progressive Canadian history. The portrayal of Hiester Reid on The Sunday Edition was framed as counter-hegemonic centering a figure who had been "pushed out of popular consciousness'." By characterizing Hiester Reid as ahead of her time, as paving the way for women after her, CBC's documentary reproduced a convention in the public storytelling of Wychwood Park's early residents. Wychwood Park, and its early residents, are storied as forebears of socially progressive values, institutions, and aesthetics. The $\mathrm{CBC}$ radio documentary directly appealed to those seeking to engage in critical, feminist, and more inclusive histories. In this way, the legacy of early Wychwood residents, and the public memory of the Park, appeal to sensibilities across the political spectrum. Progressive storytelling is used to characterize the Park as unidimensional, as opposed to embedded in the contradictions and nuances of settler colonial power.

The narrative of Wychwood Park as a progressive place - a neighbourhood with architecture modelled off of the socialist Arts and Crafts Movement, gardens and driveways embodying design principles of the quasi-communist Garden City Movement, famed early residents credited with democratizing the arts in Canada - is so widely accepted that a critical analysis of its relationship to settler colonialism is easily dismissed

\footnotetext{
${ }^{5}$ Rinaldo Walcott, "Foreword," in Critical Inquiries: A Reader in Studies of Canada, ed. Lynn Caldwell, Darryl Leroux, and Carianne Leung (Halifax: Fernwood, 2013), 4.
} 
as misplaced. Throughout my research and writing process, I encountered multiple forms of institutional resistance to my research questions and early conclusions - not only from the archives, but from leading academic studies about the Park and peer reviewers of my early work. Categorically, settler colonialism is widely considered to be so unrelated to Wychwood Park that its mere mention can be quickly rejected as unconnected. In the Land Records Office, I was informed that my research question was irrelevant. A peer reviewer informed me that settler colonialism has "nothing" to do with Canadian art. The blunt nature of these comments reflect how successfully settler colonial power has been reproduced as non-relational. The denial of settler colonialism as a dynamic of power in research environments functions to suppress any discussion, examination, or debate about the nature of settler colonialism at all. Rather than disagree with my approach, the institutionalized attitudes I have discussed simply refused to acknowledge the legitimacy of studying settler colonialism in contexts traditionally considered to be beyond the scope of settler colonialism's impact.

It was precisely because Wychwood Park is so beloved and often written about that I wanted to study its relationship to settler colonial power. The public narrative of the Park was so widely accepted and the physical landscaping and architecture often celebrated by progressives. I was interested in how and where settler colonial power operates when it appears to be irrelevant to the case study at hand. This was guided by my longstanding research interest in the social construction of whiteness, and how critical scholars have worked to identify a manifestation of social power defined by invisibility and denial. 
This dissertation has argued that there is not only a relationship between Wychwood Park and settler colonialism, but that the Park itself constitutes a white settler colonial landscape. By the phrase "white settler colonial landscape," I draw attention to the ways that scholars have argued that landscapes can be racialized, and that settler colonialism in Canada enacts racialized violence through the appropriation, commodification, occupation, and aestheticization of land.

My four analysis chapters offered a deepened discussion of the three primary themes I used to advance my argument, and this structure reflected the need for an organizational container for these ideas. This dissertation's structure distinguished Indigenous elimination, settler indigenization, and colonial transcendence from each other - though in truth these concepts are intersecting constantly as settler colonial society works to ensure its permanence. I used the theme of Indigenous elimination to situate Wychwood Park within the settler colonial land economy. Settler indigenization was the framework I relied on to explore how Wychwood Park as a landscape was embedded within settler colonial cultural systems. Finally, the racialization of Wychwood Park as white was an idea I developed within the understanding of colonial transcendence. My argument is informed by the fact that settler colonialism is not mentioned in existing studies of the Park. Further, settler colonial studies scholars have argued convincingly that the active denial of settler colonialism's continued scope is one of the ways hierarchies reproduce their power. Therefore, in order to destabilize settler colonial logics, I have advanced my argument that Wychwood Park is related to settler colonialism, drawing an explicit link between settler colonialism as a system of power and Wychwood Park as an object of study. 
First, I have demonstrated how the creation of Wychwood Park through the subdivision of privately held land is situated within an economic system of land commodification and exchange that has been central to the settler colonial economy in Ontario for the past two hundred years. Beginning in the late eighteenth century, British officials negotiated land cessions in the Toronto area with the Mississaugas of the Credit River for less than market value. Land was then granted for free to settlers. Colonial law forbid Indigenous people from selling their land directly to settlers, and as the market for land increased with massive waves of immigration, settlers were able to subdivide their land for increasing profits. Therefore, the commodification of land has not only been profitable for settlers, but it has established an economic system of land exchange premised upon Indigenous exclusion. Wychwood Park is related to the political economy of settler colonialism by virtue of being a gated community of privately held homes. settler colonial studies scholars have argued that the establishment of private property was one of many ways in which settler colonial governments worked to "eliminate" Indigenous political power.

Second, I have illustrated how the landscape and architectural design of the Park successfully evoke a sense of Britishness in midtown Toronto. I have argued that the naturalization of British culture in the Toronto landscape is enacted through processes of de-territorializing the Park of its Indigenous land use and meaning, and re-territorializing it as British space. Through this process, British cultural referents such as Arts and Crafts architecture and garden suburb landscape design appear so normal that they become “indigenized" to the region. Wychwood Park's design is related to settler colonialism because it simultaneously codes Toronto as British territory, thereby undermining 
Indigenous land claim and territorial meaning. Battell Lowman and Barker have referred to efforts such as these as part of a process of "settler indigenization.",6

A second process by which Wychwood Park reflects settler colonial society's efforts at indigenization is through the discourse of public heritage. Public heritage imagines the national community as cultural kin who share common ancestors. George A. Reid's pioneer murals promoted the idea of settler labour transforming the Canadian wilderness into the site of a productive agricultural economy. Reid's scenes of pioneer labour celebrated the role of settler pioneers as national ancestors, promoting an origin myth for Canada premised upon the labour of industrious settlers. As a heritagedesignated district, Wychwood Park is storied as a site whose history belongs to all Canadians. In this way, the Park's history is used to promote the idea that settler colonial society belongs in North American territory. Through the language of public heritage, the landscape of Wychwood Park is animated as a source of settler colonial identification and inter-generational belonging.

Finally, this dissertation has argued that Wychwood Park is white space, by virtue of the fact that it is imagined to be civilized and ideal as opposed to the inner-city districts associated with filth, overcrowding, and non-Anglo residents requiring assistance. I have argued that Wychwood Park residents contributed to urban beautification initiatives in the early twentieth century that were designed to re-shape Toronto to be a city capable of creating model (white) national citizens. Urban beautification was undertaken in order to strengthen the Canadian national citizenry, thereby ensuring the long-term success of settler colonial society. As Lowman and Barker have argued, one of settler colonialism's

\footnotetext{
${ }^{6}$ Battell Lowman, Emma, and Adam J. Barker. Settler Identity and Colonialism in 21st Century Canada (Halifax: Fernwood, 2015).
} 
goals is the creation of a settler society that fully replaces Indigenous society, thereby transcending Indigenous sovereignty. The civic contributions undertaken by Wychwood residents are related to settler colonialism because they contributed to the goal of settler transcendence.

Earlier in this chapter, I referenced a recent CBC Radio documentary about Mary Hiester Reid. I did so in order to illustrate how often Wychwood Park and its early residents continue to be discussed in popular media bereft of any mention of settler colonialism. It is not within the scope of this dissertation to begin answering the questions I asked of future research into Hiester Reid's life and work. It is my hope that the impact of research such as this will be to offer a model of how to integrate an analysis of settler colonialism into studies and cultural conversations that appear (to some) to have nothing to do with settler colonialism. My interest in drawing links where none existed already was surprisingly threatening to established voices in the various fields of research that have studied Wychwood Park most extensively. Future scholarship into the construction of settler colonial ways of knowing will necessarily need to contest the terms in which "legitimacy" has been guarded. 


\section{Bibliography}

Adams, Annmarie. "Eden Smith and the Canadian Domestic Revival." Urban History Review 21, no. 2 (1993): 104-15.

Ahmed, Sara. "Declarations of Whiteness: The Non-Performativity of Anti-Racism." borderlands e-journal 3, no. 2 (2004).

Alfred, Taiaiake and Jeff Corntassel. "Being Indigenous: Resurgences Against Contemporary Colonialism” Government and Opposition 40, no. 4 (2005): $597-$ 614.

Allen, Theodore. The Invention of the White Race. London: Verso, 1994.

Avery, Simon. “The Wychwood Park Mystery.” Globe and Mail, May 16, 2003.

Bacchi, Carol. "Race Regeneration and Social Purity: A Study of the Social Attitudes of Canada's English-Speaking Suffragists.” In Interpreting Canada's Past: Volume II, After Confederation, 2nd ed., edited by J.M. Bumstead, 237-53. Toronto: Oxford University Press, 1993.

Baldwin, Andrew. "Ethnoscaping Canada's Boreal Forest: Liberal Whiteness and its Disaffiliation from Colonial Space.” The Canadian Geographer 53 (2009): 42743.

- "The White Geography of Lauren Stewart Harris: Whiteness and the Performative Coupling of Wilderness and Multiculturalism in Canada." Environment and Planning 41 (2009): 529-44.

—. "Whiteness and Futurity: Towards a Research Agenda." Progress in Human Geography 36 (2012): 172-87.

—. "Wilderness and Tolerance in Flora MacDonald Denison: Towards a Biopolitics of Whiteness." Social and Cultural Geography 11 (2010): 883-901.

Baldwin, Andrew, Laura Cameron, and Audrey Kobayashi. Rethinking the Great White North: Race, Nature, and the Historical Geographies of Whiteness in Canada. Vancouver: UBC Press, 2011.

Baloy, N.J.K. "Spectacles and Spectres: Settler Colonial Spaces in Vancouver." Settler Colonial Studies 6, no. 3 (2016): 209-34.

Banivanua Mar, Tracey, and Penelope Edmonds, eds. Making Settler Colonial Space: Perspectives on Race, Place, and Identity. London: Palgrave Macmillan, 2010. 
Bannerji, Himani. The Dark Side of the Nation: Essays on Multiculturalism, Nationalism, and Gender. Toronto: Canadian Scholars Press, 2000.

_ . "Geography Lessons: On Being an Insider/Outsider to the Canadian Nation." In Unhomely States: Theorizing English Canadian Postcolonialism, edited by Cynthia Sugars, 289-300. Toronto: Broadview Press, 2004.

Battell Lowman, Emma, and Adam J. Barker. Settler Identity and Colonialism in 21st Century Canada. Halifax: Fernwood, 2015.

Belich, James. Replenishing the Earth: The Settler Revolution and the Rise of the Angloworld. Oxford: Oxford University Press, 2009.

Belton, Robert James. Sights of Resistance: Approaches to Canadian Visual Culture. Calgary: University of Calgary Press, 2001.

Blomley, Nicholas. "Law, Property and the Geography of Violence: The Frontier, The Survey, and the Grid." Annals of the Association of American Geographers 93, no. 1 (2003): 121-41.

- Unsettling the City: Urban Land and the Politics of Property. New York: Routledge, 2004.

Bobiwash, Rodney. "The History of Native People in the Toronto Area." In The Meeting Place: Aboriginal Life in Toronto, edited by Frances Sanderson and Heather Howard-Bobiwash, 5-24. Toronto: Native Canadian Centre of Toronto, 1997.

Bonds, Anne, and Joshua Inwood. "Beyond White Privilege: Geographies of White Supremacy and Settler Colonialism." Progress in Human Geography 40, no. 6 (2016): 715-33.

Boyanoski, Christine. "Artists, Architects \& Artisans At Home." In Artists, Architects, Artisans: Canadian Art 1890-1918, edited by Charles Hill, 88-109. Ottawa: National Gallery of Canada, 2013.

- Sympathetic Realism: George A. Reid and the Academic Tradition. Toronto: Art Gallery of Ontario, 1986.

Braun, Brian. "On the Raggedy Edge of Risk: Articulations of Race and Nature." In Race, Nature, and the Politics of Difference, edited by Donald S. Moore, Jake Kosec, and Anand Pandian, 175-203. Durham, NC: Duke University Press, 2003.

Brown, W. Douglas. "The Arts and Crafts Architecture of Eden Smith." The Journal of Pre-Raphaelite Studies 6/7 (Fall-Spring 1997-8): 147-60. 
—. Toronto Architect Eden Smith: His Buildings and Clients. Self-published, Mississauga, updated May 2006.

- Toronto Architect Eden Smith: Toronto's Arts and Crafts Architect. Selfpublished, Mississauga, 2003.

Callen, Anthea. "Sexual Division of Labor in the Arts and Crafts Movement." Woman's Art Journal 5, no. 2 (1984): 1-6.

Canada, Indian Treaties and Surrenders, from 1680-1890. 2 vols. Ottawa, Brown Chamberlin, 1891; reprint, Saskatoon: Fifth House Publishers, 1992.

Carter, Sarah. Lost Harvests: Prairie Indian Reserve Farmers and Government Policy. Montreal: McGill-Queens University Press, 2019.

Chamberlin, Edward, and Sander L. Gilman. Degeneration: The Dark Side of Progress. New York: Columbia University Press, 1985.

Chan, Arlene. "Against All Odds: The Chinese Laundry." In The Ward: The Life and Loss of Toronto's First Immigrant Neighbourhood, ed. John Lorinc, Michael McLellan, and Ellen Scheinberg, 39-43. Toronto: Coach House Books, 2015.

Coleman, Daniel. White Civility: The Literary Project of English Canada. Toronto: University of Toronto Press, 2006.

Cosgrove, Denis. "Prospect, Perspective, and the Evolution of the Landscape Idea." Transactions of the Institute of British Geographers 10, no. 1 (1985): 45-62.

Coulthard, Glen. Red Skin, White Masks: Rejecting the Colonial Politics of Recognition. Minneapolis: University of Minnesota Press, 2014.

Coutts, Ian. "Lost Rivers: Storm Sewers Swallowed Many of the Streams and Brooks that Once Meandered through Our Cities. Now, a New Movement Is Aiming to 'Daylight' those Forgotten Watercourses." Canadian Geographic 122, no. 3 (May, 2002), 64.

Cruikshank, E.A., ed. The Simcoe Papers. 5 volumes. Toronto: Ontario Historical Society, 1924.

Currelly, Charles. I Brought the Ages Home. Toronto: Ryerson Press, 1956.

Cvetkovich, Ann. An Archive of Feelings: Trauma, Sexuality, and Lesbian Public Cultures. Durham, NC: Duke University Press, 2003.

Daschuk, James. Clearing the Plains: Disease, Politics of Starvation, and the Loss of Aboriginal Life. Regina: University of Regina Press, 2013. 
Day, Richard. Multiculturalism and the History of Canadian Diversity. Toronto: University of Toronto Press, 2000.

Dickman, Chris. G.A. Reid: Toward a Union of the Arts. Exhibition catalogue. Durham, ON: Durham Art Gallery, 1985.

Dorries, Heather. "Planning as Property: Uncovering the Hidden Racial Logic of a Municipal Nuisance By-Law." Journal of Law and Social Policy 27 (2017): 7293.

Douglas, Ann. The Feminization of American Culture. New York: Avon Books, 1978.

Dua, Enakshi, and Angela Robertson, eds. Scratching the Surface: Canadian Anti-Racist Feminist Thought. Toronto: Canadian Scholars Press, 1999.

Dyer, Richard. White: Essays on Race and Culture. New York: Routledge, 1997.

Edmonds, Penelope. “Unpacking Settler Colonialism's Urban Strategies: Indigenous Peoples in Victoria, British Columbia and the Transition to a Settler Colonial City." Urban History Review/Revue d'histoire urbaine 38, no. 2 (2010): 4-20.

Elkins, Caroline, and Susan Pedersen, eds. Settler Colonialism in the Twentieth Century. New York: Routledge, 2005.

Fabian, Johannes. Time and the Other: How Anthropology Makes Its Object. New York: Columbia University Press, 1983.

Fanon, Frantz. Black Skin White Masks. Translated by Richard Philcox. New York: Grove Press, 2008.

Foss, Brian, and Janice Anderson, eds. Quiet Harmony: The Art of Mary Hiester Reid. Toronto: Art Gallery of Ontario, 2000.

Firth, Edith. The Town of York 1793-1815. Toronto: Champlain Society, 1962.

Frankenberg, Ruth. White Women, Race Matters: The Social Construction of Whiteness. Minneapolis: University of Minnesota Press, 1993.

Freeman, Elizabeth. Time Binds: Queer Temporalities, Queer Histories. Durham, NC: Duke University Press, 2010.

Freeman, Victoria J. “"Toronto Has No History!': Indigeneity, Settler Colonialism, and Historical Memory in Canada's Largest City." PhD dissertation, University of Toronto, 2010. 
Furniss, Elizabeth. The Burden of History: Colonialism and the Frontier Myth in a Rural Canadian Community. Vancouver: UBC Press, 1999.

Gates, Lillian. Land Policies of Upper Canada. Toronto: University of Toronto Press, 1968.

Goldberg, David Theo. Racist Culture: Philosophy and the Politics of Meaning. Oxford: Blackwell, 1993.

Goheen, Peter. Victorian Toronto: 1850 to 1900. Toronto: Committee on Geographical Studies, 1970.

Goldman, Marlene. DisPossession: Haunting in Canadian Fiction. Montreal: McGillQueens University Press, 2012.

Hage, Ghassan. White Nation: Fantasies of White Supremacy in a Multicultural Society. New York: Routledge, 2000.

Haig-Brown, Celia. "Decolonizing Diaspora: Whose Traditional Land Are We On?" Cultural and Pedagogical Inquiry 1, no. 2 (2009): 1-21.

Hall, Stuart. "Gramsci's Relevance for the Study of Race and Ethnicity." Journal of Communication Inquiry 10, no. 2 (1986): 5-27

Hardesty, Nancy. Women Called to Witness: Evangelical Feminism in The Nineteenth Century. Nashville: Abingdon Press, 1984.

Henderson, Jennifer. Settler Feminism and Race Making in Canada. Toronto: University of Toronto Press, 2003.

Hill, Charles C., ed. Artists, Architects, \& Artisans: Canadian Art 1890-1918. Ottawa: National Gallery of Canada, 2013.

Hill, Charles C. "For an Integration of the Arts." In Artists, Architects, \& Artisans: Canadian Art 1890-1918, edited by Charles C. Hill. Ottawa: National Gallery of Canada, 2013.

Hill, Mike, ed. Whiteness: A Critical Reader. New York: NYU Press, 1997.

Hill Collins, Patricia. Black Feminist Thought: Knowledge, Consciousness, and the Politics of Empowerment. New York: Routledge, 2000.

hooks, bell. Feminist Theory from Margin to Center. Boston: South End Press, 1984.

Hubbard, Edward, and Michael Shippobottom. A Guide to Port Sunlight Village. Liverpool: Liverpool University Press. 
Hughes, J.H., and E. Foster, eds. The Dominion Educator. 8 volumes. Toronto: Peace Edition, 1919.

Hugill, David. "Metropolitan Transformation and the Colonial Relation: The Making of an 'Indian Neighbourhood' in Postwar Minneapolis." Middle West Review 2, no. 2 (2016): 169-200

_. "Settler Colonial Urbanism: Notes from Minneapolis and the Life of Thomas Barlow Walker." Settler Colonial Studies 6, no. 3 (2016): 265-78.

—_."What Is a Settler Colonial City." Geography Compass 11, no. 5 (2017): 1-11.

Hugill, David, and Owen Toews. "Born Again Urbanism: New Missionary Incursions, Aboriginal Resistance and Barriers to Rebuilding Relationships in Winnipeg's North End.” Human Geography 7, no. 1 (2014): 69-83.

Ignatiev, Noel, and John Garvey, eds. Race Traitor. New York: Routledge, 1996.

Jacobs, Sidney. "Race, Empire, and the Welfare State: Council Housing and Racism." Critical Social Policy 5, no. 13 (1985): 6-28

Jamoussi, Zouheir. Primogeniture and Entail in England: A Survey of Their History and Representation in Literature. Cambridge: Cambridge Scholars Press, 2011.

Johnson, Leo. "The Mississauga-Lake Ontario Land Surrender of 180." Ontario History 83, no. 3 (1990): 233-53.

“In the Studios of Toronto’s Best Known Artists." Toronto Sunday World, April 2, 1911.

Johnston, Charles M. The Valley of the Six Nations. Toronto: Champlain Society, 1964.

Johnston, Darlene. "Connecting People to Place: Great Lakes Aboriginal History in Cultural Context." Report prepared for the Ipperwash Commission of the Inquiry, August 2004.

https://www.attorneygeneral.jus.gov.on.ca/inquiries/ipperwash/transcripts/pdf/P1 Tab_1.pdf

Jones, Hugh, in collaboration with Edmund Dyonnet. History of the Royal Canadian Academy of Arts. Self-published, Toronto, 1934. Available at http://rca-arc.ca/wpcontent/uploads/2013/12/R.C.pdf

Killan, Gerald. Preserving Ontario's Heritage: A History of the Ontario Historical Society. Toronto: Ontario Historical Society, 1976. 
Knowles, Norman. Inventing the Loyalists: The Ontario Loyalist Tradition and the Creation of Usable Pasts. Toronto: University of Toronto Press, 1997.

Kobayashi, Audrey, and Linda Peake. "Racism Out of Place: Thoughts on Whiteness and an Antiracist Geography in the New Millennium." Annals of the Association of American Geographers 90, no. 2 (2000): 392-403.

Kosek, Jake. "Purity and Pollution: Racial Degradation and Environmental Anxieties." In Liberation Ecologies: Environment, Development and Social Movements, edited by Richard Peet and Michael Watts, 125-54. London: Routledge, 1996.

Latham, David, ed. Scarlet Hunters: Pre-Raphaelitism in Canada. Toronto: Archives of Canadian Art and Design, 1998.

Lawrence, Bonita. "Real” Indians and Others: Mixed-Blood Urban Native Peoples and Indigenous Nationhood. Lincoln: University of Nebraska Press, 2004.

Lerner, Loren. "Canada Receiving the Homage of Her Children: George Reid's Ave Canada and Gustav Hahn's Hail Dominion: A Proposal of Murals for the Entrance Hall of Canada's Parliament Buildings." Journal of Canadian Art History 29, no. 1 (2008): 50-86.

—. "George Reid's Paintings as Narratives of a Child Nation.” In Depicting Canada's Children, edited by Loren Lerner, 325-46. Waterloo, ON: Wilfred Laurier University Press, 2009.

Livesay, Graham. "Assemblage Theory, Gardens and the Legacy of the Early Garden City Movement." Arq: Architectural Research Quarterly 15, no. 3 (2011): 271-8.

Lochnan, Katharine A., Douglas E. Schoenherr, and Carole Silver, eds. The Earthly Paradise: Arts and Crafts by William Morris and His Circle from Canadian Collections. Toronto: Art Gallery of Ontario, 1993.

Loomba, Ania. Colonialism/Postcolonialism. London: Routledge, 1998.

Lorde, Audre. Sister Outsider: Essays and Speeches. Freedom, CA: Crossing Press, 1984.

MacDougall, Heather A. "The Genesis of Public Health Reform in Toronto, 1869-1890." Urban History Review 10, no. 3 (February 1982): 1-10.

Mackey, Eva. Unsettled Expectations: Uncertainty, Land, and Settler Decolonization. Halifax: Fernwood, 2016.

Mackintosh, Phillip G. “'The Development of Higher Urban Life' and the Geographic Imagination: Beauty, Art, and Moral Environmentalism in Toronto, 1900-1920.” Journal of Historical Geography 31, no. 4 (2005): 688-722. 
- "Imagination and the Modern City: Reform and the Urban Geography of Toronto, 1890-1929." PhD dissertation, Queens University, 2001.

- "The Occult Relation Between Man and the Vegetable: Transcendentalism, Immigrants, and Park Planning in Toronto, circa 1900," in Rethinking the Great White North: Race, Nature, and the Historical Geographies of Whiteness in Canada, ed. Andrew Baldwin, Laura Cameron, and Audrey Kobayashi, 85-106. Vancouver: UBC Press, 2011.

Margaret McBurney, The Great Adventure: 100 Years at the Arts and Letters Club. Toronto: Arts and Letters Club, 2007.

McClintock, Anne. Imperial Leather: Race, Gender, and Sexuality in the Colonial Contest. New York: Routledge, 1995.

McCullagh, John. A Legacy of Caring: A History of the Children's Aid Society of Toronto. Toronto: Dundurn Press, 2002.

McLean, Sheelah. "The Whiteness of Green: Racialization and Environmental Education." The Canadian Geographer 57, no. 3 (2013): 354-62.

McLeod, D. Peter. "Anishinabeg Point of View: The History of the Great Lakes Region to 1800 in Nineteenth-Century Mississauga, Odawa and Ojibwa Historiography." Canadian Historical Review 73, no. 2 (1992): 194-210.

McLeod, Ellen. In Good Hands: The Women of the Canadian Handicrafts Guild. Montreal: McGill University Press, 1999.

Merriman, Brenda. Genealogy in Ontario: Searching the Records. Toronto: Ontario Genealogical Society, 2013.

Meyer, Marc. "Preface." In Artists, Architects, Artisans: Canadian Art 1890-1918, edited by Charles Hill, 7. Ottawa: National Gallery of Canada, 2013.

Miller, Keith. The History and Development of Wychwood Park 1888-1918. Selfpublished, Toronto, 1981.

Miller, Keith, and Albert Fulton. The Art of Wychwood: Catalogue of the Art on Display During the Joy of Wychwood Centennial Exhibition. Toronto: Wychwood Park Archives, 1988.

Miner, Muriel Miller. G.A. Reid, Canadian Artist. Toronto: Ryerson Press, 1946. Republished as: George Reid: A Biography. Toronto: Summerhill Press, 1987.

Mitchell, W.J.T., ed. Landscape and Power. Chicago: University of Chicago Press, 1994. 
Moreton Robinson, Aileen. Talkin' Up to the White Woman: Aboriginal Women and Feminism. St. Lucia: University of Queensland Press, 2002.

Murphyao, Amanda, and Kelly Black. "Unsettling Settler Belonging: (Re)naming and Territory Making in the Pacific Northwest." American Review of Canadian Studies 45 (2015): 315-31.

Murray, Joan. Ontario Society of Artists: 100 Years. Toronto: Art Gallery of Ontario, 1972.

Mutua, Kagendo, and Beth Blue Swadener. Decolonizing Research in Cross-Cultural Contexts: Critical Personal Narratives. Albany: SUNY Press, 2004.

Neal, Carolyn. Eden Smith, Architect, 1858-1949: A Biography Prepared for the Architectural Conservancy of Ontario Toronto Region Branch. Toronto: The Conservancy, 1976.

Noble, Jean Bobby. Sons of the Movement: FtMs Risking Incoherence on a Post-Queer Cultural Landscape. Toronto: Canadian Scholars' Press, 2006.

Olivero, Simone. "House of the Week: \$5.5 Million for a Wychwood Park Home with a Backyard Tennis Court." Toronto Life, June 26, 2013. https://torontolife.com/realestate/house-of-the-week-106-wychwood-park/

Panayotidis, E. Lisa. "The Complexity of 'Seeing' and Doing 'Good': A Canadian Art Education Analysis of the 'Good Society." Canadian Review of Art Education 29, no. 2 (2002): 1-18.

Pepall, Rosalind M. "The Murals by George A. Reid in the Toronto Municipal Buildings, 1897-1899.” Master's thesis, Concordia University, 1982.

Perry, Adele. On the Edge of Empire: Gender, Race, and the Making of British Columbia 1849-1871. Toronto: University of Toronto Press, 2001.

Phillips, Ruth. Trading Identities: The Souvenir in Native North American Art from the Northeast, 1700-1900. Montreal: McGill-Queen’s University Press, 1999.

Pollock, Griselda, and Rozsika Parker. Old Mistresses: Women, Art and Ideology. New York: Pandora Press, 1981.

Porter, Libby, and Oren Yiftachel, eds. "Settler Colonialism, Indigeneity, and the City." Special issue, Settler Colonial Studies 9, no. 2 (2019).

Purdie, James. "Toronto's Unique Private Enclave for 53 Families." Toronto Life, April 1970, 48-73. 
Purdy, Sean. "Housing Reform Thought in English Canada, 1900-1950.” Urban History Review 25, no. 2 (1997): 30-40.

Rankin, Jim. "Inside the Weird World of Wychwood Park." Toronto Star, December 21, 2012.

Rayburn, Alan. “The Real Story of How Toronto Got Its Name.” Canadian Geographic 114, no. 5 (1994): 68.

Razack, Sherene. Race, Space, and the Law: Unmapping a White Settler Society. Toronto: Between the Lines Press, 2002.

Regan, Paulette. Unsettling the Settler Within: Indian Residential Schools, Truth Telling, and Reconciliation in Canada. Vancouver: UBC Press, 2011.

Reid, Dennis. "Our Own Country Canada”: Being an Account of the National Aspirations of the Principal Landscape Artists in Montreal and Toronto, 18601890. Ottawa: National Gallery of Canada, 1978.

Rifkin, Mark. Settler Common Sense: Queerness and Everyday Colonialism in the American Renaissance. Minneapolis: University of Minnesota Press, 2014.

Robinson, Percy. "The Chevalier de Rocheblave and the Toronto Purchase." Royal Society of Canada Transactions 31, third series (1937): 131-52.

_. "The Toronto Carrying Place and the Toronto Purchase." Ontario History 34 (1947): 41-9.

- Toronto During the French Regime, 1615-1793. Toronto: University of Toronto Press, 1965.

Roediger, David. The Wages of Whiteness: Race and the Making of the American Working Class. London: Verso, 1999.

Rose, Nikolas, and Peter Miller. "Political Power Beyond the State: Problematics of Government." The British Journal of Sociology 61, no. 1 (2010): 271-303.

“Royal Proclamation of 1763." Canada Watch (Fall 2013): 14-15.

Ryan, Mary. “Gender and Public Access: Women's Politics in Nineteenth-Century America." In Habermas and the Public Sphere, edited by Craig Calhoun, 259-88. Cambridge MA: MIT Press, 1992.

—. Women in Public. Baltimore: Johns Hopkins University Press, 1990. 
Russell, Peter. The Correspondence of the Honourable Peter Russell With allied documents relating to his administration of the government of Upper Canada, during the official term of Lieutenant Governor J.G. Simcoe, while on leave of absence. 3 volumes. Toronto: Ontario Historical Society, 1932.

Said, Edward. Culture and Imperialism. New York: Vintage Books, 1993.

—. Orientalism. New York: Vintage Books, 1978.

Sandilands, Catriona. "Domestic Politics: Multiculturalism, Wilderness, and the Desire for Canada." Space and Culture 4 (1999): 169-86.

Schein, Richard. "A Methodological Framework for Interpreting Ordinary Landscapes: Lexington, Kentucky’s Courthouse Square.” Geographical Review 99, no. 3 (2009): $377-402$

- "The Place of Landscape: A Conceptual Framework for Interpreting an American Scene." Annals of the Association of American Geographers 87, no. 4 (1997): 660-80.

Schmalz, Peter. The Ojibwa of Southern Ontario. Toronto: University of Toronto Press, 1991.

School Art Leagues. Circular, 1899. Toronto: Toronto School Art Leagues.

Siegel, Alisa. “"Remember me as an artist': The rediscovery of Canadian painter Mary Hiester Reid." CBC Radio: The Sunday Edition. https://www.cbc.ca/radio/thesundayedition/the-sunday-edition-for-june-21-2020$1.5612439 /$ remember-me-as-an-artist-the-rediscovery-of-canadian-painter-maryhiester-reid-1.5612440

Simpson, Audra. Mohawk Interruptus: Political Life Across the Borders of Settler States. Durham: Duke University Press, 2014.

Sisler, Rebecca. Passionate Spirits: A History of the Royal Canadian Academy of Arts 1880-1980. Toronto: Clarke, Irwin, 1980.

Skinner, Damien. "Settler Colonial Art History: A Proposition in Two Parts." Journal of Canadian Art History/Annales d'histoire de l'art Canadien 35, no. 1 (2014): 13045, 157-75.

Smith, Donald B. "The Dispossession of the Mississauga Indians: a Missing Chapter in the Early History of Upper Canada." Ontario History 73, no. 2 (1981): 67-8.

Stansell, Christine. City of Women: Sex and Class in New York 1780-1860. Chicago: University of Illinois Press, 1987. 
Stasiulus, Daiva, and Radha Jhappan. "The Fractious Politics of a Settler Society: Canada." In Unsettling Settler Societies: Articulations of Gender, Race, Ethnicity and Class, edited by Daiva Stasiulus and Nora Yuval-Davis, 95-131. London: Sage, 1995.

Stasiulis, Daiva, and Nira Yuval-Davis, eds. Unsettling Settler Societies: Articulations of Gender, Race, Ethnicity, and Class. London: Sage, 1995.

Stoler, Ann Laura. Race and the Education of Desire: Foucault's History of Sexuality and the Colonial Order of Things. Durham, NC: Duke University Press, 1995.

Sugars, Cynthia. "Repetition with a Difference: The Paradox of Origins in Alistair MacLeod's No Great Mischief" Studies in Canadian Literature/Etudes en Literature Canadienne, 33 no. 2 (2008): 133-150.

Taylor, Alan. The Divided Ground: Indians, Settlers, and the Northern Borderland of the American Revolution. New York: Vintage Books, 2006.

Teasdale, Margot. "Preservation Planning with Conservation Districts with Special Reference to Wychwood Park, Toronto." Master's thesis, Faculty of Environmental Studies, York University, 1984.

Teather, Lynne. The Royal Ontario Museum: A Prehistory 1830-1914. Toronto: Canada University Press, 2005.

Thobani, Sunera. Exalted Subjects: Studies in the Making of Race and Nation in Canada. Toronto: University of Toronto Press, 2007.

Toews, Owen. Stolen City: Racial Capitalism and the Making of Winnipeg. Winnipeg: ARP Books, 2018.

Tomiak, Julie. "Contesting the Settler City: Indigenous Self-Determination, New Urban Reserves and the Neoliberalization of Colonialism." Antipode 49, no. 4 (2017): 928-45.

Tomko, Linda. Dancing Class: Gender, Ethnicity, and Social Divides in American Dance 1890-1920. Bloomington: Indiana University Press, 1999.

Tuck, Eve, and K. Wayne Yang. "Decolonization is Not A Metaphor." Decolonization: Indigeneity, Education \& Society 1, no. 1 (2012): 1-40.

Tuhiwai Smith, Linda. Decolonizing Methodologies: Research and Indigenous People. London: Zed Books, 1999. 
Valverde, Mariana. The Age of Light, Soap, and Water: Moral Reform in English Canada 1885-1925. Toronto: University of Toronto Press, 2008.

Veracini, Lorenzo. "Introducing Settler Colonial Studies." Settler Colonial Studies 1 (2011): 1-12.

—_. "On Settlerness." borderlands e-journal 10, no. 1 (2011): 1-17.

- Settler Colonialism: A Theoretical Overview. London: Palgrave MacMillan, 2010.

Vickery, Amanda. "Golden Age to Separate Spheres? A Review of the Categories and Chronology of English Women's History." The Historical Journal 36 (1993): 383-414.

Walcott, Rinaldo. Black Like Who? Writing Black Canada. Toronto: Insomniac Press, 1997.

—_. "Foreword." In Critical Inquiries: A Reader in Studies of Canada, edited by Lynn Caldwell, Darryl Leroux, and Carianne Leung, 4. Halifax: Fernwood, 2013.

Ware, Vron. Beyond the Pale: White Women, Racism, and History. London: Verso, 1992.

Weaver, Emily. "The Italians in Toronto." In The Ward: The Life and Loss of Toronto's First Immigrant Neighbourhood, ed. John Lorinc, Michael McLellan, and Ellen Scheinberg, 102-3. Toronto: Coach House Books, 2015.

White, Richard. The Middle Ground: Indians, Empires, and Republics in the Great Lakes Region, 1650-1815. Cambridge: Cambridge University Press, 2010.

Whiteson, Leon. "Wychwood Park: A Tranquil Retreat for a Metro Elite." Toronto Star, January 16, 1982.

William Morris Society of Canada Newsletter, Winter 1991-2.

Wilton, Elizabeth. “'Cloud-Bound': The Western Landscapes of Marmaduke Matthews." In A Few Acres of Snow: Literary and Artistic Images of Canada, edited by Paul Simpson-Housely and Glen Norcliffe, 235-42. Toronto: Dundurn Press, 1992.

Wolfe, Patrick. "Land, Labor, and Difference: Elementary Structures of Race," American Historical Review 106, (2001): 865-905.

—. "Settler Colonialism and the Elimination of the Native." Journal of Genocide Research 8, no. 4 (2006): 387-409. 
- Settler Colonialism and the Transformation of Anthropology. London: Bloomsbury, 1999.

"Wychwood Park: An Oasis of Green Among the Asphalt." Canada Home Décor, Summer 1979, 56-9.

Wychwood Park Heritage Conservation District Plan. Toronto: Toronto Historical Board, 1986. Wylie, John. Landscape. New York: Routledge, 2007.

Zueblin, Charles. A Decade of Civic Development. Chicago: University of Chicago Press, 1905.

\section{Archives Consulted}

Archives of Ontario

City of Toronto Archives

Library and Archives Canada

Toronto Land Records Office

Toronto Reference Library 